Szegedi Tudományegyetem

Gazdaságtudományi Kar

Közgazdaságtani Doktori Iskola

Imreh-Tóth Mónika

\title{
Egyetemek vállalkozásoktatásának lehetséges szerepe a vállalkozóvá válás elősegítésében
}

Doktori értekezés

Témavezetők:

Prof. Dr. Dinya László, kandidátus

Egyetemi tanár

Szegedi Tudományegyetem
Prof. Dr. Lengyel Imre, MTA doktora Intézetvezető egyetemi tanár Szegedi Tudományegyetem 



\section{Tartalomjegyzék}

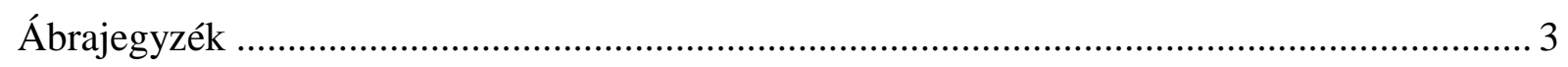

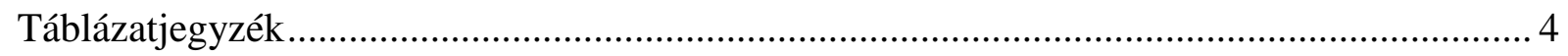

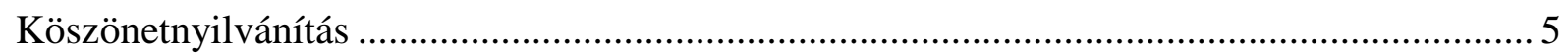

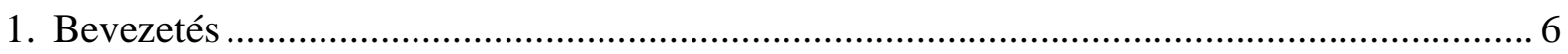

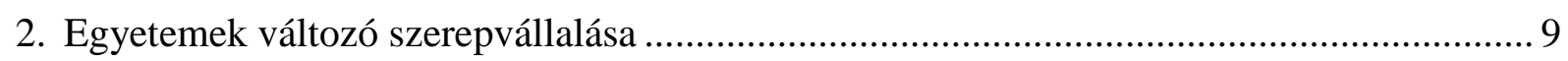

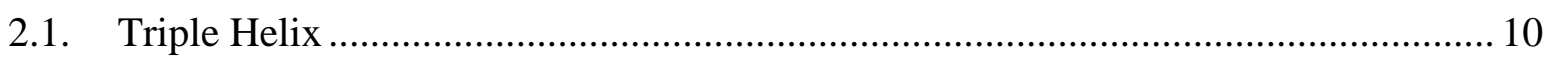

2.1.1. Egyetemek szerepe a regionális triple helixen belül ...................................... 13

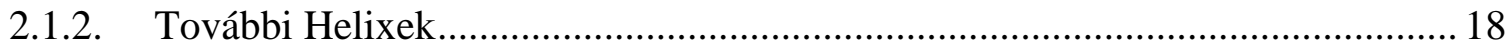

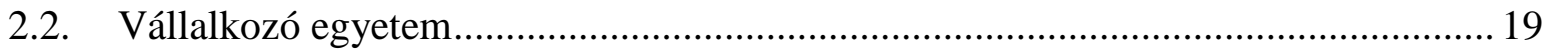

3. Vállalkozásoktatás, mint a vállalkozó egyetem egyik lehetséges alapfunkciója.................28

3.1. „Entrepreneurship” fogalmának megragadása...................................................... 28

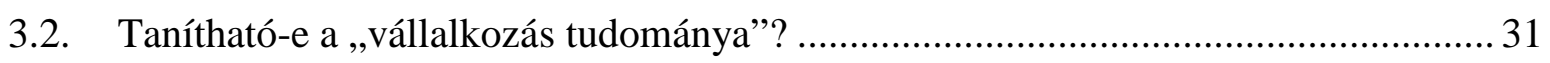

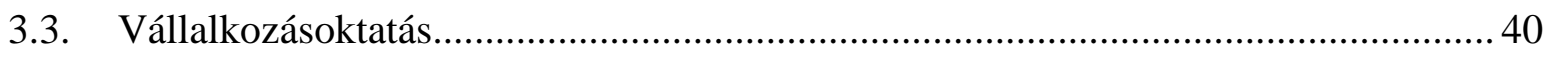

3.4. Vállalkozásoktatás céljainak és célcsoportjainak meghatározása.............................50

3.5. Vállalkozásoktatás és vállalati oktatás közötti eltérések........................................57

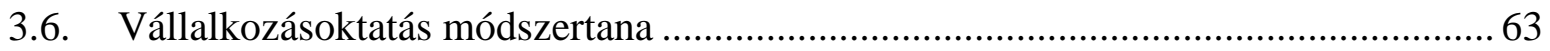

3.7. Nemzetközi kitekintés: vállalkozásoktatás az USA-ban és Európában ..................... 67

3.8. Hazai kitekintés: vállalkozásoktatás Magyarországon............................................ 70

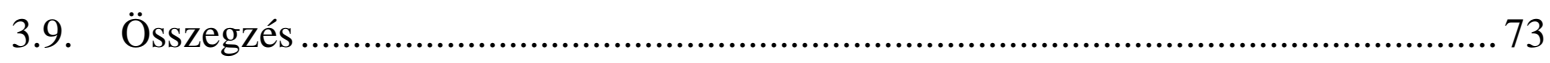

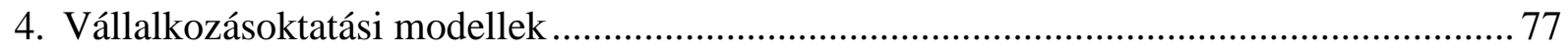

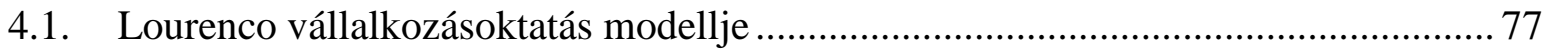

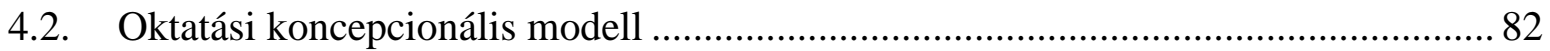

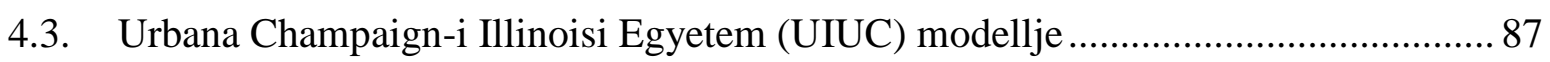

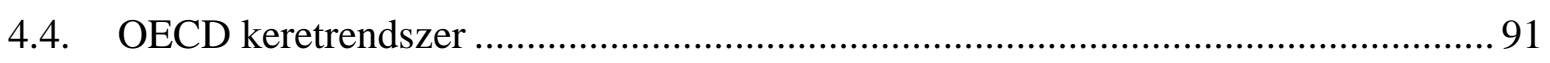

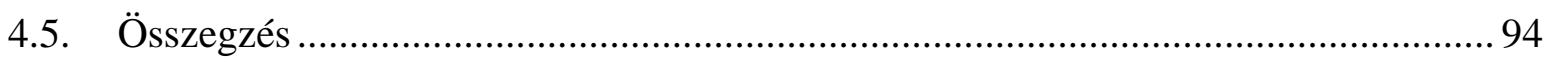

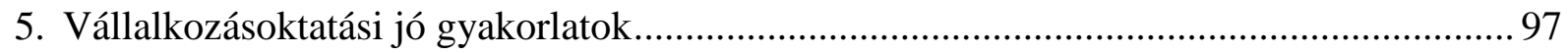

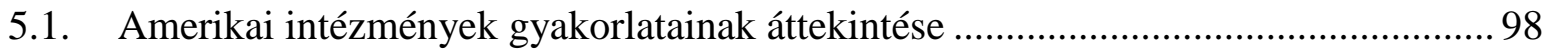

5.2. Európai egyetemek gyakorlatainak áttekintése ................................................... 108 
5.3. Összegzés

6. SZTE Vállalkozásfejlesztési-, vállalkozásoktatási modell kereteinek kialakításával kapcsolatos primer kutatások

6.1. A vállalkozásoktatás és az egyetem lehetséges szerepe a Dél-alföldi régió vállalkozásainak fejlődésében (Kérdőíves kutatás)

6.2. SZTE lehetséges szerepe a hallgatók vállalkozóvá válásának elösegítésében (Szakértői interjúk)

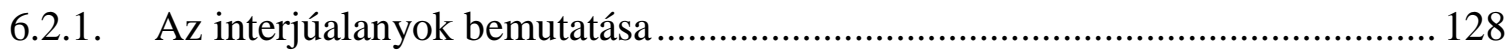

6.2.2. Szakértői interjúkból adódó megállapítások …………....................................... 129

6.3. Vállalkozó hallgatók a Szegedi Tudományegyetemen, egy kutatás tapasztalatai mélyinterjúk

6.4. A Szegedi Tudományegyetem vállalkozásoktatásával kapcsolatos megállapítások 147

6.5. SZTE vállalkozásfejlesztési-, vállalkozásoktatási modell kereteinek bemutatása... 148

6.5.1. Szervezeti javaslatok 151

6.5.2. Vállalkozói attitűd fokozásával kapcsolatos javaslatok 155

6.5.3. Konkrét vállalkozásfejlesztési-, különösen vállalkozásoktatási szolgáltatásokkal kapcsolatos javaslatok 156

7. Összegzés. 159

Irodalomjegyzék 162

Mellékletek. 172 


\section{Ábrajegyzék}

1. ábra: Kutatás menete …...................................................................................... 7

2. ábra: Az egyetem- ipar- kormányzat ,Triple Helix” modellje........................................... 11

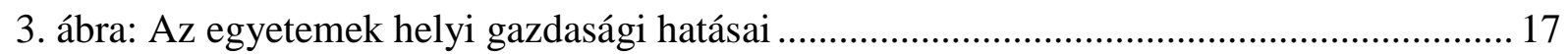

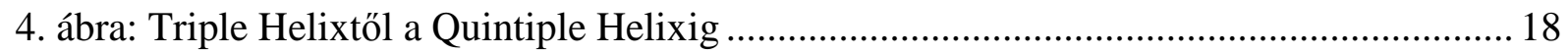

5. ábra: A vállalkozói egyetem kialakítására és fejlődésére ható tényezők ............................ 22

6. ábra: A Triple Helix modell alapja - felsőoktatás, kormány és magánszféra partnerség .... 23

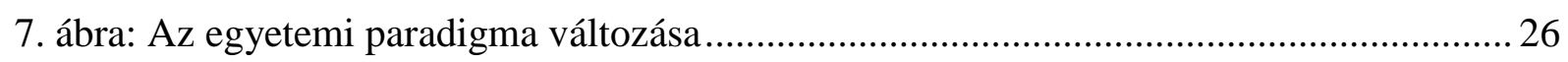

8. ábra: A vállalkozásoktatás fogalmi kerete a vállalkozás-orientált egyetemen..................... 34

9. ábra: Az „entrepreneurship”-hez kapcsolódó kereslet-kínálat tényezők ............................... 45

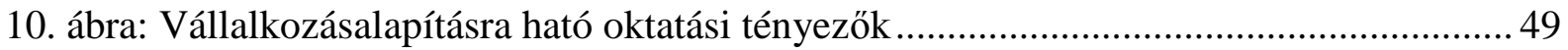

11. ábra: Vállalkozásoktatás - vállalkozói oktatás - vállalati oktatás .................................. 60

12. ábra: A vállalkozásoktatás, az inkubátorok és a kockázati tőke összefüggése a

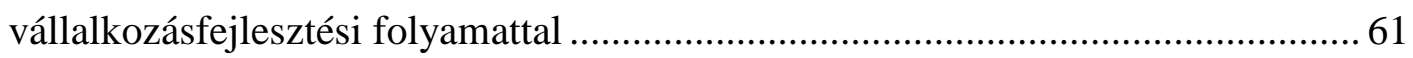

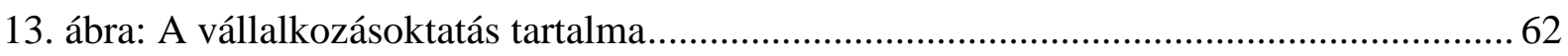

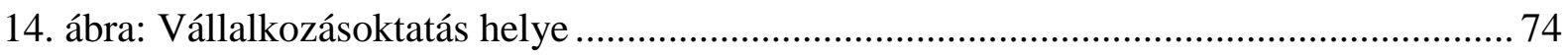

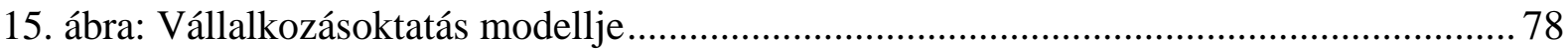

16. ábra: Oktatási koncepcionális modell vállalkozásoktatás részére .................................... 83

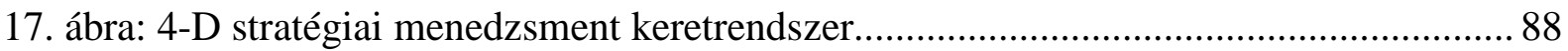

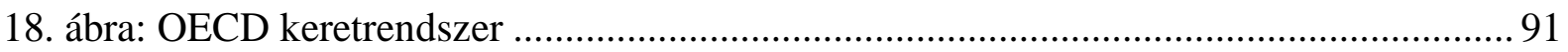

19. ábra: Vállalkozásfejlesztés - vállalkozásoktatás kritikus pontjai .................................... 149

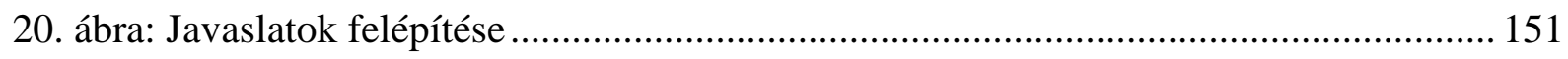




\section{Táblázatjegyzék}

1. táblázat: Vállalkozó egyetem definíciója ........................................................................ 20

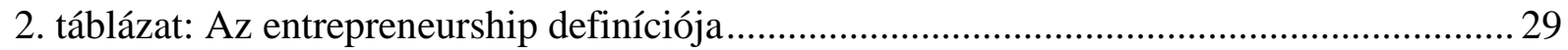

3. táblázat: Egyetemi kínálat vs vállalkozók tanulási igényei............................................ 32

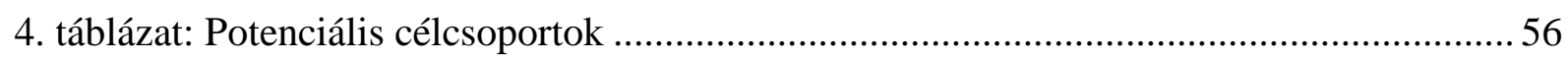

5. táblázat: A modern pedagógia fejlődésének egyszerűsített áttekintése.............................. 65

6. táblázat: A vállalkozásoktatási módszerek előnyei és hátrányai ........................................66

7. táblázat: A vállalkozásoktatás lehetőségei és kihívásai Közép-, Kelet-, és DélkeletEurópában - Javaslatok a felsőoktatási intézmények számára ...............................70

8. táblázat: Pedagógiai módszerek az egyes szintek esetében.............................................. 80

9. táblázat: Pedagógia, mintaterv és tervező ...................................................................... 81

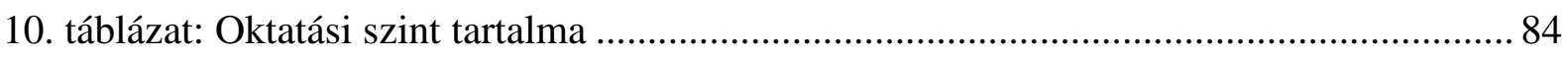

11. táblázat: A vállalkozásoktatás tanulási folyamatainak fó dimenziói és fogalmai .............. 86

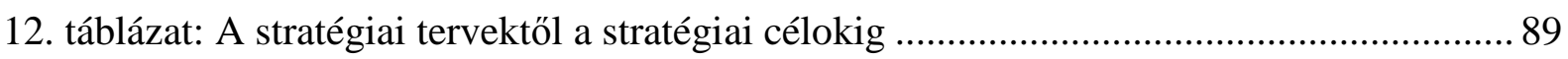

13. táblázat: Áttekintett modellek adott szempontok szerinti összefoglalása ......................... 94

14. táblázat: Az egyes modellekből leszürhető, további fontos tényezők összefoglalása........ 96

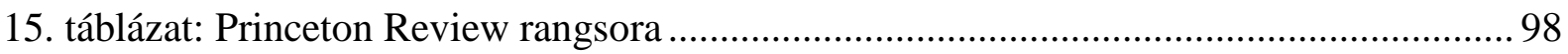

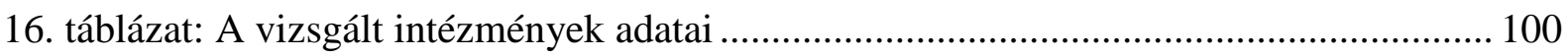

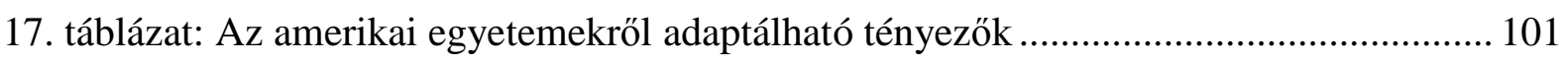

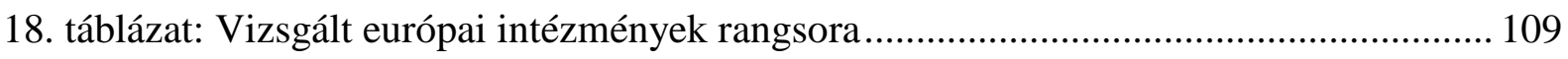

19. táblázat: Mennyire voltak fontosak az alábbi teendők a jelenlegi vállalkozás

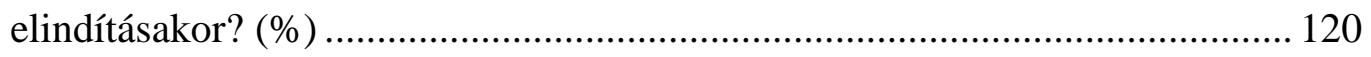

20. táblázat: Az egyetem szerepével kapcsolatos megállapításokra adott válaszok

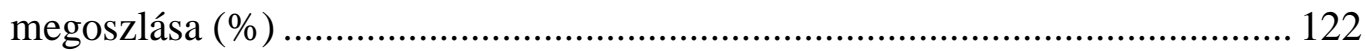

21. táblázat: Az egyes ismereteknek tulajdonított fontosság megoszlása (\%) ....................... 123

22. táblázat: Az egyes ismeretekre fektetett hangsúly megoszlása (\%) ................................ 123

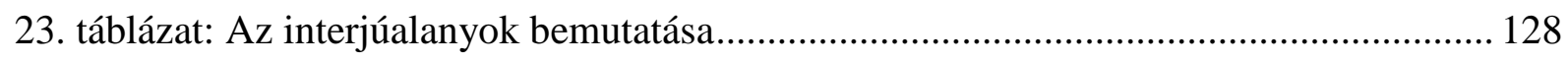

24. táblázat: Szakértői interjúk eredményeinek összefoglalása .......................................... 142

25. táblázat: Az interjúalanyok beazonosítása .................................................................... 144 


\section{Köszönetnyilvánítás}

Doktori kutatásaimhoz, valamint a disszertáció elkészítéséhez a legfontosabb hátteret Családom és különösen a Férjem támogatása (és főként türelme) jelentette, amiért nagyon hálás vagyok.

Kutatási tevékenységemet Prof. Dr. Lengyel Imre és Prof. Dr. Dinya László témavezetőim kiemelkedő jelentőségű segítségével végeztem, ezúton is szeretnék köszönetet mondani tanácsaikért és biztatásukért.

Külön köszönet illeti a munkahelyi vitára leadott kézirat opponenseit, Dr. Kállay Lászlót és Dr. Vilmányi Mártont. Mindkettőjük opponensi véleménye számos hasznos észrevételt, építő jellegű kritikát tartalmazott, amelyek elősegítették a disszertáció jelen formájának kialakulását.

Szeged, 2014. április 17.

Imreh-Tóth Mónika

doktorjelölt 


\section{Bevezetés}

A XXI. században a kreativitás, az innováció és a vállalkozás fogalmak váltak a modern gazdaságfejlesztés kulcsfaktoraivá. A kis-és középvállalkozások egyaránt fontos szerepet játszanak az Európai Unió versenyképességének növelésében, a gazdasági fejlődésben, valamint az önmegvalósításban.

Az utóbbi években a vállalkozóvá válás, annak ösztönzése, illetve a vállalkozásoktatás rendkívül nagy figyelmet kapott a fejlett országokban. Mindez számos okra vezethető vissza: a tudásintenzív kis-és középvállalkozások gazdaságfejlesztésben betöltött erősödő szerepe, (az egyre „divatosabb”) startupok és kapcsolódó „ökoszisztéma” kialakulása, vállalkozói létforma felértékelődése stb.

A vállalkozói létforma egyik megvalósulási formáját a különböző egyetemekröl, kutatóhelyekről kipörgő cégek jelentik. Jelen kutatás keretein belül a kutatóhelyekről kipörgő cégek fogalmát a lehető legbővebben értelmezem. Ebbe éppúgy beletartoznak a felsőoktatásban részt vevő hallgatók által alapított, ún. hallgatói vállalkozások, mint a klasszikus kutatók által létrehozott spin-off cégek.

A fentiek következtében egyre markánsabban felmerül az a kérdés, hogy a felsőoktatási intézmények - összhangban az egyre erősödő harmadik missziójukkal - milyen módon tudnának aktívabb szerepvállalást tanúsítani a vállalkozóvá válásban. A nemzetközi tendenciák világosan érzékeltetik a terület felértékelődését az elmúlt 20 évben, gyakorlatilag megszámlálhatatlan különféle megjelenési formája alakult ki az egyetemek vállalkozástámogatási szerepvállalásának.

Érdeklődésem az utóbbi években a kreativitás-innováció-vállalkozás lehetséges melegágya, az egyetem, annak vállalkozó-egyetemmé válása, illetve vállalkozásalapításban betöltött (betölthető) szerepe felé irányult. Annak ellenére, hogy az elmúlt évtizedekben az Amerikai Egyesült Államokban és Nyugat-Európában a vállalkozóvá válás ösztönzése folyamatosan fejlödik újabb és újabb programok, kurzusok keretein belül, addig a Szegedi Tudományegyetemen még nem figyelhető meg - néhány kezdeményezéstől eltekintve - egy markáns elmozdulás. Éppen ezért disszertációmat a Szegedi Tudományegyetemen megvalósítható vállalkozásfejlesztésnek, vállalkozásoktatásnak szentelem. 


\section{Kutatás célja}

A kutatás célja a Szegedi Tudományegyetem vállalkozásfejlesztési-vállalkozásoktatási modell keretrendszerének kidolgozása az amerikai és nyugat-európai jó gyakorlatokból adaptálható módszerek, primer kutatásokból származó eredmények felhasználásával (1. ábra).

\section{1. ábra: Kutatás menete}

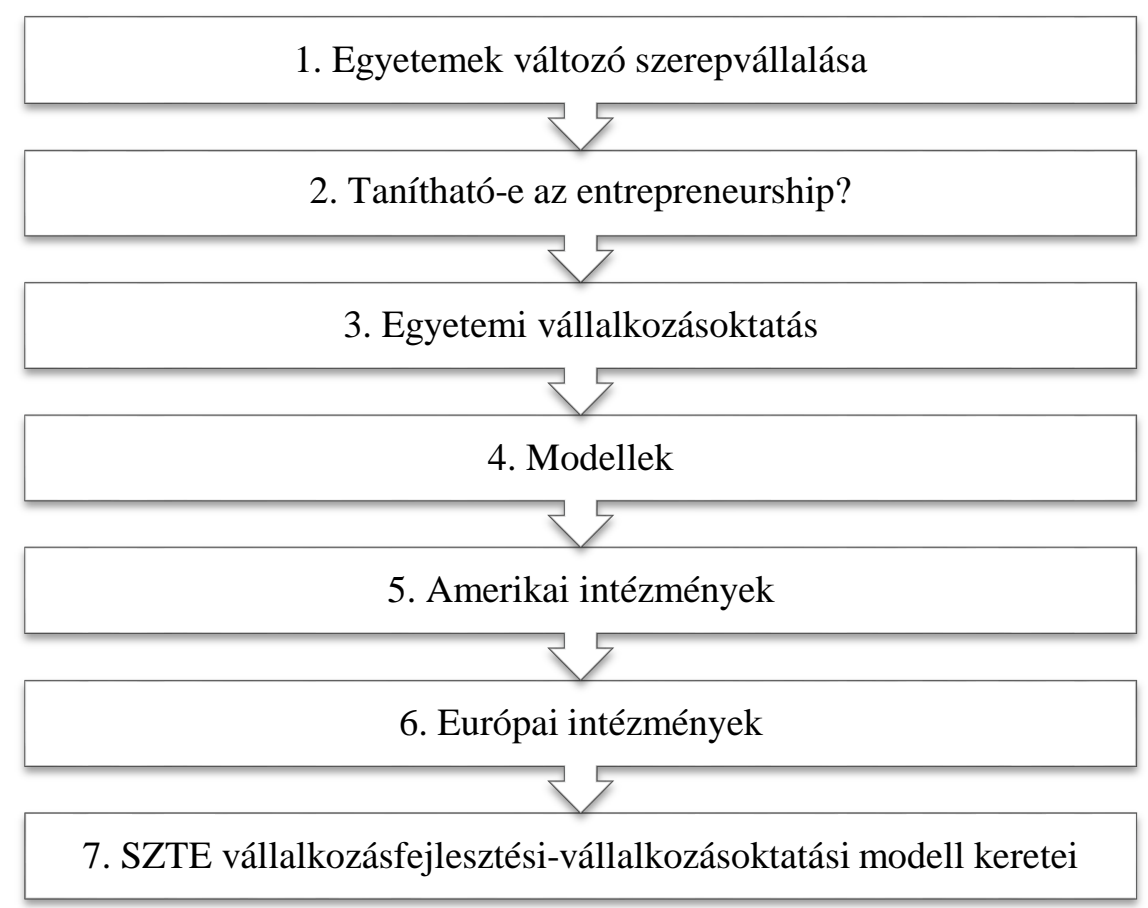

Forrás: Saját szerkesztés

A kutatási cél eléréséhez első lépésben áttekintem a releváns szakirodalmat, azon belül is három fő területet érintek. Egyrészt megnézem az egyetemek változó szerepvállalásának legfőbb jellegzetességeit, kitérve a triple helix modellre és továbbfejlesztési lehetőségeire. Másrészt a tanulható és tanítható-e az „entrepreneurship” - szakmát is megosztó - kérdését vizsgálom. Ezt követően a vállalkozásoktatás fogalmát, céljait tekintem át annak érdekében, hogy kijelöljek egyfajta határt, amelyen belül tovább vizsgálódok. Végül, a későbbi keretrendszer kidolgozása megalapozása céljából, vállalkozásoktatási modelleket mutatok be.

Szekunder kutatásaim során a „piacvezető”, vállalkozásoktatás területén vezető szereppel bíró amerikai intézmények közül a Princeton Review rangsora élén szereplő intézményeket, valamint az MBA50.com Premiership 2013 alapján kiválasztott vezető nyugat-európai intézményeket vizsgálom. Úgy gondolom, hogy a Szegedi Tudományegyetem vállalkozásfejlesztési-vállalkozásoktatási modell kereteinek kidolgozásához szükséges mind 
az elméleti modellek áttekintése, mind a gyakorlati példák elemzése. Éppen ezért kísérletet teszek az elméleti modellekből, valamint a jó gyakorlatokból adaptálható módszerek összegyüjtésére, valamint javaslatot teszek ezen módszerek szegedi adaptációjára.

Nyilvánvalóan, a társadalmi-gazdasági, illetve kulturális különbözőségek következtében nem „másolható” le a „legjobb gyakorlat”, többek között azért sem, mert nem létezik. Attól függően, hogy milyen környezetben, milyen szabályok szerint müködik egy adott intézmény, számtalan hatás befolyásolja saját módszerének kialakulását, fejlődését. Emellett a vállalkozói létforma sokfélesége a vállalkozásoktatás sokféleségében is megjelenik. Kétségtelenül léteznek közös (és szükséges) szempontok (pl. vállalkozásindítás, könyvelő választása), azonban ezeken túl minden vállalkozás más és más, hiszen maga a vállalkozó személye is minden esetben egyedi, ami magával hozza a vállalkozásoktatás sokszínüségének szükségességét is.

Végül, dolgozatom hatodik fejezetében bemutatom empirikus vizsgálataim, a kérdőíves kutatás és szakértői interjúk legfontosabb eredményeit. Továbbá, a szakirodalom és az empirikus kutatások eredményei alapján három szinten fogalmazok meg javaslatokat a Szegedi Tudományegyetem vállalkozásfejlesztési-vállalkozásoktatási modelljének kereteire.

A szakirodalmi és az empirikus kutatást az alábbi kérdések figyelembevételével folytattam:

1. Az egyetemek szerepvállalásának vizsgálata: hogyan változik az egyetem szerepe és válik vállalkozóvá?

2. Mennyire taníthatóak a vállalkozói készségek? Az oktatással mennyire segíthető elő a vállalkozóvá válás?

3. Az egyetemi vállalkozásoktatás milyen módszerekkel érhet el valós és hatékony eredményeket?

4. Az Amerikai Egyesült Államokban már nagy múlttal rendelkező intézményektől milyen, vállalkozásoktatással kapcsolatos módszerek, tapasztalatok adaptálhatók a Szegedi Tudományegyetem részére?

5. A kulturális-társadalmi szempontból nagyobb hasonlóságokat mutató európai intézményektől milyen közös módszerek/irányelvek vehetők át?

6. A szakértői interjúk alapján mely pontok lehetnek az SZTE vállalkozásfejlesztésivállalkozásoktatás modelljének alapkövei? 


\section{Egyetemek változó szerepvállalása}

Napjainkban a gazdaság müködését egyre inkább a tudásintenzív vállalkozások, és egyáltalán a tudáson alapuló kapcsolatrendszerek határozzák meg. A fejlettebb gazdaságok teljesítőképességét és versenyképességét alapvetően a tudáson alapuló hozzáadott érték determinálja.

Ennek megfelelően az egyetem, s maga a felsőoktatás is újabb kihívásoknak néz elébe, hiszen az egyetemek külső és belső környezete is átalakulóban van. Míg az első generációs egyetemek esetében az intézmények legfontosabb feladata az oktatás (tudás közvetítése) volt, addig a második generációs (Humboldt-típusú) egyetemeknél már megjelenik a kutatási tevékenység (tudás létrehozása). Jelenleg az egyetemek második nagy átalakulási folyamata zajlik, amelynek következtében a második generációs egyetemek harmadik generációs egyetemekké válnak, ahol az oktatás és kutatás mellett megjelenik a tudáshasznosítás is (Youtie-Shapira 2008, Wissema 2009). A harmadik generációs egyetemek irányába történő elmozdulást számos tényező befolyásolja (Wissema 2009):

- finanszírozási források keresése (magas színvonalú kutatási tevékenység érdekében),

- globalizáció (verseny a hallgatókért, oktatókért, kutatásokért),

- tudás hasznosítása (üzleti tevékenység, gazdasági növekedésben betöltött szerep),

- interdiszciplináris müködés (karok közötti együttmüködés),

- tömegképzés (illetve azon belüli „elitképzés”).

Ahhoz, hogy egy egyetem harmadik generációssá váljon (annak vállalkozói aspektusát tekintve), jelentős átalakuláson kell keresztülnennie: az egyetem vezetésének megfelelő ösztönzési rendszereket kell kidolgoznia (Friedman and Silberman 2003), az egyetemnek megfelelő infrastruktúrát kell biztosítania (Gjerding et al. 2006), decentralizált üzleti vezetési stílust kell bevezetni (Debackere - Veugelers 2005), valamint - ami talán a legfontosabb megfelelő vállalkozói kultúrát, szemléletmódot szükséges kialakítani az egyetem egészére vonatkozóan (Clark 1998, Jacob 2003, Guerrero - Cano 2006).

Az előzőekkel párhuzamosan az utóbbi években egyre inkább felértékelődtek a globális és regionális szerveződési szintek, ezzel egyidejűleg megfigyelhető a tudásalapú gazdaság elterjedése. Világossá vált, hogy azoknak a hálózatoknak, amelyek egyénekkel és szervezetekkel építettek ki kapcsolatot funkcionális területeken (kutatás, termelés, logisztika, vagy marketing) növekszik a befolyásuk azokhoz képest, melyek egy tradicionálisabb 
vertikális láncban kapcsolódnak partnereikhez (OECD 2003). Egy ehhez szorosan kapcsolódó másik tendencia a szereplők széles spektrumát felvonultató (szállítók, fogyasztók, tudományos szervezetek, üzlet-orientált szolgáltatók, közintézmények) hálózatok gyors fejlődése. Az innovatív hálózatok nem csak profitorientált vállalkozások között alakulnak ki, hanem a partnerek számos különböző területről szerveződnek. A kis- és középvállalkozások, illetve a nagyvállalkozások és a kutatóintézetek közötti kooperációk egyre fontosabbá válnak, mivel ezek a munkamegosztás hatékony módját jelentik az innovációs rendszeren belül mindenki előnyére. Értelemszerűen ebben az esetben is a specializációban rejlő előnyök minél magasabb fokon történő kihasználása az együttmüködés fő motivációja, amely egy jelentős tudásáramlással párosulhat (OECD 2003).

Napjainkban az ilyen sokszínű és rendkívül összetett kooperációk egyik legérdekesebb gyakorlati megvalósulása az ún. triple helix, illetve az ezen belül megjelenő vállalkozó egyetem koncepció. A témakör könyvtári szakirodalmán belül jelen fejezetben az egyik legismertebb elméleti modellt, a triple helixet mutatom be, különös tekintettel a lokális gazdaságfejlesztési aspektusaira, amely véleményem szerint a vállalkozó egyetem kutatásának megfelelő alapot nyújt.

\subsection{Triple Helix}

A triple helix fogalom egy, a biotechnológiától kölcsönzött metafora. A triple helix három spirálból áll, és a biofizikában ismert biomolekuláris DNS szerkezetre utal. A hasonlatot a társadalomban működő három erő vagy szereplő szemléltetésére használják, nevezetesen a tudomány (egyetem), a vállalkozások (gazdasági szféra), valamint a kormányzat (2. ábra). Kormányzat alatt itt a másik két szereplő számára szabályokat és normákat előíró erőt kell érteni (Braun-Diensberg 2007). Az említett három szféra közötti folyamatos kommunikáció hozzájárul mindhárom egység fejlődéséhez, illetve tudásteremtő régiók létrejöttéhez (Lengyel 2005).

Fontos kiemelni, hogy az ilyen jellegű kooperációk soha nem egy statikus kiforrott konfigurációt alkotnak, sokkal inkább dinamikus, hálózatokra jellemző tulajdonságokat mutatnak. Az állami-magán, a tudomány-technológia, az egyetem-ipar közötti határvonalak állandó változásban vannak. Egy triple helix konfigurációban a kutatás, a technológia és a fejlesztési hálózatok egyre inkább módosítják a $\mathrm{K}+\mathrm{F}$ célú releváns környezeteket (Leydesdorff 2000). 


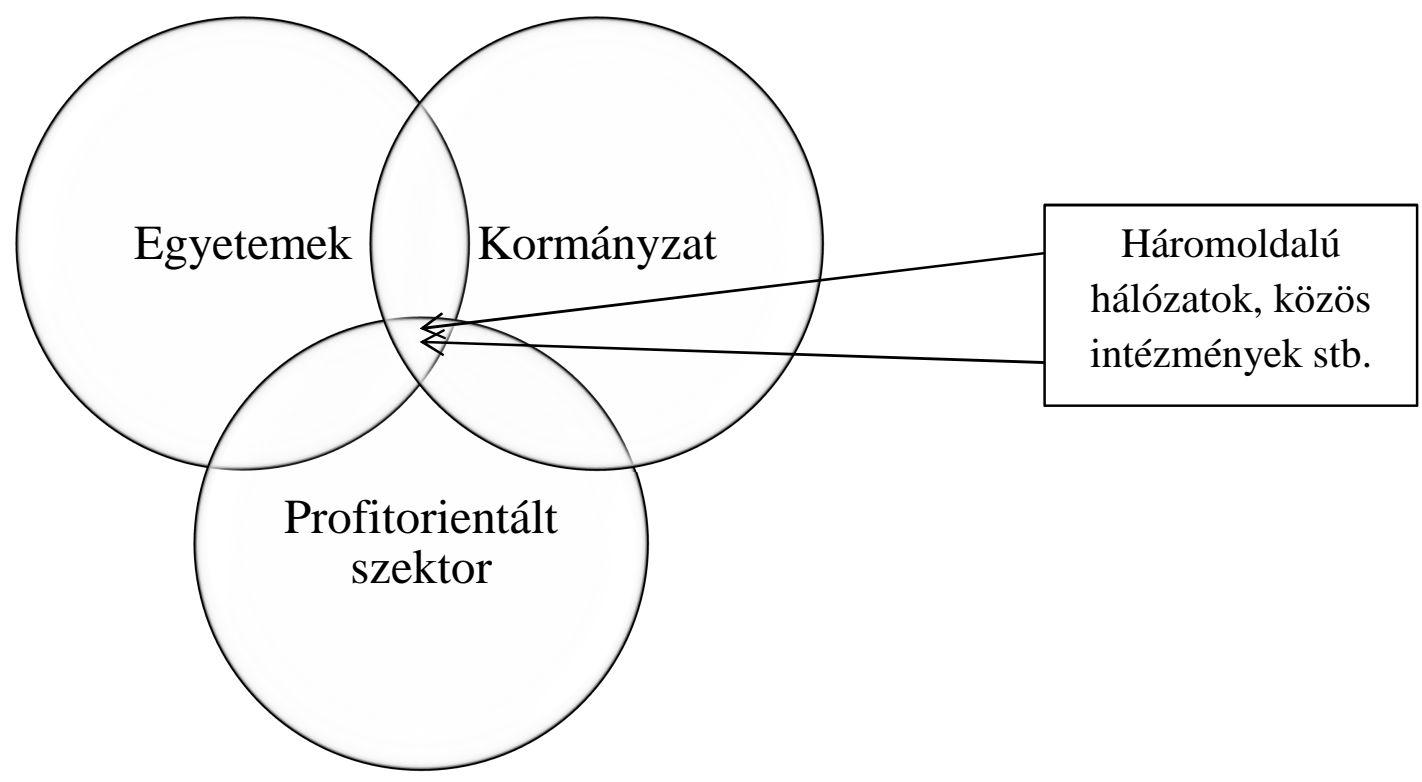

Forrás: Etzkowitz-Leydesdorff (2000, 111. o.), alapján Lengyel (2005)

A biológiai evolúcióval ellentétben a "gének" nem adottak, hanem a modern társadalmak szociális, technológiai és gazdasági evolúciója során alakulnak ki, saját maguk és interakcióik működési átalakításával, konfigurációjuk átszervezésének segítségével. Egy új rezsim alatt a rendszer újra felépül a korábbi állapotok halmazából, beleértve a természetes környezetet és a társadalom közösségi gyökereit. Így a technológia társadalmi eredményként ünnepli a közösséget, beleértve a „természet” és „kultúra” folyamatos újradefiniálását (LeydesdorffEtzkowitz 1998).

Fontos észrevenni, hogy az egyetemi-kutatói szféra relatív felértékelődése történik meg napjainkban, mivel triple helix-ek alakulnak ki azáltal, hogy az egyetem egyenlő státuszba emelkedik a gazdasággal és a politikával. Ilyen értelemben az egyetemek, kutatóintézetek egyre inkább egyenrangú partnerei lehetnek a másik két szereplőnek (Etzkowitz - Zhou 2007).

A triple helix különböző kiindulópontokkal rendelkezhet: különálló intézményi szférákból, amelyek egymástól elszeparáltan müködnek, illetve valamelyik tartalmazza és irányítja a többit. A globális trend egy olyan módozat felé mutat, amelyben a különböző szférák autonómok, viszont átfedésben vannak, nem teljesen eltérőek, de nem is teljesen egyesültek (Etzkowitz et al. 2007). Ahogy az átalakulás megtörténik, a bilaterális interakciókról 
trilaterálisra váltanak, az egyszerü és dupla helixekről az egyetem-ipar-kormányzat közös projektjeire (pl. az USA-ban és Svédországban, ahol a PhD jelöltek vállalatoknál készítik el a disszertációjukat és a vállalati kutatók az egyetemeken szerzik meg felsőfokú okleveleiket). Az innovációs rendszerek tipológiája különböző nemzeti perspektívákat is tartalmaz, számos tényező mentén végül három - meglehetősen eltérő jellemzőket felmutató - hélix különíthető el. Az első típus a triple helix I egy államközpontú triple helix, melyben az állam valamilyen mértékben determinálja a tudományt és az ipart, továbbá irányítja a köztük lévő kapcsolatrendszer kialakulását és müködését. A második típus a triple helix II, egy ún. „laissez-faire triple helix”, egyértelmüen különálló intézményi szférákból áll, ahol a kormányzat, az egyetem és az ipar egymástól külön müködik. Mindenki önállóan hozza döntéseit. Ebben a modellben az egyetem biztosítja az alapkutatást és a képzett embereket. Általános jelenség, hogy a vállalatok egy iparágban egymástól teljesen külön müködnek és a piaci folyamatoknak megfelelően egymással versenyben állnak. A kormányzati szerepvállalás is korlátozott, legfontosabb feladata, hogy olyan megoldásokat nyújtson, amelyeket a magánszféra nem tud, vagy nem akar támogatni. A triple helix III, egy interaktív modell, átfedésben álló, mégis viszonylag független, intézményi szférákból áll (Etzkowitz et al. 2007).

Etzkowitz és Zhou (2007) a triple helix „müködési rendszerét” vizsgálják és jellemzik a vállalkozó egyetem szerepét a társadalmakban, melyek aszerint különböznek, hogy melyik helix a vezető innovációs szereplő. A rendkívül gyakran említett MIT és Stanford példák az amerikai egyetem által vezetett triple helix (university-pushed) modellre jó iskolapéldák. Kínára jellemző a kormányzat által vezetett (governement-pulled) triple helix modell, míg más országokban főként az ipar által vezetett triple helix modell a mindennapos gyakorlat. A tudás-túlcsordulás egyre inkább kialakul a kutatási eredmények egyetem területén történő kommercializációján keresztül, függetlenül a társadalmi vagy tudományos különbségektől. A vállalkozó egyetem az egyetem-ipar-kormányzat interakciók teremtő elve és az innováció forrása (Etzkowitz - Zhou 2007). Ilyen szempontból talán pontosan az egyetem megfelelő müködésén és helyes szerepfelfogásán múlik leginkább az egész müködési mechanizmus sikere, illetve sikertelensége.

Az egyetemekről származó tudás-túlcsordulás elősegíti a regionális fejlődést a kutatás kommercializációján, valamint az új vállalatok, humánerőforrások és új ötletek biztosításán 
keresztül. Elegendő itt a kialakuló kapcsolatokra, vagy akár az egyetemről egyre növekvő számban kirajzó spin-off ${ }^{1}$ tudásintenzív vállalkozások növekvő számára gondolnunk.

A triple helix alapján magát az egyetemet, valamint a társadalomban betöltött szerepét felértékeli az a tény, hogy részt vesz a tudás hasznosításában (amennyiben a harmadik generációs egyetemeket nézzük), és ennek egyik pozitív következménye az új kutatási kérdések felvetődése. A számos pozitívum mellett azonban nem szabad figyelmen kívül hagyni a bekövetkező folyamatok esetleges ,negatív mellékhatásait” sem. Az elmélet legfőbb kritikusai szerint vélelmezhetően pontosan az egyetem sérül ebben a folyamatban, mivel egyértelműen kockáztatja eredeti (speciális) küldetését, mivel túlzottan piacorientált müködési modellt kell megvalósítania (Etzkowitz - Zhou 2006).

Összességében megkockáztatható, hogy bár egyértelmủek a lehetséges szinergikus hatások, ezek ára túlságosan magas. Gondoljunk bele az egyes szereplőkkel szembeni vélt és valós elvárásokba, illetve abba, hogy ez gyakran milyen komoly szakítást jelent az eddig folytatott gyakorlatukhoz képest. Az ideális vállalkozó egyetemekkel szemben elvárás, hogy vezető szerepet játszanak a regionális innovációban és ösztönözzék a start-up vállalkozásokat. Ehhez hasonlóan az iparral szemben elvárás a hálózatosodás, illetve egyáltalán a kooperatív magatartási minták megvalósítása. A kormányzati szerepvállalás is más értelmet nyer, hiszen a döntéshozóktól elvárt, hogy más szereplőkkel együttműködve fejlesztési programokat hozzon létre, hogy támogassa az egyetem, az ipar és a köztük lévő kapcsolat fejlődését. A három szférával szemben elvárás, hogy cselekedjenek és egymással együttműködve megvalósítsanak egy gazdasági növekedési stratégiát.

\subsubsection{Egyetemek szerepe a regionális triple helixen belül}

Az egyetem fokozott szerepe a tudás-alapú gazdaságfejlesztésben jól megfigyelhető regionális szinten, ahol számos módon aktív: biztosítja a „tudásteret”, a technológiaalapú vállalatok inkubációjának erőforrásait; a „konszenzus teret”, vezető szerepet a kormányzattal és iparral történő együttműködés kialakításában; valamint az „innovációs teret”, új szervezeti formák kialakítását (Etzkowitz 2004). Egy megközelítés szerint a régiók versenyképessége értelmezhető úgy is, mint az ott működő vállalatok versenyképességének egyfajta összegződése (Lengyel 2003). Éppen ezért az egyetem vállalkozóvá válása, valamint

\footnotetext{
${ }^{1}$ A spin-off vállalkozásokat rendszerint professzorok, fiatal kutatók, esetleg PhD hallgatók indítják el, valamint egyetemi környezetben, vagy magán, illetve állami tulajdonú kutatási laboratóriumokban hoznak létre (ChiesaPiccaluga 2000).
} 
vállalkozásoktatási szolgáltatás nyújtása révén közvetve nagymértékben hozzájárulhat a regionális versenyképesség növeléséhez. Továbbá, regionális szinten különösen felértékelődnek az egyetemek köré szerveződő kooperációs hálózatok. Ahogy Gál (2005) fogalmaz: „A régiók vonzereje és versenyképessége nagymértékben függ az innovációba bekapcsolódó egyetemek és vállalatok térben kiegyensúlyozott hálózati együttmüködésétöl. A helyi tudásbázisok, az innovációs potenciál kihasználása és az egyetem-gazdaság együttmüködés jelentősen hozzájárul nemcsak a vállalatok, de a régió teljesítményének a javításához" (Gál 2005, 269. o.).

A triple helixen belüli három szektor szerepe folyamatosan változik a tudásalapú gazdaságban, sőt fontos a három szektor egymásba történő átmenete, a tevékenységek közötti átfedés és a szervezeti korlátok eltörlése (Lengyel 2005). A modell egyik legfontosabb megállapítása továbbá a szektorok közötti folyamatos kommunikáció, amely egyaránt biztosítja mindhárom szektor fejlődését. A modell megállapításaival kapcsolatban két visszautalást tennék az eddigiekhez. Egyrészt a szervezeti korlátok lebontása szorosan kapcsolódik a szervezetekben dolgozó emberek értékrendje közötti különbségek mérsékléséhez, azaz a modell kereteiben gondolkozva ezen a területen is meg kell kísérelni valamilyen beavatkozást. Másrészt a folyamatos kommunikáció pontosan az előzőekben tárgyalt „,interakciókon keresztüli tanulás” alaptényezője. Ezért a „vállalat-vállalat” közötti interakciók kiterjeszthetők szektor-szektor közötti interakciókká, amelyek szintén a gördülékenyen müködő széles hálózatok irányába hathatnak.

A fentiek alapján úgy gondolom, hogy a potenciális szereplők tudatos kapcsolatépítése az egyik legfontosabb sikerfaktor, azaz ezen a területen is szükség van az együttmüködésekre való hajlandóságra és az „alulról (is) jövő” kezdeményezésekre. Ki kell emelni, hogy a partnerek mindegyike felismerte a közös érdekeket, és egy rendkívül dinamikusan fejlődő kapcsolati háló alakult ki a különböző stakeholderek között. Gyakorlatilag három érdemi szereplö-csoport különíthető el az együttmüködés keretein belül.

Egyrészt az egyetemek világosan felismerték, hogy az egyetemeken fellelhető szellemi kapacitás rendkívül jól hasznosítható az együttműködések keretein belül. A kooperáció következtében egyre nagyobb jelentőséget kapnak a részben vagy egészben a profitorientált szféra által finanszírozott kutatások. Másrészt a profitorientált szféra egyértelműen elsődleges hasznosítójává vált az eredményeknek. A kutatási igényeit helyben kielégíti az egyetemi 
szféra, és a finanszírozási kondíciók is kedvezőek, az esetek nagy hányadában közösen finanszírozzák a projekteket a különféle kutatási egységekkel, és közösségi támogatásokat is kapnak (hazánkban ez különösen fontos pl. az uniós források tekintetében). Végül, a települési és regionális döntéshozók (közösségi szektor) egyrészt segítséget nyújthatnak az egyes projektek finanszírozásában, másrészt - és ezt a tényezőt legalább olyan fontosnak tarom, mint az előzőt - bevonhatják az egyetemeket, kutatóintézeteket a döntéshozatalba, különösen a gazdaságfejlesztési döntések esetén.

A vállalkozói aktivitás és innováció érdekében létrehozott regionális rendszerek kiépítéséhez az egyetem - vállalkozás - kormányzat triple helix interakciójának új formáit kell megismerni. A modell az egyetem, a vállalkozás és a kormányzat közötti interakciót célozza meg, továbbá felismeri, hogy az egyetemek és a tudomány fontos szerepet játszik (és kell játszania) a regionális innovációs folyamatokban (Braun-Diensberg 2007). A modell továbbá kiemeli az együttmüködés kollaboratív és hibrid módozatainak szükségességét, valamint elismeri, hogy az irányítás nem stabil és előre összehangolt, hanem dinamikus jellegű.

A triple helix modellel kapcsolatban elmondható, hogy a vállalkozói egyetem egyesíti az oktatást, a kutatást és gazdasághoz való hozzájárulást, különösképpen helyi szinten (Martin Etzkowitz 2000). Amikor az egyetem vállalkozóvá válik, azonnal megváltozik a státusza is az innovációs folyamatban. Míg a korábbi „tudományos-kínálati” innovációs modell hasznos eszköznek bizonyult a kormányzati pénzek kutatásba történő befektetéséhez, addig most az a kérdés vetődik fel, hogy az ipari érdekekben történő tudományos kutatás gyengíti-e az egyetem autonómiáját, vagy, éppen ellenkezőleg, erősíti azt? Finanszírozási oldalról bizonyosan igaz ez a függetlenedési tendencia, mivel az egyetem autonómiáját valójában erősíti az, hogy csökken az állami finanszírozástól való függősége (Martin-Etzkowitz 2000).

Azzal, hogy az egyetem ,vállalkozó-egyetem” lesz, kialakítja kapcsolatait a régióval, az iparral és az állami kormányzattal is. A következő indikátorok hasznosak az egyetem és az ipar közötti együttmüködés eredményeinek értékelésében (Martin-Etzkowitz 2000):

- az egyetemtől származó új technológiai ötleteken alapuló spin-off vállalkozások,

- az új technológiák licencének értékesítése,

- tudás-túlcsordulási hatások.

A másik oldalról megközelítve, az egyetem együttmüködését a kormányzattal az egyetemi finanszírozás szerkezetének, az egyetem $\mathrm{K}+\mathrm{F}$ folyamatainak nyújtott kormányzati 
támogatásnak és az egyetem nagyobb kutatási projektekben történő részvételének segítségével lehet vizsgálni.

A nemzeti innovációs rendszerben (NIS) az egyetem szerepe növekszik, mivel vállalkozó jellegűvé vált. Ez egyben az egyetemi kollegialitás, autonómia és a tudományos eredmények vállalkozói értelmü átformálását is jelenti (Clark 2001).

A vállalkozói aktivitás kialakítása a triple helixen belül már létező regionális problémák felismerésével és megoldásával kell, hogy kezdődjön (Andrijevskaja - Met 2007). A triple helix versenyképessége abban rejlik, hogy az egyetem-ipar-kormányzat közötti együttműködés elősegítésén keresztül gazdasági növekedést generál.

Az egyetem, az ipar és a kormányzat, a triple helix, funkcióinak átalakulása megtörténik, ahogy az intézmények egyre jobban átveszik a másik szerepét. A triple helix nem csupán spirálok közötti interakció, hanem a szektorok fúziója: egyre több egyetem müködtet tudományos parkokat és üzleti inkubátorokat. A vállalatok kutatási tevékenységeket folytatnak, viszont az alapkutatásokat kormányzati intézmények finanszírozzák. A kormányzati és non-profit szervezetek együttmüködhetnek üzleti vagy oktatási tevékenységekben (Kim et al. 2012).

Az utóbbi években elmondható, hogy az egyetemek jelentős átalakuláson mennek át, egyre meghatározóbb szerepet játsszanak a tudásalapú táradalomban, elősegítve a regionális fejlesztést. Megfelelő vállalkozói szemléletmód kialakításával és stratégiai jövővel rendelkezve a vállalkozó egyetem együttműködik a többi szereplővel a regionális innováció elősegítésének érdekében. Lényegét tekintve, az oktatók új fényben látják a kutatást és az oktatást, amivel már hozzájárulnak a technológia transzferhez, a vállalatalapításhoz, csakúgy mint a hallgatók oktatásához és a tudás előmozdításához (Etzkowitz-Zhou 2007).

Amennyiben az egyetemek helyi gazdaságfejlesztési hatásait vizsgáljuk, akkor elmondható, hogy azok két csoportra oszthatók: kínálati (input), valamint keresleti (output) oldalon megjelenő hatások (Armstrong-Taylor 2000, Lengyel 2006, Lengyel 2012) (3. ábra). 


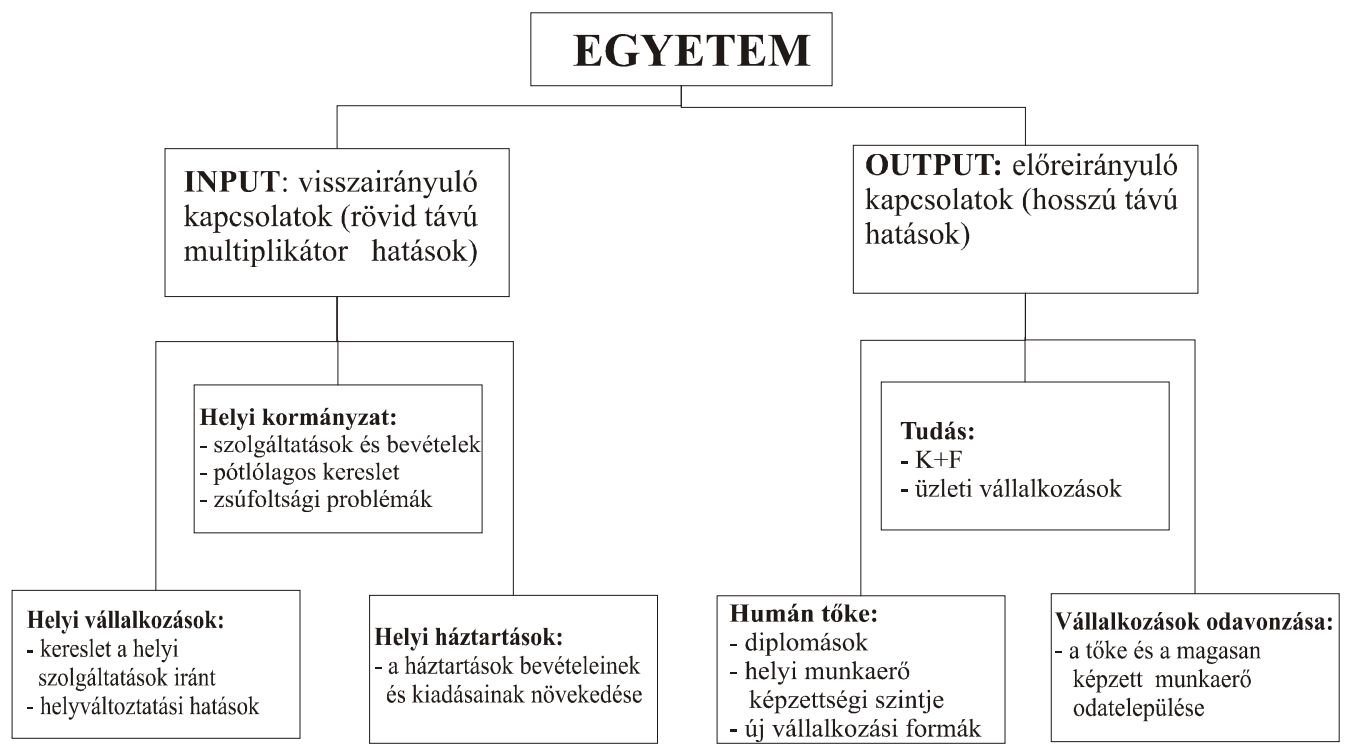

Forrás: Lengyel (2006), Lengyel (2012)

Az input oldalon megjelenő hatások például az egyetemi kiadások (épületek fenntartása, üzemeltetése), egyetemi hallgatók, oktatók, kutatók költései. Ezek a hatások függetlenek az egyetem specifikumaitól (képzések típusa, minősége, $\mathrm{K}+\mathrm{F}$ tevékenység mértéke stb.), minden egyetemi városban megfigyelhetök. Ezzel szemben az output oldali hatások, mint például kvalifikált munkaerő, egyetemi oktatók, kutatók $\mathrm{K}+\mathrm{F}$ tevékenysége és azok gazdasági hasznosítása már nem jelenik meg automatikusan, hanem tudatos egyetemi stratégia és helyi gazdaságfejlesztés eredményei (Lengyel 2012). És itt megint nagy szerepe lehet az egyetem erőteljes vállalkozásfejlesztési-vállalkozásoktatási szerepvállalásának mind az egyetemről kipörgő spin-off vállalkozások, mind a hallgatói vállalkozások támogatásában, mind az egyetem-vállalkozások együttmüködésnek kialakításában, mind pedig a $\mathrm{K}+\mathrm{F}$ tevékenységek eredményeinek piacosításában. Mindezt alátámasztja Buzás (2004) kutatása, amely azt mutatta, hogy a menedzseri készségek jelentik az egyik legnagyobb akadályt a spin-off vállalkozások létrehozásában, hiszen a kutatók nem rendelkeznek megfelelő ismeretekkel az üzleti működéssel, a vállalkozásindítással és működtetésével kapcsolatosan.

A fentiekben összefoglaltam a triple helix modell legfontosabb tulajdonságait, illetve az egyetemek gazdaságfejlesztésben betöltött lehetséges szerepét. A továbbiakban a triple helix modellhez szorosan kapcsolódó vállalkozó egyetem fogalomrendszerét vizsgálom. 


\subsubsection{További Helixek}

Elméleti és gyakorlati érdekességként feltétlenül meg kell említeni, hogy megjelennek kezdeményezések a triple helix modell további bővítésére fejlesztésére. A modellel kapcsolatban felmerült egy esetleges negyedik helix létezése (Etzkowitz-Zhou 2006). Ezzel kapcsolatosan olyan különböző tényezőkre tettek javaslatot, mint például a munka, a kockázati tőke, az informális szektor és a civil társadalom. A bővítésnek az a legnagyobb kockázata, hogy a negyedik helix bevezetésének eredményeképpen a triadikus modell elveszítheti kreatív dinamikáját. Mindenesetre - a lehetséges kockázatok ellenére is Etzkowitz és Zhou (2006) szerint ki kell bővíteni a modellt, amihez a szerzők az egyetemközszféra(public)-kormányzat „Fenntarthatósági Triple Helix” modellt javasolják, ezáltal bevezetve egy hiányzó elemet, és megőrizve a „tertius gaudens” dinamikus tulajdonságait.

A triple helix modell továbbgondolásával Carayannis és Campbell (2012) megalkották a Quadruple Helix modellt, ahol negyedik helix-ként a média és kultúraalapú közösségi tér és a civil társadalom közege jelenik meg.

4. ábra: Triple Helixtől a Quintiple Helixig

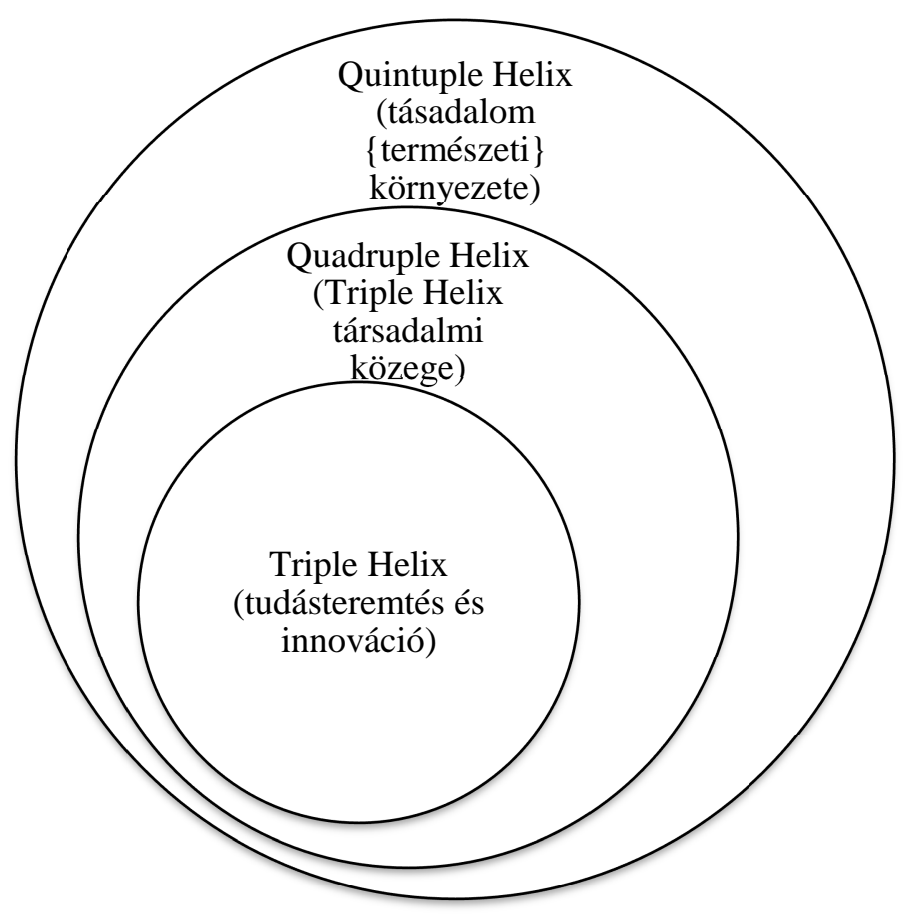

Forrás: Carayannis-Campbell (2012), 18. o. alapján saját szerkesztés

Ezen túlmenően - Etzkowitz és Zhou (2006)-hoz hasonlóan - itt is megjelenik a fenntartható fejlődés hatásainak vizsgálata a triple helix kibővítésére irányuló elképzelésekben. Ennek 
megfelelően Carayannis és szerzőtársai (2012) bevezették az ötödik helixet, amellyel megalkotta a Quintiple Helix modelljét és a globális felmelegedéssel járó kihívásokat helyezte elemzésének középpontjába, így az innovációs elemzésekben is megjelenik a fenntartható fejlődés és a társadalom müködésének ökológiára gyakorolt hatása (Vas 2012).

A fejlett és fejlődő országok egyaránt kísérleteznek a funkciók és intézmények előnyösebb összetételével az egyetem-ipar-kormányzat kapcsolatok triple helix modelljében. Például a tudomány és az egyetem a vállalatalapítás és a regionális fejlesztés forrása az alapvető tudás biztosítójának hagyományos szerepe mellett. A kormányzat segít az új fejlesztések támogatásában a szabályozási környezet módosításában, adórendszeren keresztüli ösztönzésen és állami kockázati tőke biztosításán keresztül. Az ipar veszi át az egyetem szerepét a képzés és kutatás fejlesztésében, gyakran ugyanolyan magas szinteken, mint az egyetemek. A legtöbb ország és régió jelenleg a triple helix III valamely formáját igyekszik megvalósítani, egyetemi spin-off vállalatokkal, trilaterális kezdeményezésekkel a tudásalapú gazdaságfejlesztés céljából és a vállalatok közötti stratégiai szövetségekkel (nagy- és kisvállalatok között, melyek különböző területen működnek és különböző technológiai szinten), kormányzat laboratóriumokkal és tudományos kutatócsoportokkal.

\subsection{Vállalkozó egyetem}

A következőkben a triple helix-hez kapcsolódva, a vállalkozó egyetem fogalomrendszerét vizsgáljuk. A vállalkozó egyetem a triple helix III. egy megvalósulási formáját jelentheti.

Ideális esetben a felsőoktatási intézmény-KKV együttmüködés kétirányú kapcsolat, melynek lényege, hogy míg a felsőoktatási intézményeket a kisvállalkozási közösséggel történő együttműködésre ösztönzik, addig a KKV-kat vonzza a „kereslet-alapú szerep”, valamint a kutatási és oktatási lehetőségekben való együttmüködés (Gordon 2012). Alapjában véve az alapfeltételezés az, hogy mindkét félnek együtt kell működnie és párbeszédet kell teremtenie a versenyképesség érdekében. Ennek elsősorban három oka van. Először is, a tudásalapú gazdaság fontosságának növekedése azt jelenti, hogy az egyetemek és üzleti szféra közötti kapcsolatok létrehozásával tudáscsere történik és így a nemzetek versenyképesebbekké válnak. Az új ismeretek elsajátításán és alkalmazásán keresztül történő tanulás képessége fontos tényező a szervezeti teljesítmény javításában, különösen a KKV-szektorban. A második ok annak felismerése, hogy az oktatás finanszírozási helyzete egyre nehezebb, így alternatív forrásokat kell találni, amennyiben az egyetemek fenn akarnak maradni. 
1. táblázat: Vállalkozó egyetem definíciója

\begin{tabular}{|c|c|c|}
\hline $\mathbf{E} \mathbf{v}$ & Szerző(k) & Definíció \\
\hline 1983 & Etzkowitz & $\begin{array}{l}\text { Egyetemek, amelyek új bevételi forrásokban gondolkodnak, mint például } \\
\text { szabadalmak, szerződéses kutatások és magánvállalkozásokkal folytatott } \\
\text { közös projektek. }\end{array}$ \\
\hline 1995 & $\begin{array}{l}\text { Chrisman, } \\
\text { Hynes és } \\
\text { Fraser }\end{array}$ & $\begin{array}{l}\text { A vállalkozói egyetem magában foglalja az egyetemi professzorok, kutatók, } \\
\text { illetve hallgatók általi új vállalkozások létrehozását }\end{array}$ \\
\hline 1995 & Dill & $\begin{array}{l}\text { Az egyetemi technológiai transzfer formális törekvések az egyetemi kutatás } \\
\text { hasznosítására a kutatási eredmények kereskedelmi vállalkozássá történő } \\
\text { fejlesztése által. A formális törekvések pedig a technológiai transzfer } \\
\text { elősegítéséért felelös szervezeti egységek }\end{array}$ \\
\hline 1998 & Clark & $\begin{array}{l}\text { Célja az üzleti alapokra helyezés innovációja Ebben az esetben az egyetem } \\
\text { arra törekszik, hogy jelentősen megváltoztassa, előnyősebbé tegye szervezeti } \\
\text { jellemzőit, s ezáltal olyan szilárd egyetemmé váljon, amely piac meghatározó } \\
\text { szereplöjeként van jelen. }\end{array}$ \\
\hline 1998 & Röpke & $\begin{array}{l}\text { Három dolgot jelent: maga az egyetem maga vállalkozóivá válik, az egyetemi } \\
\text { alkalmazottjai, oktatói, munkatársai és a diákok szemléletmódja vállalkozóvá } \\
\text { válik, valamint az egyetem és külső környezet közötti interakciók vállalkozói } \\
\text { minta szerint alakulnak. }\end{array}$ \\
\hline 1999 & Subc & $\begin{array}{l}\text { Jellemzője a szorosabb egyetem-ipari kapcsolatok, nagyobb kutatói felelösség } \\
\text { a külsó finanszírozási források elérésében, valamint vezetésben és } \\
\text { tervezésben menedzseri szemléletmód kialakulása. }\end{array}$ \\
\hline 2002 & rby & $\begin{array}{l}\text { Képes újítani, felismerni és megteremteni a lehetőségeket, csapatban } \\
\text { dolgozni, kockázatot vállalni és reagálni a kihívásokra. }\end{array}$ \\
\hline 2003 & Etzkowitz & $\begin{array}{l}\text { Természetes inkubátor, mely támogatást biztosít az oktatók és a hallgatók } \\
\text { számára új vállalkozások alapítása soráb. }\end{array}$ \\
\hline 2003 & $\begin{array}{l}\text { Jacob, } \\
\text { Lundqvist és } \\
\text { Hellsmark }\end{array}$ & $\begin{array}{l}\text { A vállalkozó egyetem egy olyan kifejezés, melyet olyan egyetemekre } \\
\text { használnak, melyek új infrastrukturális támogatási mechanizmusok széles } \\
\text { körével bírnak mind a szervezeten belüli vállalkozási ismeretek } \\
\text { ösztönzésének mind a vállalkozási ismeretek termékként történő } \\
\text { bemutatásának érdekében. Alapja a piacosítás (személyre szabott } \\
\text { továbbképzési programok, tanácsadási szolgáltatás) és a tudás áruvá alakítása } \\
\text { (szabadalmak, licenciák vagy a hallgatók általindított start-up vállalkozások) }\end{array}$ \\
\hline 2003 & Williams & Nem több mint szolgáltatások értékesítője a tudásipar számára \\
\hline 2005 & Kirby & $\begin{array}{l}\text { Fontos szerepet játszik tudás elöállítóként és terjesztő intézményként } \\
\text { egyaránt. Ebben az értelemben egy vállalkozói egyetemet versenykörnyezeti } \\
\text { túlélőként lehet definiálni, mely olyan általános stratégiával rendelkezik, } \\
\text { melynek célja, hogy minden tevékenységében a legjobban teljesítsen (pl. jó } \\
\text { pénzügyi helyzet, megfelelö hallgatók és oktatók kiválasztása, minőségi } \\
\text { kutatás lebonyolítása), valamint próbál eredményesebb és kreatívabb lenni az } \\
\text { oktatás és kutatás közöttti kapcsolatok kiépítésében }\end{array}$ \\
\hline 2006 & $\begin{array}{l}\text { Guerrero- } \\
\text { Cano, Kirby } \\
\text { és Urbano }\end{array}$ & $\begin{array}{l}\text { A Vállalkozói Egyetem olyan egyetem, amely képes újítani, felismerni és } \\
\text { megteremteni a lehetőségeket, csapatban dolgozni, kockázatot vállalni és } \\
\text { válaszolni a kihívásokra önállóan, célja egy jelentősebb váltás szervezeti } \\
\text { jellegben a jövőbeni ígéretesebb szerkezet elérése érdekében. Más szóval, } \\
\text { természetes inkubátor, mely támogatást biztosít az oktatók és a hallgatók } \\
\text { számára új szellemi, kereskedelmi és egyesült vállalkozások } \\
\text { kezdeményezésében. }\end{array}$ \\
\hline
\end{tabular}

Forrás: Guerrero-Cano et al. (2006), 4.o. alapján saját szerkesztés 
Harmadszor, ilyen kapcsolatok segítségével a felsőoktatási intézmény létfontosságú szerepet játszhat a régiók újjáélesztésében és helyreállításában a gazdasági növekedés elősegítésével, valamint a KKV fejlesztés élénkítésével és fenntartásával (Gordon 2012).

A vállalkozó egyetem definíciójára számos meghatározás született az elmúlt évtizedekben (1. táblázat). A fogalmat elsőként Etzkowitz használta 1983-ban és célja vélhetően az volt, hogy egyrészről megragadja az egyetem és az ipar szorosabb együttmüködésének fontosságát, másrészről hangsúlyozza az egyetem innovációban, illetve gazdasági fejlődésben betöltött egyre jelentősebb - szerepét (Novotny 2011).

Egyértelmü potenciális kapcsolat van az egyetem innovációhoz történő hozzájárulása és a régió fejlesztéséhez való hozzájárulása között (Smith 2007). Ezt a kapcsolatot tükrözi az európai közigazgatás regionális politikájának innovációs és technológiai fejlesztésre, valamint az egyetemi tudás kiaknázására fordított növekvő figyelme az 1980-as évektől (főként az Európai Bizottság támogatásával).

Guerrero-Cano (2006) vállalkozói egyetem fejlődési modelljében elemzi azokat a környezeti tényezőket, amelyek hatással vannak a vállalkozói egyetemek kialakulására, illetve fejlődésére. Emellett a szerzők számításba veszik a mikro- és makrokörnyezeti tényezőket, továbbá a modell outputjait Etzkowitz hármas missziója (oktatás-kutatás-vállalkozói tevékenység) alapján határozza meg (5. ábra).

A szervezeti és irányítási tényezők közé tartozik a világos misszió megfogalmazása, emellett a vállalkozó egyetem víziójának a minőség és vállalkozói kultúra felé kell orientálódnia. Az egyetem számos eszközzel támogathatja a vállalkozásalapítást:

- $\quad$ üzleti (tanácsadás, folyamatos tanulás, ipari partnerek keresése),

- $\quad$ kutatás (K+F infrastruktúra, pénzügyi és humán erőforrások),

- kutatócsoportok (publikációk, tudásáramlás),

- Összekötő irodák (tanácsadás, szerződések),

- technológiai transzfer irodák (szabadalmak, licenciák) és

- $\quad$ inkubátor (tudásintenzív vállalkozások).

Végül, a formális tényezőkön belül, a vállalkozásoktatás során hallgatók, Phd-hallgatók készségeinek, képességeinek fejlesztése történik. 
5. ábra: A vállalkozói egyetem kialakítására és fejlődésére ható tényezők

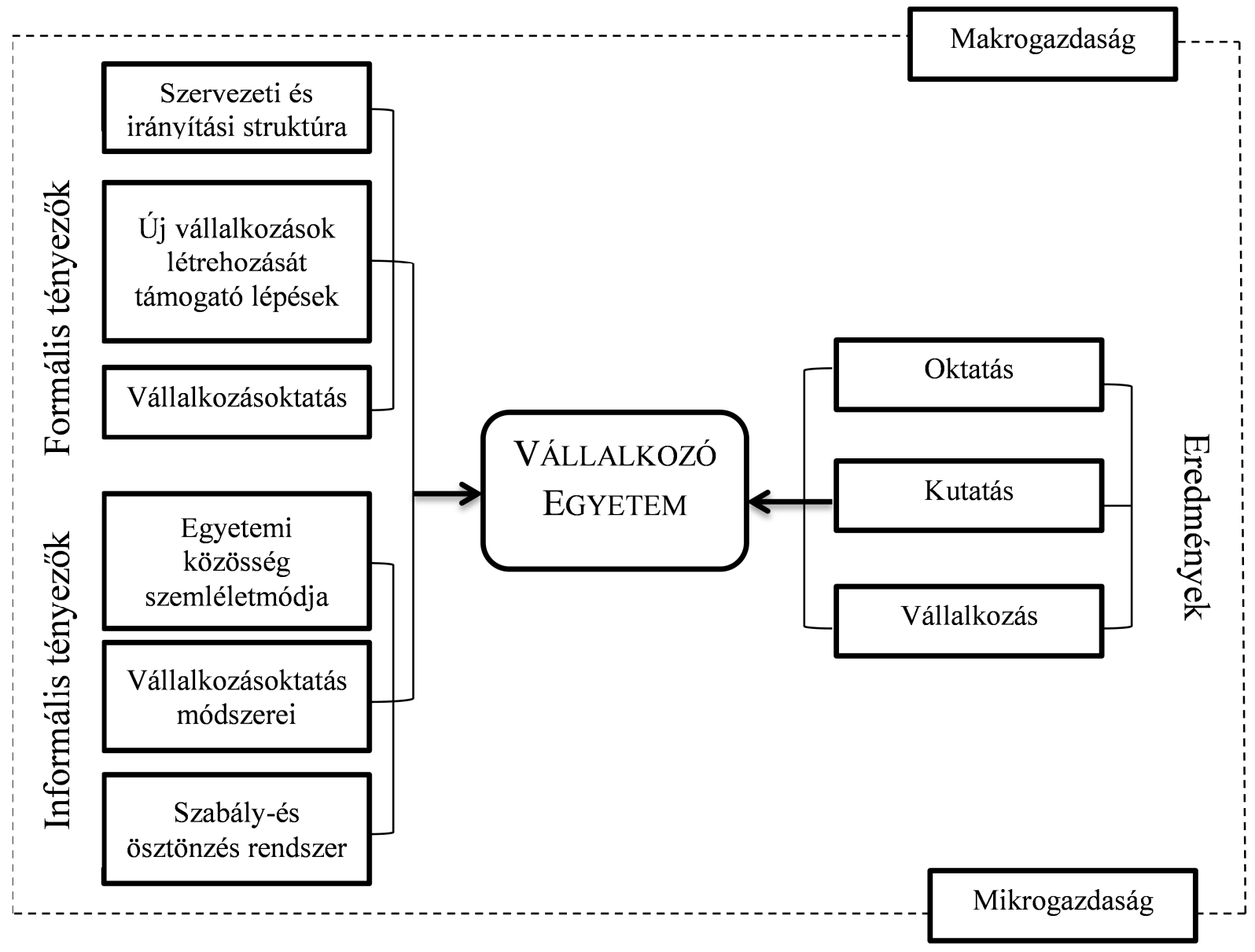

Forrás: Guerrero-Cano et al. (2006), 10.o. alapján saját szerkesztés

A vállalkozó egyetem missziójának teljesítése érdekében a hallgatók, kutatók és karok oktatóinak vállalkozói szemlélet- fejlesztésére van szükség. A vállalkozásoktatás során mind az elméleti, mind a gyakorlati oktatás elengedhetetlen. Emellett a vállalkozó egyetem szabályés ösztönzési rendszerében teret kell kapnia a vállalkozási szemlélet, vállalkozói lét támogatásának, ösztönzésének (Guerrerro-Cano et al. 2006).

Ehhez hasonlóan Etzkowitz és Zhou (2007, 2. o.) is meghatározta a vállalkozó egyetem modell fö elemeit:

- kereskedelmi potenciállal rendelkező kutatóbázis,

- start-up vállalkozások létrehozásának hagyománya,

- vállalkozói (erkölcsi) világkép az egyetemen,

- a szellemi tulajdonjog meghatározásának irányelvei,

- nyereségrészesedés és érdekkülönbségek szabályozása, valamint

- regionális innovációs stratégiában való részvétel. 
Emellett a szerzők szerint a vállalkozó egyetem három fő tulajdonsággal rendelkezik (Etzkowitz - Zhou 2007, 2. o.):

- A vállalkozói tevékenységeket elfogadják és szisztematikusan támogatják.

- Interfész-mechanizmusok, tudatosan épített egyetem-ipari kapcsolatok, pl. technológia-transzfer iroda.

- Számos vállalattól, forprofit szférából érkező szakember, akik bevételt generálnak az egyetemi kutatás és egyéb tevékenységek támogatására.

A Gibb (2013) által kifejlesztett modell a kutatásfinanszírozás interaktív folyamatát mutatja be magán és állami partnerségeken keresztül, mely a kutatás eredményezte fejlesztést és a folyamatból származó tanulást (minden partnert tekintve) helyezi a középpontba (6. ábra).

6. ábra: A Triple Helix modell alapja - felsőoktatás, kormány és magánszféra partnerség

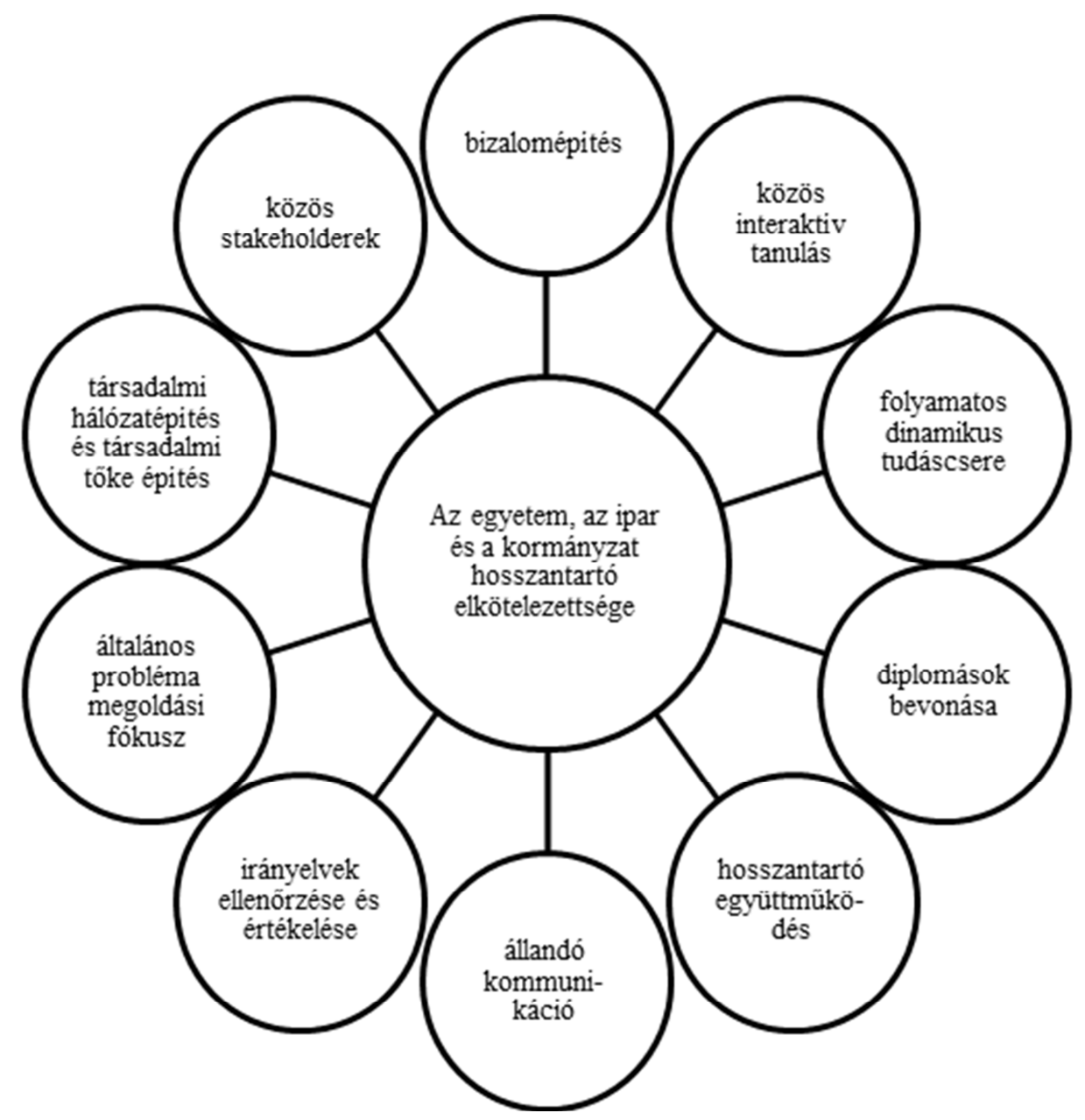

Forrás: Gibb (2013), 20. o. alapján saját szerkesztés 
A modell nem kizárólag regionális jellegű, viszont erőteljes regionális orientációval bír, amikor kis- és középméretủ vállalatokat alkalmaz. Ez azt feltételezi, hogy a vállalkozók az egyetemen fognak dolgozni, míg az egyetemi oktatók a vállalkozásoknál, továbbá a partnerség más finanszírozási formákhoz is kapcsolódhat, valamint egyértelmű koordinációs minták lesznek jellemzőek (Etzkowitz 2008). Az egyetemek most már gyakran rendelkeznek „szakmailag irányított” irodákkal a regionális fejlesztést és tudástranszfert érintő kérdések megoldására. Ezen szervezeti egységek - noha ablakot jelentenek a kinti világra - akadályt is képezhetnek a teljes egyetemi személyzet elkötelezettségét és a tulajdonviszonyokat illetően.

Míg a triple helix modellről folyó tárgyalás szigorúan a tudástranszferre koncentrál, az egyetemeket egyre inkább az erőteljesebb regionális, társadalmi és gazdaságfejlesztési szerep jellemzi (Gibb 2013). Az egyetemek igen fontos szerepet töltenek be egy régióban azáltal, hogy közvetett módon munkahelyteremtő funkcióval is rendelkeznek. Elősegítik az egyes régiók szakképzett fiatalokkal történő ellátását, ezáltal növelve a társadalmi mobilitást. Az oktatási és képzési programjaikon keresztül biztosítják a regionális stakeholderek számára a megfelelő tudás megszerzését. Továbbá szaktudásuk, hírnevük, meglévő infrastruktúrájuk által fontos szerepet játszhatnak a beruházások bevonzásában az adott régióban. Emellett nemzetközi kapcsolataik révén jelentős szerepet töltenek be a külföldi kapcsolatok erősítésében, hálózatok kiépítésében. Gyakran közvetítő szerepet töltenek be a regionális fejlesztés kérdéseinek a központi kormányzat felé történö kommunikációjában a technológiai irányelvek, az oktatás és készségfejlesztés, illetve a versenypolitika területén. Összességében elmondható, hogy központi helyet foglalhatnak el a régió számos aspektusának fejlesztésében.

Clark (idézi Gibb 2013) a vállalkozói egyetemi öt fő összetevőjét nevezi meg:

- erős központi irányító egység a menedzsment csoportok és a tudományos szakemberek felölelése érdekében;

- kibővített fejlesztési periféria, beleértve azon egységek növekedését, melyek az egyetem hagyományos területein túlnyúlnak;

- változatos finanszírozási alap,

- ösztönzött tudományos hátország, a vállalkozói koncepció felé elkötelezett tudományos szakemberekkel; valamint

- integrált vállalakozói kultúra, a változás iránti általános elkötelezettségre építve. 
Gibb (2013) szerint fontos, hogy megkülönböztessük a vállalkozói modellt más felsőoktatásban használatos szervezeti megközelítéstől és fogalomtól, úgy mint az „új managerializmustól”, a „vállalati üzleti modelltől”, a „professzionalizmustól” és a „piacosítástól”. Fontos kiemelni, hogy a vállalkozói szervezeti szemlélet egyikkel sem azonosítható maradéktalanul. A vállalkozói koncepció jóval túlmutat az üzleti és új vállalkozás kontextusán. Eltér, viszont átfedésben lehet, a managerialista fogalom összetevőitől, mivel a vezetés bizonyos stílusával összefüggésbe hozható, viszont a managerializmust kapcsolatba hozták a vállalati bürokrácia számos „szabályával”: erősen formális tervezési folyamatok és információs rendszerek, nagyfokú felelősségre vonhatóság és standard szabályozás, pénzügyi ellenőrzés, rend. A „professzionalizmus” bizonyos mértékig egyértelműen kapcsolatba hozható ezzel, mivel a szakmai vezetők új kultúráját hozza az egyetemekre, ami az akadémikusok esetleges marginalizációjához vezethet. Ez szemben áll a vállalkozói megközelítéssel, amely a már meglévő tudományos testület képességének növelésére helyezi a hangsúlyt a változás levezénylésében.

Végezetül, a vállalkozás fogalma egyáltalán nem áll teljesen rokon értelemben a „piacosítással”. Sem kereskedelmi értelemben, amikor is az egyetem „értékesíti” a knowhow-t, sem pedig az üzleti és egyéb megközelítések alkalmazása értelmében a vásárlók elérésének érdekében, noha időnként mindkét szempont megfelelő elemeit megtestesítheti. Természetesen az egyetem „márkaépítésének”, az arculatépítésnek és a nyilvánosság különböző csatornákon történő elérésének - különösen a médián keresztül - fogalmai fontosak. A vállalkozói szervezetek erőteljes alulról felfelé történő fejlesztési és kezdeményezési fókusszal rendelkeznek, így lehetővé téve a megfelelő szintű cselekvési szabadságot az egyének számára a szervezet minden szintjén.

Gibb (2013) vizsgálta a felsőoktatási intézmények dinamikusan változó környezetét és az ezekre a kihívásokra reagáló paradigmák fejlődését (7. ábra). A szerző célja a környezet fejlődő jellegének jellemzése, amellyel az egyetemeknek kell szembenézniük, egyszerü/összetett és biztos/bizonytalan dimenziókban. Fontos észrevenni, hogy a „kiválóság” fogalma változhat, és ennek függvényében az egyetemek reakciói is elérőek lehetnek. 


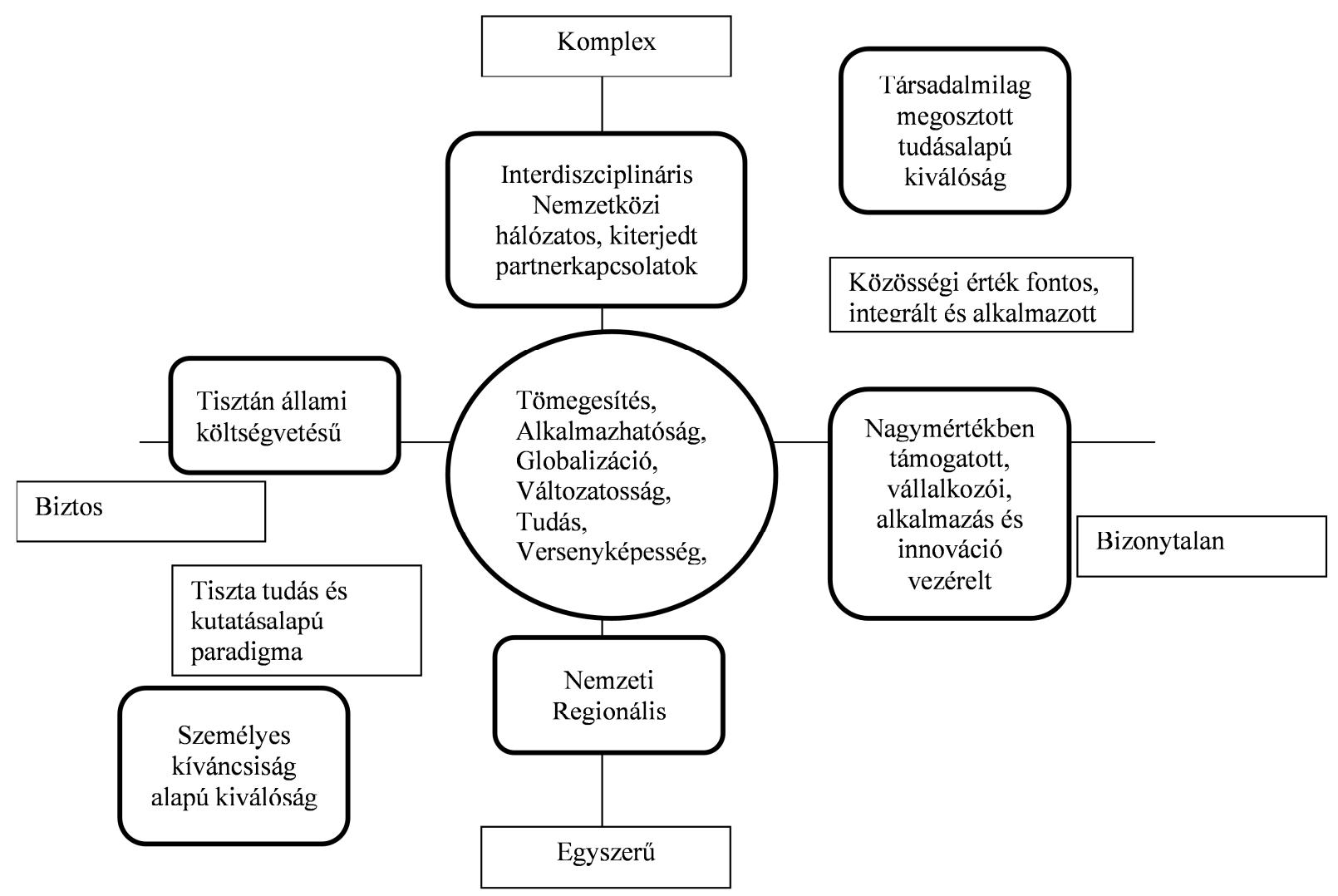

Forrás: Gibb (2013), 13. o. alapján saját szerkesztés

A környezet biztossága csökkent a finanszírozásban történt változások következtében. Elmozdulás történt az egykor szinte univerzális rendszer felől (néhány magánegyetem kivételével, melyek föként az USA-ban fellelhetőek), melyet a szinte teljes központi vagy regionális közfinanszírozás jellemzett, egy olyan helyzet felé, ahol a finanszírozás egyre növekvő hányadát közvetett közforrásokból kell megteremteni mint tandíjak, kutatási ösztöndíjak, helyi fejlesztési pénzek, öregdiák hálózatok, ipari és társadalmi vállalkozások, szerződéses kutatás és filantrópia (Gibb 2013). Míg a kormányzat kulcsszereplő marad a legtöbb országban, fizetési hozzáállása irányítottabb jellegű lett. Így az egyéb finanszírozási források nagyobb arányának szükségességéből eredő bizonytalanság az egyszerübb, biztosabb, „autonóm” környezettől (melyet a közpénz garantál) való elmozdulás nyomásával párosul, melynek keretében kell az individualista kutatást és oktatást megvalósítani. Szükségszerü a közvetlenebb közösségi érték bemutatása. Néhány kormány (például Finnország) közvetlen pénzügyi ösztönzőket nyújt a felsőoktatási intézmények számára a közfinanszírozás emelésének érdekében. 
Mivel a tudásintenzív vállalkozások létrejöttének és akár fejlődésének egyik lehetséges színtere pontosan a felsőoktatási szféra, ezért a tágan értelmezett vállalkozó egyetem egyik alapfunkciója lehet a vállalkozásfejlesztési és vállalkozásoktatási szerepvállalás, ezzel is hozzájárulva az ilyen cégek létrejöttének és fejlődésének támogatásával az adott gazdaság versenyképesség növeléséhez. Habár a vállalkozó egyetemhez nem kapcsolódik szükségszerüen a vállalkozásoktatási tevékenység, a kutatásom során egyértelmüen a vállalkozó egyetem egyik alapfunkciójaként tekintek rá, így a későbbi keretrendszer esetében is meghatározó tényezőként lép elő. Éppen ezért a továbbiakban a vállalkozásoktatásra vonatkozó szakirodalom áttekintésére teszek kísérletet. 


\section{Vállalkozásoktatás, mint a vállalkozó egyetem egyik lehetséges alapfunkciója}

Az egyetemek változó szerepvállalásával összhangban a tudás már nem célként, hanem eszközként jelenik meg, ami azt (is) sejteti, hogy maga az oktatás módszertana is átalakuláson megy keresztül. Éppen ezért a továbbiakban a szakmát is megosztó, egyik központi kérdés köré építem a gondolataimat, azaz részletesebben áttekintem, hogy pontosan tanítható-e, és ha igen, milyen módon a vállalkozás tudománya, milyen letisztult tapasztalatok jelennek meg a nemzetközi szakirodalomban, illetve egyáltalán bővíthetőek-e a vállalkozói kompetenciák a felsőoktatás keretein belül. Ahogy az elöző fejezetben is láthattuk, a vállalkozó egyetem egyik lehetséges alapfunkciójának tekintem a vállalkozásfejlesztési és vállalkozásoktatási szolgáltatásokat. Éppen ezért első körben azt szükséges megvizsgálni, hogy mi is az a vállalkozásoktatás, létezik-e ilyen, illetve milyen jellegzetességei vannak. Azonban mielőtt erre rátérnék, még egy alapvető fogalom tisztázására van szükség, így a következő alfejezetben a vállalkozásoktatás, azaz az „entrepreneurship education” első felével, az entrepreneurship-el foglalkozok.

\section{1. „Entrepreneurship” fogalmának megragadása}

Az „entrepreneurship” misztikus tartalmának megtöltése mindig komoly kihívás elé állította az ezzel a területtel foglalkozó kutatókat, sőt magának a fogalomnak a meghatározására vonatkozóan számtalan tanulmány született az elmúlt években (Bull-Willard 1993, Gartner 1990, Gedeon 2010, Hoskisson et al. 2011, Johnson 2001, Shane-Venkatarman 2000 stb.). Ami biztos, hogy az újabb kutatások szerint a modern „vállalkozói gazdaság” növekedésben betöltött szerepe a - gazdasági folyamatokban megjelenő - tudás megnövekedett fontosságához egyértelműen kapcsolódik (van Stel 2006).

Az alábbiakban bemutatásra kerül néhány definíció (2. táblázat), amely segít megvilágítani ennek a rendkívül komplex fogalomnak a tényleges tartalmát, amely a szemléletmódtól az attitüdön át a „vállalkozói vénához” kapcsolódó tulajdonsághalmazzal együtt a konkrét cselekvésig mindent és bármit jelent egyszerre. 
2. táblázat: Az entrepreneurship definíciója

\begin{tabular}{|c|c|c|}
\hline Év & Szerző(k) & Definíció \\
\hline 1949 & $\begin{array}{l}\text { Cole, idézi } \\
\text { Davidsson et al. } \\
2006\end{array}$ & $\begin{array}{l}\text { Szándékos cselekvés, amely profitorientált vállalkozás elindítására, } \\
\text { müködtetésére és növekedésére vonatkozik. }\end{array}$ \\
\hline 1972 & $\begin{array}{l}\text { Draheim, idézi } \\
\text { Gedeon } 2010\end{array}$ & Új vállalkozás alapítására vonatkozó tevékenység. \\
\hline 1982 & $\begin{array}{l}\text { Vesper, Gedeon } \\
2010\end{array}$ & Egyének és kis csoportok által létrehozott új vállalkozás. \\
\hline 1990 & Gartner & Új szervezetek létrehozása. \\
\hline 1990 & $\begin{array}{l}\text { Stevenson- } \\
\text { Jarillo }\end{array}$ & $\begin{array}{l}\text { Egy folyamat, amely során az egyének lehetőségeket keresnek } \\
\text { tekintet nélkül arra, hogy jelenleg milyen erőforrásokat birtokolnak. }\end{array}$ \\
\hline 2000 & $\begin{array}{l}\text { Shane- } \\
\text { Venkataraman }\end{array}$ & $\begin{array}{l}\text { Jövedelmezö lehetőségek felkutatása és kiaknázása a személyes } \\
\text { „gazdagság” - ennek következményeként a társadalmi „gazdagság” } \\
\text { elérése érdekében. }\end{array}$ \\
\hline 2001 & Johnson & $\begin{array}{l}\text { Egyszerre így definiálható: } \\
\text { - kreatív cselekvés, amely során olyan „,valami” létrejön, amely } \\
\text { - } \text { morábban nem létezett } \\
\text { maga a „,valami” létrehozása olyan lehetőség észlelésére és } \\
\text { - } \text { megragadására épül, amely el volt temetve a környezetben } \\
\text { - mindez magábban rejti az újdonsággal járó kockázatot } \\
\text { - gyakran magában rejti a kreatív rombolást. }\end{array}$ \\
\hline 2003 & $\begin{array}{l}\text { EC } 2003 \text { (Green } \\
\text { Paper } \\
\text { Entrepeneurship } \\
\text { in Europe) }\end{array}$ & $\begin{array}{l}\text { Egy új, vagy meglévő szervezeten belül, gazdasági tevékenység } \\
\text { létrehozására és fejlesztésére irányuló folyamat, gondolkodásmód, } \\
\text { elkötelezettség, amelyben keveredik a kockázatviselés, kreativitás } \\
\text { és/vagy innováció. }\end{array}$ \\
\hline 2006 & $\begin{array}{l}\text { Davidsson et al. } \\
2006\end{array}$ & $\begin{array}{l}\text { Új gazdasági tevékenység létrehozása, amely megjelenik mind az új } \\
\text { vállalkozások létrehozásában, mind a meglévő vállalkozások új } \\
\text { gazdasági tevékenységében. }\end{array}$ \\
\hline
\end{tabular}

Forrás: Saját szerkesztés

Az egyes fogalmak egyfajta elsődleges összegzéseként ki kell emelni, hogy az entrepreneurship egyaránt magában hordozza a kezdeményezőkészséget, a társadalmigazdasági folyamatok megszervezését és a tényleges kockázatviselést. Alapjaiban véve egy gondolkodásmód, egy szemléletmód, egy nézőpont a világról, semmiképp nem szabad leszükíteni a vállalkozás létrehozására és müködtetésére. Az egyes definíciók sok esetben magukban hordozzák azt a problémát, hogy csak egy-egy területre, a fogalom egy-egy aspektusára koncentrálnak, nem pedig a komplex egészre.

Az „entrepreneurship” alapvető eleme a gazdasági folyamatoknak, ami különbözőképpen jelenik meg (Cuervo et al. 2007):

- üzleti lehetőségek felismerésével, felmérésével és kiaknázásával,

- új vállalkozások létrehozásával, valamint meglévő vállalatok megújításával, 
- gazdaság előmozdításával az innováción, munkahelyteremtésen keresztül, valamint a társadalom jólétének növelésével általában.

Ahogy a táblázatból is láthattuk az entrepreneurship kifejezés gyakran „egy új vállalat alapítására" utal, tehát fogalmazhatnánk úgy is, hogy bármely kísérlet új vállalat vagy vállalkozás létrehozására, csakúgy mint az önálló vállalkozás, új üzleti szervezet, illetve egy meglévő vállalkozás kibővítése egyének, egyének csoportja vagy meglévő vállalkozások által (Dreisler 2007). Azonban ez a fogalom kibővíthető annak érdekében, hogy ne csak egy szervezet (vagy alszervezet) létrehozását jelölje, hanem az oktatás által elősegített vállalkozói kultúra szemléletét is, amely nem feltétlenül vezet egy új szervezet/vállalkozás alapításához, hanem egy általánosabb értékhozzáadást jelent, melyet „vállalkozó (szellemü) viselkedésnek" neveznek.

A klasszikus schumpeteri paradigma az olyan vállalkozók tevékenységein alapszik, akik képesek „új utat törni”, új területeket felfedezni, elősegíteni a radikális diverzifikációs törekvéseket, és részben vagy teljesen átalakítani a szervezetet, a termékeket, a technológiát és a piacokat a folyamat során (Schumpeter 1934, idézi Hoskisson et al. 2011). Ezek a schumpeteri tevékenységek vezetnek az olyan időközi lehetőség felfedezéséhez, melyről még elvben sem lehet megállapítani, hogy ténylegesen létezik az innováció létrehozása előtt, valamint ez a körülmény eredményezi a megelőző egyensúlyállapot megzavarását és átalakítását. Másrészt, Kirzner (1973, idézi Hoskisson et al. 2011) új osztrák iskoláról szóló munkájának nyomán, a kirzneri vállalkozás az a mások által még nem észlelt és kiaknázott ismeretek és információk jövedelmező ellentmondásainak, hiányainak, eltéréseinek felfedezéséből fakad. Kirzneri nézőpontból a vállalkozók az aktuálisan hozzáférhető tudást és meglévő lehetőségeket igyekeznek kihasználni, ezáltal növelik az ismereteket az adott helyzetről, idővel csökkentik a bizonytalanság általános szintjét, valamint elősegítik azon piaci folyamatokat, melyek segítenek csökkenteni vagy megszüntetni a vezetők és a követők közötti különbséget.

Alapjait tekintve a schumpeteri vállalkozás, melyben szükség lehet új ismeretekre és merész kreativitásra, ellentétben áll a kirzneri vállalkozással, ahol a stabilitás, a konzisztencia és a következetes tervezés létfontosságú lehet az állandó fejlődéshez.

Összességében tehát jelen tárgyalás keretein belül az „entrepreneurship” tartalmába egyaránt beleértem a gondolkodásmódot és világnézetet éppúgy, mint az ehhez kapcsolódó készségek 
és képességek halmazát. Továbbá a kutatásaim meggyőztek arról, hogy az „entrepreneurship” misztikus tartalmának pontosan az a legnagyobb előnye, hogy mindenki azt az aspektusát emelheti ki belőle, ami számára a legtöbbet jelenti. A fentiekkel összhangban ezt a komplex fogalmat leggyakrabban a „vállalkozókészségnek” feleltethetjük meg, de ettől többet értünk bele: a vállalkozói kompetenciák halmazának teljes skáláját. Ezen rövid fogalmi kitérő után arra a kérdésre térünk át, hogy ezt a „világhoz történő vállalkozói hozzáállást” milyen módon lehet az oktatás keretein belül esetleg javítani.

\subsection{Tanítható-e a „vállalkozás tudománya”?}

Számos tanulmány foglalkozik azzal, hogy tanítható-e az entrepreneurship (Vesper-Gartner 1997, Klofsten 2000, Kuratko 2003, Todorovic 2004, Henry 2005, Bullock 2006). Azok, akik szerint nem tanítható, abból indulnak ki, hogy az egyes emberek vállalkozói tulajdonságokkal születnek (ez az ún. „tulajdonságelmélet”) (Todorovic 2004). Egy másik megközelítés szerint a vállalkozói szerepet gyakran kulturális vagy gyakorlati úton sajátítják el. Ez utóbbi alátámasztja azt a nézetet, hogy a vállalkozókészség oktatáson és képzésen keresztül is befolyásolható. Továbbá, Gartner (1988, idézi Todorovic 2004) meggyőzően érvel amellett, hogy helytelen a vállalkozókészséget a személyes tulajdonságok megközelítése felől vizsgálni. Valójában a vállalkozókészség inkább a magatartásról (amely tanult), mintsem a személyes jellemvonásról (amely örökölt) szól. Mások szerint az vállalkozókészség hasonló a vezetői készségekhez (mint például a kommunikáció, csapatépítés, stb.), amelyet lehet, és kell is, tanítani.

Habár az eredmények nagy része szerint a vállalkozókészség tanítható, a sikeres vállalkozásoktatás nehezen megfogható. Valójában nehéz megfogalmazni, hogy mi a siker kulcsa. A vállalkozókészség taníthatóságát kétségbe vonók szerint a formális vállalkozói képzés kifejezetten hátrányos, az elméleti képzés nem készíti fel a tanulókat arra, hogy kreatív, kockázatvállaló, üzleti készségekkel rendelkező vállalkozókká váljanak. Azonban számos felmérés azt bizonyítja a képzésen résztvevők visszajelzése alapján, hogy a gyakorlati és az elméleti oktatásnak egyaránt hasznát veszik.

Az egyetemi oktatásban jelen lévő tanulási orientációk vállalkozók tanulási igényeivel történő összehasonlítására vonatkozó átfogó elemzésben Gibb (idézi Miltra-Manimala 2008) számos eltérést állapított meg (3. táblázat) 
3. táblázat: Egyetemi kínálat vs vállalkozók tanulási igényei

\begin{tabular}{|l|l|}
\hline \multicolumn{1}{|c|}{ Egyetem/üzleti iskola tanulási fókusza } & \multicolumn{1}{c|}{ Vállalkozók tanulási igényei } \\
\hline $\begin{array}{l}\text { Kritikai értékelés nagy mennyiségü információ } \\
\text { elemzzését követöen }\end{array}$ & $\begin{array}{l}\text { Spontán, ösztönös döntéshozás korlátozott } \\
\text { információ ismeretében }\end{array}$ \\
\hline Maga az információ megértése és felidézése & $\begin{array}{l}\text { Azok értékeinek felismerése, akik átadják/szürik } \\
\text { az információt }\end{array}$ \\
\hline Közös célok feltételezése & $\begin{array}{l}\text { A különböző stakeholderek változatos céljainak } \\
\text { felismerése }\end{array}$ \\
\hline $\begin{array}{l}\text { Az abszolút igazság (személytelen) igazolására } \\
\text { való törekvés az információ elemzésének } \\
\text { segítségével }\end{array}$ & $\begin{array}{l}\text { Az emberek bizalmának és kompetenciájának } \\
\text { megítélésére épülö döntéshozás }\end{array}$ \\
\hline $\begin{array}{l}\text { A társadalom alapelveinek metafizikai } \\
\text { értelemben történő megértése }\end{array}$ & $\begin{array}{l}\text { A társadalom alapelveinek alkalmazására és } \\
\text { azokhoz való alkalmazkodásra történő törekvés }\end{array}$ \\
\hline $\begin{array}{l}\text { A helyes válaszra való törekvés, melyhez (elég) } \\
\text { idő áll rendelkezésre }\end{array}$ & $\begin{array}{l}\text { A legmegfelelöbb megoldás kidolgozása } \\
\text { (gyakran) az idő szorításában }\end{array}$ \\
\hline Tanulás az osztályteremben & Tanulás a tevékenység során és által \\
\hline $\begin{array}{l}\text { Információ gyüjtése szakemberektől és hiteles } \\
\text { forrásoktól a hitelesség érdekében }\end{array}$ & $\begin{array}{l}\text { Információ gyüjtése bárhonnan és } \\
\text { mindenhonnan, valamint gyakorlati hasznának } \\
\text { értékelése }\end{array}$ \\
\hline Írásbeli értékeléssel történő értékelés & $\begin{array}{l}\text { Emberek és események megítélésén keresztül } \\
\text { történő értékelés közvetlen visszacsatolással }\end{array}$ \\
\hline $\begin{array}{l}\text { A tanulás eredményességét tudásalapú vizsgák } \\
\text { teljesítésével mérik }\end{array}$ & $\begin{array}{l}\text { A tanulás eredményességét problémamegoldás, } \\
\text { hibákból való tanulás, valamint hasznos termékek } \\
\text { és szolgáltatások társadalom számára történó } \\
\text { biztosítása alapján mérik }\end{array}$ \\
\hline
\end{tabular}

Forrás: Mitra-Manimala 2008, 53. o. alapján saját szerkesztés

$\mathrm{Az}$ alapvető különbség az, hogy az egyetemek a tudás és ismeretek közlésére koncentrálnak, míg a vállalkozók igénye a megvalósítási készségek kialakítása. A tudásorientált oktatás régre visszanyúló hagyománya a felsőoktatási intézményekben a tanerő útjában áll a készségorientált oktatás kompetenciájának kialakításában. Krueger (2009) megjegyzi, hogy az igazi probléma-alapú tanulás (problem-based learning) sokkal több, mint a cselekvés alapú tanulás (learning-by-doing), hiszen a tanulók rá vannak kényszerítve arra, hogy strukturálják a problémát, valamint a szükséges tudást és készségeket. Ezáltal a vállalkozásoktatás során a probléma-alapú tanulás legfontosabb értéke az, hogy orientálja a tanulókat a válaszkeresés felöl a kérdésfeltevés felé.

A vállalkozásoktatás számos kihívással néz szembe, Charharbaghi és Willis (idézi Solomon 2007) szerint a vállalkozókat nem lehet gyártani, csak felismerni. Curran és Stanworth (1989) úgy gondolják, hogy a vállalkozásoktatás nem költséghatékony. Előbbieknél kissé árnyaltabban Garavan és O’Cinneide (1994) azt hozza fel problémaként, hogy a téma szakirodalma még meglehetősen szükös és nem áll rendelkezésre egy megfelelően kidolgozott keretrendszer, letisztult elméleti háttér, amely az ilyen jellegü programok alapját képezhetné. 
A vállalkozás tudományának taníthatósága mellett érvelők közül Gorman és szerzőtársai (1997) szerint alátámasztható, hogy a vállalkozás tanítható, vagy legalábbis ösztönözhető a vállalkozásoktatás segítségével. Senki nem vitatja a tényt, miszerint az orvos-, a jog- vagy a mérnöki tudományok taníthatóak, mégis vannak olyan orvosok, jogászok és mérnökök, akik tehetségesek, és vannak, akik nem. Hasonlóan lehet érvelni a vállalkozástudomány és vállalkozók esetében is (Fayolle et al 2008, Fayolle 2007).

Bizonyos mértékben ezek a gondolatok mindig visszanyúlnak a fő kérdésekhez, melyet egy oktatónak fel kell tennie: Mit? Kiknek? Milyen eredmények érdekében?

A vállalkozásoktatás hagyományos módjának (azaz csak elmélet) kiindulópontja az, hogy az oktatás alapja egy megfelelő elméleti képzés (Todorovic 2004). Az elmélet egyértelmúen fontos és elengedhetetlen, hiszen egy elméleti keretet nyújt, azonban véleményem szerint ez a vállalkozásoktatás csupán egy szelete. A vállalkozásoktatásnak túl kell lépnie az elméleten ahhoz, hogy gyakorlati szempontból képes legyen a tanulókat felkészíteni a „való világ” környezetére. Hasonlóan, egy Svédországban végzett tanulmány azt a következtetést vonta le, hogy a vállalkozói képzési programnak gyakorlatközpontúnak (azaz alkalmazottnak) kell lennie, miközben megtartja az elméleti elemek hozzáadott előnyét (Klofsten 2000).

Megfigyelték, hogy a vállalkozók az ötletekkel történő kísérletezés és a konkrét cselekvések révén tanulnak a legjobban (Todorovic 2004). Azok a programok, amelyek keretein belül az oktatási intézmények igyekeznek olyan környezetet létrehozni, amely modellezi a tényleges vállalkozói környezetet sokkal eredményesebbek. Mivel az „entrepreneurship” elősegítése még mindig fiatal terület, még nagyobb szükség van arra, hogy a vállalkozásoktatás az elméleti alap mellett ún. dinamikus komponenst is tartalmazzon. Todorovic (2004) szerint ez a dinamikus komponens jelentheti az oktatási kontextust, amelyre hatással van a tanulói tevékenység, valamint amely a „való élet” vállalkozásaihoz hasonló arányban nő és fejlődik. A dinamikus komponensre egyik példa az esettanulmány, amely esetében nem feltétlenül egyetlen konkrét, jól megfogható helyes válasz adható, hanem a tanulók együttes, összehangolt tevékenysége határozza meg, mi is a helyes válasz.

Kezdetekben a dinamikus elem nem volt megfelelő (vagy egyenesen hiányzott) a vállalkozásoktatási tevékenységből és az egyetemi környezetből (és az intézményi kultúrából) egyaránt. Az egyetemek számára ezért nehéz ennek a problémának a megoldása, pusztán a kurzusok tantervének megváltoztatása nem elegendő. Maga az entrepreneurship egy 
dinamikus területet, amely folyamatosan változik az idő múlásával. Ezt tükrözte az a megfigyelés, miszerint a „való életbeli” vállalkozókon ott a nyomás, hogy gyorsan reagáljanak és minél előbb találjanak megfelelő megoldásokat a folyamatos kihívásokra, miközben gyakran számos komoly korlátozó tényezőkkel kell szembenézniük. Mivel az entrepreneurship egy igen felkapott kutatási terület napjainkban, így az elméleti ismeretanyag is egyre inkább bővül. Ahogy az elméleti anyag bővül, úgy bővül a vállalkozásoktatási tevékenység statikus komponense is (8. ábra). Jelenleg, mivel a modern vállalkozáselmélet és különösen a vállalkozásoktatás még mindig fejlődésének korai szakaszában jár, a dinamikus összetevőnek nagyobb mértékben kell jelen lennie, mint a statikus összetevőnek a vállalkozásoktatásban.

8. ábra: A vállalkozásoktatás fogalmi kerete a vállalkozás-orientált egyetemen

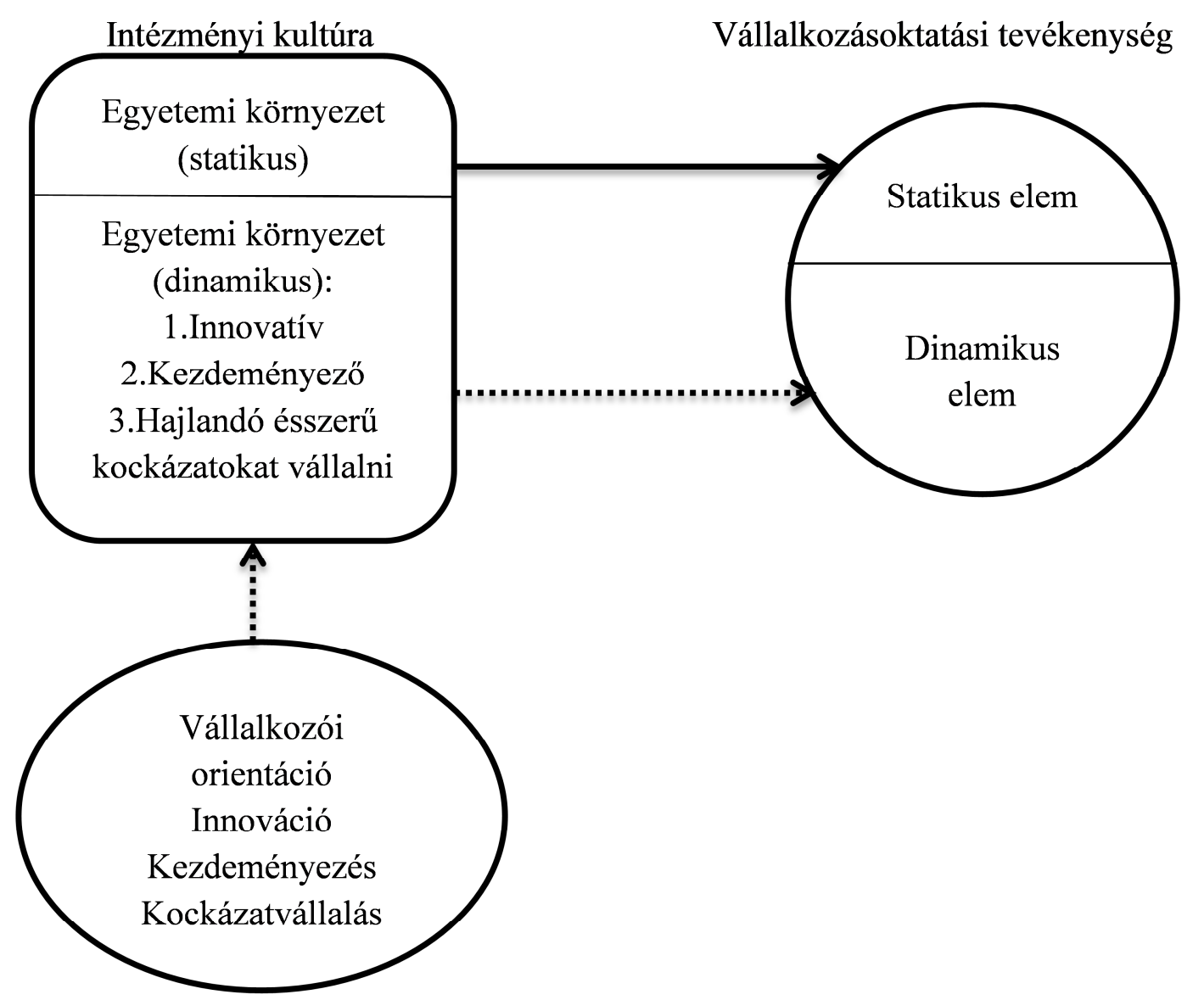

Forrás: Todorovic 2004, 25. o. alapján saját szerkesztés

Todorovic (2004) javasolt egy keretrendszert a vállalkozásoktatásra vonatkozóan. A vállalkozói orientáció növeli a dinamikus komponenst az egyetemi kultúrában (azaz a képen a pontozott vonal), amely hatással van a vállalkozásoktatási tevékenységre is, ezáltal 
hozzájárulva a vállalkozásoktatás dinamikus komponenséhez. A statikus komponens azonban a vállalkozásoktatási feladat része marad. Azaz a valóban eredményes vállalkozásoktatás sokkal többről szól, mint a kurzus tanterv összeállítása. Klofsten (2000) szerint ahhoz, hogy az egyetem hatékonyan oktassa az entrepreneurship-et, biztosítania kell a vállalkozó szellemü kultúra létrehozását és fenntartását az egyetem egész területén. A szervezeti kultúra jelentős szerepet játszhat a képzési programok eredményességében. A hallgatói visszajelzésekböl arra következtetettek, hogy a hallgató vállalkozók nagyobb hasznot húznak az egyetemi környezetből és a kulturális orientációból, mint a kurzus tartalmából (Todorovic 2004).

Az előző fejezetben ismertetett folyamatok következtében napjainkban az egyetemek komoly próbálkozásokat tesznek arra, hogy rugalmasabbá, innovatívabbá és főként kezdeményezőbbé váljanak - érdemi szerepet betöltve ezzel a regionális gazdaságfejlesztésben is. Egy innovatív és kezdeményező egyetem jobban fel van készülve a körülötte lévő világ változásaira történő reagálásra, amely azt jelenti, hogy ezen jellemzők a dinamikus egyetemi kultúra elemei. Az állítás, miszerint az egyetemi kultúra dinamikus komponenssel rendelkezik magában hordozza egy statikus összetevő létezését is (Klofsten, 2000). Klofsten (2000) szerint, aki mindkét komponens létezését is azonosította, az egyetemek a kompetenciák mindkét típusával kell, hogy rendelkezzenek annak érdekében, hogy hatékony vállalkozásoktatást valósítsanak meg. Az eddigiek ismeretében elmondhatjuk, hogy a vállalkozáselmélet oktatása nem jelent átfogó vállalkozásoktatást. Egy analógiával élve, egy ember, aki alapos ismeretekkel rendelkezik a repülésről, nem feltétlenül pilóta. Ehelyett ennek az embernek repülőgépet kell vezetnie egy oktató segítségével minimum óraszámban (amely a dinamikus elem), mielőtt jogot szerez a pilóta jogosítványra. Hasonlóképpen, egy vállalkozónak meg kell szereznie a dinamikus tartalomban található kompetenciákat, mielőtt képessé válik egy valós idejü, nagymértékben komplex vállalkozói környezetben történő müködésre.

Todorovic (2004) keretrendszerét összegezve elmondható, hogy az egyetemi intézményi kultúra statikus és dinamikus komponensekből áll, melyek egyaránt közvetlen hatást gyakorolnak a vállalkozásoktatási tevékenységre. Az egyetemek, a stabil intézményi jellegük miatt, sajnos a fentiek ellenére jellemzőbben oktatnak statikus ismeretanyagot. Sajnos mivel a vállalkozásoktatás még mindig fejlődő terület ez az ismeretanyag önmagában nem elégséges a jövő vállalkozóinak képzéséhez. Annak érdekében, hogy az egyetemek átfogó vállalkozásoktatást biztosítsanak, a dinamikus komponenst is tartalmaznia kell. Ez 
összeegyeztethetetlen a legtöbb egyetem jelenlegi kultúrájával, gyakorlataival és struktúráival. Következésképpen számos egyetemi kísérlet a jövő vállalkozóinak képzésére korlátozott sikert ért el.

Jack és Anderson (1998, idézi Henry et al. 2005) szerint a „vállalkozás tudományának” tanítása rejtély, hiszen a tényleges vállalkozói folyamat mủvészetet és tudományt egyaránt magában foglal. A ,tudomány” része, amely az üzleti és menedzsment gyakorlati készségeket jelenti, taníthatónak bizonyul hagyományos pedagógiai módszerek alkalmazásával. Azonban a „művészet”, amely a vállalkozókészség kreatív és innovatív jellemzőire vonatkozik, nem tanítható ily módon.

Ez a szemlélet megegyezik a Shepherd és Douglas (1996) nézeteivel, akik alátámasztják a művészeti és tudományos elemek oktatásának szükségességét. Valóban, mivel a vállalkozó szellem nem mindenkiben fedezhető fel, illetve felélesztésre és elősegítésre szorulhat, az üzleti oktatásnak nem csak a különböző üzleti tudományokat kellene tanítania, hanem a vállalkozói lét lényegét is. Számukra azonban a művészet és a tudomány közötti rés sokkal szélesebb. A tudományt szelektívként, elemzőként, szekvenciálisként és állandóként jellemzik, míg a művészetalkotó, provokatív és korlátlan. A szerzők nem állítják, hogy a müvészet nem tanítható, csupán a jelenlegi oktatási gyakorlatban méltánytalanul elhanyagolják ezt a területet.

Az üzleti iskolák vállalkozóvá váláshoz történő hozzájárulásának vizsgálatában Shepherd és Douglas (1996) rámutat arra, hogy sok vállalkozásoktató logikus gondolkodást tanít, amikor valójában vállalkozói gondolkodást kellene, és amellett érvelnek, hogy a logikus gondolkodás helytelen és megvalósíthatatlan válaszokhoz vezethet. A vállalkozásoktatók számára kihívást jelent az olyan innovatív tanulási módszerek megtalálása, amelyek egybeesnek a potenciális vállalkozók igényeivel.

Miller (1987, idézi Henry et al. 2005) szintén elválasztja az „entrepreneurship” tanítható aspektusait a nem tanítható aspektusaitól. Véleménye szerint az „entrepreneurship” nem minden aspektusa tanítható, és az oktatók nem képesek vállalkozókat létrehozni, ahogy nem tudják a vállalkozói siker receptjét megalkotni. A szerző szerint azonban az oktatók ismereteket nyújthatnak az új vállalkozás elindításához szükséges szigorú elemző technikákról és technikák korlátainak ismertetéséről. Továbbá megállapítja, hogy a 
vállalkozói tulajdonságok egy részét, mint például az önbizalmat és a kitartást, nem lehet teljes mértékben a tanteremben elsajátítani.

Kuratko (2003) szerint az vállalkozókészség, vagy legalábbis néhány aspektusa üzleti oktatók és/vagy képzési szakemberek által tanítható a vállalkozói tevékenység megkezdése előtt, alatt és után is. Természetesen nem mindenki fogadja el a vállalkozásoktatás ezen egyszerü alap megállapítását sem. Így például Johannison a következőképpen érvel: „az egyének megtanítása arra, hogy ne csak vállalkozóbb szellemüekké, hanem üzletemberekké váljanak...egy olyan kihívás, amely időben és méretben is túlmutat a tudományos üzleti iskolák képességein" (Matlay 2008). Továbbá, kiegészítéseként Rae (1997) megállapítja, hogy „,...az üzleti iskolákban hagyományosan oktatott készségek alapvetőek, de nem elégségesek a sikeres vállalkozóvá váláshoz".

Figyelembe véve az ellentétes véleményeket, nem meglepő, hogy folyamatos és elhúzódó vita folyik arról, hogy az egyetemek valóban jelentősen hozzá tudnak-e járulni a gazdaságban működő vállalkozói állomány számához és minőségéhez. A folyamatban lévő vita ellenére a kínált vállalkozásoktatási programok száma és választéka jelentősen nőtt Európában, Ázsiában, Észak-Amerikában, Ausztráliában és Új-Zélandon (Kuratko 2003). Még az USAban is, ahol a vállalkozásoktatás hosszú és jól megalapozott hagyománnyal rendelkezik, óriási növekedés történt a kínált kapcsolódó kurzusok számában az 1990 és 2005 közötti időszakban. Az 1990-es évek közepén az uralkodó nemzetközi trendek és a piacok növekvő globalizációja ösztönzőként és motivációként szolgált a döntéshozók számára az Egyesült Királyságban az ipar és a felsőoktatás kapcsolatának, valamint a vállalkozásoktatás helyzetének értékelésében.

A vállalkozásoktatással kapcsolatos programokat illetően kritikaként jelenik meg, hogy az ilyen programok gyakran azonosnak tekintik a tényleges vállalkozóvá válást az új vállalkozás létrehozásával és/vagy kisvállalkozások menedzsmentjével, emellett az vállalkozóvá válásról és vállalkozásról oktatnak, ahelyett, hogy a vállalkozóvá válás érdekében oktatnának. Továbbá ritkán helyezik a sikeres vállalkozó készségeinek, tulajdonságainak és magatartásának kialakítását a középpontba. A vállalkozóvá válás elősegítésének és új vállalkozás létrehozásának szentelt tantervek és programok közelmúltbeli növekedése és fejlesztése figyelemre méltó. Nyilvánvalóvá válik, hogy a „vállalkozás tudománya”, vagy 
legalábbis bizonyos aspektusai, tanulhatóak. Az üzleti oktatók és szakemberek túlléptek azon a mítoszon, hogy a vállalkozónak születni kell és nem kialakítható (Kuratko 2003).

Gorman és szerzőtársai (1997) vállalkozásoktatásról szóló tanulmányokat vizsgáltak 19851995 között a következő folyóiratokban: Frontiers of Entrepreneurship Research, Journal of Small Business and Entrepreneurship, Entrepreneurship Theory and Practice (American Journal of Small Business), Journal of Small Business Management, Journal of Entrepreneurship and Regional Development, International Small Business Journal and Journal of Business Venturing. Céljuk az volt, hogy megvizsgálják a tudomány jelen állását, illetve azt, hogy a jövőre vonatkozóan milyen javaslatok fogalmazhatók meg. A szerzők a következő főbb következtetéseket vonták le a kutatásaik alapján:

- A vizsgált empirikus tanulmányok többsége alapján a vállalkozás tanítható, vagy legalábbis ösztönözhető, a vállalkozásoktatás segítségével (aktív módszerek által).

- Különbséget kell tenni az „entrepreneurship”, az „enterprise” és „small business menedzsment” oktatás között, illetve ezeket el kell határolni a hagyományos menedzsmentoktatástól.

- A kurzusok hatékonyságával kapcsolatban számos fenntartással bírtak: néhány minta torz volt, mivel a hallgatókat nem szürték a vállalkozói hajlamukat illetően, mielőtt felvették volna a vállalkozástudományi kurzust; a legtöbb tanulmány keresztmetszeti volt; a kulcsváltozók mérését nagyrészt ön-jelentésekre alapozták; kevés kutatási felépítés tartalmazott elő- és utótesztelést egyaránt; valamint szinte egyik sem rendelkezett egy olyan mögöttes fogalmi keretrendszerrel, melyből a hipotézisek származtak.

Amikor az 1980-as évek közepén a felsőoktatásban megvalósuló vállalkozásoktatás kezdett előtérbe kerülni, Peter Drucker (1985, idézi Lange et al. 2011) ezt mondta: „A vállalkozói rejtély? Nem varázslat, nem rejtély, és semmi köze a génekhez. Tudomány. És mint minden tudományág, tanulható." És ha tanulható, feltételezhetően tanítható. Húsz évvel később, amikor a „entrepreneurship”-et több mint 1600 amerikai egyetemen és föiskolán tanították, Drucker megállapítását Kuratko (2003) idézte meg a következőképpen: „Egyre inkább nyilvánvaló, hogy a vállalkozást, illetve bizonyos aspektusait, meg lehet tanítani. Az üzleti oktatók és szakemberek túlmutatnak azon a mítoszon, miszerint vállalkozónak születni kell, nem lehet kifejleszteni." 
Drucker nézeteivel ellentétben, miszerint a gének nincsenek kapcsolatban a vállalkozóvá válással Nicolaou és Shane (2009) a közelmúltban molekuláris genetika vizsgálatokat végeztek annak érdekében, hogy bebizonyítsák, hogy az egyén vállalkozói hajlamát a szülöi DNS már a fogamzásnál eldönti. A szerzők szerint az egyének veleszületett vállalkozói tulajdonságokkal születnek, néhányuk többel, mint mások. A szerzők szerint négy egymást kiegészítő módon lehet hatása a géneknek a vállalkozói aktivitásra (Nicolaou - Shane 2009):

- A gének hatással lehetnek az agy kémiai mechanizmusaira, amely növeli annak valószínűségét, hogy vállalkozói tevékenységei folytatnak majd

- A gének fogékonyabbá teszik az embereket, hogy fejlesszék személyes tulajdonságaikat, úgy, mint extroverzió, belső locus of control, amelyek hatással vannak a vállalkozói tevékenységre.

- A gének a többieknél érzékenyebbé tehetik az embereket a környezeti ingerek iránt, amely szintén ösztönzi a vállalkozói tevékenységet.

- Végül, a gének befolyásolhatják azt, hogy az egyén vállalkozási tevékenységre előnyösebb környezetnek legyen kitéve.

A szerzők szerint a vállalkozói génekkel született gyermek fejlődik, a szocializáció és az oktatás fokozza vagy gátolja a genetikai adottságokat. A gyermekkori szocializáció nagy részét a szülő végzi. Azok a szülők, akik vállalkozók, napi kapcsolatot biztosítanak gyermekeiknek az üzleti világgal, és így a gyermekek vállalkozói tudatosságra tesznek szert. Nyilvánvaló módon a családi vállalkozásokban már gyerekkorban szerzett tapasztalatok hatással lehetnek a későbbi vállalkozói tevékenységre. A szerzők azonban nem álltak elő közvetlen empirikus bizonyítékkal a genetikai elméletük alátámasztására. Mindamellett állításuk szerint a környezeti tényezők szintén meghatározóak lehetnek abban, hogy a magzat vállalkozó lesz-e felnőtt korában, és az egyik ilyen meghatározó tényező: az oktatás. Következésképpen, amennyiben Nicolaou és Shane koncepciója igaz, akkor a vállalkozók születnek, sőt oktatással és még jobb vállalkozókká válhatnak. Ahogy Kuratko (2003) fogalmaz, ,a vállalkozás taníthatósága elavult kérdés.”

Megvizsgálva a schumpeteri és kirzneri vállalkozástudományi definíciókat, lehetséges a potenciális vállalkozók képzése a lehetőségek felismerésére, azonban nehéz megtanítani a lehetőségek kialakításának művészetét. Továbbá, a kirzneri vállalkozástudomány (lehetőség felismerése) tanítható, de a schumpeteri vállalkozástudomány nem (lehetőség kialakítása). Saks és Gaglio (2002) hozzátette, hogy míg megtanítható a vállalkozástudományi programok 
résztvevőinek a lehetőségek értékelése, a veleszületett képesség a lehetőségek felismerésére nem tanítható. A vállalkozásoktatás csak szemléltetni tudja a sikeresség folyamatát, viszont vállalkozót nem tud létrehozni, mivel alapvetően az egyén felelős saját sikeréért.

Az egyes kurzusok, programok minősége mellett igen fontos szempont lehet az, hogy azokra hallgatókra, akik már eleve vállalkozói szándékkal rendelkeznek és emiatt választották az adott kurzust, illetve programot bizonyosan nagyobb hatást gyakorolnak a vállalkozásoktatás egyes formái.

\subsection{Vállalkozásoktatás}

Az utóbbi években a vállalkozóvá válás elősegítésének kérdése egyre inkább középpontba került. Az egyetemről kirajzó értelmiség a jövő vállalkozásainak záloga, olyan dinamikusan fejlődő és innovatív területeken, mint pl. az információs technológia vagy a biotechnológia. Valójában, a sikeres egyetemek az USA-ban kihangsúlyozzák az oktatási intézmények mint a high-tech start-up vállalatok katalizátorai fontos szerepét: rendkívül szemléletes példa, hogy ha a négyezer, az MIT diplomásai és tanári kara által alapított, cég egy önálló nemzetet alakítana, akkor ezek a cégek a nemzetet a világ 24. legnagyobb gazdaságává tennék (LüthjeFranke 2002). Hasonlóan, a Stanford Egyetem a Silicon Valley több élen járó cégével kapcsolatban van (Pfeiffer 1997). A különbözö európai régiókban végzett gazdasági tanulmányok azt mutatják, hogy az egyetemek hatása a cégek létrehozására az USA-n kívül is megfigyelhető (Lüthje-Franke 2002). A vállalkozásoktatás megteremtése 1938-ra nyúlik vissza és Shigeru Fujii nevéhez kötődik (McMullan 1987) és napjainkra a vállalkozásoktatás a gazdasági stratégiák szerves részévé vált, illetve a gazdasági felsőoktatási intézmények meghatározó részének kínálatában jelen van (Matlay 2005). A gazdaság versenyképességében egyre jobban felértékelődik a felsőoktatás versenyképessége (Barakonyi 2010). Az egyetemek szerepe is folyamatosan változik, alkalmazkodik a megváltozott környezethez, feladatokhoz (Barakonyi 2004), illetve az egyetemek irányításában, finanszírozásában, képzési rendszerében bekövetkező változásokhoz (Inzelt 2010). A szolgáltató egyetem jelenség egyre jobban felértékelődik (Schwartz 2006), egy lehetséges szolgáltatás a vállalkozásoktatás is. Az egyik legnagyobb kihívás az, hogy az egyetemek a „elefántcsonttorony” státuszból a ,vállalkozói egyetem" státusz felé mozduljanak el. Még az üzleti iskoláknál is reális veszély, hogy az elmélet és a módszertan fetisizálása mind távolabbra sodorja őket a tényleges üzleti gyakorlattól (Barakonyi 2009). 
Az Európai Unió is kitüntetett figyelmet szentel a vállalkozásoktatásnak, amit az is bizonyít, hogy megszületett az „Entrepreneurship 2020 Akcióterv” (EC 2013), amely három fő pillérre épül: vállalkozói oktatás és képzés, vállalkozói környezet kialakítása, valamint társadalom problémás csoportjainak támogatását (új vállalkozói generációról történő gondoskodás). Az első pillérhez kapcsolódva a Bizottság a következőket szeretné megvalósítani:

- A pán-európai vállalkozói oktatási kezdeményezés kifejlesztése, amely a meglévő európai és nemzeti szakemberek tudását és tapasztalatát kívánja összekapcsolni annak érdekében, hogy elemezzék a képzési gyakorlat hatékonyságát, megosszák az ismereteket és tapasztalatokat, közösen fejlesszék a módszertant és az Unió különböző tagországaiban dolgozó szakemberek „peer mentoring” tevékenységét, azaz az egymástól való tanulást segítsék.

- A tagországok együttmüködésének erősítése a vállalkozásoktatás minden tagországba történő bevezetése során.

- Az OECD-vel együttmüködve keretrendszer kidolgozása, amely ösztönzi a vállalkozói iskolák és szakképző intézmények fejlődését.

- A vállalkozói oktatás informális környezetben történő értékelésének támogatása.

- A vállalkozói egyetem keretrendszerének disszeminációja

- Az egyetemvezérelt vállalkozásalapítás (spin-off) és az egyetem-vállalkozás ökoszisztéma támogatása

A felsorolt törekvésekből jól látszik, hogy a következő időszakban kiemelkedő szerepet kap a vállalkozásoktatás fejlesztése és bevezetése az Európai Unióban. Továbbá a Bizottság felkéri a tagállamokat (EC 2013):

- a vállalkozókészséget, mint kulcskompetenciát építsék be az alap-, közé-, felső- és felnőtt képzés tanterveibe 2015-ig,

- biztosítsák a fiataloknak, hogy legalább egy vállalkozói gyakorlati tapasztalatot szerezzenek tankötelesség évei alatt (pl. mini-vállalkozás menedzselése, valamint vállalkozói és társadalmi projektekben történő részvétel),

- az egyes tagállamok „nemzeti foglalkoztatási terveivel” összhangban és a Strukturális Alapok által biztosított erőforrások segítségével megerősíteni a fiatalok és felnőttek vállalkozói képzését, 
- a fiatalok részére vállalkozói tanulási modulok támogatása, az Európai Ifjúsági Garanciarendszer bevezetése ${ }^{2}$.

Az elmúlt évtizedekben felértékelődött a vállalkozások helyi gazdaságfejlesztésben betöltött szerepe (Wennekers - Thurik 1999, Vilmányi-Kovács 2008), illetve általánosságban is az egyetem-ipari kapcsolatok különféle megvalósulási formái (Vilmányi 2011). Továbbá kitüntetett figyelmet kapnak a magas hozzáadott értékü termékeket és szolgáltatásokat létrehozó spin-off vállalkozások (Imreh et al. 2013). Éppen ezért a sikeres vállalkozások létrejöttének egyik eszközeként megjelenő vállalkozásoktatás is egyre hangsúlyosabb szerepet kap. Az Európai Bizottság (2013) szerint Európának jelen gazdasági helyzetben még több vállalkozásra van szüksége ahhoz, hogy a visszatérjen a növekedési pályára, valamint a foglalkoztatás magasabb szintjét érje el. A lakosság vállalkozó készség minél magasabb szintje (,vállalkozói-tőke”) a munkahelyteremtésben és a gazdasági növekedésben egyaránt komoly szerepet tölt be, hiszen új munkahelyeket, új piacokat hoz létre, miközben a gazdaságot is versenyképesebbé, innovatívabbá teszi. Az Európai Bizottság éves növekedési jelentése (2013) hangsúlyozza az üzleti környezet fejlesztésének versenyképesség növekedésben betöltött fontos szerepét az Európai Unióban. A Jelentés öt prioritást jelöl meg, amelyek közül a harmadik prioritáson belül jelenik meg az üzleti környezet, oktatás fejlesztésének szükségessége (EC 2013):

1. Differenciált, növekedésbarát költségvetési konszolidáció elősegítése

2. A normális hitelnyújtás visszaállítása a gazdaságban

3. A jelenlegi és jövőbeni növekedés és versenyképesség ösztönzése

4. A munkanélküliség kérdésének és a válság társad almi következményeinek kezelése

5. A közigazgatás modernizálása

Számos irányból közelítik a vállalkozásoktatást, emellett több elnevezés is létezik rá vonatkozóan. A „vállalkozásoktatás” (entrepreneurship education) kifejezés általánosan használt az USA-ban és Kanadában, viszont kevésbé volt elterjedt Európában az 1980-as évek elején. Az Egyesült Királyságban és ír kontextusban az előnyben részesített kifejezés a „vállalati oktatás” (enterprise education) volt, de az 1990-es évek elejére a „vállalat” (enterprise) fogalma fokozatosan beleolvadt a „vállalkozástudomány” fogalmába. Jones és

\footnotetext{
${ }^{2}$ Fiatalkori munkanélküliség leküzdésére irányuló új megközelítés, amely garantálja, hogy minden 25 év alatti fiatal az iskolai tanulmányai befejezését vagy a munkanélkülivé válását követő 4 hónapon belül színvonalas állásajánlatot kaphat, illetve további oktatásban, gyakorlati, valamint gyakornoki képzésben vehet részt (EC 2013).
} 
Iredale (2010) szerint, a vállalati oktatás célja maximálisan kihasználni a vállalakozói készségek, viselkedésmódok és tulajdonságok fejlesztésének lehetőségeit a fiatalok esetében, azzal az elvárással, hogy ezeket kihasználják, alkalmazzák és fejlesztik a jövőben, bármilyen pályát is választanak. Ezzel szemben a vállalkozásoktatás célja inkább az egyének ösztönzése a vállalkozás elindítására.

A különböző megközelítések és definíciók ellenére azért elmondható, hogy a vállalati-, az üzleti- és akár a vállalkozásoktatási tevékenység egyik végső célja egyaránt a független vállalkozás létrehozásának és sikeresebb működtetésének ösztönzése (Imreh-Tóth et al. 2011). A vállalkozásoktatás elsődleges célja az új vállalkozások sikeres kialakításának támogatása. Itt fontos kiemelni, hogy a vállalkozástudományi programok sikerét nem lehet pusztán a végzett hallgatók számával mérni, hanem sokkal inkább az általuk létrehozott vállalkozások társadalmi-gazdasági hatásával. Olyan kérdések, mint pl. a létrehozott vállalkozások száma, a létrehozott munkahelyek száma, a kialakított cégek típusai és a cégek teljesítményének növekedése a gazdasági növekedés szempontjából létfontosságúak (Sternberg - Wennekers 2005, Wong et al. 2005).

Amint az előző fejezetben is tárgyaltam, az egyetemek egyre inkább középpontba kerültek az elmúlt években, hiszen nagyobb mértékben kell, hogy megosszák a tudást a társadalom más produktív szektoraival, mint az megszokott volt az európai hagyományban (Etzkowitz 2003). Kiemeltem, hogy a triple helix modellel kapcsolatban a kutatók rámutattak, hogy a vállalkozói egyetem egyesíti az oktatást, a kutatást és gazdasághoz való hozzájárulást, különösképpen helyi szinten (Martin - Etzkowitz 2000, Röpke 2000). Amikor az egyetem vállalkozó egyetemmé válik, megváltozik státusza az innovációs folyamatban: a korábbi „tudományos kínálati” innovációs modell hasznos eszköznek bizonyult a kormányzati pénzek kutatásba történő befektetéséhez. Az egyetem autonómiáját erősíti az, hogy csökken az állami finanszírozástól való függősége (Martin - Etzkowitz 2000). Azzal, hogy az egyetem vállalkozó lesz, kialakítja kapcsolatait a régióval, az iparral és az állami kormányzattal is. A következő indikátorok hasznosak az egyetem és az ipar közötti együttműködés eredményeinek értékelésében (Audretsch et al. 2002):

- az egyetemtől származó új technológiai ötleteken alapuló spin-off vállalkozások,

- az új technológiák licencének értékesítése,

- tudás-túlcsordulási hatások. 
A másik oldalról megközelítve, az egyetem együttmüködését a kormányzattal az egyetemi finanszírozás szerkezetének, az egyetem $\mathrm{K}+\mathrm{F}$ folyamatainak nyújtott kormányzati támogatásnak és az egyetem nagyobb kutatási projektekben történő részvételének segítségével lehet vizsgálni.

Néhány kutató nagyobb figyelmet fordít a vállalkozói egyetem „entrepreneurshipaspektusára”. Röpke (2000) szerint ez három dolgot jelenthet:

- A vállalkozói egyetem mint szervezet válik vállalkozóvá.

- Az egyetem tagjai valamilyen módon vállalkozókká válnak.

- A régióval kapcsolatosan az egyetem vállalkozói mintákat követ.

Tehát nagy kihívást jelent az vállalkozóvá válás támogatása az oktatási rendszerben az innovatív regionális fejlesztés elősegítése érdekében. Az elsődleges feladat az vállalkozói létforma köztudatban történő erősítése, valamint az oktatás, a képzés és a tanácsadás didaktikai, pedagógiai és fogalmi keretrendszerének átszervezése.

További kihívást jelent új pozíciók kialakítása az vállalkozástudománnyal foglalkozó professzorok és a kutatók számára, mivel azok a szereplők, akik ezen a területen szeretnének tevékenykedni, gyakran úgy érzik, hogy háttérbe vannak szorítva, illetve nincs összhang a többi érdekelttel. Sok vállalkozó, kockázati tőkés, tanácsadó és tudományos világban tevékenykedő szakember szerint a „vállalkozás tudománya” elsősorban gyakorlati alapokon nyugszik, és messze áll az elméleti hagyományoktól.

Ezért a fö cél a vállalkozásoktatás tudatos középpontba helyezése, valamint annak felismerése, hogy a vállalkozó válás támogatása elsősorban a „társadalmi változásról”, illetve a kultúrában végbemenő szükséges változásról szól, a jóléti színvonal fenntartásának és erösítésének érdekében.

A 9. ábra jól szemlélteti azt, hogy számos tényező befolyásolhatja, illetve ösztönözheti a vállalkozókészséget. Jelen értekezés keretein belül elsősorban a vállalkozásoktatásra koncentrálok, amely a számos meghatározó elemnek csupán egy részhalmaza. 
9. ábra: Az „entrepreneurship”-hez kapcsolódó kereslet-kínálat tényezők

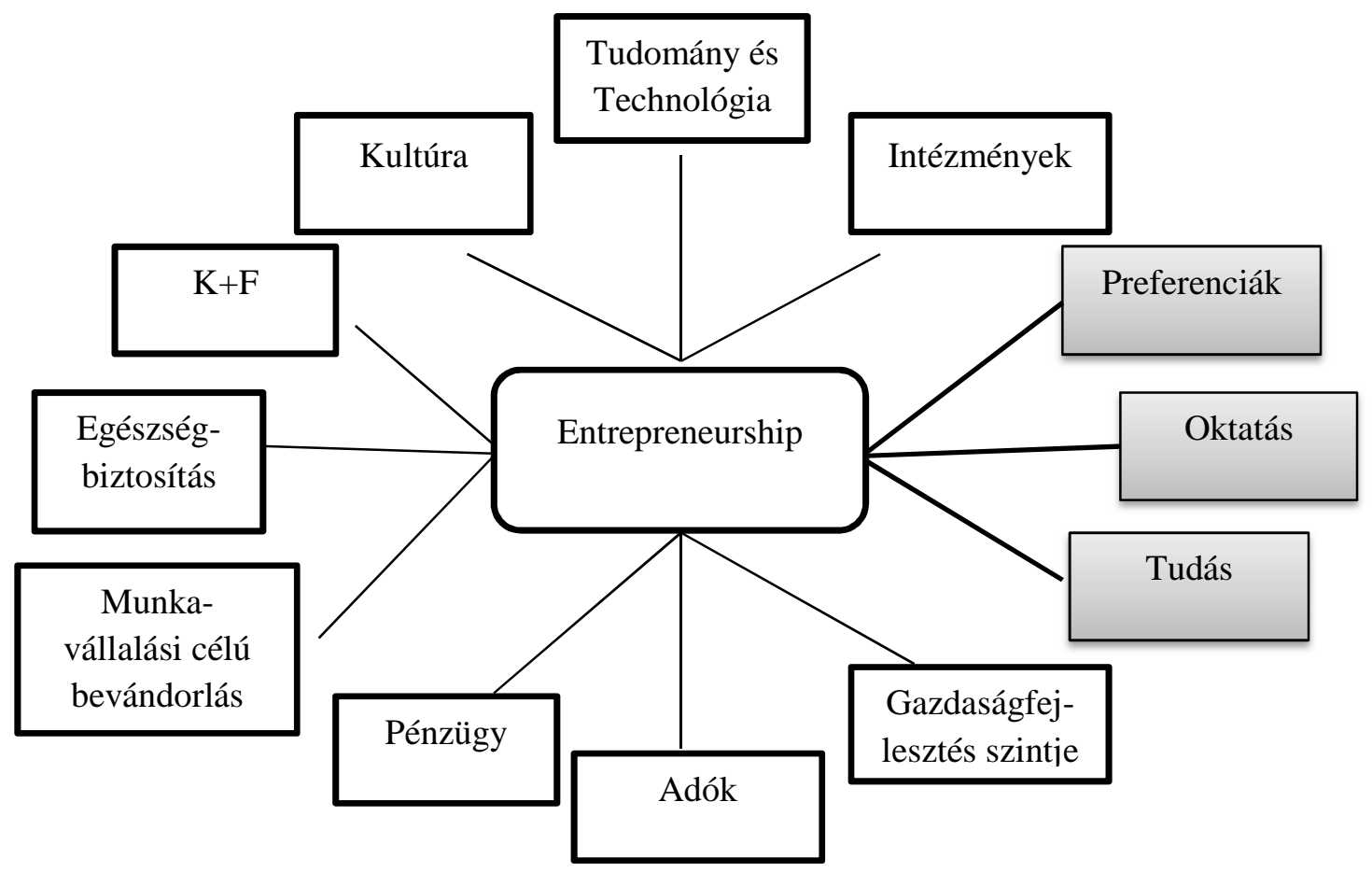

Forrás: Pena et al. (2010), 4. o. alapján saját szerkesztés

A jelenlegi gazdasági helyzetben az új vállalkozások indítása kulcsfontosságú tényező a gazdaság megújulásában és átszervezésében (Lourenco 2013), amit alátámaszt az is, hogy a tanulmány szerint az amerikai Fortune magazin 500-as listáján szereplő vállalatok több mint felét gazdasági hanyatlás idején alapították. Összességében a szakirodalom egyértelmüen rámutat arra, hogy a diplomások vállalkozói készségének ösztönzése rendkívül fontos (Gibb et al. 2009, Lourenco 2013).

A diplomások sikeres vállalkozóvá válásának pedig egyik legjobb eszköze pontosan a tudatosan müvelt vállalkozásoktatás a képzések minden szintjén, különösen a felsőoktatás keretein belül. Maga a vállalkozásoktatás egy meglehetősen „puha” fogalom, számos definíció létezik. Shepherd és Douglas (1997) szerint a vállalkozás lényege a képesség egy új üzleti vállalkozás pályájának elképzelésére és felvázolására a gyakorlati tudományokból és a külső környezetből származó információk kombinálásával a rendkívüli bizonytalanság kontextusában, mellyel egy új üzleti vállalkozásnak szembe kell néznie. Ez a kreatív stratégiákban, innovatív taktikákban, a trendek és piaci változások rejtelmeinek észlelésében, a nem egyértelmű előrehaladási irány esetén mutatott vezetésben, stb. nyilvánul meg. A vállalkozási kurzusoknak ezen képességek erősítését és fokozását kell szolgálnia. 
Hindle (2007) szerint a vállalkozásoktatás egyfajta tudástranszfer arra vonatkozóan, hogyan, ki és milyen hatásokkal fedezi fel, értékeli és aknázza ki a jövőbeni termékek és szolgáltatások létrehozásának lehetőségeit.

Fayolle (2009) szintén egy tágabb meghatározást javasol, miszerint a vállalkozásoktatás magába foglalja az összes olyan tevékenységet, amelynek célja: a vállalkozói gondolkodásmód, attitüdök, képességek elösegítése, valamint kiterjed az ötletgenerálás, startup, növekedés és innováció aspektusaira.

Mwasalwiba (2010) tanulmányában húsz cikket tekintett át annak érdekében, hogy meghatározza vállalkozásoktatás fogalmát. Az áttekintett tanulmányokból jól látszik, hogy nagyon kevés szerző kísérelte meg a vállalkozásoktatás közvetlen meghatározását. Azok, akik vállalkoztak rá, legtöbb esetben elakadtak az ellentétes vállalkozástudományi nézetek és a vállalkozás általános definíciójának jellemző hiánya miatt. Az vizsgált cikkek 32\%-a a vállalkozásoktatást összefüggésbe hozta valamilyen oktatási (vagy képzési) folyamattal, melynek célja az egyének hozzáállásának, viselkedésének, értékeinek, illetve szándékainak befolyásolása a vállalkozásalapítás irányába, mint lehetséges karrier, vagy annak közösségi szerepének elismerése érdekében (azaz vállalkozói társadalom létrehozása). A cikkek ugyancsak 32\%-a szerint szoros összefüggés van vállalkozásoktatás és a vállalkozói személyes készségek elsajátítása között. A vállalkozásoktatás definíciójában a maradék $36 \%$ a következőképpen oszlik meg: új vállalkozás alapítása (18\%), lehetőségek felismerése (9\%), valamint meglévő kisvállalatok irányítása (9\%).

McMullan (1987) szerint a vállalkozásoktatás egy igen speciális terület, amely négy főbb ponton különbözik a felsőoktatás más formáitól. Először is az eredmények nem csupán hosszútávon jelennek meg, hanem már rövidtávon is jelentkeznek kézzelfogható outputok. Másodszor az eredmények valósak, a hallgatók, illetve végzett hallgatók folyamatosan hoznak létre újabb és újabb vállalkozásokat. Harmadszor a növekvő új vállalkozások jövő vezetőit hozzák létre. Végül, újabb tudás jön létre, amelyből minden közösségi résztvevő profitál (McMullan 1987). Továbbá a különbségek vizsgálatánál ki kell emelni, hogy az egyetemi programokkal ellentétben a vállalkozásoktatási programok teljesítménye nem mérhető a végzett hallgatók számával. A programok sikeressége az általuk létrejött társadalmi-gazdasági hatásokkal mérhetőek. azaz mennyi vállalkozás/munkahely jött létre? Milyen növekedési ütemet produkálnak? Nemzetköziesednek? Hozzájárulnak a lokális gazdaságfejlődéshez? 
Fayolle (2007) azt vizsgálja, hogy vállalkozásoktatásból milyen előnyök származnak, ezeket a következő három csoportra osztotta:

- Hozzájárulás a személyes fejlődéshez. A vállalkozás lehetővé teszi az egyének számára tehetségük és kreativitásuk fejlesztését, álmaik megvalósítását, nagyobb függetlenség elérését, és egyfajta szabadságérzetet.

- Az országok vállalkozói kultúrájának fejlesztése. A vállalkozás társadalmi és gazdasági dimenziókhoz kapcsolódik. A vállalkozás nem csak az egyéni fejlődés része, hanem a piacgazdaságban a gazdasági növekedés motorja is. Ezért a vállalkozásoktatás kulcsfontosságú eszköz egy ország vállalkozói kultúrájának fejlesztésében.

- Az új vállalkozások túlélési és sikerességi esélyeinek növelése. A vállalkozásoktatás eszköznek tekinthető az újonnan létrehozott vállalatok túlélési és sikerességi rátájának növelésében.

A fenti felsorolást Pena és szerzőtársai (2010) kibővítették és a vállalkozásoktatásból származó potenciális előnyöket az alábbi csoportokra bontották szét:

- Növekvő vállalkozói tevékenység. Azzal, hogy a fiatalok és a felnőttek számára egyfajta karrierlehetőségként jelenik meg a entrepreneurship, a vállalkozásoktatás nem csak a potenciális vállalkozók körét bővítheti, hanem nagyobb érdeklődést és támogatást is eredményezhetnek azok számára, akik új vállalatokat kívánnak indítani és fejleszteni.

- A vállalkozások nagyobb változatossága. A vállalkozásoktatás többféle csoport számára teszi lehetővé a készségek elsajátítását és hálózatok kialakítását a vállalkozói tevékenység eredményességének érdekében. A potenciális vállalkozók körében lévő sokféleség az ötletek és perspektívák sokrétűbb forrásait jelenti a lehetőségek felismerésében és a megoldások fejlesztésben.

- Több vállalkozói siker. Abban az esetben, ha a vállalkozástudományt hatékonyan tanítják, több és jobb vállalkozót eredményezhet és növelheti a vállalati sikerességi arányokat.

- Nagyobb motiváció a veszélyeztetett csoportok számára, hogy befejezzék formális tanulmányaikat. Néhány esetben a vállalkozásoktatási programok különösen vonzónak lehetnek a veszélyeztetett fiatalok számára és segíthetnek megfékezni az iskolai kimaradásokat. 
- Nagyobb arányú üzleti érzékkel rendelkező népesség. A vállalkozásoktatás élethosszig tartó tanulást és 21. századi készségeket, valamint az üzleti menedzsment kompetenciák gyakorlati alkalmazását tanítja. Minél elérhetőbbek a programok, annál több lehetőség nyílik a fiatalok és felnőttek számára a kompetenciák elsajátítására és az eredményesebb élet elérésére.

- A kreatív és kritikai gondolkodás fejlesztése. A vállalkozásoktatás nagy hangsúlyt helyez a tanulók kognitív képességeinek fejlesztésére a kreativitás, a lehetőség felismerés és a kritikai gondolkodás területein. Azok a hallgatók, akik vállalkozástudományi programokban vesznek részt, magasabb szintű kreativitással és kritikai gondolkodási képességekkel rendelkezhetnek.

Különböző megközelítések léteznek a vállalkozásoktatás egyetemi szinten történő integrálására. Streeter és szerzőtársai (2002) két fő szemléletet különböztet meg: a fókuszált és az egyesített megközelítés (azaz egyetemre kiterjedő megközelítés). A fókuszált megközelítés lényege, hogy a kar, a hallgatók és az oktatók kizárólag az üzleti tudományos területhez kapcsolódhatnak. Erre egy jó példa Harvard Business School, melynek vállalkozástudományi programjai kizárólag az iskola hallgatóit célozza meg. Más karok hallgatói is jelentkezhetnek, azonban csak meglehetősen korlátozott számban kerülnek be a programba. Ezzel szemben az egyesített megközelítés fókusza tágabb, az üzleti iskolán kívül eső területek hallgatóit is célozza. Az utóbbi években az egyetem minden karára kiterjedő vállalkozásoktatás felé mutató trend egyre erőteljesebb az Egyesült Államokban és Európában is, így e megközelítésnek napjainkban nagyobb a relevanciája. Az egyesített megközelítésnek két változat különböztethető meg: a mágnes modell és a sugár modell. A mágnes modell esetén a hallgatók az egyetem egész területéről érkeznek, azonban a vállalkozói tevékenységeket egyetlen tudományos egység kínálja. Ez azt is jelenti, hogy minden forrás és készség egyetlen „platformban” egyesül, amely elősegíti a vállalkozói tevékenységek koordinálását és megtervezését. Ezt a megközelítést alkalmazza a MIT, ahol a vállalkozásoktatási programokat a Sloan School of Management irányítja.

A sugár modellben az egyes intézmények és karok felelősek a vállalkozástudományi tevékenységek integrációjának és elérhetőségének elősegítéséért, így ebben az esetben a vállalkozási tevékenységeket az egyes karok speciális felépítéséhez lehet igazítani. Ezt a modellt alkalmazza például a Cornell University, ahol a vállalkozásoktatás kilenc iskolában és föiskolán valósul meg. 
Mitra és Manimala (2008) szerint az oktatásnak két fő szerepe van az „entrepreneurship”, sikeres vállalkozás támogatásában. Egyrészt általános és középiskolai szinten az oktatók kialakíthatják, erősíthetik a vállalkozói attitüdöt a diákokban, amelynek következtében később nagyobb eséllyel fognak bele vállalkozásalapításba. Másrészről, a már meglévő vállalkozói szemléletmódra építve, a felsőoktatásban megszerzett további vállalkozói, menedzseri ismeretek és készségek által tovább erősítik, fejlesztik a hallgatók vállalkozói vénáját (10. ábra).

10. ábra: Vállalkozásalapításra ható oktatási tényezők

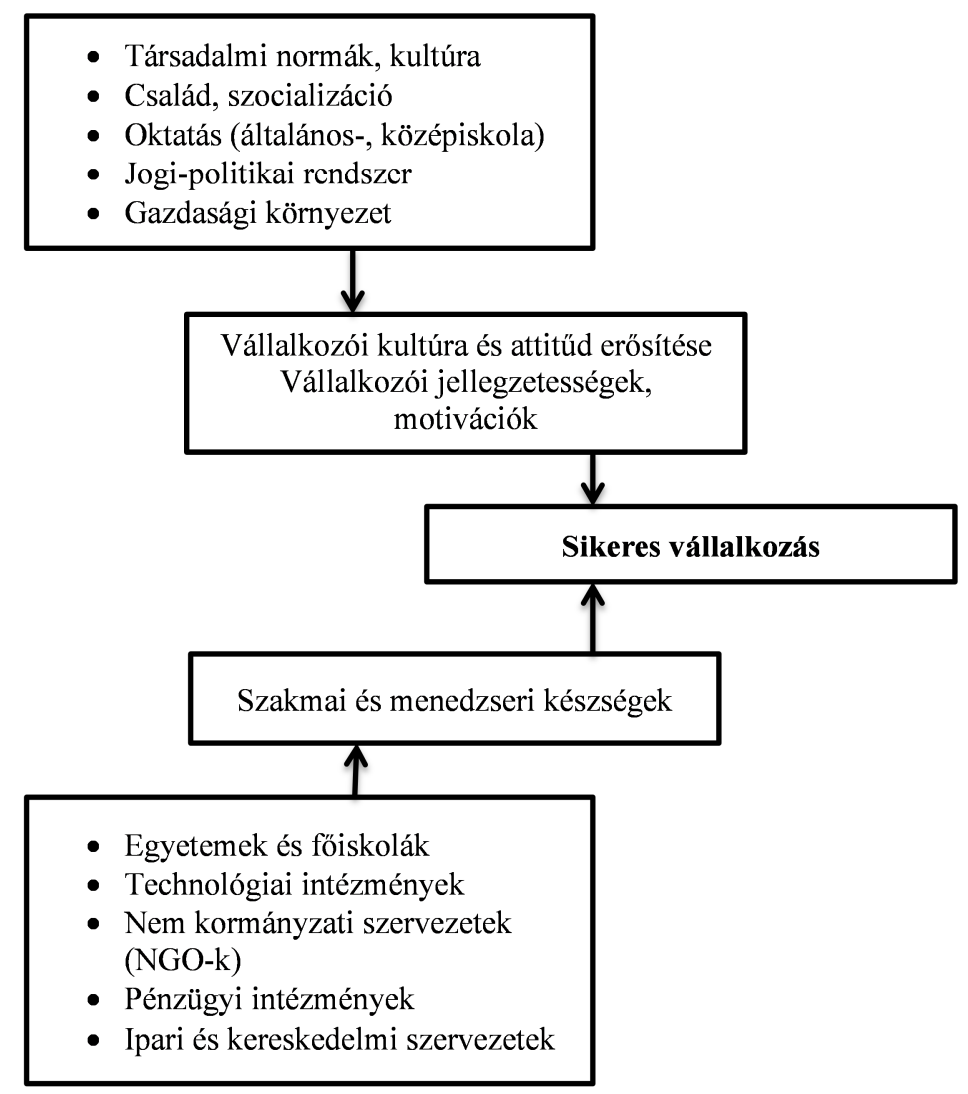

Forrás: Mitra-Manimala (2008), 51. o.alapján saját szerkesztés

Véleményem szerint az ábra rendkívül jól összefoglalja, hogy a sikeres vállalkozóvá váláshoz számos tényező szükséges, emellett a felsőoktatásban megvalósuló vállalkozásoktatás sikeressége nagymértékben függ attól, hogy milyen „,nyersanyag” érkezik a középoktatásból. Éppen ezért a felsőoktatás egyik fontos szerepe lehet az általános- és középiskolában tanítók felkészítése annak érdekében, hogy vállalkozói attitüd minél hamarabb kialakuljon az egyénekben. 


\subsection{Vállalkozásoktatás céljainak és célcsoportjainak meghatározása}

Az alapvető definíciók szintézise után kísérletet teszek a vállalkozásoktatás lehetséges céljainak és célcsoportjainak bemutatására. A vállalkozásoktatás egyik fő célja, amely megkülönbözteti a tipikus üzleti oktatástól, a kihívás, hogy minél gyorsabban, különböző ötletek szélesebb választéka szülessen meg az üzleti lehetőség kiaknázására, valamint a képesség egy alaposabb cselekvéssor kigondolására a vállalkozásindítás érdekében (Vesper és McMullan, 1988). A vállalkozásindítás alapvetően eltérő tevékenység a vállalkozás menedzselésétől (Gartner és Vesper, 1994), a vállalkozói oktatásnak foglalkoznia kell a vállalkozásindítás bizonytalan jellegével (Gartner et al., 1992). Ennek érdekében a vállalkozói oktatásnak készségfejlesztő kurzusokat kell tartalmaznia a tárgyalás, vezetés, új termék fejlesztése, kreatív gondolkodás és technológiai innováció területein (Solomon 2007).

Általában véve, a vállalkozásoktatás célja a vállalkozástudomány mint karrierlehetőség iránti tájékozottság növelése, és egy üzleti vállalkozás elindítási és irányítási folyamatának minél teljesebb megértése (Donckels 1991). Interman szerint szerint a vállalkozástudományi programoknak négy célja van (Lee-Wong 2007):

1. vállalkozástudományi tájékozottság növelése,

2. vállalkozás létrehozása,

3. kisvállalkozások fejlesztése, valamint

4. oktatók képzése.

Hasonlóan, Jamesion szerint a vállalkozásoktatás három különböző képzés típust biztosít (Lee-Wong 2007):

1. oktatás a vállalkozásról (azaz vállalkozástudományi tájékozottság),

2. oktatás a vállalkozásért (azaz a vállalkozók felkészítése a vállalkozás létrehozására) és

3. oktatás a vállalkozásban (azaz a vállalkozók felkészítése a megalapított vállalkozás növelésére és fejlesztésére).

Mwasalwiba (2010) húsz, vállalkozásoktatásról szóló tanulmány vizsgálata során arra a következtetésre jutott, hogy a vállalkozásoktatás célja:

1. a vállalkozói beállítottság, szellem és kultúra kialakítása vagy növelése az egyének körében,

2. új vállalkozás létrehozása és munkahelyteremtés, 
3. a helyi vállalkozások alapításának és növekedésének segítésén keresztuil a helyi közösség támogatása; valamint

4. a vállalkozói készségek ösztönzése.

Ezzel szemben Johanisson állítása szerint a vállalkozásoktatás öt céllal rendelkezik, amelyben a vállalkozástudományi programok résztvevői kialakítják (Lee-Wong 2007)

1. a miért ismeretét (az elindításhoz való megfelelő hozzáállás és motiváció kialakítása);

2. a hogyan ismeretét (a vállalkozás fejlesztéséhez szükséges technikai készségek és képességek elsajátítása);

3. a ki ismeretét (a vállalkozások kapcsolatának és hálózatának elősegítése);

4. a mikor ismeretét (az éles intuíció elérése, amellyel a megfelelő pillanatban tudnak cselekedni); és

5. a mi ismeretét (a tudásbázis és információk elérése az új vállalkozás fejlesztéséért).

\section{Tágabb értelmezésben, a vállalkozásoktatás négy fö célja a következő (Sexton-Kasarda} 1992 - idézi Lee-Wong 2007):

1. felkészíteni a résztvevőket a pályafutási sikerre

2. a jövőbeli tanulás képességének növelése

3. megvalósítani a résztvevők személyes beteljesülését

4. hozzájárulni a társadalomhoz.

Alberti (2004) szerint a vállalkozásoktatás céljai:

1. a vállalkozói tudás megszerzése

2. a megfelelő módszerek alkalmazásának megszerzése az üzleti szituációk elemzése, valamint akciótervek szintézise során

A tanulmányok által leggyakrabban említett vállalkozásoktatási célok (Alberti et al. 2004):

- a vállalkozásra vonatkozó ismeretek elsajátítása,

- a módszerek alkalmazásához, az üzleti helyzetek elemzéséhez és a cselekvési tervek összefoglalásához szükséges készségek elsajátítása,

- a vállalkozói ösztön, tehetség és készség felismerése és ösztönzése,

- számos elemzési módszer kockázatkerülő beállítottságának megszüntetése,

- empátia és támogatás kialakítása a vállalkozás sajátos jellemzői felé, 
- a hozzáállás átalakítása a változás felé,

- új start-up és egyéb vállalkozó vállalatok elősegítése, valamint

• az „érzelmi szocializációs összetevő” ösztönzése.

Fayolle (2007) szerint a vállalkozásoktatási célokat három kategóriába lehet sorolni:

- tudatosság növelése,

- oktatási módszerek, eszközök és helyzetkezelés, valamint

- projekttulajdonosok támogatása.

A tudatosság növelése esetében a cél az, hogy a hallgatók megismerkedjenek a lehetőségeikkel, karriert lássanak az új vállalkozás alapításában. Az oktatási módszerek, eszközök, helyzetkezelési módok esetében a cél a tudás, a sajátos technikák és készségek transzfere és fejlesztése köré épülnek a hallgatók vállalkozói potenciáljának növelése érdekében. Végül, a projekttulajdonosok támogatásánál a cél olyan hallgatókkal vagy résztvevőkkel történő munka, akik ténylegesen részt vesznek vállalkozásalapítási projektekben.

A lehetséges célok megismerése után nagyon fontos kiemelni két ismétlődő jelleggel megjelenő tényezőt.

Egyrészt a legtöbb felmérés azt mutatja, hogy a vállalkozásoktatás egyértelműen eredményesen ösztönzi a hallgatókat a saját vállalkozás elindítására. Egy graduális vállalkozási program áttekintése szerint az Egyesült Királyságban a program a résztvevők több mint felét ösztönözte abban, hogy vállalkozásukat hamarabb kezdjék el, mint azt tervezték (Brown 1990). Végül, Vesper és McMullan (1997) kimutatták, hogy azok a hallgatók, akik teljesítették a start-up cég létrehozását is előíró kurzusokat, sokkal jobb döntéseket képesek hozni. Persze ebben az is szerepet játszhat, hogy már eredetileg is más képességü és motiváltságú hallgatókból kerülnek ki a start-up kurzust elvégzők.

Másrészt legalább ilyen fontos megállapítás és alapvetően determinálja a képzések sikerességét az igények pontos feltérképezése. McMullan és Long (1985) szerint a vállalkozásoktatást, így a vállalkozástudományi kurzusokat is a vállalkozás fejlődésének szakaszai szerint kell megkülönböztetni, mintsem a gyakorlati szakértelem szerint. Az egyes célcsoportok igényei eltérhetnek attól függően,, hogy a fejlődés mely szakaszában vannak, így például más kurzusokra van szükség a tájékozódás során, az indulás előtti 
időszakban, valamint érett vállalkozások esetén. Gibb (2002) szerint a vállalkozóknak több kell a vállalkozásindítási ismereteknél, a menedzsment készségeknél és az alapszintü üzleti ismereteknél. A vállalkozóknak elsősorban vállalkozási készségekre van szükségük a vállalataik támogatásához és a gyorsan változó üzleti környezet kezeléséhez.

A fentiekkel szoros összhangban amennyiben vállalkozásoktatást a vállalkozás kialakításának egyes szakaszaiban szükséges különböző készségek alapján kívánjuk felépíteni, akkor az üzleti életbe (vállalkozástudomány) történő lépés megértéséhez szükséges készségek és tudás eltér a folyamatban lévő üzlet müködtetésének (üzleti menedzsment) megértéséhez szükséges készségektől és tudástól. Következésképp sajátos - sőt gyakran a célcsoportra specializált tantervekre és képzési programokra van szükség a vállalkozásoktatáshoz. Zeithaml és Rice (1987) megjegyzi, hogy bár a vállalkozástudományi oktatás és a kisvállalkozási menedzsmentoktatás nem ugyanaz, a két kifejezés olyan szoros összefüggésben áll, hogy szinte lehetetlen az egyik a másik figyelembevétele nélkül. A vállalkozástudományi kurzusok a vállalkozás elindításának kérdéses elemeit hangsúlyozzák, mint pl. az új szervezetek, új termékek és új piacok kialakítását, míg az üzleti menedzsment kurzusok az üzleti eljárásokhoz szükséges tudásra és készségekre helyezik a hangsúlyt. Emellett Dreisler (2007) rávilágít arra, hogy az egyetemi oktatóknak törekedniük kellene a hallgatók motiválására. Ehhez azonban számos változás szükséges a pedagógiára, illetve az intézmények általános oktatási környezetére nézve.

A vállalkozásoktatási programok kidolgozása során figyelembe kell venni, hogy a különböző típusú programok különböző csoportokat vonzanak. A vállalkozásoktatás nem minden résztvevője szeretne új vállalkozást indítani, néhányan egyszerüen azért vesznek részt egy programon, hogy bővítsék ismereteiket egy bizonyos területen. A vállalkozástudomány oktatói számára az a kihívás, hogy kurzusaikkal és programjaikkal az összes érdekelt felet megcélozzák. Továbbá a vállalkozók gyakran vonakodnak részt venni a helyi főiskolák és egyetemek által kínált kurzusokon, mert úgy vették észre, hogy ezek a kurzusok túlságosan elméleti jellegüek és „tudományos szempontból orientáltak” (McCarthy et al. 1997). A célcsoportok kialakítása során mindenképpen figyelembe kell venni, hogy az egyetemek tudásmonopóliuma megszünőben, hiszen az információs forradalom következtében az ismeretek szinte korlátlanul elérhetőek. Emellett ahogy Barakonyi $(2004,3$. o.) fogalmaz , $a z$ egyszeri intenzív tanulási folyamatot felváltja az életen át tartó tanulás igénye”, azaz már 
nem csupán a „hagyományos” 18-24 éves korosztályra kell koncentrálni, hanem „a társadalom szinte minden rétege merítési közeggé válik."

Következésképpen a vállalkozásoktatási programok változatos célközönsége között eltérő szociodemográfiai háttérrel, illetve a vállalkozói folyamatban eltérő részvételi és törekvési szinttel rendelkező hallgatókat találunk. Jelentős különbségek vannak a például diplomás menedzsment hallgatók és a tudományos, müszaki vagy irodalmi háttérrel rendelkező hallgatók, illetve az oktatók és PhD hallgatók részére szánt kurzusok között. Hasonlóképpen, a vállalkozásoktatás egész más jelleget ölt az erős vállalkozásalapítási szándékkal, vagy projektötlettel rendelkezők és a sem szándékkal, sem konkrét projekttel nem rendelkező hallgatók esetében.

Habár néhány esetben túlzott hangsúlyt kap, a pedagógia önmagában nem egy cél. A pedagógia egy eszköz a célok eléréséhez. Amint a konkrét célok megfogalmazódnak és a korlátok beazonosításra kerülnek, ki lehet választani a megfelelő oktatási módszereket (Fayolle et al. 2008). Másrészt viszont a vállalkozásoktatási program hatékonysága nagyrészt az oktató készségén és tudásán múlik a különböző oktatási módszerek, különösképpen a vállalkozásoktatási módszerek területén.

A vállalkozásoktatási és képzési kurzusok iránti növekvő kereslete Fayolle (2007) szerint három forrásra vezethető vissza.

- kormányzati forrás,

- hallgatók,

- kis-, közép- és nagyvállalatok.

A kormányzati forrás abból indul ki, hogy a gazdasági növekedés, a munkahelyteremtés, a gazdasági szerkezet megújítása, technológiai és politikai változás és innováció nagyrészt a vállalat és tevékenység létrehozóitól függ. Ezért egyre nagyobb érdeklődést mutat a vállalkozók iránt, emellett előtérbe kerülnek a vállalkozóvá válást, valamint a jövő vállalkozóinak oktatására vonatkozó kérdéskörök.

A hallgatók képviselik a kereslet második forrását. A hallgató egy része szeretne saját vállalatot alapítani, míg mások szeretnének olyan szaktudást elsajátítani, mely nélkülözhetetlen egy (kis-, közép vagy nagy) vállalatnál történő elhelyezkedésük, valamint karrierjük során. A vállalatok valóban egyre nagyobb érdeklődést mutatnak a 
vállalkozástudomány iránt és egyre inkább a vállalkozói tevékenységben hasznos tudással, és olykor tapasztalattal, rendelkező egyének közül toborozzák fiatal vezetőiket.

Következésképpen a kis-, közép-, illetve nagyvállalatok alkotják a harmadik fő forrást. Vezetőik manapság más vezetői készségeket és viselkedési módokat preferálnak, mint a korábbi években.

Mwasalwiba (2010) szerint az alábbi legfontosabb célcsoportok jelennek meg a vállalkozásoktatással foglalkozó tanulmányokban (a sorrend az egyes csoportok fontossági sorrendjét követi):

1. az egyetemi üzleti hallgatók,

2. a meglévő kisvállalkozások tulajdonosai, vezetői és alkalmazottai,

3. hátrányos helyzetủ csoportok (nők, etnikai csoportok, fogyatékossággal élők),

4. non-business hallgatók,

5. munkanélküliek,

6. a döntéshozók, bankárok, adóhatóságok és nagyközönség alkotják.

Továbbá a szerzők megvizsgálták, hogy melyek a vállalkozásprogramokban oktatott legáltalánosabb tárgyak:

1. erőforrás mozgósítás és finanszírozás (16\%);

2. marketing és értékesítés (14\%);

3. ötlet fejlesztés és lehetőségek felfedezése (13\%);

4. üzleti tervezés (12\%);

5. növekedés kezelése (12\%);

6. szervezet és csapat építés (10\%);

7. új vállalkozás létrehozása (9\%);

8. SME menedzsment (8\%); valamint

9. kockázat és ésszerüség (6\%).

A továbbiakban megemlítenénk két „speciális” célcsoportot. Egyrészt Brush (1992) és Krueger (1993) szerint a vállalkozásoktatásnak olyan hallgatókat is meg kellene célozna, akik családjában (közvetlen környezetében) van vállalkozó, hiszen ők sokkal fogékonyabbak az ilyen jellegü oktatásra, mivel a vállalkozói szemléletmód gyerekkoruk óta formálódik. Másrészröl egyre többször megjelenik a középiskolai vállalkozásoktatás szükségessége. Chamard (1989) - az Egyesült Királyságban végzett kutatásai során - azt tapasztalta, hogy az 
akkori középiskolai rendszer akadályozza a vállalkozástudományt és nem járul hozzá a vállalkozói szemléletmód kialakulásához. Éppen ezért az utóbbi időben számos kezdeményezés jött létre a vállalkozói kultúra fiatalok körében történő elősegítése érdekében (Junior Achievement Young Enterprise, Primary Enterprise Programme, Dynamo Programme stb.).

Az eddigiekből úgy tünik, hogy a legtöbb szerző két csoportra osztja az oktatási módszereket, név szerint „hagyományos módszerek” (a hagyományos előadások alkotják) és „,innovatív módszerek” (cselekvés alapúak), más néven „passzív módszerek” és „aktív módszerek". A vállalkozásoktatás célcsoportjai eltérőek lehetnek attól függően, hogy mely tényezők mentén vizsgálódunk.

Amennyiben a „tudományos hátterük” alapján vizsgáljuk beszélhetünk:

- hallgatókról (nappali, esti, alapszak, mesterszak, üzleti-nem üzleti képzésben résztvevők),

- kutatókról,

- potenciális vállalkozókról,

- vállalkozókról.

4. táblázat: Potenciális célcsoportok

\begin{tabular}{|l|l|l|l|l|}
\hline & \multicolumn{1}{|c|}{$\begin{array}{c}\text { Üzleti } \\
\text { Tudományok }\end{array}$} & \multicolumn{2}{c|}{ Nem Üzleti Tudományok } \\
\hline & & & \multicolumn{1}{c|}{ High-tech } & Humán \\
\hline \multirow{5}{*}{ Hallgató } & Alapszak & $\mathrm{X}$ & $\mathrm{X}$ & $\mathrm{X}$ \\
\cline { 2 - 5 } & Mesterszak & $\mathrm{X}$ & $\mathrm{X}$ & $\mathrm{X}$ \\
\cline { 2 - 5 } & $\begin{array}{l}\text { Egyéb (MBA } \\
\text { stb.) }\end{array}$ & $\mathrm{X}$ & $\mathrm{X}$ & $\mathrm{X}$ \\
\hline Kutató & $\mathrm{X}$ & $\mathrm{X}$ & $\mathrm{X}$ \\
\hline Potenciális vállalkozó & $\mathrm{X}$ & $\mathrm{X}$ & $\mathrm{X}$ \\
\hline Vállalkozó & $\mathrm{X}$ & $\mathrm{X}$ & $\mathrm{X}$ \\
\hline
\end{tabular}

Forrás: Saját szerkesztés

A vállalkozásalapítás egyik alapfeltétele az ötlet. Éppen ezért az alábbiak szerint is csoportosíthatunk:

- résztvevők, akik nem rendelkeznek ötlettel a vállalkozásindításhoz,

- résztvevők, akik konkrét ötlettel rendelkeznek vállalkozásindításhoz,

- résztvevők, akik csak egy alap és bizonytalan ötlettel rendelkeznek a vállalkozásindításhoz. 
A vállalkozásoktatást bele kellene foglalni a mérnöki tudomány és a természettudomány ágakba, ahol termékötletek ténylegesen felmerülnek, azonban a hallgatók nem rendelkeznek az induláshoz szükséges megfelelő ismeretekkel és készségekkel. Ennek fényében, növekvő trend mutatkozik az egész egyetemre kiterjedő vállalkozásoktatási programok felé. Streeter és szerzőtársai (2002) szerint az egész egyetemre kiterjedő programok fő célja a vállalkozásoktatás lehetőségének kiterjesztése az egyetem összes hallgatójára, függetlenül attól, hogy az adott hallgató mely karra, illetve szakra jár.

\subsection{Vállalkozásoktatás és vállalati oktatás közötti eltérések}

Számtalan „entrepreneurship”-programmal, illetve kurzussal találkozhatunk a fejlett országokban, azonban a programok fejlődésének ellenére még mindig nincs egy általánosan elfogadott tanterv, keretrendszer. Számos program többszöri próbálgatás után alakul ki a kurzusra jelentkező hallgatók visszajelzéseitől függően. A vállalkozói programok sokszínűsége megjelenik a vállalkozásoktatásban és képzésben használt módszerek, módszertanok sokféleségében is. Shepherd és Douglas (1997) szerint a vállalkozásoktatási megközelítések alapvetően négy kategóriába sorolhatóak:

- a „régi háborús történetek” megközelítés,

- az „esettanulmány” megközelítés,

- a „tervezés” megközelítés és

- az „általános cselekvés” megközelítés.

A „régi háborús történetek” megközelítés sikeres vállalkozási történetekkel próbálja motiválni a vállalkozókat, miközben feltárja, hogyan lettek azok az egyének sikeres vállalkozók. Az „esettanulmány” megközelítés létező vállalkozások eseteit használja, hogy elemezze a vállalkozási folyamatot. Eközben a hallgatók különböző megoldásokat dolgoznak ki a cégek problémáira. A „tervezés” megközelítés általában egy üzleti terv kidolgozását jelenti, míg az „általános cselekvés” megközelítés az optimális vállalkozói cselekvések kidolgozására helyezi a hangsúlyt a létező piaci erők alapján.

A szakirodalomban gyakran összekeveredik a „vállalati” (enterprise) és a „vállalkozás” (entrepreneurship) oktatás fogalma. Valójában a két kifejezést gyakran egymás szinonimájaként használják, mindemellett állandó viták vannak a terminológiáról, a 
definícióról és a használatról. Jones és Iredale (2010) szétválasztja a két fogalmat és azt mondja, hogy a vállalkozásoktatás elsődlegesen a következőkre fókuszál:

- hogyan kell elindítani egy vállalkozást, beleértve a vállalkozás indításának kulcsfolyamatait;

- hogyan kell megtervezni és elindítani egy új üzleti vállalkozást;

- hogyan kell egy vállalkozást növelni és irányítani;

- a vállalkozás müködtetéséhez szükséges készségek és viselkedésmódok fejlesztése;

- a vállalkozói készségek és ismeretek alkalmazása üzleti környezetben;

- a vállalkozás elindításához szükséges tudás és készségek közvetlen használata; valamint

- magánvállalkozás.

Ezzel szemben a „vállalati-oktatás” elsődlegesen a következőkre helyezi a hangsúlyt:

- aktív tanulásra épülő vállalati oktatási pedagógia;

- állampolgárként, fogyasztóként, alkalmazottként, illetve magánvállalkozóként történő hatékony szerepvállaláshoz szükséges tudás a rugalmas piacgazdagságban;

- személyes készségek, viselkedésmódok és tulajdonságok fejlesztése különböző környezetekben történő alkalmazáshoz;

- a személy mint vállalkozó egyén - a közösségben, otthon, a munkahelyen, illetve vállalkozóként;

- a vállalkozói készségek, viselkedésmódok és tulajdonságok alkalmazása az életpálya minden szakaszában; valamint

- hogyan müködik egy vállalkozás, különösképpen egy kisvállalkozás.

A vállalkozásoktatás elsősorban a vállalkozó igényeire fókuszál, míg a vállalati oktatás a stakeholderek szélesebb körének igényeivel foglalkozik, mint például a fogyasztók és a közösség. Mindazonáltal a két kifejezés közötti fö különbség az, hogy a vállalkozásoktatás elsődlegesen a vállalkozás elindítására, növelésére és irányítására összpontosít, míg a vállalati oktatás elsősorban azon személyes készségek, képességek és tulajdonságok elsajátítását helyezi a középpontba, melyek a különböző környezetekben, az életpálya minden szakaszában alkalmazhatóak. A UK National Council for Graduate Entrepreneurship (NCGE) ezt a nézetet erősíti meg: a vállalati koncepció a „vállalkozó személy és vállalkozói 
gondolkodásmód" fejlesztésére helyezi a hangsúlyt. Az előbbi személyes készségekből, tulajdonságokból, viselkedési és motivációs képességekből áll, melyek bármely környezetben alkalmazhatóak (társadalmi, munkahelyi, szabadidős, stb.) Az NCGE így folytatja: a vállalkozói koncepció a vállalkozói készségek új vállalkozás alapításának, meglévő vállalkozás fejlesztésének/növelésének, valamint vállalkozói szervezet tervezésének (melyben a vállalkozói készségek hatékony alkalmazásának képességét ösztönzik) kontextusában történő alkalmazására koncentrál (Crayford 2013). Hasonlóan Draycott és szerzőtársai (2011) szerint a vállalati oktatást gyakran összekeverik a vállalkozói tanulással. A vállalati oktatás célja az egyéni tudatosság, készségek és potenciál fejlesztése, miközben igyekszik tanulóközpontú lenni és új pedagógiai módszereket, technológiákat alkalmazni. Emellett megemlíthető kritikaként, hogy túl nagy figyelmet kap az intézményi ellenőrzés, a rend szükségessége, valamint az elöírt és mérhető tanulási eredmények. Ezzel szemben a vállalkozói tanulást inkább a kreativitás, informalitás, kíváncsiság, érzelem, valamint a személyes és valódi problémák, illetve lehetőségek alkalmazása vezérli, csakúgy mint innováció és új vállalkozás létrehozása.

A vállalkozás és vállalkozói oktatás közötti egyik fő különbség az alkalmazott pedagógiai módszerben rejlik. A vállalkozásoktatás például hagyományos, didaktikus módszereket alkalmazhat (Jones - Iredale 2006) az üzleti ötletek létrehozásának, üzleti tervezésnek és az új vállalkozás alapításának tanításában és elsajátításában. Ezzel ellentétben a vállalati oktatás kreatívabb, innovatívabb pedagógiai megközelítést alkalmaz, amely kihasználja a gyakorlati tanulási módszereket. A vállalati oktatás területe és gyakorlata sokkal szélesebb körü, mint a vállalkozásoktatásé, amely túlságosan is a vállalkozás elindítására koncentrál.

Draycott et al. (2011) szerint a vállalkozói tanulás (entrepreneurial learning) a vállalati oktatás struktúrájának és kontextusának része, a merevebb és hagyományosabb vállalkozásoktatási megközelítéssel szemben. Crayford (2013) a „vállalkozói oktatást” (entrepreneurial education) hatékony áthidalásnak tekinti a vállalati és vállalkozásoktatás között, összekötve a vállalati filozófiát az innovatívabb gyakorlatokkal és a vállalkozói tanulás középpontba helyezésével. A vállalati oktatás tanulási filozófiája, az innovatív pedagógia, a reflekció és a tapasztalati tanulás számos egyéni készség kialakulását eredményezi. A vállalkozói oktatással kapcsolatban felmerülő elképzelések sokrétűbbek, mint pusztán a hallgatók megtanítása új üzleti tervek készítésére, illetve start-upok létrehozására, valamint irányítására (hagyományos vállalkozásoktatás). 
A UK National Council for Graduate Entrepreneurship szerint a vállalkozói oktatásnak ténylegesen ,vállalati fogalom és a vállalkozó személy vállalkozói gondolkodásmód általi kifejlődése" megtestesülésének kell lennie, a (Jones - Iredale, 2010). Gibb (2008) egy tágabban értelmezhető meghatározást javasolt, miszerint „egyénileg és/vagy kollektívan alkalmazott viselkedési módok, készségek és tulajdonságok, melyek elösegítik az egyéneket és szervezeteket a magasabb fokú bizonytalansággal és komplexitással járó változások és innovációk kialakításában, kezelésében és élvezésében, melyek eszközként szolgálnak a személyes kiteljesedés és a szervezeti hatékonyság eléréséhez."

A vállalkozásoktatás fogalma alatt a továbbiakban a fenti fogalmak egyfajta kombinációját, közös metszetét értem (11. ábra). A szakirodalomban nincs egységes álláspont arra vonatkozóan, hogy mi is az a vállalkozásoktatás, illetve maga a fogalomhasználat sem letisztult. Éppen ezért nem egy konkrét definíciót választok ki, hanem véleményem szerint a vállalkozásoktatás magába foglalja mindhárom fogalomrendszert.

11. ábra: Vállalkozásoktatás - vállalkozói oktatás - vállalati oktatás

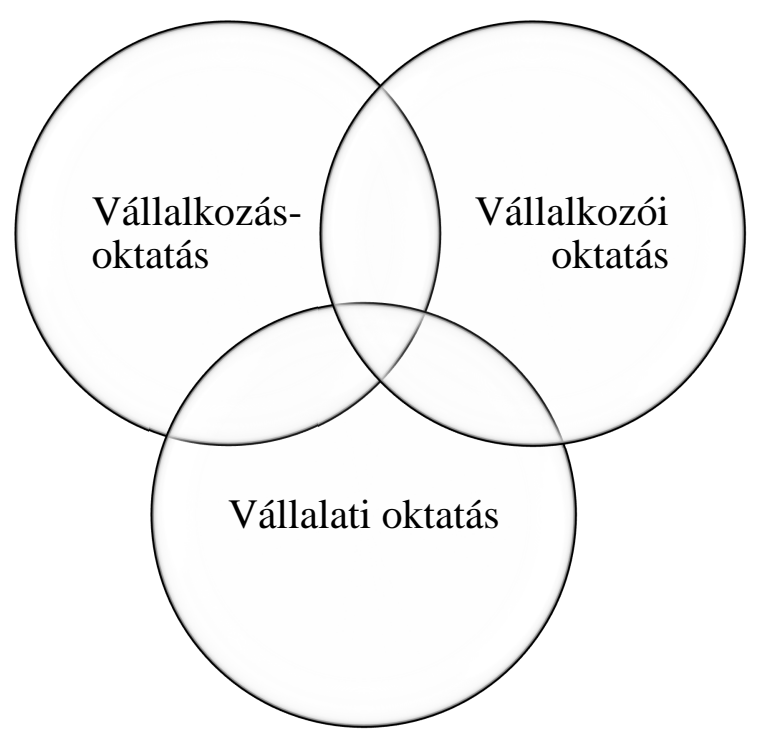

Forrás: Saját szerkesztés

A vállalkozásoktatás a munkahelyteremtés elősegítésének érdekében kialakított új gazdasági stratégiák összetevőjévé válik. A vállalkozásoktatás nagyon fontos eszközzé válik a kockázati tőke és az inkubátorok elérése esetében. Míg a kockázati tőkések a magas növekedési potenciállal rendelkező lehetőségeket, addig az inkubátorok elsődleges ügyfélkörét a start-up vállalatok alkotják. A vállalkozásoktatás még egy fázissal korábbra koncentrál, azaz a 
vállalkozó és a vállalkozás elindulására történő felkészítés problémáira (12. ábra) (McMullan 1987). Az új vállalkozás infrastruktúrájának különböző összetevői hatékonyan kiegészíthetik egymást. Ha a rendszer jól múködik, az oktatási rendszer táplálja az inkubátorokat, melyek pedig táplálják a kockázati tőkéseket. Másrészt, a kockázati tőkések elérhetôsége az inkubátorokba vonzza az embereket, és így a potenciális vállalkozókat az oktatási programokba. A rendszerben fellelhetö közös érdeknek fontosabbnak kell lennie, mint a felelősségek átfedéséből fakadó lehetséges konfliktusoknak.

12. ábra: A vállalkozásoktatás, az inkubátorok és a kockázati tőke összefüggése a vállalkozásfejlesztési folyamattal

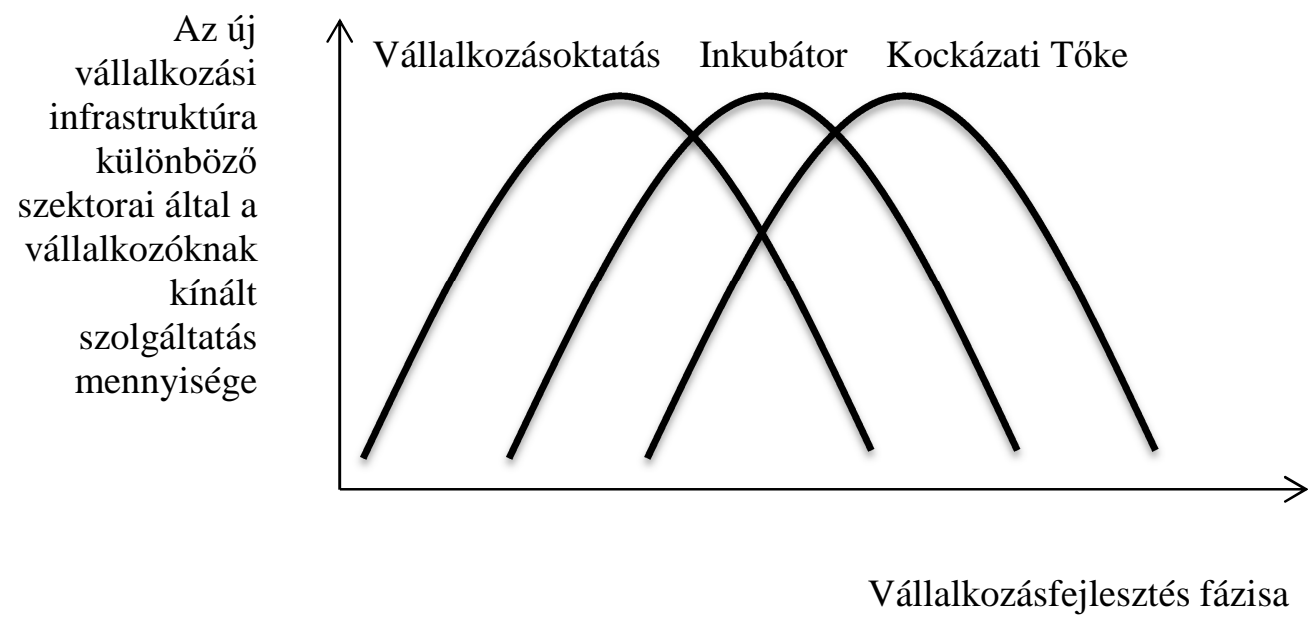

Forrás: McMullan (1987) 264. o. alapján saját szerkesztés

Krueger (2009) szerint két domináns paradigma található az oktatásban (így a vállalkozásoktatáson belül is). A hagyományos „behaviorista” megközelítés a tény alapú tanulásra fókuszál (ezen belül ismétléssel történő memorizálásra, repetitív gyakorlatra és olyan mechanizmusokra, amelyek a tartalmi tudás átadására koncentrálnak). Ebben az esetben az oktatók jellemzően az egyes modelleket, illetve keretrendszereket biztosítják a hallgatók részére. Ezzel ellentétben, a konstruktivista megközelítés a szituatív tanulást helyezi előtérbe, melyben a hallgatóknak saját módszert kell kialakítaniuk a tudás összerendezésére (saját mentális modelljeiket felépítve és átalakítva a tudásnak megfelelően) az ismeretek elsajátítása közben. A szerző kihangsúlyozza, hogy a vállalkozásoktatók egyik legfontosabb feladata az, hogy megfelelő lehetőséget és környezetet biztosítsanak a hallgatók számára ahhoz, hogy ne csak azt változtassák meg, amit gondolnak, hanem azt is, ahogy gondolkodnak (13. ábra). 
A hallgatóknak segíteni kell abban, hogy struktuálni tudják a tudásukat. Ehhez arra van szükség, hogy ehetőségeket kapjanak kritikus fejlödési tapasztalatszerzésre, mely segít újraformálni mentális modelljeiket.

13. ábra: A vállalkozásoktatás tartalma
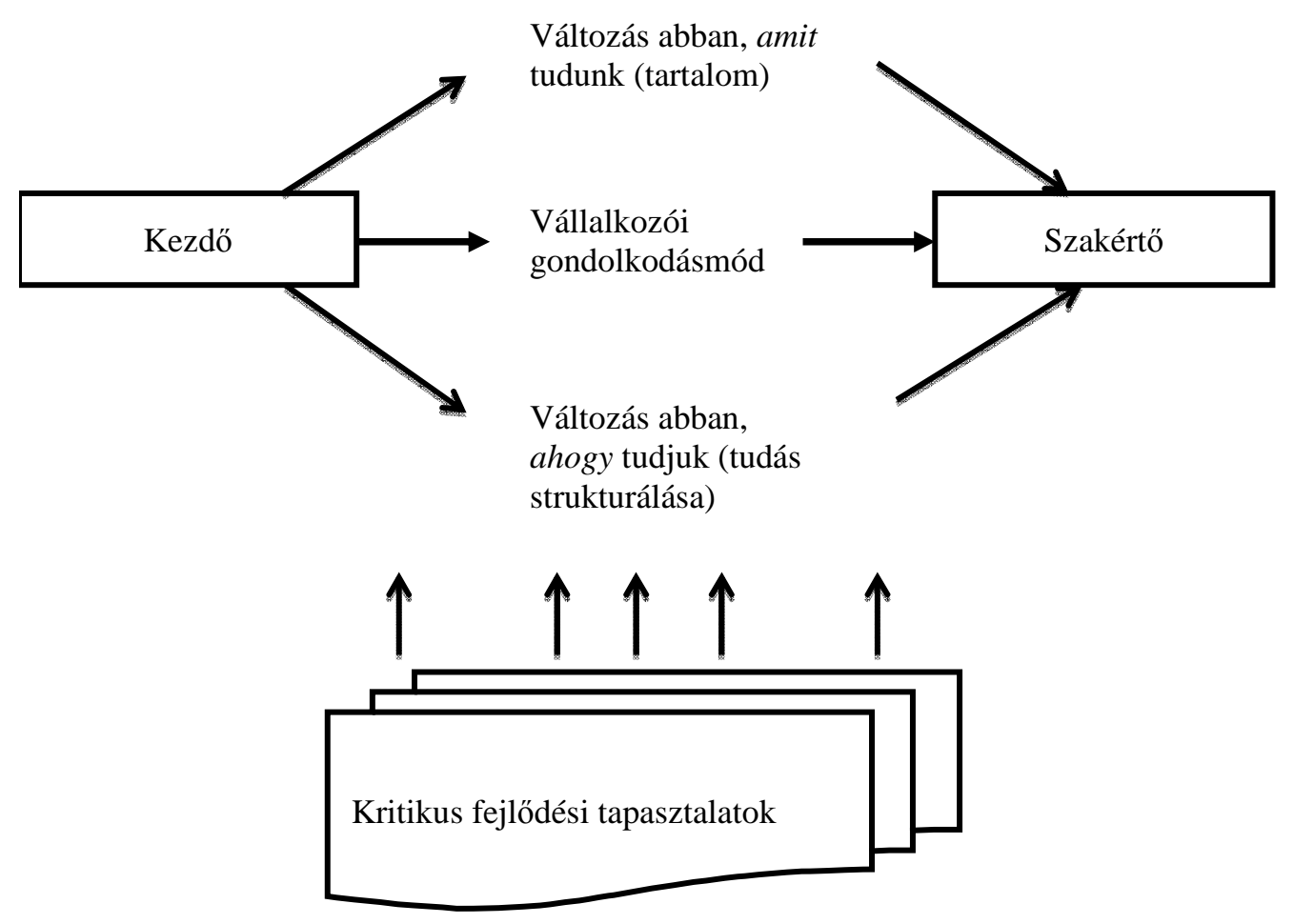

Forrás: Krueger (2009), 38. o. alapján saját szerkesztés

Krueger (2009) egyértelmüen a konstruktivista megközelítés mellett érvel, és azt vallja, hogy „az emberi elme olyan állandó fejlődésben lévö kognitív struktúrák halmazát tartalmazza, amely segít környezetünk és abban betöltött helyünk értelmezésében. Ez magában foglalja a lehetőség észlelését, növeljük a vállalkozói viselkedések lehetőségét, ha növeljük a potenciális lehetőségek észlelt körét. Azonban ha elfogadjuk ezt a kognitív keretrendszert, el kell vetnünk a behaviorista hagyomány nagy részét, amely még mindig uralja az oktatási elméletet és gyakorlatot” (Krueger 2009, 40-41. o.). Következésképpen az egyes tények, módszerek egyszerű memorizálása nem tekinthető tanulásnak és csupán egy-egy vizsga sikeres teljesítése erejéig tart ki. 


\subsection{Vállalkozásoktatás módszertana}

Az egyetemek számára a vállalkozásoktatási programokkal kapcsolatos kihívást a tanterv megtervezése jelenti, amely egyaránt átfogó és integratív a tanulók tanulási igényeinek elősegítése érdekében. A vállalkozói életciklus egyes szakaszaiban megkülönböztetett figyelmet kell fordítani arra, hogy az adott szakaszokban megjelenő problémákat, hogyan kezelhetik a vállalkozók (Kickull-Fayolle 2007). Pusztán a vállalkozási tevékenység új vállalkozás létrehozásának aspektusaira és az erre a szakaszra jellemző problémákra történő koncentrálás a vállalkozói folyamat csupán egy összetevőjét ragadja meg és elhanyagolja a menedzsment és fejlesztés azon meghatározott területeit, melyek fontosak a növekedés későbbi szakaszaiban (például, üzleti érték növelése, foglalkoztatás, menedzsment utódlás).

A vállalkozásoktatási programok általában nem a vállalkozás kialakítására és növekedésére koncentrálnak köré. A pedagógiai áttekintésük alapján Carroll és College például számos kiegészítő módszert ajánl, amelyek között szerepelnek előadások, esettanulmányok, számítógépes szimulációk, üzleti terv kidolgozására irányuló projektek és az üzleti tervek formális bemutatása (Kickul-Fayolle 2007). Habár szükségesek és alapvetőek az új vállalkozás létrehozásához, ezen módszerek általában inkább csak a vállalkozás megalapozására és elindításának korai szakaszaira koncentrálnak. A továbbiakban bemutatom, hogy mire érdemes odafigyelni egy vállalkozásoktatási program kialakítása során.

Elmélet-gyakorlat hangsúlyozása: A vállalkozásoktatási program egyik alapvető célja, hogy olyan tudományosan alapokra fektetett tanulási élményt nyújtson a tanulóknak, mely való életben felhasználható értékké alakul át. Szükség van olyan vállalkozásoktatási elméletek, modellek és módszerek kialakítására és tesztelésére, melyek túlmutatnak a tudományos érdeken azzal, hogy a szakemberre és az oktatóra is egyaránt érvényesek. Egy gyakori módszer, melyet az oktatók az elmélet és a gyakorlat kombinálására használnak, a terep- vagy „élő” esettanulmányi feladat. Az ilyen típusú feladatok során a csapatok átfogó tanulmányt készítenek egy vállalatról, diagnosztikai, értékelő és problémamegoldó készségeket alkalmazva a vállalat kulcsfontosságú stratégiai problémáinak/kérdéseinek felderítésében. Az alapos kutatás elvégzése után a csapat bemutatja ötleteit és ajánlatait az ügyfélnek. Az ügyfelek tanácsadóiként a tanulók sokat tanulhatnak a bonyolult részletekről és összetevőkről, valamint a vállalat irányításához szükséges erőfeszítés mértékéről. 
Többirányú megközelítés: A többfunkciós tanulási perspektíva vállalkozásoktatási programba történő beillesztésén kívül számos mód van arra, hogy a tanulók a tantermen kívül tanuljanak, kommunikáljanak és interakcióban legyenek az oktatóval és más tanulókkal (Kickul-Fayolle 2007). A kommunikációs és információs technológia elérhetősége és hasznossága nő, miközben a szervezetek egymással versenyeznek a legfrissebb információ megszerzéséért a kapcsolódó iparágakban. Ez a technológia jelentős lehetőségekkel bír a hatékonyság növelésére tudás megszerzésében a vállalati képzés és a felsőoktatási környezet területén egyaránt.

Deduktív és induktív tanulás egyaránt meghatározó jelentőséggel bír: Sok oktató állítja, hogy a tartós készségtanulás elérése érdekében a deduktív és az induktív tanulást is hangsúlyozni kell. A deduktív tanulás az a folyamat, amikor a tanuló mások tudását alkalmazza. Azonban ez önmagában nem változtat a vállalkozói készségeken és magatartáson. Az induktív tanulással a tanulók nem feltétlenül lemásolják mások megoldásait, hanem felismerik a vállalkozói problémákat egy új és összetett helyzetben, célokat tűznek ki, akciótervet készítenek és értékelik döntéseik eredményeit. Az induktív tanulás hangsúlyozásával a tanulóknak megvan a lehetőségük arra, hogy ne csak alkalmazzák a tanultakat, hanem kreatív és innovatív megoldásokat fogalmazzanak meg, melyek kizárólagosan egy vállalkozó problémáira/kérdéseire vonatkoznak. A tanuló magatartási formája belülről jön létre, így lehetővé teszi a tanulóknak, hogy önmagukat jobban ösztönzővé váljanak a különböző helyzetekben. A vállalkozásoktatási tanterven belüli induktívabb tanulás hangsúlyozásával az oktatók felkészítik a tanulókat a kétértelmüségekre és átalakulásokra, melyek a saját szervezeteik kialakítása során jelennek meg.

Solomon, Duffy és Tarabishy (2002, idézi Kuratko 2003) folytatták le az egyik legátfogóbb empirikus elemzést a vállalkozásoktatásról. A vállalkozásoktatási pedagógiáról tett áttekintésükben azt állították, hogy a vállalkozásoktatás egyik fő célkitúzése az, hogy eltérjen a tipikus üzleti oktatástól. Az üzleti belépés alapvetően eltérő tevékenység mint egy üzlet irányítása vállalkozásoktatásnak foglalkoznia kell az üzleti belépés bizonytalan jellegével. Ezért a vállalkozásoktatásban szerepelni kell készségfejlesztő kurzusoknak a tárgyalás, a vezetés, az új termék fejlesztése, a kreatív gondolkodás és a technológiai innováció területéröl. 
Egyéb, a vállalkozásoktatásra nézve fontosnak ítélt területek között szerepelt a vállalkozói életpálya lehetőségek ismerete, kockázati tőke-források, ötlet védelem, kétértelműség toleranciája, a vállalkozói személyiséget meghatározó tulajdonságok, és vállalkozásfejlesztés egyes szakaszaira jellemző kihívások. A „tapasztalati tanulás”-nak meghatározó szerepe van a vállalkozásoktatáson belül. Ennek érdekében a legfontosabb eszközök közül Kuratko (2003) az alábbiakat jelöli meg: üzleti tervek, a tanulói üzleti start-upok, konzultáció aktív vállalkozókkal, számítógépes szimulációk, viselkedési szimulációk, interjúk vállalkozókkal, környezeti felmérések, „élő” esetek, tanulmányi kirándulások, valamint videók és filmek alkalmazása.

Ami megkülönböztetheti a vállalkozásoktatás ,alapjait” az üzleti oktatás „alapjaitól”, az a kérdéses helyzetekre fordított figyelem. Az általános közvélekedéssel szemben nem a bizonytalanság tolerálásának képessége a vállalkozás fontos jellemzője, hanem a képesség a bizonytalan helyzetek felvállalására és lehetőséggé alakítására az, ami a sikeres vállalkozóvá válás lényege.

Krueger (2009) a behavorista-konstruktivista megközelítéseket vizsgálja, amelyek között négy alapvető elméletet különböztet meg (5. táblázat).

5. táblázat: A modern pedagógia fejlődésének egyszerüsített áttekintése

\begin{tabular}{|l|l|l|l|}
\hline \multicolumn{5}{|c|}{ (Behavioristább) } \\
\hline \multicolumn{1}{|c|}{ Kulcs elmélet } & \multicolumn{1}{|c|}{ Foltételezés } & \multicolumn{1}{c|}{ Kulcs tevékenység } & Mintaeszköz \\
\hline Tanárszempontú & $\begin{array}{l}\text { Szakértő tanár, passzív } \\
\text { tanuló }\end{array}$ & Memorizálás & Tény-alapú előadások \\
\hline Tanítás szempontú & $\begin{array}{l}\text { Szakértő tanár, aktív } \\
\text { tanuló }\end{array}$ & Készségfejlesztés & $\begin{array}{l}\text { Pro-forma, üzleti } \\
\text { tervek }\end{array}$ \\
\hline Tanulószempontú & $\begin{array}{l}\text { A tanulóknak } \\
\text { kontrollálniuk kell a } \\
\text { tanulási folyamatot (a } \\
\text { tanuló mint vásárló) }\end{array}$ & Tanár-tanuló interakció & Esettanulmányok \\
\hline Tanulás szempontú & $\begin{array}{l}\text { A tanulás metakognitív } \\
\text { értelmezése (a „mit } \\
\text { tudunk”-tól a „hogyan } \\
\text { tudjuk”-ig) }\end{array}$ & Probléma alapú tanulás & Önálló terep projektek \\
\hline
\end{tabular}

Forrás: Krueger (2009), 41. o.alapján saját sszerkesztés

Krueger (2009) azt mondja, hogy az igazi probléma-alapú (problem-based learning) tanulás sokkal több, mint a cselekvés alapú tanulás (learning-by-doing), hiszen a tanulók rá vannak kényszerítve arra, hogy strukturálják a problémát, valamint a szükséges tudást és készségeket. Ezáltal a vállalkozásoktatás során a probléma-alapú tanulás legfontosabb értéke az, hogy 
orientálja a tanulókat a válaszkereséstől a kérdésfeltevésig. A szerző szerint a konstruktivista keretrendszer arra ösztönzi a tanárokat, hogy olyan környezetet hozzanak létre, amely öket és tanulóikat gondolkodásra és felfedezésre sarkallja.

Csapó (2007) a vállalkozásoktatás három alapvető módját különíti el: tanári előadás, szimulált vállakozás, valamint valódi vállalkozás. Ezen formák előnyeit és hátrányait a 6 . táblázat tartalmazza.

6. táblázat: A vállalkozásoktatási módszerek előnyei és hátrányai

\begin{tabular}{|c|c|c|c|c|c|}
\hline \multicolumn{2}{|c|}{ TANÁRI ELÖADÁS } & \multicolumn{2}{|c|}{ SZIMULÁLT VÁLLALKOZÁS } & \multicolumn{2}{|c|}{ VALÓDI VÁLLALKOZÁS } \\
\hline Előny & Hátrány & Előny & Hátrány & Előny & Hátrány \\
\hline $\begin{array}{l}\text { Kiválóan } \\
\text { tervezhető és } \\
\text { lebonyolítható }\end{array}$ & $\begin{array}{c}\text { A vállalkozói } \\
\text { képzést } \\
\text { besorolja a } \\
\text { „szokásos } \\
\text { tantárgyak” } \\
\text { rendszerébe. }\end{array}$ & $\begin{array}{l}\text { Megfelelö } \\
\text { rugalmasság } \\
\text { mellett } \\
\text { tervezhető. }\end{array}$ & $\begin{array}{l}\text { A vásárokra } \\
\text { koncentrálva } \\
\text { kampányszerü } \\
\text { vé válik. }\end{array}$ & $\begin{array}{c}\text { Erős tanulói } \\
\text { motiváció } \\
\text { érhető el. }\end{array}$ & $\begin{array}{c}\text { Nehezen } \\
\text { tervezhetö és } \\
\text { kézben } \\
\text { tartható. }\end{array}$ \\
\hline $\begin{array}{l}\text { Az előadó } \\
\text { diktálja a } \\
\text { témát, nincs } \\
\text { eltérés. }\end{array}$ & $\begin{array}{c}\text { Nehéz } \\
\text { fenntartani a } \\
\text { diákok } \\
\text { érdeklődését. }\end{array}$ & $\begin{array}{l}\text { Jó módszerek } \\
\text { alkalmazá- } \\
\text { sával } \\
\text { játékossá } \\
\text { tehető. }\end{array}$ & $\begin{array}{c}\text { A diákok } \\
\text { számára nem } \\
\text { elég életszagú, } \\
\text { múvinek } \\
\text { látják. } \\
\end{array}$ & $\begin{array}{c}\text { Egyes } \\
\text { képességek } \\
\text { erösen } \\
\text { fejleszthetők. }\end{array}$ & $\begin{array}{l}\text { Igen nagy } \\
\text { felelösség van } \\
\text { a tanáron. }\end{array}$ \\
\hline $\begin{array}{l}\text { Jól mérhető, } \\
\text { értékelhető az } \\
\text { iskolában } \\
\text { megszokott } \\
\text { módon. }\end{array}$ & $\begin{array}{c}\text { Szinte } \\
\text { kizárólag } \\
\text { ismeretekre és } \\
\text { nem } \\
\text { készségekre } \\
\text { koncentrál. }\end{array}$ & $\begin{array}{c}\text { Sokféle } \\
\text { képesség } \\
\text { kifejleszté- } \\
\text { sére alkalmas. }\end{array}$ & $\begin{array}{l}\text { A teljesítmény } \\
\text { iskolai keretek } \\
\text { között } \\
\text { nehezen } \\
\text { mérhető. }\end{array}$ & $\begin{array}{l}\text { Valódi, pl. } \\
\text { iskolai } \\
\text { igényeket is } \\
\text { kielégíthet. }\end{array}$ & $\begin{array}{l}\text { A profit- } \\
\text { orientáció a } \\
\text { tanulás } \\
\text { rovására } \\
\text { mehet. }\end{array}$ \\
\hline $\begin{array}{c}\text { Kevés } \\
\text { pluszköltségg } \\
\text { el jár. }\end{array}$ & $\begin{array}{c}\text { Nehéz a } \\
\text { valóban } \\
\text { „illetékes } \\
\text { szakemberek” } \\
\text { megtalálása. }\end{array}$ & $\begin{array}{l}\text { Relatíve } \\
\text { költség- } \\
\text { kímélő. }\end{array}$ & $\begin{array}{l}\text { A vállalkozói } \\
\text { felelősség } \\
\text { leértékelődik } \\
\text { a szimuláció } \\
\text { által. }\end{array}$ & $\begin{array}{l}\text { Jogilag élö, } \\
\text { rendezett. }\end{array}$ & $\begin{array}{c}\text { Rendkívül } \\
\text { nagy plusz- } \\
\text { terhet ró } \\
\text { diákra, tanárra } \\
\text { egyaránt. }\end{array}$ \\
\hline $\begin{array}{l}\text { Jól illeszkedik } \\
\text { az iskolai órák } \\
\text { megszokott } \\
\text { rendjéhez. }\end{array}$ & $\begin{array}{l}\text { A megtanult } \\
\text { ismereteket a } \\
\text { diákok } \\
\text { gyorsan } \\
\text { elfelejtik. }\end{array}$ & $\begin{array}{c}\text { Jobban } \\
\text { kézben } \\
\text { tartható, mint } \\
\text { a valódi } \\
\text { vállalkozás. }\end{array}$ & $\begin{array}{l}\text { Ritkán elég a } \\
\text { rendelkezés-re } \\
\text { álló } 45 \text { perces } \\
\text { óra. }\end{array}$ & $\begin{array}{l}\text { Iskolán túl is } \\
\text { folytatható. }\end{array}$ & $\begin{array}{l}\text { A magyar } \\
\text { jogrendbe } \\
\text { nehezen } \\
\text { illeszthető. }\end{array}$ \\
\hline $\begin{array}{l}\text { Tanárnak, } \\
\text { diáknak } \\
\text { egyaránt } \\
\text { megszokott. }\end{array}$ & $\begin{array}{l}\text { Úszni nem } \\
\text { lehet csak } \\
\text { könyvből } \\
\text { megtanulni. }\end{array}$ & $\begin{array}{l}\text { Olyan, mint } \\
\text { az úszás } \\
\text { mentőövvel és } \\
\text { parafa- } \\
\text { mellénnyel. }\end{array}$ & $\begin{array}{l}\text { Sokkal inkább } \\
\text { függ a tanuló } \\
\text { hozzáállá- } \\
\text { sától az } \\
\text { eredmény. }\end{array}$ & $\begin{array}{l}\text { A vállalkozói } \\
\text { felelősség } \\
\text { közvetlen, } \\
\text { néha } \\
\text { zsebbevágó. }\end{array}$ & $\begin{array}{c}\text { Sok } \\
\text { tekintetben } \\
\text { kilóg az } \\
\text { iskolai } \\
\text { rendből. }\end{array}$ \\
\hline
\end{tabular}

Forrás: Csapó (2007) alapján saját szerkesztés

A tanári előadás egyértelműen az ismeretek átadására koncentrál, nem igazán alkalmas a vállalkozói készségek fejlesztésére, azonban azoknak egy megfelelő alapot tud biztosítani a 
szükséges elméleti háttér átadásával. A szimulatív vállalkozás esetében már beszélhetünk avállalkozói képességek, készségek fejlesztéséről, hiszen ebben az esetben már gyakorlatban ismerkedhetnek a hallgatók a vállalkozói léttel, anélkül, hogy a valós kockázatokkal számolniuk kellene. Végül, a valódi vállalkozás alapítása során már „kézzelfoghatóvá” válik a vállalkozói létforma, hiszen a hallgatók megtapasztalják, hogy milyen vállalkozónak lenni. Az egyes típusok előnyeinek és hátrányainak boncolgatása számos tényező függvénye (hallgatók motivációja, „vállalkozói véna” megléte, leterheltség foka stb.), így én nem részletezném az egyes pro és kontra tényezöket, mert szerintem nem lehet általánosítani, hiszen minden kar, minden szakirány, minden kurzus, sőt minden évfolyam egyedi jellegzetességeket hordoz. Véleményem szerint a három módozatnak egymásra épülése hatékony vállalkozásoktatást eredményezhet. A valódi vállalkozás rendkívül hatékony eszköz lehet a vállalkozói készségek, képességek fejlesztésében, azonban önmagában, a szükséges elméleti megalapozás nélkül már nem biztos, hogy ugyanolyan eredményeket ér el.

\subsection{Nemzetközi kitekintés: vállalkozásoktatás az USA-ban és Európában}

Az Egyesült Államok felsőoktatási intézményeiben tartott vállalkozásoktatási programok skálája az alapkurzusoktól a vállalkozástudományi programokon keresztuil a kutatóközpontokig terjedhet.

A Kauffman Alapítvány nemrég kiemelte a vállalkozásoktatást a felsőoktatási intézményekben a „Kauffman Campuses kezdeményezés” keretében. A kezdeményezés küldetése a felsőoktatás ,átalakítása” a vállalkozói képzés hallgatók számára történő biztosításához, a nemzetgazdaság erősítésének érdekében. A Kauffman Campuses kezdeményezés részeként az egyetemek a vállalkozástudományi programokat a hagyományos üzleti iskoláktól az interdiszciplinárisabb megoldások felé kezdték mozdítani. A támogatott programok célja elsősorban vállalkozói készségek a foglalkoztatottak minél nagyobb hányadához történő eljuttatása.

A vállalkozásoktatás elősegítheti a vállalkozói és innovatív kultúra kialakítását Európában a gondolkodásmód megváltoztatásával és a szükséges készségek biztosításával. Az amerikai és az európai vállalkozásoktatás közötti föbb különbségek egyike a vállalkozási kurzusok meghatározása és fókusza (Wilson 2008). Az Egyesült Államokban az „entrepreneurship” kifejezés általában a növekedésorientált vállalkozásokra fókuszál, míg Európában gyakran a KKV-kal azonosítják. Európában vállalkozások 99,9\%-a kis- és középvállalkozás, ezen belül 
is jellemzően megjelennek a csalási vállalkozások. Ezen vállalatok nagy és igen jelentős szerepet játszanak az európai gazdaságban, azonban a KKV-k nagyon kis hányada növekedésorientált, „gazella” vállalkozás. Ez a definíciós különbség azt jelenti, hogy Európában sok ,entrepreneurship” program valójában KKV képzési program, amely a kisvállalkozásokhoz szükséges funkcionális menedzsment készségekre koncentrál (Wilson 2008), nem pedig a gyors növekedésű vállalatok kiépítéséhez, finanszírozásához és fejlesztéséhez szükséges készségekre.

Egy másik alapvető különbség a vállalkozástudomány helye az egyetemen és általánosabban az akadémián belül. Míg a vállalkozástudomány még mindig nem teljesen elfogadott mint tudományág, az Egyesült Államokban számos üzleti iskola alakított kínál különböző szakokat vállalkozásoktatási területen. Számos amerikai egyetem rendelkezik egyetemi vállalkozástudományi tanszékkel és kínál vállalkozástudományi kurzusokat.

Európában a vállalkozástudomány még mindig keresi a helyét. Az alaptevékenységek Európaszerte megtalálhatóak, azonban gyakran külső szereplők által vezéreltek, így a vállalkozástudomány oktatóinak belső csatákat kell megvívniuk a tevékenységek támogatásának és finanszírozásának érdekében. A vállalkozástudományi professzorok többsége Európában hagyományos előadó, amely a régóta fennálló irányelveket és gyakorlatokat tükrözi. Az intézményi kultúra, a gyakorlat és a rögzített irányelvek gyakran állnak a vállalkozói szellem és egyáltalán a vállalkozásbarát környezet útjába az egyetemeken belül. A vállalkozástudomány támogatói döntő szerepet játszanak az egyetemeken belül, azonban az egyetem vezetőinek erőteljes elkötelezettségére is szükség van (igazgatók, rektorok). Erre teljes paradigmaváltásra van szükség az egész egyetemre nézve, beleértve az egyetem alapvető müködésének és társadalmi szerepének megváltoztatását.

Egy másik alapvető különbség Európa és az USA között az a mód, ahogy az egyetemek az oktatásra tekintenek. Számos amerikai egyetemen a vállalkozástudományt a multidiszciplináris oktatási folyamat szerves részének tekintik. A hallgatókat arra ösztönzik, hogy más tudományterületen (mérnöki tudományok, művészetek, üzleti tudomány stb.) lévő hallgatókkal közös projekteket készítsenek így lehetővé téve, hogy az egész egyetem területéről szerzett szakértelemre támaszkodjanak. Az egyetemek arra törekednek, hogy minimalizálják az intézményi korlátokat a multidiszciplináris tevékenységekre nézve a 
legkreatívabb és leginnovatívabb tanulási folyamat lehetővé tételének érdekében. Az eredmény egy dinamikus csapat- és projektalapú tanulási környezet.

Egyéb különbségek találhatóak a tanuláshoz való hozzáállásban és megközelítésben. Az Amerikai Egyesült Államokban a vállalkozásoktatás nagyon szorosan kapcsolódik az üzleti gyakorlathoz. A professzorok gyakran rendelkeznek start-upokkal kapcsolatos tapasztalatokkal. A vállalkozók, akik közül sokan az egyetem végzett hallgatóiból kerülnek ki, részt vesznek a tanórai tevékenységben tanulókkal való beszélgetés vagy kurzus oktatásának formájában. Ezen kurzusok struktúrája a lehető leggyakorlatiasabb, való életbeli eseteket, projekteket, gyakorlatokat és üzleti terv versenyeket foglal magába. Az esettanulmányok a vállalkozói életpályát fontolgató tanulók számára példaképként is szolgálnak. Ez a vállalkozói attitüd kialakításának fontos része: ha a tanulók látják, hogy a hozzájuk hasonló emberek képesek voltak sikeres vállalatok létrehozására, segít demisztifikálni a folyamatot és megvalósíthatóbbá tenni ezt a választási lehetőséget.

Míg interaktív módszereket, melyek általában projektalapúak, szintén alkalmaznak Európában, a legtöbb vállalkozástudományi kurzust még mindig a tantermi előadás módszerével tanítanak. Esettanulmányokat néha használnak, viszont azok ritkán koncentrálnak európai vállalkozókra mint potenciális példaképekre. Több sikeres vállalkozókat szerepeltető európai esettanulmányt kell kidolgozni és széles körben megosztani az iskolákban Európa-szerte. Több alkalommal kellene ezen vállalkozókat bemutatni a médiában annak érdekében, hogy szélesebb körben találkozzanak az emberek ilyen példaképekkel.

Az előzőekben Európa alatt egyértelmüen Nyugat-Európát értettem, azonban az utobbi években egyre inkább előtérbe kerül a vállalkozásoktatás támogatása Közép- és KeletEurópában, hiszen ezen országokban egyre inkább felismerik a nemzeti gazdaságok újjáépítésének, új technológiák átvételének és a munkahelyteremtés alapvető fontosságát, valamint a vállalkozások szerepét e folyamatokban (Zahra-Welter 2008). A közép- és keleteurópai országok versenyképességének növelése, valamint tudásalapú gazdasággá válása érdekében számos kihívással kell szembenézniük, amiben a vállalkozásoktatás nagy szerepet játszhat (7. táblázat). 
7. táblázat: A vállalkozásoktatás lehetőségei és kihívásai Közép-, Kelet-, és DélkeletEurópában - Javaslatok a felsőoktatási intézmények számára

\begin{tabular}{|c|c|c|}
\hline Dimenziók & Kérdéskör & Javaslatok \\
\hline Lehetőségek & $\begin{array}{l}\text { - Fiatal lakosság: új vállalkozás } \\
\text { létrehozásának igénye (lehetőség vs. } \\
\text { igény). } \\
\text { - Technológia felzárkózás } \\
\text { szükségessége. } \\
\text { - Gazdasági fejlődés: életszínvonal } \\
\text { növekedése. } \\
\text { - Kiváló matematikai és mérnöki } \\
\text { háttér. } \\
\text { - Külföldi befektetések áramlása. }\end{array}$ & $\begin{array}{l}\text { - Korai kezdés, a kreativitási } \\
\text { módszerek alapkészségeivel. } \\
\text { - Kapcsolatok vállalatokkal, } \\
\text { tapasztalataikat megosztó } \\
\text { vendégelőadók személyében. } \\
\text { - Technológia-alapú vállalkozásokra } \\
\text { történő fókuszálás. }\end{array}$ \\
\hline Kihívások & $\begin{array}{l}\text { - Állami tulajdon öröksége - } \\
\text { privatizáció lehetőségeket teremt. } \\
\text { - Ösztönzők hiánya. } \\
\text { - Tőke/finanszírozás. } \\
\text { - Oktatók hiánya - Meglévő tanári kar } \\
\text { megújítása. } \\
\text { - Vállalkozói kultúra hiánya - } \\
\text { Példaképek. } \\
\text { - A tudományos intézmények } \\
\text { elméleti/absztrakt jellegủek. } \\
\text { - Hogyan kellene belevágni. } \\
\text { - Tudomány/technológia } \\
\text { összekapcsolása üzleti programokkal. }\end{array}$ & $\begin{array}{l}\text { - Az oktatásnak a nagy múltú } \\
\text { vállalatokat és az új vállalkozásokat } \\
\text { egyaránt meg kellene céloznia. } \\
\text { - A vállalkozásoktatás kulcsszerepe a } \\
\text { változás lehetőségének } \\
\text { megteremtésében rejlik; a fejlődés kis } \\
\text { lépésekkel kezdődik, melyeket } \\
\text { újabbak követnek és a lendület } \\
\text { felgyorsul. } \\
\text { - Helyi vállalkozók példaképként, } \\
\text { illetve visszajelzési és tanulási } \\
\text { forrásként történő bevonása. } \\
\text { - Közös programok létrehozása, ahol } \\
\text { tudomány/technológia képviselői és } \\
\text { vállalkozások találkozhatnak. }\end{array}$ \\
\hline
\end{tabular}

Forrás: Zahra-Welter 2008, 182. o. alapján saját szerkesztés

Ahogy a táblázatból is jól látszik, a vállalkozásoktatás számos ponton megjelenhet és segíthet az egyes kihívások megoldásában.

\subsection{Hazai kitekintés: vállalkozásoktatás Magyarországon}

Hazánkban a rendszerváltás után és főként a 2000-es években a felsőoktatásnak éppúgy számos kihívással kellett szembenéznie, mint a nyugati országoknak. Egyrészről beszélhetünk a hagyományos oktatási szerep változásáról, hiszen a szűk elitképzést felváltotta a sokkal szélesebb tömeget magába foglaló tömegképzés. Másrészről az egyetemek változó szerepvállalása értelmében „elvárt, hogy az egyetemek a gazdaságfejlesztéshez, kutatásfejlesztéshez és a helyi regionális fejlödéshez is járuljanak hozzá.” (Szerb-Márkus 2007a, 29. o.) Ami a vállalkozásoktatás kicsit sem pozitív helyzetét illeti Szirmai-Csapó (2006, 78. o.) megjegyzi, hogy „A rendszerváltást megelözö években a magyar felsőoktatási intézmények képzési palettáján nemhogy a vállalkozási ismeretek oktatását célul kitüzö kurzusok nem szerepeltek, Magyarországon kiterjedt gazdasági felsőoktatás sem volt.” 
Végül, a vállalkozásoktatás jelentőségét - a nyugati fejlett országokhoz képest kicsit lemaradva - hazánkban is felismerték és egyre több publikáció, felmérés születik a témában. Így például Román (2006) a magyar vállalkozásoktatás helyzetét vizsgálta a felsőoktatási intézményeken belül. A legfontosabb következtetése egybecseng a korábbi szakirodalmi áttekintés során is előkerülő problémával, azaz a gazdasági felsőoktatásban tanuló hallgatók alapvetően menedzsment-ismeretekre tesznek szert és csak kis mértékben jutnak hozzá valódi vállalkozói ismeretekhez, ezt is legtöbbször választható formában. Továbbá, a kutatásból kiderült, hogy a hallgatók tapasztalati tanulását támogató gyakorlati képzésre még kevés a hazai példa, mindössze egy gazdasági és egy nem-gazdasági kar jelezte, hogy ilyen jellegü tevékenységet folytatnak.

Novotny (2011) kutatása során azt vizsgálta, hogy a magyar egyetemek mennyire tudnak megfelelni a tudományos vállalkozói tevékenységek (harmadik küldetés) egyetemi alapfeladatok közé történő beépítésének. Az eredményekből kiderül, hogy az általa megkérdezett kutatók túlnyomó része elfogadja, hovatovább elkötelezett a harmadik küldetés felé, azonban relatíve kevesen vesznek részt abban, tehát konkrét cselekedet formájában még nem történtek jelentős előrelépések.

Barakonyi (2009) a magyar üzleti oktatással kapcsolatosan kihangsúlyozza, hogy alapvető követelmény a tudás és a gyakorlat megfelelő módon történő integrálása. Továbbá ezt továbbgondolva kijelenti, hogy „a szakmai ismeretek színvonalas oktatása, a gyakorlattal kialakitott szorosabb kapcsolat és visszacsatolás, az ismeretközlés mellett a képességek, készségek fejlesztésének erösítése nem mond ellent a tudás generálásának és transzferjének.” (Barakonyi 2009, 12.o.) Ezt a gondolatot nagyon fontosnak tartom és a későbbi keretrendszer kidolgozása során is egyik központi szerepet kap a gyakorlat, illetve azon keresztül a készségek fejlesztésének szükségessége. Nyilvánvalóan a megfelelő arányok megtalálása, eltalálása minden esetben egy tanulási folyamat eredménye. Továbbá, úgy gondolom, hogy az ismeret-gyakorlat-készségek mellett legalább ugyanolyan fontos a vállalkozói szemlélet, attitűd kialakítása és formálása is.

A vállalkozásoktatás jelentősége nemcsak a vállalkozóknak átadott tudás új vállalkozásokba történő beépítésénél jelenik meg, hanem ahogy Csapó (2007) kiválóan rávilágít „tágan értelmezve a vállalkozói szemlélet mint egyfajta viselkedés- és magatartásforma is felfogható, ami a mindennapi élet minden területén alkalmazható” (Csapó 2007, 31.o.). Ezzel a 
gondolattal teljes mértékben egyetértek, hiszen nem „csupán” a vállalkozóknak van szüksége a vállalkozói szemléletre, hiszen a társadalom minden szintjén és minden területén felhasználható „tudás- és kompetencia csomag” egy-egy szelete. Az alapvető pénzügyiszámviteli ismeretekre éppúgy hasznosak egy tanár számára, illetve a tipikus vállalkozói kompetenciák (döntéshozatal, kreativitás, önállóság, problémamegoldás stb.) az élet számos területén szükségesek.

Szerb és Márkus (2007a) a vállalkozóvá válás és a felsőoktatási környezet közötti kapcsolatot vizsgálta. A kutatásaikból kiderült, hogy a felsőoktatási képzés és a vállalkozói hivatás választása pozitív korrelációt mutat. A szerzők több vizsgálatot is végeztek a témában (Szerb-Márkus 2007a, 2007b), amely során arra az eredményre jutottak, hogy pozitív hatás fedezhető fel a vállalkozói kurzusokat felvevők és a vállalkozói karriert választók között. Ugyanígy Gubik (2013) kutatásai is alátámasztják a képzés vállalkozásindításra gyakorolt hatását, rendkívül szemléletes példa, hogy egy további felvett egy vállalkozói kurzus felvétele 13\%-kal növeli annak az esélyét, hogy egy hallgató vállalkozásindítást tervezzen. A vállalkozóvá válás elősegítésének és új vállalkozás létrehozásának szentelt tantervek és programok közelmúltbeli növekedése és fejlesztése figyelemre méltó. Nemzetközi összehasonlításban a GUESSS-felmérés egy interpretációjában megállapítást nyert, hogy a vállalkozásoktatás területén a nemzetközi átlagnak megfelelő képzési kínálattal rendelkezik a hazai felsőoktatási intézmények többsége (Petheő 2013). Ezért a hazai gyakorlatban a mennyiségi fejlődést érdemes lenne minőségi fejlődéssé formálni.

A közismert GUESSS kutatás keretein belül számos esetben megállapítás nyert, hogy az egyetemek elsősorban vállalkozói kurzusok biztosításával járulhatnak hozzá a hallgatók vállalkozóvá válásához és a vállalkozások jövőbeni sikerességéhez (Szerb-Lukovszki 2013). Azaz nem csak a vállalkozások indítására lehet hatással az egyetemi oktatás, hanem a vállalkozások hosszabb távú fennmaradására is. Ez egy nagyon fontos gondolat, hiszen legtöbbször a vállalkozásalapítással kapcsolatos törekvésekről van szó, azonban a vállalkozás müködtetése, fejlesztése lényegesen nagyobb kihívást jelent és megfelelő ismereteket igényel.

Ahogy már korábban is láthattuk az Európai Unióban kiemelt jelentőséggel bír a vállalkozóvá válás elősegítése. Az elmúlt évtizedben hazánkban is számos, vállalkozás létrehozására, tudásintenzív vállalkozásalapításra irányuló külső támogatással találkozhattunk. Ezek szándéka egyértelmüen pozitív, azonban az esetek meghatározó hányadában 
vállalkozásoktatás nem kapcsolódott az egyes programokhoz ${ }^{3}$. Meggyőződésem, hogy nagyban növelné az ilyen jellegű programok hatékonyságát ha minőségi vállalkozásoktatás is párosulna azokhoz. Mindez összecseng Kállay-Imreh (2004) gondolataival, azaz „a versenyhátrányt nem valamilyen jövedelemtranszferrel kell ellensúlyozni, hanem a támogatásra érdemes vállalkozások versenyképességét kell növelni.” (Kállay-Imreh 2004, 70. o.) Véleményem szerint éppen ebben a versenyképesség-növelésben játszhat meghatározó szerepet a hatékony vállalkozásoktatás, ezen belül is a vállalkozók - kockázati tőke bevonásra, külpiacra lépésre - történő felkészítése.

\section{9. Összegzés}

Ebben a fejezetben áttekintettem a vállalkozásoktatás fogalmát, céljait, módszertani lehetőségeit, illetve nemzetközi és hazai kitekintés során igyekeztem feltárni a jelenlegi helyzetet.

A téma szakértői a mai napig vitatják, hogy a „vállalkozás tudámányát” lehet-e oktatni, lehete vállalkozóvá nevelni valakit, vagy vállalkozónak születni kell-e. Akiből ugyanis hiányoznak az alapvető személyiségjegyek, azt nagyon nehéz vállalkozóvá formálni. Azonban ha meg is vannak rejtetten a kellő tulajdonságok és motivációk - az egyén azt hozta magával -, akkor sem biztos, hogy felszínre kerülhet, hiszen az adott környezet, kultúra ezt adott esetben elnyomhatja. Az oktatók viszont nagy szerepet vállal(hat)nak az egyének kibontakozásában, hiszen a képzettség, a szakmai ismeretek és tapasztalatok (azaz a fejleszthető és tanulható tényezők) ugyanannyira fontosak, mint az egyénnel született adottságok. Mindent összevetve a „vállalkozás tudományának taníthatóságával” kapcsolatban a szakirodalom állításaival összhangban, úgy gondolom, hogy a vállalkozástudomány csak meghatározott aspektusai taníthatóak. Ahogy Howard Stevenson, a Harvard Egyetem professzora kifejezően megfogalmazta: „Nem tudsz valakit arra tanítani, hogyan legyen Bill Gates, (és azt sem) hogyan komponáljon úgy, mint Beethoven. Viszont megtanithatod az eszközöket, amelyek szükségesek ahhoz, hogy vállalkozó legyen.”

Ahogy a fentebbiekből is jól látszik vállalkozásoktatás fogalma, céljai nehezen megfoghatóak, hiszen minden kontextusban eltérő jellegzetességei vannak. Beszélhetünk

\footnotetext{
${ }^{3}$ Erre példa regionális operatív programok keretén belül 1.3.1-12 „A régió innovációs potenciáljának fejlesztése innovatív start-up cégek létrehozásával” c. pályázat, ahol - biotechnológia, informatika stb. szektorban tevékenykedő - öteletekkel rendelkező pályázók vállalkozásalapítását és működtetését nagyban segítethette volna a vállalkozásoktatás keretében átadható ismeretanyag.
} 
vállalkozásoktatásról tágabb értelmezésben, mint szervezet formális gazdasági oktatás és le lehet szűkíteni vállalkozásoktatás tárgyakra (14. ábra).

14. ábra: Vállalkozásoktatás helye

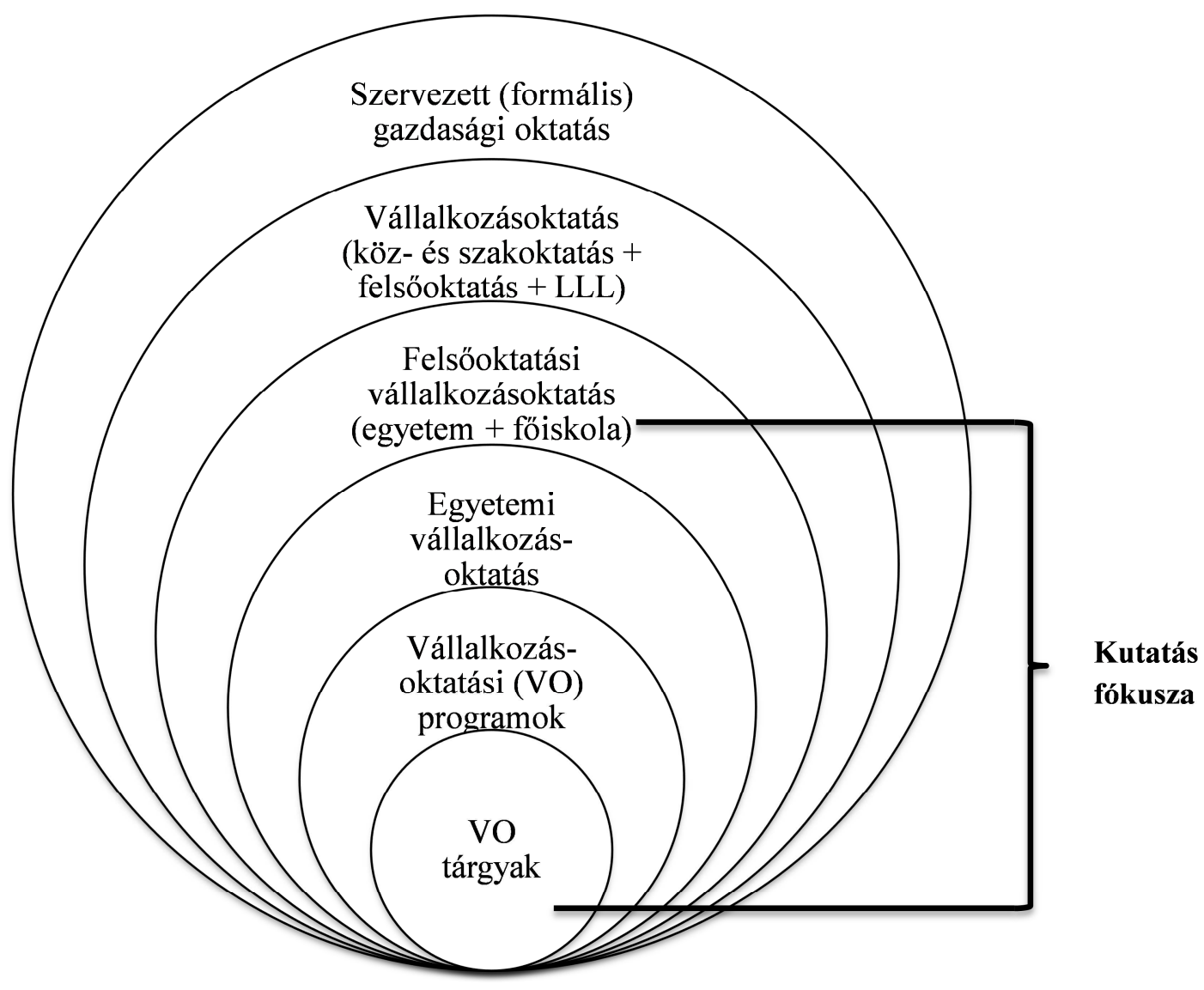

Forrás: Saját szerkesztés

Dolgozatomban elsősorban az egyetemi vállalkozásoktatást vizsgálom, hiszen célom a Szegedi Tudományegyetem által adaptálható módszerek és példák vizsgálata. Azonban, amennyiben az Egyesült Államokbeli, valamint nyugat- európai intézményeket nézünk ez a határvonal kissé eltolódik a „Felsőoktatási vállalkozásoktatás”-ba, hiszen ezen országokban főiskolák is kimagasló eredményeket érnek el a vállalkozásoktatás területén (ld. Babson College). Ezzel szemben amennyiben hazánkra szükítjük le a kört, akkor egyértelmúen egyetemi vállalkozásoktatásról beszélünk, hiszen főiskolai szinten még nagyon messze járunk az amerikai gyakorlattól.

Az eddigiekben rávilágítottam a vállalkozásoktatás legfontosabb aspektusaira. A tényleges gazdaságfejlesztési összefüggéséhez fontos megvilágítani, hogy az egyetemek szélesebb kontextusban hogyan kapcsolódnak a regionális gazdasághoz, hogyan alakult át szerepük az 
utóbbi évtizedben, illetve hogyan jelenik meg megváltozott küldetésükön belül a vállalkozásfejlesztési szerepvállalás is.

A felsőoktatási intézmények fontos szerepet játszhatnak a vállalkozói készségek tanításában a fiatalok számára, növelve azok számát, akik esetlegesen vállalatokat indítanak és eredményesen fejlesztik azokat. A vállalkozókészség növekedését egyetemi spin-offok és kisvállalatokkal történő kutatási együttműködések támogatásával is elősegíthetik. A társadalom és a felsőoktatási intézmények számára történő előnyök eléréséhez azonban változtatni kell a múltbeli gyakorlaton annak érdekében, hogy az egyetem nagyobb fokú vállalkozói elképzeléssel rendelkezzen, amely jobban illeszkedik napjaink gazdaságához és társadalmához.

A vállalkozásoktatást nem egy csodaszer, nem arról van szó, hogy abból, aki felvesz és teljesít bizonyos kurzusokat egyértelmüen sikeres vállalkozó lesz. Ahogy én látom az egyetemi vállalkozásoktatás arról szól, hogy a hallgatók vállalkozói attitüdformálása történik meg. A hallgatók belelátnak abba, hogy mit is jelent vállalkozónak lenni, mivel jár ez az életforma (függetlenség, felelősség, rugalmasság, ötletelés stb.). Sok esetben a vállalkozói lét a hallgatók számára megfoghatatlan, föleg akkora, ha közvetlen környezetükben nincsenek vállalkozók. Véleményem szerint a vállalkozásoktatásnak két alapvető szerepe van: egyrészt a hallgatók egyfajta önismeret során felismerik magukban, hogy alkalmasak-e a vállalkozói létformára (vagy inkább alkalmazott típusba tartoznak), azaz vállalkozónak látják-e magukat? A kérdésre adott válasz inkább a kurzusok során derüljön ki, mint a „,való életben”. Másrészt a vállalkozói vénával rendelkező hallgatók számára egy olyan (elméleti és gyakorlati) tudás és - ami talán még fontosabb - vállalkozói gondolkodás biztosítása, amely segíti őket a vállalkozásalapítás és müködtetés során. Bármelyik szerepet is vizsgáljuk, azt látni kell, hogy gyakorlati oktatás nélkül egyik sem valósulhat meg eredményesen, hiszen markáns különbség van aközött, hogy elolvasunk egy megoldást egy adott problémáról, vagy megtalálunk egy megoldást egy adott problémára. Mindkettő nagyon fontos és kétségkívül egymást erősítő tényező, következésképpen mindkettőnek helye van a vállalkozásoktatásban - a kérdés az, hogy milyen arányban.

Hazánkban, kissé lemaradva, de a 2000-es évek elején elkezdődött a nyugati országokhoz történő felzárkózás, azonban úgy tünik, hogy ez egy meglehetősen lassú folyamat. A hazai vezető felsőoktatási intézményekben valamilyen formában találkozhatunk vállalkozásoktatási 
kezdeményezésekkel, azonban ezek egyelőre még megrekedtek a próbálkozások szintjén, aminek nyilván számos oka lehet úgy, mint megfelelő (pénzügyi, humán) erőforrás hiánya, az egyetemek vállalkozásoktatás felé történő elkötelezettségének hiánya, megfelelö vállalkozásoktatási stratégia/policy/keretrendszer hiánya stb. Vélhetően ez a jövőben változni fog, hiszen egyre többen foglalkoznak hazánkban is ezzel a területtel, emellett a hazai, illetve az európai uniós politika egyik meghatározó részterülete a vállalkozóvá válás ösztönzése, föként a fiatalok körében.

Jelenleg a vállalkozásoktatás még egy meglehetősen fiatal és kiforratlan kutatási terület. Nem létezik egységes definíció, keretrendszer, modell, módszertan és láthattuk, hogy jelentős különbségek vannak a tevékenység értelmezésében Amerikában és Európában. Mindez összességében nem könnyíti meg a helyzetet amennyiben egy vállalkozásfejlesztésivállalkozásoktatási modell alapjait szeretnénk lerakni, habár az eddig áttekintett szakirodalom számos kiindulópontot is szolgáltat. A legjellemnzőbb motívumok: a felsőoktatás egyértelmüen segítheti a vállalkozóvá válást, a hatékony vállalkozásoktatáshoz elengedhetetlen a vállalkozó készségek, kompetenciák fejlesztése, megfelelő elméleti háttér nélkül nem lehet mire építkezni, illetve ismeretátadás-gyakorlati oktatás megfelelő arányának kialakításával eredményes vállalkozásoktatás érhető el. A továbbiakban ezen támpontok, szempontok mentén vizsgálódok és mind a szekunder, mind a primer kutatás során bízom benne, hogy körvonalazódni látszanak majd a Szegedi Tudományegyetem vállalkozásfejlesztési-vállalkozásoktatási modelljének keretei. 


\section{Vállalkozásoktatási modellek}

Az előző fejezetekben bemutattam, hogy a vállalkozásoktatás meglehetősen fontos szerepet játszik mind a vállalkozóvá válás elősegítésében, mind a gazdaságfejlesztésben. A vállalkozó egyetem és a hatékony vállalkozásoktatás nagymértékben hozzájárulhat egy régió versenyképességének növeléséhez. Azonban felvetődik a kérdés, hogy vajon milyen elvek mentén, milyen modellek alapján lehet eredményes vállalkozásoktatási tevékenységet folytatni. Éppen ezért a negyedik fejezetben áttekintem a szakirodalomban fellelhető vállalkozásoktatási modelleket. A vizsgálatom során az alábbi kérdésekre keresem a választ a későbbi keretrendszer kidolgozása érdekében:

1. Egy gazdasági felsőoktatási intézmény/egyetem hogyan tudná segíteni hatékonyan és eredményesen a hallgatók vállalkozóvá válását?

2. A vállalkozásoktatáson belül milyen kompetenciákat kellene fejleszteni?

3. A vállalkozásoktatáson belül a tényleges hatékony vállalkozóvá válás érdekében milyen ismereteket érdemes oktatni?

4. Milyen oktatás-módszertani hátteret tartanak a legeredményesebbnek a hatékony vállalkozásoktatás megvalósítása érdekében?

\subsection{Lourenco vállalkozásoktatás modellje}

Lourenco (2013) a vállalkozásoktatás diplomások vállalkozóvá válásának növekedésben betöltött szerepét vizsgálja az Egyesült Királyságban, valamint meghatározza azokat az alapelveket, amelyek elősegítik ezt a folyamatot. A vállalkozásoktatást fontos tényezőnek tekintik a diplomások vállalkozóvá válásában, valamint a változékony, komplex és bizonytalan üzleti környezetben történő foglalkoztathatóságuk elősegítésében. Az üzleti iskolák sok esetben egy kaptafára készült, „,dobozos” oktatási termékeket kínálnak, amelyek nem alkalmazhatóak egyformán a különböző karokon, tudományterületeken lévő hallgató esetében, amely hatással lehet a karok közötti hatékony együttmüködésre. A szakirodalom alapján a vállalkozásoktatásnak két alapvető formája van:

1. vállalkozásról történő oktatás; és

2. vállalkozásra oktatás.

A vállalkozásról történő oktatás leíró jellegü, és kizárólag a vállalkozásról nyújt ismereteket a hallgatóknak. Ahogy már korábban is említettem az ilyen típusú oktatást meglehetősen sok kritika érte, mivel túlhangsúlyozza az elméleti oktatást, valamint a gyakorlati tudást 
eredményként, mintsem eszközként kezeli. Továbbá az effajta megközelítés korlátozza a vállalkozói készségek, képességek és tulajdonságok fejlesztését (Gibb 2010). Ezzel szemben a vállalkozásra oktatás célja a hallgatók vállalkozói szelleművé válásának, valamint magának vállalkozóvá válásnak ösztönzése és elősegítése (Laukkanen 2000). Az oktatás ezen formája konstruktívabb pedagógiát alkalmaz, mely során a tanulást a tanulók a cselekvési folyamat során valósítják meg.

A vállalkozásoktatás (ebben az esetben vállalkozásra oktatás) keretrendszere alapján a vállalkozói folyamat négy szakaszból áll. A kezdeti szakasz az ötletek és lehetőségek beazonosításáról, felismeréséről és megteremtéséről szól. A második szakasz a lehetőségek kiválasztására, érvényesítésére és értékelésére vonatkozik. A harmadik fázis a lehetőségek fejlesztése, véglegesítése és működtetése. Az utolsó szakasz a lehetőségek kiaknázása és az indulás utáni (post-start-up) szempontok fázisa (15. ábra).

15. ábra: Vállalkozásoktatás modellje

\section{Vállalkozásoktatás}

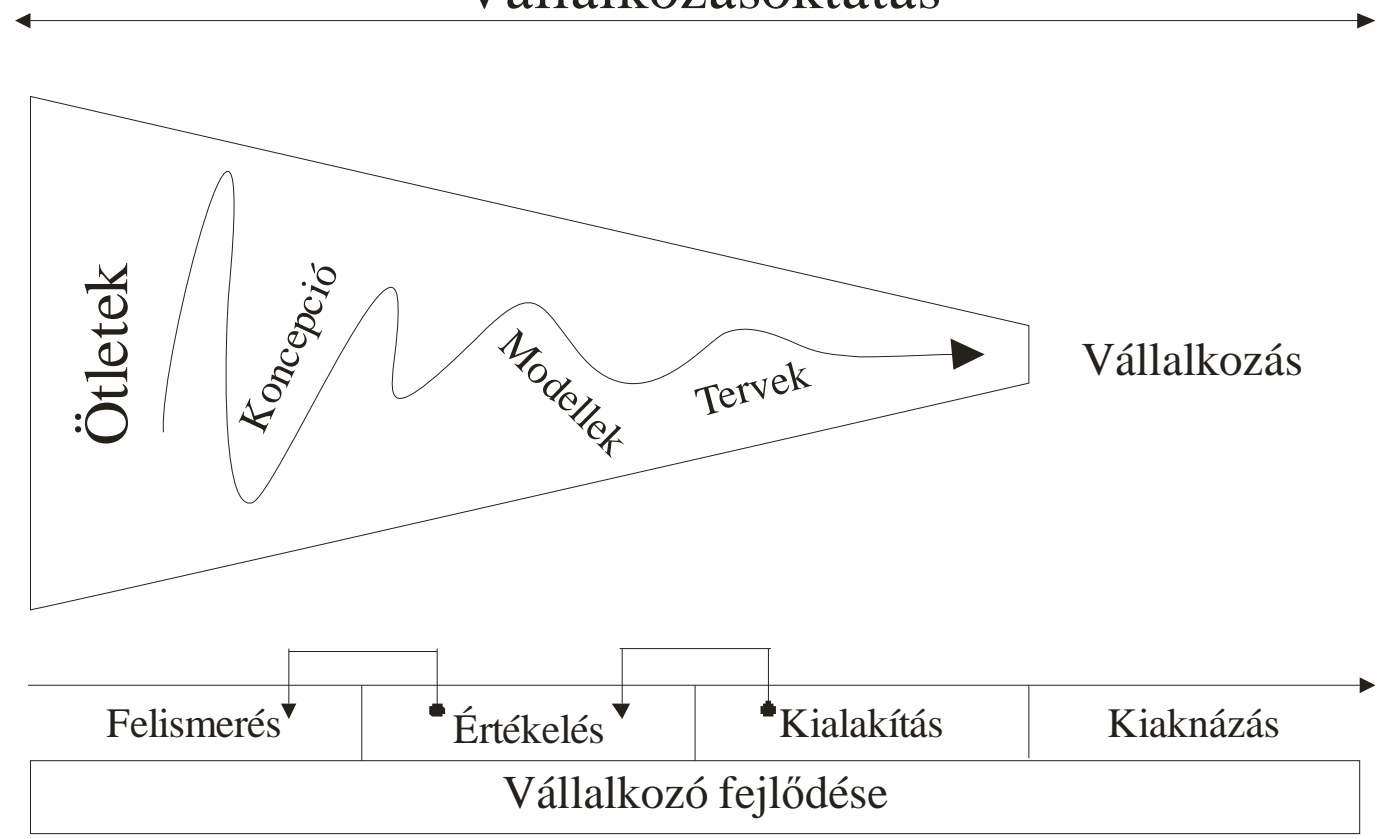

Forrás: Lourenco (2013), 509. o. alapján saját szerkesztés

A vállalkozói folyamat során mindvégig jelenlévő ötlet különösen fontos a vállalkozói viselkedések, tulajdonságok és készségek fejlesztése során a folyamat minden egyes fázisában (a tudatosság kiépítésétől az indulás utáni fázisig). 
Összességében, a vállalkozói folyamat kezdeti szakasza divergens fázison halad át, mely során ötletek széles skálája merül fel és később az ötletek üzleti koncepciókká, üzleti modellekké, üzleti tervekké és induló vállalkozásokká formálódnak a lehetőség fejlesztési folyamaton keresztül (Lourenco 2013).

A 2007-ben a fent bemutatott modell keretrendszerként szolgált egy három éves kurzussorozat, az Ideas, Creativity and Entrepreneurship (ICE) (Ötletek, kreativitás és vállalkozás) megtervezésében, melynek célja:

- vállalkozói viselkedések, tulajdonságok és készségek fejlesztése;

- karrierrel kapcsolatos kilátások és választások segítése;

- üzleti ötletek portfolió kidolgozásának elősegítése;

- a hallgatók eligazítása és segítése a teljes vállalkozói folyamat elsajátításában; valamint

- a hallgatók számára olyan játékos és konstruktív környezet biztosítása, ahol különböző eszközöket használnak, illetve ismeretanyagot és projekteket mutatnak be.

Az ICE első évének feladatai a vállalkozói karrierutak megismertetése, a lehetőség felismerési folyamat elősegítése, valamint a vállalkozói viselkedések, tulajdonságok és készségek fejlesztése. A fejlesztendő kompetenciák közül az alábbiakat emeli ki: kreatív gondolkodás, kommunikáció, problémamegoldás, döntéshozatal, autonómia, lehetőség keresés és önbizalom. Az eszközöket és módszereket workshopok segítségével mutatják be a hallgatóknak, így cselekvés útján tanulnak, amely hozzájárul a lehetőségek felismerésének és a lehetőség fejlesztésének folyamatához.

A második év legfontosabb célja a lehetőségek értékelése és működtetése. Emellett további célként jelenik meg a készségek, mint például a csapatmunka, tárgyalás, kapcsolati háló kiépítése, vezetőképesség, kommunikáció, kritikai gondolkodás és értékelés, problémamegoldás, tervezés, döntéshozatal, autonómia, teljesítményorientáltság, empátia és önbizalom fejlesztése. Ahogy az első. évben is, az eszközöket és módszereket workshopok segítségével mutatják be a hallgatóknak, így cselekvés útján tanulnak, amely hozzájárul az üzleti lehetőségek szürésének és érvényesítésének folyamatához (megvalósíthatósági elemzés), valamint az üzleti terv kidolgozásához. A módszerek alkalmazásának célja minden munkafolyamatban a kreativitás (a divergens folyamatok elősegítése) és a logikus 
gondolkodás (a konvergens folyamatok elősegítése) ösztönzése, illetve a vállalkozói viselkedés fokozatos kialakulása (Lourenco és Jayawarna, 2011).

A harmadik év feladatai az üzlet létrehozásának és a lehetőségek kiaknázásának elősegítése. A hallgatóknak az üzleti elképzelésüket valóban ki kell próbálniuk, mégpedig úgy, hogy vállalkozást alapítanak és müködtetnek hat hónapon keresztül. Ennek célja az, hogy a hallgatók megtapasztalhassák az üzleti lehetőség kiaknázásának folyamatát és megértsék a „,vállalkozás világát”. További cél azon vállalkozói viselkedések, tulajdonságok és készségek fejlesztése, melyeket csak egy valódi vállalkozás elindítása és müködtetése során lehet elsajátítani, ilyen például: rugalmasság a kihívások kezelésében, a bizonytalanság kezelése és élvezése, kockázattürés, kockázatvállalás bizonytalan környezetben, sokoldalúság és dinamizmus. Ezen időszakban a hallgatók munkalehetőséget kapnak az egyetem üzleti inkubátorában, az Innospace-ben. Így a hallgatókat jövőbeni vállalkozókként kezelik, akik hasonló gondolkodású, hasonló folyamaton áteső egyének mellett dolgozhatnak.

8. táblázat: Pedagógiai módszerek az egyes szintek esetében

\begin{tabular}{|l|l|}
\hline \multicolumn{1}{|c|}{ Szint } & \multicolumn{1}{|c|}{ Pedagógiai módszerek } \\
\hline 1. év & $\begin{array}{l}\text { Kreativitási tevékenységek; problémaalapú tevékenységek; szituációs } \\
\text { gyakorlatok; szerepjátékok; önértékelési eszközök; videós esettanulmányok; } \\
\text { animációk, történetek, analógiák, metaforák és klipek a BBC Dragon’s Den } \\
\text { (Sárkánybarlang) címü músorából az elméletek illusztrálására; prezentációk; } \\
\text { portfolió elkészítése és bemutatása }\end{array}$ \\
\hline 2. év & Az 1. év feladatai, továbbá megvalósíthatósági elemzés és üzleti terv írása \\
\hline 3. év & $\begin{array}{l}\text { Az inkubációs központban történő regisztráció és munka valódi jövőbeni } \\
\text { vállalkozókkal; üzleti terv elkészítése; üzletindítási esemény; az üzleti terv } \\
\text { Dragon's Den típusú prezentálása (valódi üzleti sárkányokkal); vállalkozásindítás } \\
\text { és -menedzsment; végsó üzleti terv és beszámoló készítése; online reflektív } \\
\text { tanulási napló (amely számos tanulási szempontot lefed); üzleti mentorok a } \\
\text { folyamat elősegítésében }\end{array}$ \\
\hline $\begin{array}{l}\text { Tanterven kívüli } \\
\text { tevékenységek }\end{array}$ & $\begin{array}{l}\text { Például: hallgatói vállalkozó társaság, munka az Innospace üzleti inkubátorban, } \\
\text { munka az alábbiak keretében: az egyetem vállalkozási bajnoka, Diplomás } \\
\text { Vállalkozók Nemzeti Tanácsa, Shell Livewire, Shell Technológiai Vállalkozási } \\
\text { Program, Make your Mark kezdeményezések, Young Enterprise program, } \\
\text { Innoflux, Flux500, iskolákban tartott vállalkozási napok, Innospace üzleti terv } \\
\text { verseny, Xing Business Game, stb. }\end{array}$ \\
\hline
\end{tabular}

Forrás: Lourenco (2013), 510. o. alapján saját szerkesztés

A hagyományos módszerek, mint például az esszék, vizsgák és beszámolók, kevésbé hatékonyak, amikor a tanulási eredmények viselkedésre vagy hozzáállásra irányulnak (Pittaway et al. 2009). 
Ahogy azt a szakirodalom is hangsúlyozza, szükség van a karok közötti együttmüködésre, amennyiben a cél a diplomás vállalkozások számának növelése és a vállalkozók fejlesztése. A gyakorlatban azonban az üzleti iskoláknak jelentős kihívásokkal kell szembenézniük, mivel egyedi és releváns programok létrehozása jelentős mennyiségű erőforrást, időt és együttműködést igényel a különböző karok tagjai között (Gibb, 2011). Lourenco (2013) szeint ez a probléma azzal hidalható át, hogy az üzleti iskola olyan szabványosított csomagot kínál a többi karnak, amely a teljes képzési anyag 80\%-át képviseli. Ez a csomag tartalmazza a vállalkozás kulcsfontosságú tényezőihez kapcsolódó anyagot, amely más tantárgyakba is átvihető - például a vállalkozás elindításának folyamata, a vállalkozás koncepciója, a lehetőség beazonosítása, kreativitás és innováció, marketing, üzleti terv, kisvállalkozás menedzsment, üzleti terv prezentációja és kutatási módszerek. Továbbá képzési anyagot is tartalmaz, úgy mint irányelvek, tevékenységi minták, PowerPoint diák, értékelési és feladatminták. A képzési anyag maradék 20\%-a szabadon kidolgozható a nem üzleti oktatók által, így a tantárgynak megfelelően specifikussá tehető a teljes csomag (9. táblázat).

9. táblázat: Pedagógia, mintaterv és tervező

\begin{tabular}{|l|l|l|}
\hline \multicolumn{1}{|c|}{ Pedagógiai példa } & \multicolumn{1}{|c|}{ Mintaterv } & \multicolumn{1}{c|}{ Tervezó } \\
\hline $\begin{array}{l}\text { Minielöadás; elmélet, } \\
\text { eszköz, koncepció vagy } \\
\text { módszer bemutatása }\end{array}$ & Szabványosított tananyag & Üzleti iskola \\
\hline $\begin{array}{l}\text { Esetpélda, forgatókönyv } \\
\text { vagy történet }\end{array}$ & Rugalmas tananyag & Nem üzleti iskola \\
\hline Tevékenység & $\begin{array}{l}\text { Szabványosított formátum } \\
\text { változtatható } \\
\text { tartalommal/kontextussal }\end{array}$ & Üzleti/nem üzleti \\
\hline Beadandó feladat & $\begin{array}{l}\text { Szabványosított formátum } \\
\text { változtatható } \\
\text { tartalommal/kontextussal }\end{array}$ & Üzleti/nem üzleti \\
\hline Értékelés & $\begin{array}{l}\text { Szabványosított formátum } \\
\text { változtatható } \\
\text { tartalommal/kontextussal }\end{array}$ & Üzleti/nem üzleti \\
\hline
\end{tabular}

Forrás: Lourenco (2013), 514. o. alapján saját szerkesztés

Az üzleti iskola felelős az oktatók képzéséért, melynek célja a nem üzleti oktatók segítése a tananyag (80\%) használatának és a fennmaradó képzési tananyag (20\%) megtervezésének elsajátításában. Ez tartalmazza: esettanulmányok készítése, videók, vendég előadók, valamint irányelvek, képzési tevékenységek, PowerPoint diák, valamint értékelési és feladatminták módosítása a különböző tantárgyaknak történő megfelelés érdekében. 


\subsection{Oktatási koncepcionális modell}

Az oktatástudományi szakirodalomra építve Bechard és Gregoire (2005) különböző vállalkozásoktatási modelleket javasoltak és vázoltak fel. Az „oktatási modell” (teaching modell) jól ismert fogalom az oktatástudományban, viszont ritkán használatos a vállalkozástudomány területén, ahol nincs általános keretrendszer, vagy egyezményes jó gyakorlat az oktatás mikéntjét illetően. Legendre a következőképpen határozza meg az oktatási modellt: „egy bizonyos típusú környezet ábrázolása, melynek célja meghatározott célok és célkitüzések elérésére irányuló pedagógiai helyzet megoldása, amely magában foglalja az azt igazoló és példaszerü jelleget adó elméleti keretrendszert is” (Bechard Gregoire, 2005, 107.o.). A szerzők szerint „az oktatási modellek relevanciája az, hogy a fogalom a tudományos szakemberek és oktatók oktatásról és saját tényleges oktatói magatartásukról alkotott koncepciókat összekötő kapocsra koncentrál” (Bechard - Gregoire, 2005, 108.o.).

Fayolle és Gailly (2008) kidolgozott egy koncepcionális modellt a vállalkozásoktatásban. Az oktatási modell ontológiai szintje két dimenziót foglal magában (16. ábra):

- egyrészt világosan meg kell határozni, mit takar (és mit nem takar) a vállalkozás mint oktatási terület,

- másrészt pedig meg kell határozni, mire utal az „oktatás” az oktatók és hallgatók számára a vállalkozás kontextusában.

Az ontológiai szint a következő kérdésekre fókuszál:

1. Mit jelent a vállalkozásoktatás?

2. Mit jelent az oktatás a vállalkozás kontextusában?

3. Mi az oktató szerepe és mi a résztvevők szerepe?

Számos definíció létezik a mind vállalkozó, mind a vállalkozásoktatás fogalmáról attól függően, hogy milyen aspektusból vizsgálják. Éppen ezért kiindulásként minden esetben szükséges egy definíció kiválasztása, amely mentén kijelöljük vizsgálódásunk legföbb határvonalait. 
16. ábra: Oktatási koncepcionális modell vállalkozásoktatás részére

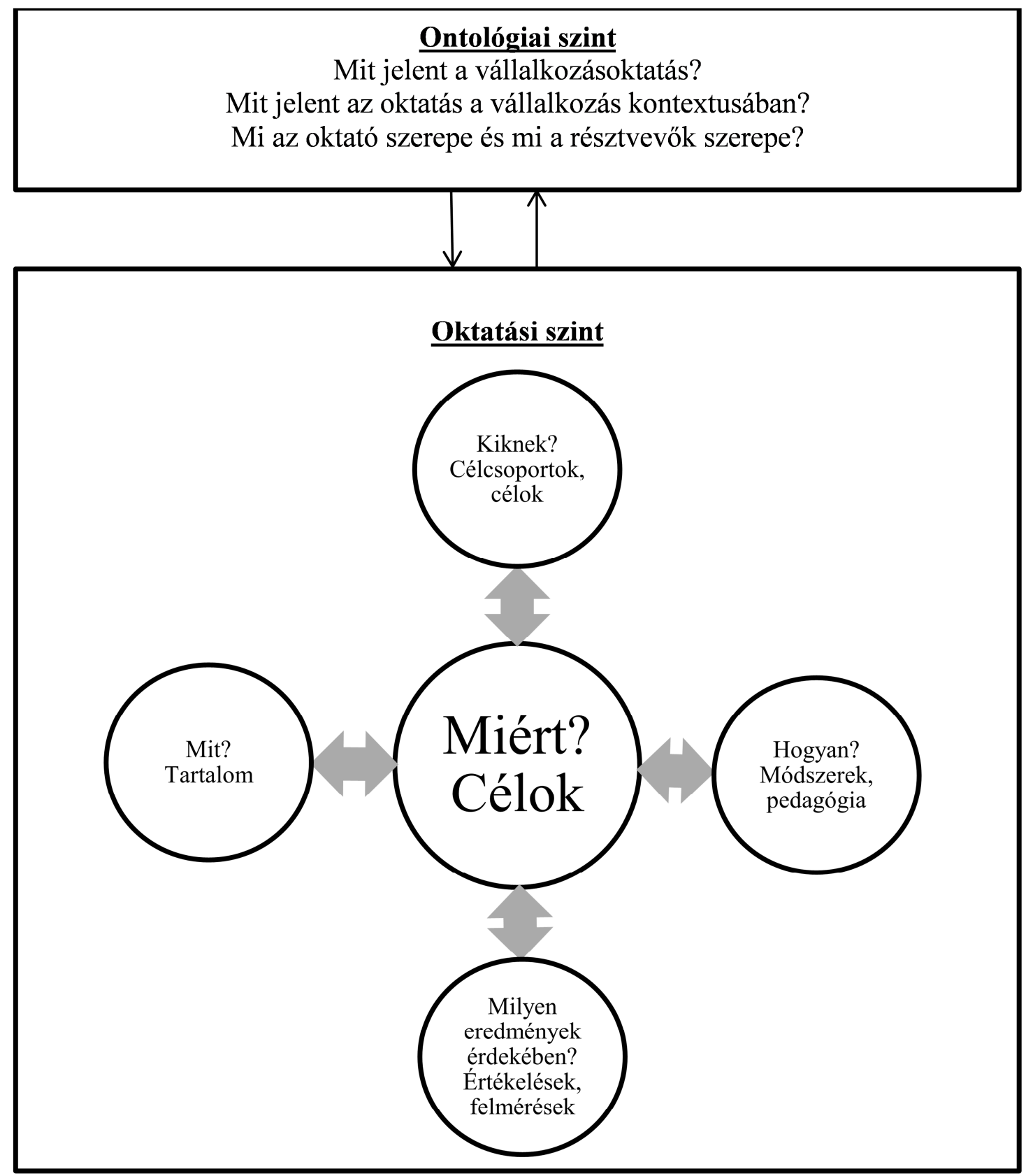

Forrás: Fayolle-Gailly 2008, 572.o.alapján saját szerkesztés

A vállalkozásoktatás „oktatási modelljének” oktatási szintje esetében a vállalkozásoktatás a célközönség, célok, tartalmak és pedagógiai módszerek széles skáláját fedi le. Ebben az értelemben az oktatási szint az oktatási program öt meghatározott, összefüggésben álló kérdés köré épülő tervezetére és felépítésére vonatkozik, melyekkel a következő sorrendben ajánlott foglalkozni: miért? kiknek? milyen eredmények érdekében? mit? hogyan? (10. táblázat). 
10. táblázat: Oktatási szint tartalma

\begin{tabular}{|c|c|}
\hline Kérdés & Tartalom \\
\hline 1. Miért (célok)? & $\begin{array}{l}\text { - A vállalkozásoktatás céljai a tanuláshoz és a társadalmi igényekhez } \\
\text { kell, hogy kapcsolódjon. } \\
\text { - A tanulási célok a személyes fejlődésre, a tudatosságra és a } \\
\text { gondolkodásmódra vagy kultúrára vonatkozhatnak. } \\
\text { - A vállalkozás lehetővé teszi az egyének számára tehetségük és } \\
\text { kreativitásuk fejlesztését, álmaik elérését, nagyobb függetlenség } \\
\text { elérését és bizonyos szabadságérzetet. } \\
\text { - A vállalkozónak, a vállalkozói folyamat központi elemeként, } \\
\text { állandóan a lehetőségeket kell kutatnia a megfelelő erőforrások } \\
\text { szervezésére és felhasználására annak érdekében, hogy a } \\
\text { lehetőségeket gazdasági vagy társadalmi tevékenységekké } \\
\text { alakíthassa. Ennek során a vállalkozó müködésbe hozza a ,kreatív } \\
\text { rombolás” folyamatot, kölcsönvéve Schumpeter elképzelését: olyan } \\
\text { vállalkozást hoz létre, amely innovációkat állít elö, amely aztán a } \\
\text { meglévő vállalatokat alkalmazkodásra vagy eltünésre kényszeríti. }\end{array}$ \\
\hline $\begin{array}{l}\text { 2. Kiknek (célpont, } \\
\text { célközönség)? }\end{array}$ & $\begin{array}{l}\text { - Jelentös különbségek vannak a diplomás közgazdász hallgatóknak, a } \\
\text { tudományos, múszaki vagy irodalmi hallgatóknak, illetve a } \\
\text { tanároknak és PhD hallgatóknak szánt kurzusok között. } \\
\text { - A vállalkozásoktatási programok változatos célcsoportjai tehát } \\
\text { különböző demográfiai jellemzökkel, valamint a vállalkozói } \\
\text { folyamatban különböző szintü részvételi szándékkal és ambíciókkal } \\
\text { rendelkező hallgatókból áll. }\end{array}$ \\
\hline $\begin{array}{l}\text { 3. Milyen } \\
\text { eredmények } \\
\text { érdekében } \\
\text { (értékelések, } \\
\text { felmérések)? }\end{array}$ & $\begin{array}{l}\text { - Az oktatási program megszületésével egy időben ki kell dolgozni az } \\
\text { értékelést is. } \\
\text { - Az értékelés tehát a keretrendszer kulcsfontosságú dimenziója, mely } \\
\text { ugyanolyan jelentőséggel bír, mint a többi dimenzió. }\end{array}$ \\
\hline $\begin{array}{l}\text { 4. Mit (tartalom, } \\
\text { elméletek)? }\end{array}$ & $\begin{array}{l}\text { - Három fö dimenziót különböztethetünk meg, melyek a } \\
\text { vállalkozásoktatás tartalmának irányát és szerkezetét befolyásolják: } \\
\text { a) a szakmai dimenzió, } \\
\text { b) a szellemi dimenzió és } \\
\text { c) az elméleti dimenzió. } \\
\text { - A vállalkozásoktatás szakmai dimenziója föként a gyakorlati tudással } \\
\text { vagy know-how-val kapcsolatos, és kisebb mértékben az elméleti } \\
\text { tudással. Ez a dimenzió konkrétan három ismeretfajtára épít: know- } \\
\text { what, know-how, konow-who }{ }^{4} \text {. }\end{array}$ \\
\hline $\begin{array}{l}\text { 5. Hogyan } \\
\text { (módszerek, } \\
\text { pedagógiák)? }\end{array}$ & $\begin{array}{l}\text { - A vállalkozásoktatási programban használt oktatási módszerek a } \\
\text { keretrendszer „hogyan” kérdéséhez kapcsolódnak. A pedagógia nem } \\
\text { önmagában egy cél. A pedagógia egy eszköz a célok eléréséhez. } \\
\text { - Amint a célok megegyezésre és a konkrét korlátok beazonosításra }\end{array}$ \\
\hline
\end{tabular}

\footnotetext{
${ }^{4}$ Know-what: mit kell tenni egy adott szituációban a döntéshozás és a cselekvés érdekében. Például, mit kell tenni egy technológiai vállalat létrehozása, egy lehetőség érvényesítése, egy piackutatás lebonyolítása, stb. érdekében. Know-how: hogyan kell megoldani egy adott szituációt. Például, hogyan kell egy adott projekt és egy személyes profil közötti megfelelést ellenőrizni a felhalmozott tapasztalatot figyelembe véve, hogyan kell felismerni és kezelni a kockázatokat, stb. Know-who: kik tekinthetők hasznosnak és melyek a hasznos hálózatok egy adott környezetben. Például, beazonosítani egy új vállalkozás létrehozásának általános szereplőit a biotechnológia szektorban, meghatározni egy projekt potenciális érdekeltjeit, érintettjeit, beazonosítani a releváns tőkeképviseleteket és üzleti angyalokat, stb.
} 


\begin{tabular}{|l|l|}
\hline & kerülnek, ki lehet választani a megfelelő oktatási módszereket. \\
- A vállalkozásoktatás területén a tesztelt és alkalmazott pedagógiai \\
módszerek, megközelítések és útmutatók széles skálája megtalálható. \\
Ezek között szerepel a valóságos vagy virtuális esetek, szerepjátékok \\
és problémák alkalmazása. Ezeket például üzleti tervek kidolgozása \\
vagy értékelése, új vállalkozás létrehozására irányuló projekt, illetve \\
viselkedési gyakorlatok és számítógépes szimulációk során lehet \\
használni. Hagyományos vagy interaktív módszereket is tartalmazhat, \\
csakúgy mint interjúk vállalkozókkal, illetve iránymutatás és \\
tanácsadás fiatal vállalkozók számára.
\end{tabular}

Forrás: Fayolle-Gailly (2008) alapján saját szerkesztés

A szerzők a modellhez kapcsolódóan a következő javaslatokat fogalmazták meg FayolleGailly (2008):

1. Minden egyes vállalkozásoktatási program a vállalkozás egyértelmü koncepciójára kell, hogy épüljön, így a vállalkozásoktatás definíciója sem lesz többértelmű.

2. Minden egyes vállalkozásoktatási kurzus esetén az oktatónak, illetve a tanárnak tisztáznia kell álláspontját az oktatás főbb koncepciót illetően, a tanár szerepét, valamint a hallgatók vagy résztvevők szerepét.

3. A vállalkozásoktatási kurzusnak egyértelmü és érthető célokat kell megcéloznia mikro (egyén, résztvevő) szinten és makro (szervezet, társadalom) szinten.

4. A vállalkozásoktatási kurzust a célcsoport profiljának és hátterének alapos ismeretében kell megtervezni, különösképpen az előzetes vállalkozási tapasztalatokat illetően.

5. A célokkal és a célcsoport jellemzőivel összhangban, a vonatkozó értékelési kritériumokat, valamint azok hatékony mérési módszereit minden egyes vállalkozásoktatási kurzus esetén meg kell határozni.

6. A céloktól és a célcsoport profiljától függően minden vállalkozási kurzus tartalmát egyértelműen meg kell határozni a három dimenzió kombinálásának megfelelően (szakmai, szellemi és elméleti).

7. Minden vállalkozásoktatási kurzus esetében a pedagógiai módszereket a céloknak, a célközönség jellemzőinek, a tartalomnak és az intézményi környezetből fakadó korlátoknak való megfelelésük és az előzetes hatékonyságuk alapján kell kiválasztani.

A korlátokat figyelembe véve, az előző részben bemutatott egyes ontológiai és oktatási dimenziók esetében hozott különböző döntések eltérő tanulási folyamatokat eredményeznek. Ezen folyamatokat legalább három fő kategóriába lehet sorolni (11. táblázat). 
11. táblázat: A vállalkozásoktatás tanulási folyamatainak fő dimenziói és fogalmai

\begin{tabular}{|c|c|c|}
\hline Tanulási folyamat & Oktatási modell fő dimenziói & $\begin{array}{l}\text { Vonatkozó fogalmak és } \\
\text { elméletek }\end{array}$ \\
\hline $\begin{array}{l}\text { A tanulás célja a vállalkozó } \\
\text { egyénné válás }\end{array}$ & $\begin{array}{l}\text { A vállalkozás mint általános } \\
\text { fogalom } \\
\text { Szellemi dimenzió } \\
\text { hangsúlyozása (know-why és } \\
\text { know-when) } \\
\text { A vállalkozáshoz való } \\
\text { hozzáállásban, felfogásban és } \\
\text { szándékban várt változás } \\
\text { Célközönség nagyfokú } \\
\text { diverzitása: hallgatók az üzleti } \\
\text { és nem üzleti területről } \\
\text { A vállalkozók mint példaképek } \\
\text { jelentősége a tanteremben }\end{array}$ & $\begin{array}{l}\text { Vállalkozói szándék } \\
\text { Vállalkozói esemény } \\
\text { Tervezett viselkedés elmélete } \\
\text { Vállalkozói önhatékonyság } \\
\text { Vállalkozói beállítottság } \\
\text { (egyéni szinten alkalmazva) }\end{array}$ \\
\hline $\begin{array}{l}\text { A tanulás célja a vállalkozóvá } \\
\text { válás }\end{array}$ & $\begin{array}{l}\text { A vállalkozás mint konkrét } \\
\text { fogalom és szakmai helyzet } \\
\text { (önálló vállalkozás, vállalati } \\
\text { vállalkozás, stb.) } \\
\text { Középpontban a } \\
\text { szakmai/gyakorlati dimenzió } \\
\text { van (know-what, know-how és } \\
\text { know-who) } \\
\text { Cselekvés útján történő tanulás } \\
\text { Elvárt eredmény a készségek, } \\
\text { gyakorlati ismeretek, technikák } \\
\text { elsajátítása a tevékeny és } \\
\text { sikeres vállalkozóvá váláshoz } \\
\text { Elvárt eredmény a vállalkozói } \\
\text { kompetenciák fejlesztése } \\
\text { A fó célközönség a vállalkozók, } \\
\text { akik valódi, konkrét vállalkozói } \\
\text { projektek keretében } \\
\text { tevékenykednek }\end{array}$ & $\begin{array}{l}\text { Vállalkozói folyamat elméletek } \\
\text { Próbálkozás/kialakulás útján } \\
\text { történő tanulás } \\
\text { Tanulás a kudarcból } \\
\text { Korlátozott racionalitás } \\
\text { Kivitelezés } \\
\text { Vállalkozói gondolkodás } \\
\text { (heurisztika, kockázatészlelés, } \\
\text { stb.) } \\
\text { Vállalkozói menedzsment és } \\
\text { növekedés }\end{array}$ \\
\hline $\begin{array}{l}\text { A tanulás célja elméleti } \\
\text { szakemberré válás }\end{array}$ & $\begin{array}{l}\text { A vállalkozás tudományos } \\
\text { fogalma } \\
\text { Az elméleti dimenzión van a } \\
\text { hangsúly } \\
\text { Didaktikus oktatási modell } \\
\text { Kutatási kérdések megbeszélése } \\
\text { a tanteremben } \\
\text { Fő célközönség: PhD hallgatók, } \\
\text { oktatók és kutatók } \\
\text { Elvárt eredmény az elméleti és } \\
\text { tudományos ismeretek } \\
\text { elsajátítása }\end{array}$ & $\begin{array}{l}\text { Vállalkozás mint kutatási terület } \\
\text { Elméletek a terület oktatására és } \\
\text { kutatására }\end{array}$ \\
\hline
\end{tabular}

Forrás: Fayolle (2008), 581 o. alapján saját szerkesztés 


\subsection{Urbana Champaign-i Illinoisi Egyetem (UIUC) modellje}

A továbbiakban az Urbana Champaign-i Illinoisi Egyetemen (University of Illinois at Urbana Champaign UIUC) kialakított keretrendszert mutatom be, amely elsősorban a vállalkozói szemléletmód egész egyetemen történő kialakítását célozza meg. 2003-ban a Ewing Marion Kauffman Alapítvány felkérést adott ki olyan javaslatok előterjesztésre, melyek az egyetemeken átnyúló vállalkozásoktatás kialakításának támogatási lehetőségeiről szólnak az amerikai föiskolákon és egyetemeken. Az UIUC egyike volt a Kauffman Alapítvány díjnyerteseinek és javaslatában a tanári karral, a diplomás hallgatókkal valamint a diploma előtt állókkal való együttműködést is szorgalmazza (Mendes-Kehoe 2009).

Az Illinoisi Egyetemet 1867-ben szövetségi támogatással alapították, amelybe 43000 hallgató iratkozott be, akik közül kb. 11000 diplomás és továbbképzésben részt vevő hallgató. Továbbá közel 3000 fôs oktatói kar és 8000 adminisztratív és szakmai/támogató személyzet áll rendelkezésre. Az egyetem egyik legnagyobb erőssége a kutatás, amit jól mutat, hogy több mint 500 millió dollárnyi éves kiadást fordítanak K+F-re, ezzel felkerülve az amerikai kutatóegyetemek top 20-as listájára (Mendes-Kehoe 2009).

A keretrendszer kidolgozása során első fontos lépés a diagnózis, mellyel a megcélzott „vásárlók” heterogén igényeit, jellemzőit és elvárásait azonosítják be. A következő lépések sikeres megvalósítása érdekében a „4-D” keretrendszert alkalmazták a UIUC vállalkozói orientációjának átalakításához: diagnosztizál (diagnose), tervez (design), teljesít (deliver) és meghatároz (determine). Ezen összetevők szorosan összefüggnek egy dinamikus folyamatban, valamint a stratégiai következetesség és a környezetre történő reagálás során szükséges változtatások megvalósítására használatosak.

A diagnosztikai összetevők között szerepelt:

- adminisztrátor stakeholder interjúk;

- oktatói kar igényfelmérése;

- oktatói pályafutás alakulásának tanulmányozása;

- diplomás hallgatók felmérése;

- elsőévesek felmérése; és

- vállalkozói érdekek, tevékenységek leltározása az oktatói karon belül. 
A 17. ábra felvázolja a Vállalkozói Akadémia (mint egy elkülönült egység) módszerét az egyetemen megvalósuló program létrehozásában. Az ábra jobb oldala a stratégia kialakításától a stratégia megvalósítása felé tartó áramlást mutatja. A baloldal pedig jelzi a 4-D modell megfelelő szakaszát. A 4-D egy dinamikus folyamatot képez, melyen keresztül felismerik a vállalkozói igényeket, biztosítják a vállalkozásoktatást, finanszírozzák a vállalkozástudományhoz kapcsolódó tevékenységeket, és folyamatosan ösztönzik a vállalkozástudatot. Ez a két rész nem egymástól független. A stratégiai tervek kialakítása a diagnózis fázisából ered, és a stratégiai tervek módosítása a meghatározási, illetve értékelési, szakasznak megfelelően történik.

17. ábra: 4-D stratégiai menedzsment keretrendszer

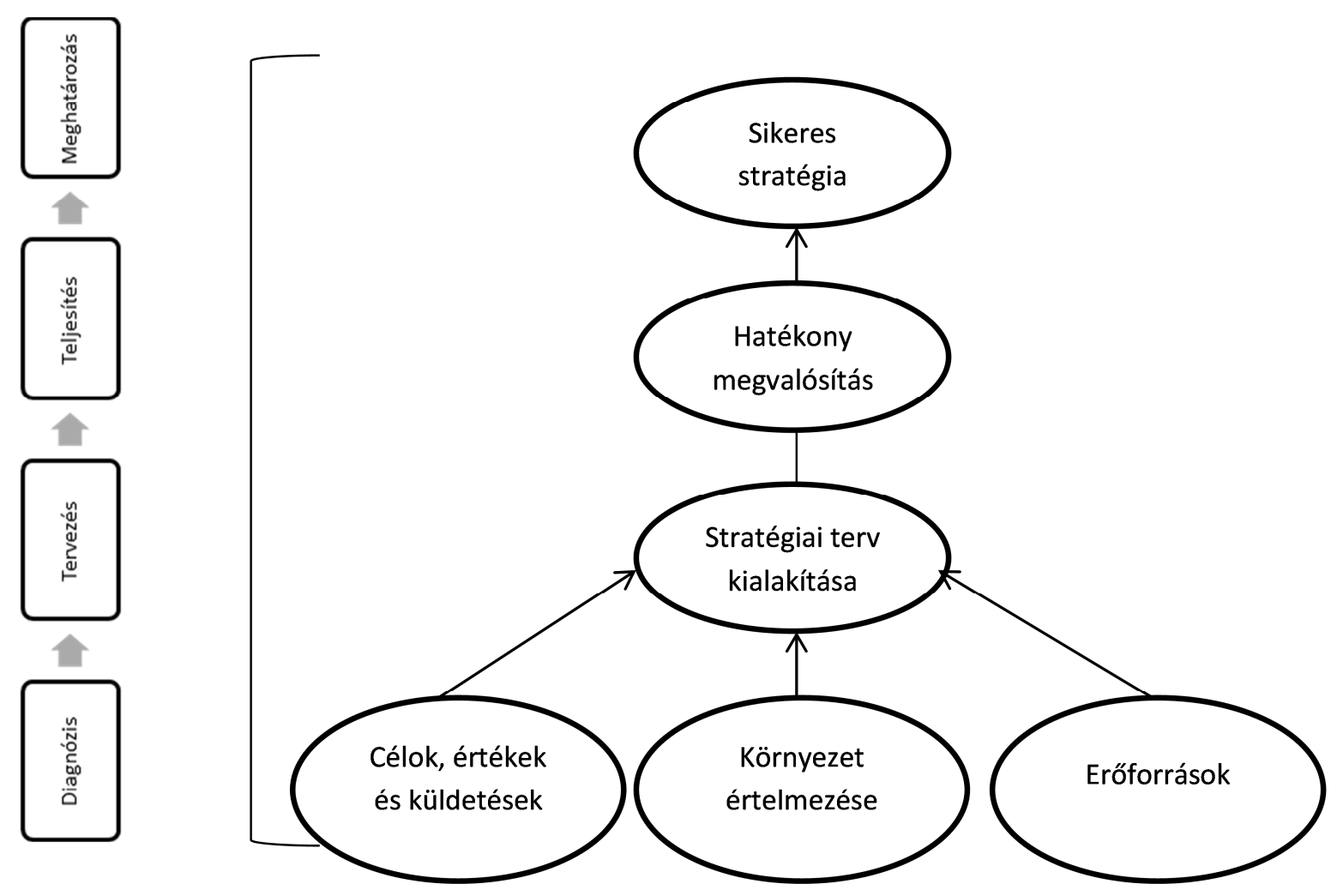

Forrás: Mendes-Kehoe (2009), 89. o. alapján saját szerkesztés

Ahhoz, hogy az Akadémia erőfeszítései a teljes egyetem vállalkozási kultúrájának átalakításában sikeresek legyenek, nélkülözhetetlen a stratégiai folyamat. A 15. ábrán bemutatott 4-D modell az Akadémia erőfeszítéseinek egyik megnyilvánulása arra, hogy integrálja stratégiai terveinek kialakítását és megvalósítását. Az ábra jobb oldalán a sikeres stratégiákban fellelhető közös elemek általános bemutatása. A következetes és hosszú távú célok és küldetés iránymutatók a szervezet tevékenységei számára. A baloldal mutatja be az 
Akadémia erőfeszítéseit a 4-D modell bevezetésében a jobb oldali általános modellnek megfelelően.

12. táblázat: A stratégiai tervektől a stratégiai célokig

\begin{tabular}{|c|c|}
\hline Stratégiai & Célok \\
\hline $\begin{array}{l}\text { A vállalkozástudomány mint } \\
\text { elismert tanulmányterület } \\
\text { erősítése }\end{array}$ & $\begin{array}{l}\text { - Mentorhálózatok létrehozása az oktatók és a hallgatók számára } \\
\text { - Oktatók beazonosítása és gondozása } \\
\text { - A tudományterületeken és szakterületeken átnyúló hálózatépítés } \\
\text { elősegítése } \\
\text { - Oktatók támogatása a tantervi és tanterven kívüli tevékenységek } \\
\text { kialakításában } \\
\text { - Oktatók és diplomás hallgatók támogatása a } \\
\text { vállalkozástudományt tanulók és oktatók országos közösségében } \\
\text { való részvételben } \\
\text { - Programok létrehozása, melyek támogatják az oktatók és } \\
\text { hallgatók által végzett vállalkozástudományi kutatásokat }\end{array}$ \\
\hline $\begin{array}{l}\text { Helyi, nemzeti és } \\
\text { nemzetközi identitás } \\
\text { kialakítása az Akadémia } \\
\text { számára }\end{array}$ & $\begin{array}{l}\text { - A vállalkozástudomány értelmezésének és elismerésének } \\
\text { szélesítése az UIUC kampuszon } \\
\text { - Legjobb gyakorlatok/modellek megismertetése és terjesztése } \\
\text { - Egyetemekkel és más nemzeti szervezetekkel történő } \\
\text { együttmüködés a tudatosítás és legjobb gyakorlatok kibővítése } \\
\text { érdekében } \\
\text { - Vállalkozástudományi vállalkozások létrehozásának elősegítése, } \\
\text { akár társadalmi, gazdasági, szellemi vagy kulturális, a UIUC } \\
\text { közösségben } \\
\text { - Különböző publikációk készítése a vállalkozói tevékenységek és } \\
\text { lehetőségek kiemelésére az UIUC kampuszán }\end{array}$ \\
\hline $\begin{array}{l}\text { Vállalkozói készségek } \\
\text { fejlesztése }\end{array}$ & $\begin{array}{l}\text { - Tudatosság növelése a pályafutás vállalkozóibb szellemben } \\
\text { történő irányításának módjában } \\
\text { - Vállalkozói felfogás bővítése az adminisztrátorok körében }\end{array}$ \\
\hline $\begin{array}{l}\text { Vállalkozástudományi } \\
\text { mesterek beazonosítása }\end{array}$ & $\begin{array}{l}\text { - Oktatók beazonosítása és gondozása } \\
\text { - Mesterek beazonosítása és gondozása az adminisztrátorok és más } \\
\text { tudományos szakemberek körében }\end{array}$ \\
\hline $\begin{array}{l}\text { Fenntarthatóság létrehozása } \\
\text { az Akadémia számára }\end{array}$ & $\begin{array}{l}\text { - Minimum } 10 \text { millió dollárnyi adomány összegyüjtése } \\
\text { - Állami forrásokból származó finanszírozási lehetőségek } \\
\text { felismerése és biztosítása az Akadémia számára } \\
\text { - Különböző helyi, állami és nemzeti szervezetektől származó } \\
\text { támogatások biztosítása }\end{array}$ \\
\hline
\end{tabular}

Forrás: Mendes-Kehoe (2009), 91. o. alapján saját szerkesztés

Az Akadémia megvizsgálta a Campus különböző alkotóelemeit a vállalkozásoktatásról alkotott felfogásuk, abban való részvételük és azzal szemben támasztott elvárásaik, valamint egyetemi tevékenységeik tekintetében. A diagnosztikai lépések a program azon összetevőinek megerősítésére szolgáltak, melyeket a Kauffman Alapítványnak tett kezdeti javaslat létrehozása során alakítottak ki, és addig nem látható lehetőségeket hoztak felszínre. Emellett 
segítséget nyújtott az újrarangsorolásban, a konkrétabb célok és megközelítések kidolgozásában és a stratégiai terv kialakításában. A 4-D keretrendszere biztosítja a terv felvázolásához és megvalósításához, majd később az értékeléshez és esetleges módosításokhoz szükséges folyamatot.

A stratégiai terv kialakítása során az oktatói és adminisztrációs tanulmányok a Campus különböző területeiről származó nézőpontokat gyüjtötték össze, értékes információkat nyújtva az Akadémia számára a felépítését és szervezetét, a megfelelő döntéshozói eljárást, a javasolt tevékenységeket, illetve az Akadémia által kínálásra szánt programok tartalmát illetően.

A diagnosztikai lépések eredményeit az Akadémia céljaiként értelmezték újra. A 12. táblázat mutatja a diagnózis szakaszában azonosított vállalkozástudományi igényeket, valamint azon programokat és projekteket, melyeket az Akadémia tervezett az igényekre reagálva.

A megtervezett program megvalósítása alkotja a teljesítés fázisát, melyhez az Akadémia funkcionális stratégiák körét tervezte meg, többek között marketing és müködtetés. Mivel módszerét tekintve meglehetősen új, ezért az Akadémiának az önfenntartást és a vállalkozói hozzáállást aktívan támogatnia kell.

A teljesítés fázisában az Akadémia visszacsatolásokat gyüjt a meghatározási szakaszban következő értékelésekhez. Az általános értékelési kritériumokat a stakeholderek javasolták a diagnózis folyamata során, konkrétabb kritériumokat is meghatároznak az egyes eseményekhez vagy eseménytípusokhoz. 


\subsection{OECD keretrendszer}

Ahogy a fentebbiekből is kiderül, a vállalkozó egyetem definíciója, eszközrendszere, oktatási metodikája eltérően jelenik meg a szakirodalomban. A vállalkozó egyetem, vállalkozásoktatás fontossága azonban kétségtelen. Ezt mutatja az is, hogy 2012. decemberében az OECD létrehozott egy egyfajta irányadó keretrendszert, amely azon európai egyetemeket célozza meg, melyek tanácsokat, ötleteket és inspirációt keresnek az intézményi és kulturális változások hatékony kezelésére (OECD 2012).

18. ábra: OECD keretrendszer

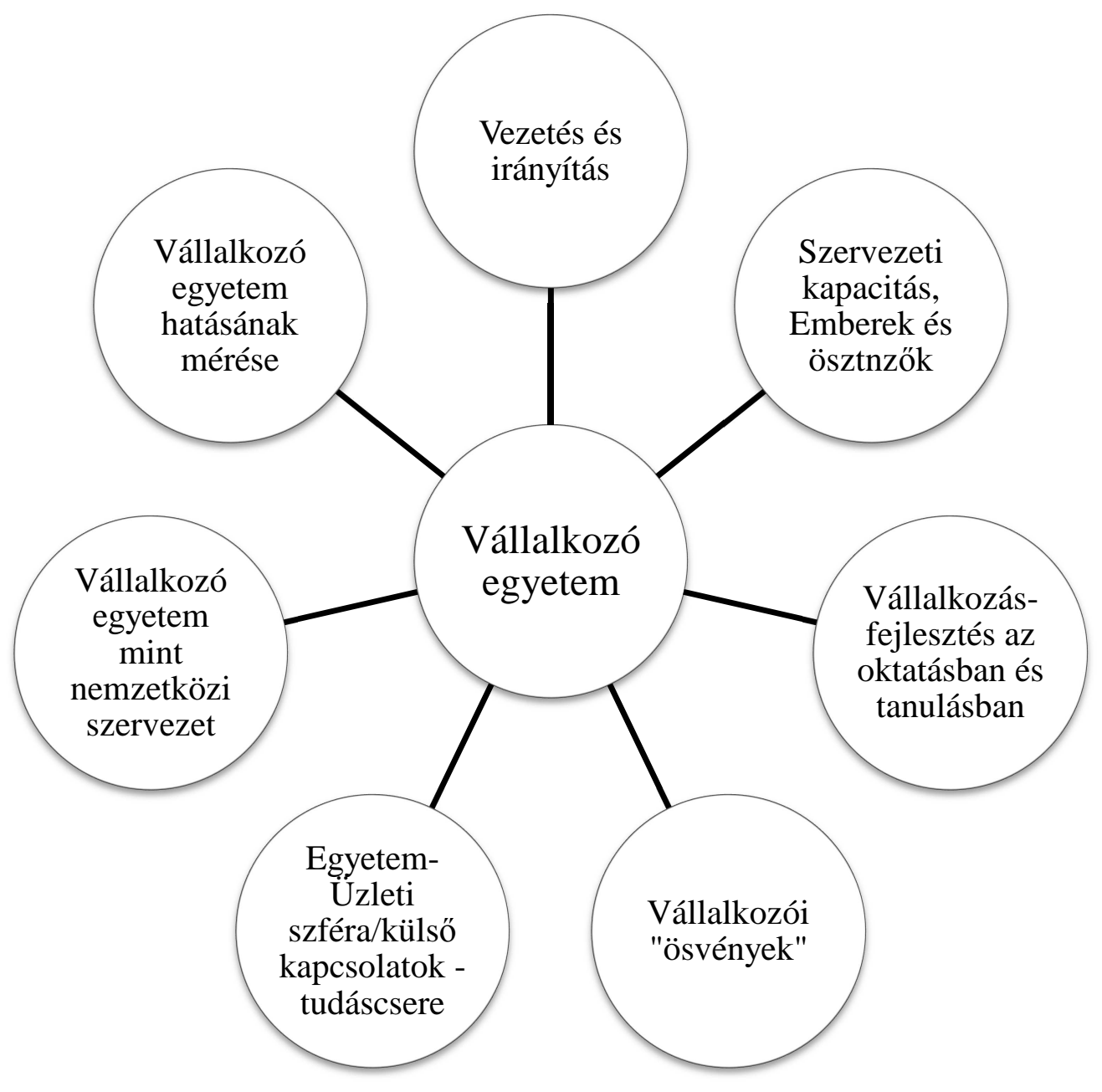

Forrás: OECD (2012) alapján saját szerkesztés 
Alapvető célja az érdekelt egyetemek segítése önmaguk értékelésében az alábbi hét területhez tartozó állítások alapján (18. ábra):

1. Vezetés és irányítás

2. Szervezeti kapacitás, emberek és ösztönzők

3. Vállalkozásfejlesztés az oktatásban és tanulásban

4. Vállalkozói ösvények

5. Egyetem - üzleti/külső kapcsolatok a tudáscserében

6. A Vállalkozói Egyetem mint nemzetközi intézmény

7. A Vállalkozói Egyetem hatásának mérése

A vezetés és irányítás esetében az iránymutatás alapján alapvető fontosságú, hogy a vállalkozástudomány az egyetemi oktatás jelentős részét képezi és a vállalkozói oktatás megvalósítása iránti nagyfokú elkötelezettség kialakítására törekszik az intézmény. Emellett az egyetem rendelkezik olyan modellel, amely az egyetem minden szintjén elősegíti a vállalkozói tevékenységek koordinálását és integrálását. Ezen belül az egyetemi karok és szervezeti egységek önállóan tevékenykedhetnek. Az egyetem a vállalkozásfejlesztés hajtóerejévé válik a szélesebb körü regionális, társadalmi és közösségi környezetben.

A szervezeti kapacitás, emberek és ösztönzőkkel kapcsolatosan az OECD kiemeli, hogy az egyetem megfelelő pénzügyi oktatást folytat a vállalkozói ismeretek fejlesztésének érdekében. Az egyetem vállalkozási céljait finanszírozási források/beruházások széles skálája támogatja, beleértve a külső stakeholderek befektetéseit is. Rendelkezésre állnak olyan mechanizmusok, melyek ledöntik a hagyományos határokat és új kapcsolatok létrejöttét segítik elö, összehozva a belső stakeholdereket (tanári kar és hallgatók) és kiépítve közöttük a szinergiát. Az egyetem nyitott a vállalkozói beállítottsággal, magatartással és tapasztalattal rendelkező szakképzett egyének toborzása és a velük történő együttmüködés felé. Az egyetem beruház személyzetfejlesztésre vállalkozásoktatási terveinek elősegítése érdekében. Egyértelmü ösztönzők és jutalmak állnak rendelkezésre az egyetem vállalkozásoktatási terveit aktívan támogató oktatók számára Az egyetem státuszt és elismerést nyújt az egyetem vállalkozásoktatási terveihez hozzájáruló stakeholderek számára

A vállalkozásfejlesztés az oktatásban és tanulásban, vállalkozásoktatást érintő, terület esetében az egyetem felépítése ösztönzi és elősegíti a vállalkozói szellem és készségek fejlesztését. Az egyetem minden részén folyik a személyzet vállalkozói képzése. A tanári kar 
minden tanszéken vállalkozói megközelítéssel oktat, elősegítve a diverzitást és az innovációt az oktatásban és a tanulásban. A vállalkozói viselkedést az egyetemi tapasztalatszerzés minden szakaszában ösztönzik, a figyelemfelhívástól és a gondolatébresztéstől a fejlesztésig és megvalósításig (vállalkozás indítás előtt, illetve indításánál). Az egyetem igazolja a vállalkozási ismeretek elsajátításának eredményeit. A külső stakeholderek bevonása kulcstényező a fejlesztés oktatásában és elsajátításában a Vállalkozói Egyetemen. A kutatási eredmények a vállalkozásoktatás és képzés részét képezik.

A vállalkozói ösvények esetében az egyetem tudatosítja a vállalkozói képességek fejlesztésének értékét/fontosságát az oktatók és a hallgatók körében. Az egyetem aktívan ösztönzi az egyéneket a vállalkozóvá válásban. Az egyetem lehetőségeket biztosít a vállalkozástudomány megtapasztalására. Az egyetem támogatást nyújt egyének és csoportok számára a vállalkozási ötletek gyakorlati megvalósításában. Rendelkezésre áll a tudományos és ipari szakemberek általi mentorálás. Az egyetem elősegíti a magánfinanszírozáshoz történő hozzájutást a potenciális vállalkozók számára. Az egyetem elérhetővé teszi az üzleti inkubációs lehetőségeket.

Az egyetem - üzleti/külső kapcsolatok a tudáscserében, az egyetem elkötelezett az iparral, a társadalommal és a közszférával történő tudáscsere iránt. Az egyetem aktívan részt vesz széles körű stakeholder partnerségekben és együttműködésekben. Az egyetem szoros kapcsolatokat ápol inkubátorokkal, tudományos parkokkal és más külső kezdeményezésekkel, lehetőséget teremtve a dinamikus tudáscserére. Az egyetem lehetőségeket biztosít az oktatók és a hallgatók számára az üzleti/külső környezetben zajló vállalkozói tevékenységekben való részvételre. Az egyetem külön támogatja az oktatói és hallgatói mobilitást az egyetem és a külső környezet között. Az egyetem összekapcsolja a kutatási, oktatási és ipari (tágabb közösségi) tevékenységeket, így gyakorolva hatást a teljes tudás ökoszisztémára.

A Vállalkozói Egyetem mint nemzetközi intézményen belül a legfontosabb kihívás, hogy a nemzetközivé válás az egyetemi vállalkozásoktatás kulcsfontosságú részévé váljon. Az egyetem határozottan támogatja az oktatók és hallgatók nemzetközi mobilitását (beleértve a $\mathrm{PhD}$ hallgatókat). Az egyetem keresi és vonzza a nemzetközi és vállalkozói oktatókat (beleértve az oktatást, kutatást és $\mathrm{PhD}$ programokat). Az egyetem nemzetközivé válási célja megmutatkozik az oktatási módszereiben. Az egyetem, annak tanszékei és karai aktívan részt vesznek nemzetközi hálózatokban. 
A hetedik és az egyik talán legnagyobb nehézséget jelentő, terület a vállalkozó egyetem hatásának mérése. Az egyetem felméri a vállalkozásoktatási stratégiájának hatását az egész intézményben. Az egyetem felméri a vállalkozói oktatásban és tanulásban történő részvétel szintjét az egész intézményben. Az egyetem felméri a vállalkozói oktatás és tanulás hatását, valamint, a vállalkozásoktatás és tanulás hatását. Az egyetem rendszeresen ellenőrzi és értékeli az egyetemek tudáscserére irányuló tevékenységeit, valamint a start-up támogatás hatását.

Értelemszerüen a fentiekben ismertetett tématerületek csak egy keretrendszert jelentenek az egyetemek vállalkozóibb szemléletüvé válásához, azonban ezt a keretrendszert az adott intézményekre jellemző egyedi specifikumok mentén „testre lehet szabni”, pontosan az eredményesebb müködés és a meglévő kompetenciák minél jobb kihasználása érdekében.

\section{5. Összegzés}

Ebben a fejezetben áttekintettem négy, egymástól teljesen eltérő elméleti és gyakorlati modellt. Célom az volt, hogy egy adott, szakirodalomra épülő szempontrendszer alapján feltérképezzem - a későbbi keretrendszer kidolgozása érdekében - milyen fő szempontok jelennek meg az egyes modellekben (13. táblázat).

13. táblázat: Áttekintett modellek adott szempontok szerinti összefoglalása

\begin{tabular}{|c|c|c|c|c|}
\hline \multirow{2}{*}{$\begin{array}{l}\text { Szem- } \\
\text { pontok }\end{array}$} & \multicolumn{4}{|c|}{ Modellek } \\
\hline & Lourenco & Fayolle-Gailly & UIUC & OECD \\
\hline 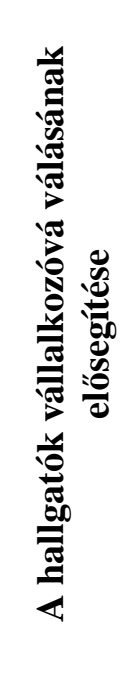 & $\begin{array}{l}\text { - vállalkozói } \\
\text { karrierutak } \\
\text { megismertetése } \\
\text { - lehetőség } \\
\text { felismerési } \\
\text { folyamat } \\
\text { elősegítése }\end{array}$ & $\begin{array}{l}\text { - lehetőség } \\
\text { felismerése } \\
\text { - iránymutatás és } \\
\text { tanácsadás fiatal } \\
\text { vállalkozók } \\
\text { számára }\end{array}$ & $\begin{array}{l}\text { • megfelelö } \\
\text { vállalkozói } \\
\text { környezet } \\
\text { kialakítása }\end{array}$ & $\begin{array}{l}\text { - } \text { elősegíti a } \\
\text { vállalkozói } \\
\text { szellem és } \\
\text { készségek } \\
\text { fejlesztését } \\
\text { - lehetőségeket } \\
\text { biztosít a } \\
\text { vállalkozástudo } \\
\text { mány } \\
\text { megtapasztalásá } \\
\text { ra } \\
\text { - elérhetővé teszi } \\
\text { az üzleti } \\
\text { inkubációs } \\
\text { lehetőségeket }\end{array}$ \\
\hline
\end{tabular}




\begin{tabular}{|c|c|c|c|c|}
\hline 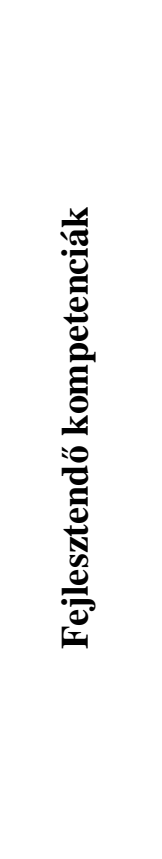 & $\begin{array}{l}\text { - kreatív } \\
\text { gondolkodás } \\
\text { - kommunikáció } \\
\text { - probléma- } \\
\text { megoldás } \\
\text { - döntéshozatal } \\
\text { - csapatmunka } \\
\text { - autonómia } \\
\text { - lehetőség } \\
\text { - keresés } \\
\text { - önbizalom } \\
\text { - kritikai } \\
\text { gondolkodás } \\
\text { - rugalmasság } \\
\text { - bizonytalanság } \\
\text { kezelése } \\
\text { - kockázat- } \\
\text { vállalás }\end{array}$ & $\begin{array}{l}\text { - kreativitás } \\
\text { - függetlenség }\end{array}$ & $\begin{array}{l}\text { - vállalkozói } \\
\text { attitüd }\end{array}$ & \\
\hline 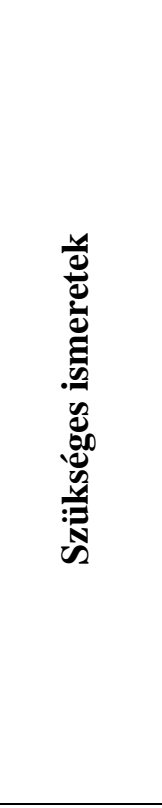 & $\begin{array}{l}\text { - vállalkozás } \\
\text { elindításának } \\
\text { folyamata } \\
\text { - vállalkozás } \\
\text { koncepciója } \\
\text { - lehetőség } \\
\text { beazonosítása } \\
\text { - kreativitás és } \\
\text { innováció } \\
\text { - marketing } \\
\text { - üzleti terv } \\
\text { - kisvállalkozás } \\
\text { menedzsment } \\
\text { - üzleti terv } \\
\text { prezentációja } \\
\text { - kutatási } \\
\text { módszerek } \\
\end{array}$ & & & $\begin{array}{l}\text { - pénzügyi } \\
\text { ismeretek }\end{array}$ \\
\hline 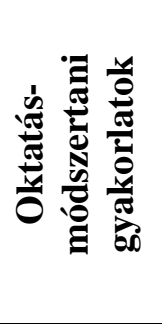 & $\begin{array}{l}\text { - workshopok } \\
\text { - cselekvés-alapú } \\
\text { tanulás } \\
\text { - problémalapú } \\
\text { tevékenységek } \\
\text { - szituációs } \\
\text { gyakorlatok }\end{array}$ & $\begin{array}{l}\text { - valóságos/virtuá } \\
\text { lis esetek } \\
\text { - szerepjátékok } \\
\text { - problémák } \\
\text { alkalmazása } \\
\text { - interjúk } \\
\text { vállalkozókkal }\end{array}$ & $\begin{array}{l}\text { • mentorhálózatok } \\
\text { létrehozása az } \\
\text { oktatók és a } \\
\text { hallgatók } \\
\text { számára }\end{array}$ & $\begin{array}{l}\text { - } \text { szakemberek } \\
\text { általi mentorálás } \\
\text { - vállalkozási } \\
\text { ötletek } \\
\text { gyakorlati } \\
\text { megvalósítása }\end{array}$ \\
\hline
\end{tabular}

Forrás: saját szerkesztés

Azonban az adott szempontrendszeren túl számos egyéb, az egyes modellekre külön-külön jellemző, azonban a későbbi modell kidolgozása szempontjából meglehetősen fontos tényező emelhető ki (14. táblázat). 
14. táblázat: Az egyes modellekből leszürhető, további fontos tényezők összefoglalása

\begin{tabular}{|c|c|c|c|}
\hline \multicolumn{4}{|c|}{ Modellek } \\
\hline Lourenco & Fayolle-Gailly & UIUC & OECD \\
\hline $\begin{array}{l}\text { - Szükség van a } \\
\text { karok közötti } \\
\text { együttmüködésre } \\
\text { - Szabványosított } \\
\text { csomagok } \\
\text { kialakítása (teljes } \\
\text { képzési anyag } \\
\text { 80\%-át } \\
\text { tartalmazza) }\end{array}$ & $\begin{array}{l}\text { - Az oktatási } \\
\text { kurzusok } \\
\text { megszületésével } \\
\text { egy időben ki } \\
\text { kell dolgozni az } \\
\text { értékelést is. } \\
\text { - A } \\
\text { vállalkozásoktatá } \\
\text { si kurzusnak } \\
\text { egyértelmü és } \\
\text { érthető célokat } \\
\text { kell megcéloznia. }\end{array}$ & $\begin{array}{l}\text { - A } \\
\text { tudományterülete } \\
\text { ken és } \\
\text { szakterületeken } \\
\text { átnyúló } \\
\text { hálózatépítés } \\
\text { elősegítése } \\
\text { - Legjobb } \\
\text { gyakorlatok/mod } \\
\text { ellek } \\
\text { megismertetése } \\
\text { és terjesztése } \\
\text { - Egyetemekkel és } \\
\text { más nemzeti } \\
\text { szervezetekkel } \\
\text { történő } \\
\text { együttmüködés } \\
\text { - Elkülönült } \\
\text { központ } \\
\text { koordinációs } \\
\text { szerepe }\end{array}$ & $\begin{array}{l}\text { - A tanári kar } \\
\text { minden } \\
\text { tanszéken } \\
\text { vállalkozói } \\
\text { megközelítéssel } \\
\text { oktat, elösegítve } \\
\text { a diverzitást és az } \\
\text { innovációt az } \\
\text { oktatásban és a } \\
\text { tanulásban } \\
\text { - Az egyetem } \\
\text { szoros } \\
\text { kapcsolatokat } \\
\text { ápol } \\
\text { inkubátorokkal, } \\
\text { tudományos } \\
\text { parkokkal, } \\
\text { lehetőséget } \\
\text { teremtve } \\
\text { dinamikus a } \\
\text { tudáscserére. }\end{array}$ \\
\hline
\end{tabular}

Forrás: Saját szerkesztés

A Lourenco-féle modell - a szakirodalommal összhangban - rámutat arra, hogy szükség van a karok közötti együttműködésre, hálózatépítésre és a vállalkozásoktatás minden karra történő kiterjesztésére. Mindez nyilván a több erőforrást, időt, karokhoz illeszkedő tematikát igényel, azonban ez a szabványosított „csomagok” segítségével viszonylag kis ráfordítással áthidalható. A másik fontos tényező az értékelés, szükség van az egyes kurzusok hatékonyságának, hatásának értékelésére, visszacsatolások megszerzésére. Továbbá, minden esetben meg kell határozni, hogy mi a célja az egyes kurzusoknak (milyen kompetenciákat, képességeket fejleszt). Az egyetemen belüli együttmüködés mellett fontos a hazai és nemzetközi egyetemekkel történő kooperáció is legyen szó egy-egy közös projektről, vagy csereprogramról. A vállalkozásoktatás talán egyik legfontosabb feladata a vállalkozói szemléletmód kialakítása és erősítése mind az egyetemi oktatók, kutatók, mind a hallgatók esetében. 


\section{Vállalkozásoktatási jó gyakorlatok}

A vállalatok két érdemi módon járulnak hozzá a piacgazdaságokhoz. Egyrészt szerves részei annak a megújítási folyamatnak, amely áthatja és meghatározza a piacgazdaságokat. A vállalkozások döntő szerepet játszanak az innovációkban, melyek technológiai változáshoz és termelékenység növekedéshez vezetnek. Röviden a változásról és a versenyről szólnak, mivel megváltoztatják a piaci struktúrát. Másrészt a vállalkozások azt az alapvető mechanizmust képviselik, amely segítségével milliók lépnek be a gazdasági főáramba. A vállalkozások emberek millióinak teszik lehetővé (beleértve sérülékenyebb csoportokat: a nőket, kisebbségeket és bevándorlókat) a gazdasági siker elérését. Ennek fényében a vállalkozókészség több, mint képesség pusztán egy vállalkozás létrehozása. Habár ez természetesen fontos részét képezi, nem jelenti a teljes képet. A lehetőségek keresésének, a biztonságon túlmutató kockázatvállalásnak és egy ötlet megvalósításához szükséges kitartás jellemzői egy vállalkozókat átjáró, speciális látásmódban egyesülnek.

Az eddigiek alapján úgy gondolom, hogy a ,vállalkozói látásmód” kialakítható az egyénekben. Ezt a látásmódot demonstrálni lehet egy szervezeten belül vagy kívül, profitorientált vagy nem profitorientált vállalkozásokban, valamint üzleti vagy nem üzleti tevékenységek során, melyek célja a kreatív ötletek létrehozása. Így a „vállalkozói véna” egy olyan integrált fogalom, amely innovatív módon járja át az egyén vállalkozását. Ez a látásmód forradalmasította a vállalkozási módot, melyet minden szinten, minden országban folytatnak.

$\mathrm{Az}$ áttekintett szakirodalom is jól mutatja, hogy az európai és amerikai döntéshozók is egyetértenek abban, hogy nagyobb mértékü vállalkozókészségre van szükség a gazdasági növekedés és innováció magasabb szintjeinek eléréséhez. Valóban, az empirikus kutatások alátámasztják a vállalkozói tevékenység és a gazdasági eredmények közötti pozitív kapcsolatot. A döntéshozók abban is hisznek, hogy a vállalkozókészség magasabb szintjét az oktatáson keresztül lehet elérni, különösen a vállalkozásoktatás segítségével. Ezért ezt a fajta oktatást számos európai tagállamban és az Egyesült Államokban támogatják és illesztik be mind a középiskolai, mind az egyetemi tantervekbe. A programok arra a feltételezésre építenek, miszerint a vállalkozói készségek taníthatóak és nem meghatározott személyes tulajdonságok. A vállalkozásösztönző programokkal kapcsolatosan igen ellentmondó vélemények, viták alakultak ki az elmúlt években, ami annak tudható be, hogy maga a vállalkozásoktatás is viszonylag gyerekcipőben jár és sem a definícióját, sem a tartalmát illetően nincs egységes álláspont. Azonban egy valamiben az egymással szemben álló felek is 
egyetértenek: a vállalkozásoktatásra szükség van függetlenül attól, hogy milyen módszertannal közelítik meg.

Az elméleti áttekintés után ebben a fejezetben olyan amerikai, angol, skandináv egyetemek vállalkozási központjait, valamint programjait vizsgálom, amelyek évek óta sikeresen müködnek és valós hatást gyakorolnak a vállalkozóvá válásra. Célom, hogy az egyes példákból az SZTE által adaptálható legjobb gyakorlatok minél szélesebb körét áttekintsem.

\subsection{Amerikai intézmények gyakorlatainak áttekintése}

Az Amerikai Egyesült Államok felsőoktatási intézményeiben tartott vállalkozásoktatási programok skálája az alapkurzusoktól a vállalkozástudományi programokon keresztül a kutatóközpontokig terjedhet. Az évente megjelenő Princeton Review bemutatja a legjobb „entrepreneurship-programmal” rendelkező intézményeket (15. táblázat).

15. táblázat: Princeton Review rangsora

\begin{tabular}{|c|c|c|c|c|}
\hline \multirow[t]{2}{*}{ Egyetem/Főiskola } & \multicolumn{2}{|c|}{ Rangsor } & \multirow{2}{*}{$\begin{array}{c}\text { Oktatók } \\
\text { vállalkozói } \\
\text { hányada (\%) }\end{array}$} & \multirow{2}{*}{$\begin{array}{c}\text { Frissen végzett } \\
\text { hallgatók, akik } \\
\text { jelenleg is } \\
\text { vállalkozók }(\%)\end{array}$} \\
\hline & BSc & MSc & & \\
\hline Babson College & 1 & 2 & 100 & 10 \\
\hline University of Houston & 2 & & 100 & 41 \\
\hline University of Southern California & 3 & 10 & 93 & 34 \\
\hline Syracuse University & 4 & & 100 & 12 \\
\hline Baylor University & 5 & & 100 & 50 \\
\hline The University of Oklahoma & 6 & 15 & 100 & 7 \\
\hline Stanford University & 7 & 6 & 53 & 13 \\
\hline Washington University in St. Louis & 8 & 12 & 62 & 61 \\
\hline Brigham Young University & 9 & 8 & 92 & 29 \\
\hline Northeastern University & 10 & & 95 & 20 \\
\hline University of Missouri-Kansas City & 11 & 20 & 100 & 95 \\
\hline Miami University & 12 & & 100 & 14 \\
\hline Temple University & 13 & 19 & 82 & 11 \\
\hline Clarkson University & 14 & & 100 & 20 \\
\hline University of Maryland, College Park & 15 & 16 & 80 & 4 \\
\hline $\begin{array}{l}\text { The University of North Carolina at Chapel } \\
\text { Hill }\end{array}$ & 16 & 9 & 90 & 12 \\
\hline University of Arizona & 17 & 14 & 70 & 46 \\
\hline University of Dayton & 18 & & 75 & 8 \\
\hline Bradley University & 19 & & 100 & 10 \\
\hline Lehigh University & 20 & & 81 & 4 \\
\hline University of Iowa & 21 & & 100 & 2 \\
\hline
\end{tabular}




\begin{tabular}{|l|c|c|c|c|}
\hline Texas Christian University & 22 & & 80 & 4 \\
\hline Saint Louis University & 23 & & 50 & 25 \\
\hline DePaul University & 24 & & 100 & 4 \\
\hline City University of New York-Baruch College & 25 & & 94 & 20 \\
\hline University of Michigan-Ann Arbor & & 1 & 53 & 2 \\
\hline Harvard University & & 3 & 40 & 7 \\
\hline Rice University & & 4 & 100 & 5 \\
\hline University of Virginia & & 5 & 100 & 6 \\
\hline The University of Texas at Austin & & 11 & 91 & 5 \\
\hline University of Chicago & & 13 & 85 & 2 \\
\hline University of Washington & & 17 & 90 & 18 \\
\hline University of South Florida & & 18 & 100 & 56 \\
\hline University of Louisville & & 21 & 45 & 57 \\
\hline Columbia Business School & & 22 & 40 & 30 \\
\hline Oklahoma State University & & 24 & 83 & 1 \\
\hline University of Utah & & 25 & 80 & N/A \\
\hline New York University & & & 8 \\
\hline The George Washington University & & 23 & \\
\hline
\end{tabular}

Forrás: saját szerkesztés ${ }^{5}$

A továbbiakban a rangsor élén szereplő egyetemeket vizsgálom a következő szempontok alapján:

- Milyen módszereket alkalmaznak?

- Milyen szakokkal, illetve kurzusokkal rendelkeznek?

- Melyek lehetnek a stratégiájuk főbb jellemzői?

Princeton Review „Top Colleges for Entrepreneurship 2013” rangsora alapján a következő, vállalkozásoktatás szempontjából élvonalbeli intézmények ${ }^{6}$ módszereit, stratégáit elemeztem:

1. Babson College

2. University of Houston

3. University of Michigan

4. Harvard University

5. University of Southern California

6. Syracuse University

7. Rice University

${ }^{5}$ A táblázat az alábbi honlapok alapján készült: http://www.entrepreneur.com/topcolleges/grad/0.html, http://www.entrepreneur.com/topcolleges/undergrad/0.html,

${ }^{6} \mathrm{Az}$ áttekintett intézmények részletes bemutatása az 1. mellékletben található. 
16. táblázat: A vizsgált intézmények adatai

\begin{tabular}{|c|c|c|c|c|c|c|}
\hline & & $\begin{array}{l}\text { Hallgatói } \\
\text { létszám (fö) }\end{array}$ & $\begin{array}{l}\text { Első képzés } \\
\text { indulása } \\
\text { (év) }\end{array}$ & $\begin{array}{l}\text { Tantestület } \\
\text { vállalkozói } \\
\text { hányada (\%) }\end{array}$ & $\begin{array}{l}\text { Frissen } \\
\text { végzettek } \\
\text { vállalkozói } \\
\text { hányada } \\
(\%)\end{array}$ & $\begin{array}{l}\text { Akik jelenleg } \\
\text { is } \\
\text { vállalkoznak } \\
(\%)\end{array}$ \\
\hline \multirow{2}{*}{$\begin{array}{l}\text { Babson } \\
\text { College }\end{array}$} & $\mathrm{BSc}$ & 2015 & 1999 & 100 & 11 & 10 \\
\hline & MSc & 1209 & 1967 & 100 & 17 & 9,2 \\
\hline \multirow{2}{*}{$\begin{array}{l}\text { University } \\
\text { of Houston }\end{array}$} & $\mathrm{BSc}$ & 1921 & 1995 & 100 & 41 & 41 \\
\hline & MSc & & & & & \\
\hline \multirow{2}{*}{$\begin{array}{l}\text { University } \\
\text { of } \\
\text { Michigan }\end{array}$} & $\mathrm{BSc}$ & & & & & \\
\hline & MSc & 2321 & 1972 & 53 & 2 & 2 \\
\hline \multirow{2}{*}{$\begin{array}{l}\text { Harvard } \\
\text { University }\end{array}$} & BSc & & & & & \\
\hline & MSc & 1151 & 1947 & 40 & 7 & 7 \\
\hline \multirow{2}{*}{$\begin{array}{l}\text { University } \\
\text { of } \\
\text { Southern } \\
\text { California } \\
\end{array}$} & BSc & 1449 & 1971 & 94 & 50 & 18 \\
\hline & MSc & 875 & 1971 & 92 & 50 & 18 \\
\hline \multirow{2}{*}{$\begin{array}{l}\text { Syracuse } \\
\text { University }\end{array}$} & $\mathrm{BSc}$ & 6715 & 1996 & 100 & 12 & 12 \\
\hline & MSc & & & & & \\
\hline \multirow{2}{*}{$\begin{array}{l}\text { Rice } \\
\text { University }\end{array}$} & $\mathrm{BSc}$ & & & & & \\
\hline & MSc & 474 & 1974 & 100 & 5 & 5 \\
\hline
\end{tabular}

Forrás: Saját szerkesztés

Az Amerikai Egyesült Államokban a vállalkozásoktatási módszerek kiforrottabbak mint hazánkban. A TOP amerikai egyetemek stratégiájának, módszereinek megismerése után az egyes példákból megpróbálom kiszürni az SZTE által adaptálható jó gyakorlatok minél szélesebb körét. Nyilvánvalóan egyszerü másolással nem érhetünk el olyan eredményeket, mint az Egyesült Államokban, hiszen amellett, hogy ezen intézményekben több évtizedes rutinnal rendelkeznek ezen a területen, jelentős társadalmi-gazdasági, valamint kulturális különbségekkel is számolnunk kell. Ezzel együtt az egyes stratégiák, módszerek egy kis finomítással, átalakítással a SZTE vállalkozásoktatási modelljének alapját jelenthetik.

A 17. táblázat a vizsgált egyetemek Szegedi Tudományegyetem által adaptálható eljárásait tartalmazza. Mivel annak nagyon kicsi az esélye, hogy egy módszer egy az egyben adaptálható legyen, a harmadik oszlopban javaslatokat teszek arra, hogy milyen 
megfeleltetések mellett (esetleg milyen) változtatásokkal lehetne az SZTE-n alkalmazni az adott eljárást.

17. táblázat: Az amerikai egyetemekről adaptálható tényezők

\begin{tabular}{|l|l|l|}
\hline \multicolumn{1}{|c|}{$\begin{array}{c}\text { Vizsgált } \\
\text { egyetemek }\end{array}$} & \multicolumn{1}{|c|}{ Adaptálható módszerek } & \multicolumn{1}{c|}{ Megjegyzések } \\
\hline Babson College & $\begin{array}{l}\text { A menedzsment és vállalkozás alapjai } \\
\text { kurzus } \\
\text { Vállalkozó Bárki Lehet } \\
\text { stratégia }\end{array}$ & ,kicsiben”Szimuláció \\
Low-tech
\end{tabular}

Forrás: Saját szerkesztés

A Babson College különdíjjal elismert „A menedzsment és vállalkozás alapjai” ${ }^{7}$ c. kurzusa, illetve ennek a logikának, tartalomnak megfelelő kurzusok szinte minden TOP egyetem esetében fellelhető. Kétségtelen, hogy a valódi, gondolkodást, illetve konkrét gyakorlatot igénylő kurzusok hatékonysága nagyobb, mint az elméleti kurzusoké. A Szegedi Tudományegyetemen első lépésben e kurzus ,kicsiben” történő megvalósítása lehet a cél. Egyfajta szimulációs programmal a csoportokba szerveződött hallgatóknak különböző

\footnotetext{
${ }^{7}$ Különdíjjal elismert kurzus: Egy éves gyakorlat, mely során a hallgatóknak 10 fös csapatonként el kell indítani egy vállalkozást, felfuttatni, majd felszámolni azt. A müködés alatt partneri kapcsolatot kell létesíteni egy szociális szolgáltatást nyújtó szervezettel, majd felszámolás után a vállalkozásból fennmaradó pénzösszeget jótékonysági célzattal eladományozzák. Ezzel is erősítve a hallgatókban a vállalkozások társadalmi felelősségvállalásnak (CSR) kiemelt szerepét.
} 
(vállalkozói életben előforduló) kihívásoknak kellene megfelelniük, így a korábban megszerzett elméleti tudás valós hasznosítása történhetne meg.

1. szövegdoboz: Vállalkozásoktatás vállalkozóvá válásra gyakorolt hatásának vizsgálata a Babson College-on

A Babson College oktatói megvizsgálták a vállalkozásoktatás vállalkozóvá válás szándékára, valamint teljes munkaidős vállalkozóvá válásra gyakorolt hatását. Közel 4000 végzett hallgatót kérdeztek meg, akik 1985 és 2009 között végeztek.

A szerzők szerint egyértelmüen bizonyítható, hogy két vagy több választható vállalkozástudományi alapkurzus elvégzése pozitívan befolyásolta a hallgatók vállalkozóvá válási szándékát és tényleges vállalkozóvá válását a diplomaszerzés idején és azt követően is. Az üzleti terv készítésének szintén jelentős hatása volt, azonban nem olyan erőteljes, mint a kurzusok teljesítésének. A szerzők fontosabb következtései az alábbiak:

1. Egyértelmü bizonyíték mutat arra, hogy két - még jobb esetben három - vállalkozási kurzus elvégzése befolyásolja a vállalkozóvá válási szándékot és a tényleges vállalkozóvá válást. Csupán egy kurzus elvégzése sokkal kisebb hatással bír.

2. Hallgatóként elkészített üzleti terv készítése hatással bír mind a hallgató vállalkozói szándékára, mind a tényleges vállalkozóvá válására, valamint befolyásolja a végzett hallgatók vállalkozóvá válási szándékát, viszont a tényleges vállalkozóvá válásukat nem.

3. A vállalkozási kurzusok elvégzésének jelentős hatása van, amely a végzést követő években is fennáll. évekkel később is fennáll.

4. A vállalkozó szülők nem bírnak jelentős hatással. Ez ellentétben áll néhány kutató eredményeivel, akik korábban már említésre kerültek. Egyik lehetséges magyarázat erre az, hogy a vállalkozásoktatás üti a szülői hatásokat.

5. A férfiak esetében nagyobb a vállalkozói szándék és a maga a tényleges vállalkozóvá válás, mint a nők esetében.

6. Nem mutatkozott különbség az alapképzésben és MBA mesterképzésben résztvevő hallgatók között a vállalkozóvá válási szándékukat és tényleges vállalkozóvá válásukat illetően, sem a diplomaszerzés idején, sem pedig később, végzett hallgatóként.

7. Minél magasabb egy végzett hallgató jövedelme, annál kisebb a valószínüsége a vállalkozóvá válási szándéknak.

8. A nappali tagozatos hallgatók vállalkozóvá válási szándéka mind a végzés idején, mind az azt követő években nagyobb, mint az esti tagozatos hallgatóké, azonban mégsem válnak nagyobb valószínűséggel vállalkozóvá.

9. A hallgatók a Babson-ra történő beiratkozás előtti vállalkozói hajlamának, valamint a későbbi vállalkozói karrierrel kapcsolatos elvárásaik kontroll változója nagyon szignifikáns volt.

Forrás: Lange et al. (2011)

A Babson gyakorlata hasonlít a Syracuse University Kisvállalkozások fejlesztése c. gyakorlatához, valamint a Michigan Egyetem MAP programjához hasonlóan egy kurzus keretében valós üzleti problémákra keresnének megoldást a hallgatók. A cél az, hogy egy 
élethű térben a hallgatók kipróbálják magukat, mint vállalkozók, viszont - való életben meglévő - kockázatok nélkül.

\title{
2. szövegdoboz: MAP bemutatása
}

\begin{abstract}
A szponzor szervezetek szemeszterről szemeszterre eljuttatnak az egyetemhez egy indítványt, melyben bemutatják a megoldásra váró összetett, üzleti problémáikat. A szervezetek lehetnek nonprofit intézmények és forprofit vállalatok egyaránt, jelentkezhetnek az USA-ból vagy a világ bármely egyéb pontjáról. A hallgatók csapata egyetemi oldalról oktatókkal, tanácsadókkal; szponzori oldalról megbízott belső emberekkel dolgozik együtt. Az gyakorlat során folyamatos egyeztetés, kétoldalú kommunikáció, ciklikusan iterált kísérletezés zajlik, majd 2 hónap letelte után a hallgatóknak jelentéssel, kész javaslatokkal kell elöállni a szponzoráló szervezet által felvetett problémát illetően. A program afféle szakmai gyakorlat és esettanulmány keverékeként képzelhető el, melyben a hallgatók valós üzleti szituációkban vesznek részt, munkájuknak valódi tétje van. Az együttmüködés az egyetem részéről azért előnyös, mert így magas szintü gyakorlati oktatást valósíthat meg, a szponzoráló szervezet pedig olcsón jut minőségi üzleti megoldásokhoz. A hallgatók által biztosított értékek itt a széles látókör, innovatív hozzáállás, üzleti háttértudás, Ross School of Business módszerek használata.
\end{abstract}

Forrás: http://www.bus.umich.edu/MAP/Dev/WhatisMAP.htm

Ugyancsak a Babson College-nál jelenik meg a „Vállalkozó Bárki Lehet” elv, azaz nem kizárólag a high-tech vállalkozókat célozzák meg, amely a Szegedi Tudományegyetem esetében is megfontolandó, hiszen a high-tech iparágakban vállalkozni kívánó potenciális vállalkozók száma elmarad a low-tech iparágakban jelenlévőktől. Éppen ezért a célcsoportok minél szélesebb körét megcélozva diverzifikált programokra van szükség.

A University of Houston Wollfest programja, illetve már a versenyeztetés önmagában fontos eleme lehet az SZTE vállalkozásoktatásának. Más magyar, illetve határon túli egyetemek hallgatói összemérhetik tudásukat, szervezőkészségüket, miközben amellett, hogy növekszik a hallgatók kapcsolati hálója, az egyetemek is tanulhatnak egymástól, ezzel egyfajta szinergikus hatáséként fejlesztik saját vállalkozásoktatási stratégiájukat. A Wollfest programhoz hasonlóan a hallgatókat be lehetne vonni konferenciák, különböző egyetemi programok szervezésébe, akár különböző karokon lévő csoportok szervezésével. Például orvosi 
konferencia szervezése, mely során orvos-, illetve közgazdász hallgatóknak egymással együttmüködve kellene megtervezniük a szükséges erőforrás (pénzügyi, humán stb.), illetve megszervezniük, levezényelniük az eseményt, akár egy kurzus keretében. Mivel az SZTE tizenegy karának, illetve kapcsolódó szervezeteinek valamelyikén minden évben rendeznek konferenciát, megfelelő alapot nyújthat a hallgatóknak, hogy valódi gyakorlati tapasztalatot szerezzenek. Az ilyen jellegü programok az olyan - tantermen belül kevésbé alakítható kompetenciákat fejleszti, mint az önállóság, kapcsolatépítés, kommunikáció, tervezésszervezés.

3. szövegdoboz: Wolffest program bemutatása

\begin{abstract}
A Wolffest program hasonlít leginkább a Babson féle „cégépítős” gyakorlathoz, bár informálisabb módon. A Wolffest a BBA in Entrepreneurship from the Wolff Center kurzus teljesítésének utolsó feltétele. A program lényege, hogy 5-6 db egyenként 8 fős csapat mérkőzik meg egymással. A cél, hogy a szemeszter végi három napos grillfesztiválon vendégül lássák az odalátogatókat (kb. 20000 ember). Egyszerüsége ellenére összetett feladatról van szó (költség- és bevétel-kalkuláció, marketing, üzleti terv írás, szponzor keresés, minőségbiztosítás, stb.) Az itt szerzett tapasztalatok megmutatják a hallgatóknak, milyen és mekkora különbségek vannak egy üzleti lehetőség tervezése és kivitelezése között.
\end{abstract}

Forrás: http://www.bauer.uh.edu/centers/wce/programs/BBA/wolffest.php

A University of Michigan kiemeli, hogy az egyetem gyakran a gazdasági fejlődés katalizátora. Ez az SZTE esetében sincs másképp, hiszen az SZTE az egyébként meglehetősen inhomogén és gazdaságilag elmaradott régióban egy „innovációs-sziget”. A SZTE esetében is elmondható, hogy az egyetemen szerzett kapcsolatok meghatározóak, az egyetem alkalmas az informális kapcsolati háló kiépítésére és megerősítésére (ImrehLukovics 2011) ${ }^{8}$. A helyben megtermelt tudás hasznosítása szintén ráhúzható az SZTE-re, hiszen különböző karokon létrejött tudás megfelelő vállalkozásoktatással lokálisan hasznosulhat. Mindezekhez szorosan kapcsolódik az ELI (Extreme Light Infrastructure) Science Park, amely jóval túlmutat egy egyszerü kutatási központ pontszerü fejlesztésén. A beruházás közvetlen környezetén túl a tágabb gazdasági térséget is érdemi fejlődésnek indul a

\footnotetext{
${ }^{8}$ A válaszadók 44\%-a teljes mértékben egyetértett azzal az állítással, hogy ,„,Az egyetemen kialakulnak olyan barátságok, személyes kapcsolatok, melyek jelentősen támogatják egy vállalkozás elindítását, üzletmenetének folytatását."
} 
várakozások szerint, azaz ez a beruházás a térség jelenlegi gazdasági szerkezetére is ráhatással lesz. A ELI Science Park térségi innovációs hatása kiemelkedő, amelynek bázisát egyrészt a konkrét fejlesztés, másrészt a Szegedi Tudományegyetem - mint Kiváló Felsőoktatási Intézmény és Kutatóegyetemi címmel rendelkező nemzetközi hírü egyetem, harmadrészt a térség további kutatóhelyei (SZBK, BayBio) jelentik. Ehhez szervesen kapcsolódnak középtávon a már meglévő, illetve a térségbe jövőben betelepülő innovatív vállalkozások.

A célcsoportok kérdéskörén belül a University of Southern California-hoz hasonlóan az SZTE-nek is érdemes lenne az orvostudomány, illetve a természettudományok területén tevékenykedő kutatókat célzó vállalkozásoktatási programokat létrehozni, hiszen ezen e területeken merülnek fel a konkrét ötletek, jönnek létre találmányok, amelyek üzleti szintre emeléséhez már nem rendelkeznek megfelelő tudással. A hallgatók informálisabb környezetben, kötetlenebb beszélgetések keretében (fórumok, előadások, mühelymunkák stb.) olyan gyakorlati tudáshoz juthatnak, amelyek kiegészíthetik a formális előadásokon hallottakat. Az SZTE alumni segítségével számos lehetőség adódik az ilyen események folyamatos létrehozására, ahol a hallgatók (és előadók) kapcsolati tőkéje is tovább növekszik. Ehhez részben kapcsolódóan a régióban lévő vállalkozások (tudásintenzív, spin-off stb.) és az egyetem számára kölcsönösen előnyös együttmüködés jöhet létre melynek keretében a vállalkozók egyetemi előadások során gyakorlati tapasztalatokkal, esettanulmányokkal, illetve interaktív előadások során adnak át tudást a hallgatóknak, mindeközben kvázi toborzást végeznek, hiszen a jó képességü hallgatók számára akár állást is ajánlhatnak. A kurzusokon akár a Syracuse Egyetem „Dilemmák és Viták” c. kurzusához hasonlóan több, eltérő megközelítés felvonultatása is érdekes lehet a problémák vizsgálata során.

A Syracuse Egyetem Entrepreneurship Field Experience kurzusa ${ }^{9}$ érdekes lehet orvostudomány és természettudományok területén lévő azon hallgatók számára, akik ki akarják próbálni magukat egy olyan környezetben, ahol saját ötletüket kell „eladni”. Véleményem szerint ez egy nagyon fontos, mert így a nem gazdász hallgatók azonnal rákényszerülnek arra, hogy üzleti szemüvegen keresztül is vizsgálják ötletüket és rutint szerezhetnek az ötletük hasznosításában.

\footnotetext{
${ }^{9}$ A kurzus során a leendő vállalkozóknak egy eredeti és megvalósítható üzleti ötlettel és az azt leíró üzleti tervvel kell előállniuk, melyet szemeszter végén egy befektetőknek tartott pitchben prezentálnak.
} 
A Harvard University-hez hasonlóan az Szegedi Tudományegyetemet, mint márkát is ki kell hangsúlyozni, hiszen a brit QS-ranglistán ${ }^{10}$ az SZTE szerepel a legjobb helyen a magyar intézmények közül. Emellett a HVG 2014-es rangsora ${ }^{11}$ alapján legjobb vidéki egyetem (az Eötvös Lóránd Tudományegyetemet, valamint a Budapesti Corvius Egyetemet követően). A harvardi „Case Method” egy nagyon intenzív módszer, amelyet „leghamarabb” master szinten lehetne bevezetni és felkészült oktatók segítségével az egyik legfontosabb kompetenciát, a döntéshozatalt ,gyakorolni”.

\title{
4. szövegdoboz: A „harvardi Case Method” bemutatása
}

\begin{abstract}
Kezdetben egyenként megkapnak egy üzleti problémát vázoló esetet. Ezt mind különkülön átolvassák, arra önállóan megoldásokat fogalmaznak meg. Ezután bemelegítő jelleggel 8 fős csapatokban megvitatják, értékelik a különböző nézőpontokat. A kurzus végső fázisában pedig elkezdődik a tényleges brainstorming. Mindannyian (80-100 fő) összegyülnek egy terembe, melyben az oktató vezetésével megvitatják a szóba jöhető (csapatok által előszelektált) ötleteket. A módszer a network effect-re épít, ami azt jelenti, hogy az oktatóterem különböző tudományos háttérrel, tapasztalattal, ipari rálátással, rendelkező hallgatók olvasztótégelyévé válik. Olyan üzleti megoldásokat kínáló csoport jön létre, melyben nincs hierarchia, tehát az információ a lehető legszabadabban áramlik (az év végi osztályzat 50\%-a az órai aktivitásból tevődik ki). Az oktató ez esetben nem mindentudó szakértőként, hanem - néha provokatívan - olyan katalizátorként müködik, mely előhozza az emberekből a bennük rejlő vezetőt. Így a kurzus végére olyan kollektív tudáshalmaz kerül felszínre, mely a lehető legtöbb nézőpontból vizsgál egy estet. Voltaképpen az oktató közremüködésével a hallgatók tanítják egymást (plusz az oktatót is!). A kurzus végső célja a döntéshozatal gyakoroltatása. A valós élethez hasonlóan, néha hiányos vagy ellentmondó információk birtokában, nyomás alatt is.
\end{abstract}

Forrás: http://hbsp.harvard.edu/product/casemethodteaching

Az amerikai vezető egyetemek közül a Princeton Review 20. helyén álló Lehigh University-n müködő Baker Institute vezetőjével, Todd A. Watkins-al sikerült írásban interjút készíteni. Mr. Watkins elmondta, hogy a Lehigh University nagy lépéseket tett a vállalkozói környezet és a hallgatói startup folyamat kiépítésében egyetem szerte a Baker Institute for

\footnotetext{
${ }^{10}$ http://www.topuniversities.com/university-rankings/world-universityrankings/2013\#sorting=rank+region=140+country=+faculty=+stars=false+search=

${ }^{11}$ A HVG rangsorát az Emberi Erőforrások Minisztériuma, az Oktatási Hivatal és az Educatio Nonprofit Kft. adatainak felhasználásával készítették.
} 
Entrepreneurship, Creativity and Innovation és a Lehigh vállalkozást elősegítő programjainak ösztönzésével.

\title{
5. szövegdoboz: LehighSiliconValley program a Lehigh University-n
}

\begin{abstract}
A LehighSiliconValley program 2012 januárjában indult és 2014 januárjában már harmadjára futott. LehighSiliconValley egyedi az egyetemi vállalkozási programok között. A Baker Institute 40-50 egyetemistát és 10-15 diplomást visz el a vállalkozás központjába, a Szilícium-völgybe. Kihasználva a Lehigh 80 mérföldes távolságát New Yorktól, 2013-ban ezt kiegészítették a hivatalos LehighSiliconValley programot a „New York Experience” programmal, lehetőséget nyújtva a hallgatóknak, hogy két napig elmerüljenek New York vállalkozási dzsungelében. Így a hallgatók össze tudták hasonlítani mindkét partvidék vállalkozói környezetét.
\end{abstract}

Az „élő esetek” felhasználása izgalmas tanulási környezetet eredményez, amely valódi vállalatokra, valódi szereplőkre és valós időben játszódó valódi helyzetekre koncentrál. az „élő eset” során az alapító ügyvezető igazgatók bemutatják vállalatukat a csoportnak, hasonlóan ahhoz, amikor befektetőknek prezentálják. Jellemzik a vállalkozást, megosztják az elképzeléseiket és előremutató stratégiákat közölnek. Előre kiosztanak anyagokat a cégről és az iparágról, hogy a hallgatók rákészüljenek. A hallgatók csapatokban együttmüködve elemzik és értékelik a látottakat és hallottakat; megvitatják a problémákat és megegyezésre jutnak; majd formálisan bemutatják megállapításaikat, következtetéseiket és javaslataikat - közvetlenül az alapító ügyvezető igazgatónak.

A program népszerüségének köszönhetően 2013 áprilisában a keleti parton tovább terjeszkedtek egy új kísérleti programmal, a LehighBostonStartup programmal. A Szilícium-völgyi program egyetemi közfigyelme elvezetett egy csoport elkötelezett végzett hallgatóhoz és más vállalkozókhoz, kockázati tőkésekhez és inkubátor szakemberekhez Boston területén, akik hajlandóak megosztani új vállalkozási tapasztalataikat és kapcsolataikat 40 hallgató számára gyakorlati, New England stílusú tapasztalatszerzés keretében. A LehighBostonStartup egy rövidebb, három napos terepgyakorlat volt, mely a LehighSiliconValley programhoz hasonlóan élő eset módszerre épült.

Forrás:megkérdezés alapján saját szerkesztés

2012-13-ban több mint 65 valódi startup (nem osztálytermi projektek) állt az indítás különböző fázisaiban az egyetemen. A Baker Institute programjai, workshopjai, kapcsolódó eseményei több mint 3500 részvevőt számláltak 2012-2013-ban. Két, egyetemisták által elindított startup elismerést vívott ki a közelmúltban: az EcoTech Marine bekerült az Inc500 
leggyorsabban növekvő vállalatainak listájába az USA-ban; valamint a LifeServe Innovation társalapítói felkerültek a BusinessWeek Amerika Legjobb Fiatal Vállalkozóinak Top 25-ös listájára. Mr. Watkins - az előző intézmények gyakorlatához hasonlóan - a gyakorlati oktatás fontosságát hangsúlyozza, amit a LehighSiliconValley program elindítása is bizonyít.

Mivel a vállalkozásoktatás nem a felsőoktatás szintjén kellene, hogy kezdődjön, hanem általános és középiskolai szinten is szükséges lenne alapismeretek elsajátítására, így a Rice Egyetemhez hasonlóan az SZTE is indíthatna általános és középiskolai tanárok részére képzéseket, amelyek segítségével a vállalkozásoktatás már fiatalkorban elkezdődhet. Érdemes lenne gyakorló iskolákban néhány kísérleti képzést indítani, amelyet először egyetemi oktatók tartanának és felmérni, hogy a képzést elvégző tanulók mennyire profitáltak a képzésböl.

\subsection{Európai egyetemek gyakorlatainak áttekintése}

Az amerikai példák áttekintése után, megvizsgáltam az európai TOP felsőoktatási intézményeket, amelyek mind kulturálisan, mind földrajzilag közelebb helyezkednek el hazánkhoz. Kutatásaim során számos iskolát elemeztem, a részletesen vizsgált intézmények a MBA50.com Premiership 2013 rangsorolása alapján kerültek kiválasztásra. Tekintve, hogy a különféle elektronikus üzleti folyóiratok (Financial Times, Bloomberg Businessweek, The Economist, Forbes) különböző indikátorokat használnak éves egyetemi rangsorolásuk elkészítéséhez, az MBA50.com célul tüzte ki, hogy egyenlő súllyal egységesíti a rendszereket, és a különböző rangsorokból létrehoz egy összesített rangsort, a Premiership 2013-at. Ezek alapján tíz vezető, európai intézményt vizsgáltam (18. táblázat).

Mielőtt rátérnénk az egyes egyetemek vizsgálatára, vázlatosan tekintsük át, mi alapján állítják fel sorrendjüket a különböző szerkesztőségek:

- Financial Times: Az alumnik éves fizetése, 3 évvel a végzés után, illetve százalékos növekedés a képzés előtti és utáni (+3 év) éves fizetésben.

- Bloomberg Businessweek: kérdőívek a fő érintetteket figyelembe véve: hallgatók, leendő munkaadók. Ezen kívül kisebb súllyal megjelenik az oktatói-hallgató összetétel, az alumnik éves fizetése, illetve egyéb - az egyetemre vonatkozó minőségi összetevők.

- The Economist: karrierlehetőségek, hallgatók személyes fejlődése (oktatás révén), éves fizetés, networking lehetőségek. 
- Forbes: ROI 5: Milyen mértékben térülnek meg a végzéstől számított 5 éves távlatban a képzés költségei?

18. táblázat: Vizsgált európai intézmények rangsora

\begin{tabular}{|c|l|l|c|c|c|c|}
\hline $\begin{array}{c}\mathbf{2 0 1 3} \\
\text { Össze- } \\
\text { sített } \\
\text { Rang- } \\
\text { sor }\end{array}$ & \multicolumn{1}{|c|}{$\begin{array}{c}\text { Európai üzleti } \\
\text { intézmények }\end{array}$} & \multicolumn{1}{|c|}{ Ország } & $\begin{array}{c}\text { Financial } \\
\text { Times } \\
\mathbf{2 0 1 3}\end{array}$ & $\begin{array}{c}\text { Business } \\
\text { Week 2012 }\end{array}$ & $\begin{array}{c}\text { Eco- } \\
\text { nomist } \\
\mathbf{2 0 1 3}\end{array}$ & $\begin{array}{c}\text { Forbes } \\
\mathbf{2 0 1 3}\end{array}$ \\
\hline $\mathbf{1}$ & $\begin{array}{l}\text { London Business } \\
\text { School }\end{array}$ & $\begin{array}{l}\text { Egyesült } \\
\text { Királyság }\end{array}$ & 1 & 1 & 3 & 4 \\
\hline $\mathbf{2}$ & Insead & Francia-ország & 2 & 2 & 7 & 2 \\
\hline $\mathbf{3}$ & IMD & Svájc & 6 & 7 & 4 & 1 \\
\hline $\mathbf{4}$ & Iese Business School & $\begin{array}{l}\text { Spanyol- } \\
\text { ország }\end{array}$ & 3 & 6 & 1 & 12 \\
\hline $\mathbf{5}$ & IE Business School & $\begin{array}{l}\text { Spanyol- } \\
\text { ország }\end{array}$ & 4 & 3 & 15 & 5 \\
\hline $\mathbf{6}$ & $\begin{array}{l}\text { University of } \\
\text { Cambridge - Judge }\end{array}$ & $\begin{array}{l}\text { Egyesült } \\
\text { Királyság }\end{array}$ & 5 & - & 9 & 8 \\
\hline $\mathbf{7}$ & Esade Business School & $\begin{array}{l}\text { Spanyol- } \\
\text { ország }\end{array}$ & 8 & 5 & 5 & 14 \\
\hline $\mathbf{8}$ & HEC Paris & Francia-ország & 7 & 9 & 2 & 15 \\
\hline $\mathbf{9}$ & $\begin{array}{l}\text { University of Oxford - } \\
\text { Saïd }\end{array}$ & $\begin{array}{l}\text { Egyesült } \\
\text { Királyság }\end{array}$ & 9 & 4 & 17 & 6 \\
\hline $\mathbf{1 0}$ & SDA Bocconi & Olasz-ország & 14 & 10 & 14 & 3 \\
\hline
\end{tabular}

Forrás: www.mba50.com alapján saját szerkesztés

A továbbiakban az amerikai egyetemek adaptálható legjobb gyakorlatainak további tesztelése érdekében áttekintettük, hogy a kiemelt pozitív módszerek milyen mértékben és milyen módon jellemzők a vezetői európai egyetemek gyakorlatára. Ezzel azt megvizsgáltuk, hogy az egyes intézményekben milyen valóban adaptálható módszerekkel találkozhatunk. Összességében a leggyakrabban ismétlődő megoldásokat kerestük, vélelmezve, hogy a legjellemzőbb megoldások az európai környezetben és értékrendben is általánosságban müködőképesek.

A leggyakrabban ismétlődő motívumok az alábbiak:

- Nemzetközi tapasztalatszerzés

- High-tech vállalkozások részére speciális képzés

- Modern oktatási módszerek: szimuláció, szerepjáték

- Vállalkozók bevonása az oktatásba

- Esettanulmányok csoportmunkával

- Szervezetek hallgatóknak 
Az egyik legfontosabb sikerfaktornak a nemzetközi tapasztalatszerzés tűnik. Vélelmezhetően a nemzetközi, illetve multikulturális tapasztalat egyrészt az önállóságot is növeli, másrészt többféle nézőpont elsajátítását is elősegítheti. Nem véletlen, hogy az amerikai egyetemekhez hasonlóan a területen vezető európai egyetemek is kiterjedt lehetőségekkel rendelkeznek. A teljesség igény nélkül a legjellemzőbb példák. A London Business School esetében a hallgatóknak lehetőségük van 32 intézet közül választani Európában, Ázsiában, Ausztráliában, Észak- és Dél-Amerikában. Az Insead-en hihetetlen multikulturális az oktatói és hallgatói gárda egyaránt - a világ 84 különböző országából tevődnek össze a szereplők. Hasonló módon az IESE-n kitüntetett figyelmet fordítanak a nemzetközi csereprogramokra, illetve az ESADE-n is 3-4 hónapos csereprogramok érhetőek el, mivel partneri viszonnyal rendelkeznek a világ legnevesebb üzleti egyetemeivel.

Szintén szinte mindenhol megjelenik a leendő high-tech vállalkozások elindítását elősegítő speciális képzések kérdésköre. A széles képzési portfólióval rendelkező európai egyetemeknél bevett gyakorlat a nem üzleti képzésben részt vevő hallgatók, kutatók felkészítése a vállalkozóvá válásra. Ilyenek például a Cambridge-ben működő MPhil programok, amelyek nem üzleti MSc-n végzetteknek, vagy jelenleg PhD-s kutatóknak szólnak, és képessé teszik őket, hogy szakterületükhöz kapcsolódó vállalkozást indítsanak el. Hasonló az ESADE Business School keretein belül müködő Master in Innovation and Entrepreneurship, amely kifejezetten high-tech vállalkozások indítására felkészítő képzés.

Az amerikai egyetemekhez hasonlóan a vizsgált egyetemek szinte mindegyikén elötérbe kerülnek a tantermi oktatás mellett a modern, szimulációra, szerepjátékra épülő oktatási módszerek. Ezek közül kiemelhető a SDA Bocconi School of Management Learning Lab gyakorlata, amely keretében menedzsment szimulációs programot (Sherlock), szerepjátékot. web-based solution-okat fejlesztettek ki. Kijelenthetjük a sikeres vállalkozásoktatás egyik meghatározó alappilére a modern oktatási módszerek konzekvens alkalmazása.

Alapkövetelmény a gyakorló vállalkozók bevonása az oktatásba, ez minden amerikai és európai egyetem gyakorlatában megjelenik. A London Business School esetében éves díj ellenében a nagyvállalati partnerek értékes, mindkét fél számára előnyös, szolgáltatásokat kapnak az egyetemtől (pl. hallgatók (munkaerő) rendelkezésre bocsátása, Üzleti elemzések, módszerek, legfrissebb kutatás, Globális kapcsolati háló stb.). Hasonlóan, az IMD szintén lehetőséget biztosít vállalati szereplőknek, hogy együttmüködjenek az egyetemmel, illetve 
éljenek annak szellemi tőkéjével. Ennek megfelelően a következő szolgáltatásokat biztosítják az ügyfeleknek: toborzás (a cégek MBA hallgatókból válogathatnak), startup projektek: a hallgatók besegítenek technológiai startupok „felpörgetésébe” (ez egyúttal üzleti gyakorlati lehetőség is számukra), illetve konzultációs szolgáltatás (érettebb vállalkozások üzleti kihívásaira egy erre kinevezett hallgatói csapat végez elemzést, majd kínál megoldást).

Szintén jól bevált eszköz az esettanulmányok megoldása csoportmunka keretein belül. Az IESE Business School gyakorlatilag direktben a Harvard „Case Method” módszertanát használja, ahol a hallgatók e kurzuson mindannyian döntéshozó személyként vesznek részt. Kezdetben egyenként megkapnak egy üzleti problémát vázoló esetet. Ezt mind külön-külön átolvassák, arra önállóan megoldásokat fogalmaznak meg. Ezután bemelegítő jelleggel 8 fős csapatokban megvitatják, értékelik a különböző nézőpontokat. A kurzus végső fázisában pedig elkezdődik a tényleges brainstorming. Mindannyian (80-100 fö) összegyülnek egy terembe, melyben az oktató vezetésével megvitatják a szóba jöhető (csapatok által előszelektált) ötleteket. Hasonló megoldás a Insead-en alkalmazott, ahol a Harvard 'Case Method' kurzusához hasonlóan itt is megjelenik a szerepjáték, valamint az előadás interaktív levezénylése (az oktató részben, mint „provokatív müsorvezető” funkcionál).

Végül nem mellékes a hallgatói szervezetek keretein belül folytatott tevékenység sem, amely szintén önállóságra, mérlegelésre és tervezésre neveli a résztvevő hallgatókat (pl: EGarage az ESADE-n; Business clubs az INSEAD-on).

A fentiek mellett kiemelném a University of Cambridge-n müködő Judge Business School vállalkozói attitüd kialakításával kapcsolatos törekvését, amit az SZTE is adaptálhatna. Az Üzleti Iskolának egy külön, erre a célra létrehozott központja (Centre for Entrepreneurial Learning) foglalkozik az egyénekben rejlő vállalkozó felébresztésével. E misszióval összhangban a központ különféle kurzusokat, képzéseket, konferenciákat, rendezvényeket szervez, hogy elösegítse e képességek kibontakoztatását. Ezek között szerepelnek hetente megrendezésre kerülő networking események; technológiai kutatásokból innovatív vállalkozások létrehozását célzó kezdeményezések; vállalkozói készségeket feltáró és fejlesztő képzések; valamint meghívott előadók, vállalkozók révén inspiráció, know-how, átadása; tanácsadás, mentorálás. Hasonlóan a University of Oxford tagintézménye a Saïd Business School is törekszik arra, hogy megfelelő vállalkozói légkör alakuljon ki. Egyik ilyen a Vállalkozói központ létrehozása, mely szemináriumokat, networking rendezvényeket tart; 
versenyeket szervez; különféle vállalkozói képzéseket, támogatást nyújt. E sikerekben (indulástól számítva több mint 150 megalapított cég; 22000 résztvevö a kurzusokon, rendezvényeken; 2,5 millió letöltés - szabadon hozzáférhető elöadások, hanganyagok) valószínüleg az is közrejátszik, hogy az egyetem megfelelően tudja tolmácsolni a menedzsmenti és vállalkozói létforma közti különbséget. Így - talán a nagyobb társadalmi elfogadottság következtében - több emberhez tudnak eljutni az inspiráló sikertörténetek.

A másik ilyen szervezet az Oxford Entrepreneurs. Ez egy a hallgatókat, az alumnit és külső szereplőket is tömörítő fórum, mely 10.000 tagjával valószínűleg méltán nevezheti magát Európa legnagyobb hallgatói vállalkozói közösségének. Kapnak támogatást az egyetem Vállalkozói központjától, de formálisan függetlenek tőle. Ök hallgatói oldalról közelítik meg a fiatal vállalkozók szükségleteit, és ennek megfelelően támogatják őket: inspiráció, oktatás, networking, versenyek, tanácsadás. Végül, de nem utolsó sorban pedig mindkét szervezet szoros kapcsolatot ápol az egyetem technológia transzfer társaságával (Isis Innovation).

Továbbá, ugyancsak a Judge Business School felismerte a „soft skills”-ek erősítésének fontosságát. E kifejezés alatt főleg az érzelmi intelligenciához köthető kvalitásokat értjük: kommunikációs készség; stílus (közvetlenség, megnyerő fellépés); optimizmus; segítőkészség; kooperációs hajlam; stb. E készségek nemcsak kiegészítik, de „tálalják és el is adják" a hard skill-eket (szaktudás, tapasztalat, végzettség - mindazok a formai követelmények, amelyek egy pozíció betöltéséhez szükségesek).

Tekintve, hogy jelen világunkban egy hard felől soft irányú gazdasági és társadalmi átalakulás megy végbe, e képességek a későbbiekben valószínűleg még nagyobb szerepet kapnak.

Azért a hasonlóságok mellett érdemes röviden rávilágítani a legmarkánsabb különbségekre is a sikeresebb adaptáció érdekében.

Az Egyesült Államoktól eltérően (feltehetőleg jórészt kulturális különbözőségek miatt) arányaiban az európai országok lakóira nem annyira jellemző, hogy alapfokú diplomával fogjanak vállalkozás-indításba. Ehelyett - talán társadalmi nyomásra is - jellemzőbb, hogy szükségesnek tartjuk mesterfokú végzettség megszerzését is.

Az Amerikai egyetemeknél gyakran előfordultak olyan kurzusok, melyek a hallgatókat célzottan valós üzleti tapasztalatszerzéshez segítették (Babson College: Foundations of Management and Entrepreneurship; University of Houston: Wolffest; University of 
Michigan: Multidisciplinary Action Projects; Syracuse University: Emerging Enterprise Consulting; Rice University: Action Learning Project). A London Business School esetében a nyári gyakorlatok hasonlíthatók leginkább az imént említett kurzusokhoz. Didaktikai elrendezésüket tekintve azonban erősen elüt egymástól az amerikai és európai gyakorlat. Ez a következőt jelenti: az amerikai példánál a gyakorlati kurzusok sokkal inkább az oktatásba integráltak, míg európai esetben inkább kiszervezettek, elkülönülők. Az előbbi eset horizontálist (a hallgató egyszerre halad a tanulmányaival és vállalkozói törekvéseivel), az utóbbi vertikalitást feltételez (a hallgató egyik periódusban inkább a tanulmányaira, a másik periódusban inkább a vállalkozására koncentrál). Jóllehet, e különbözőség adódhat abból, hogy az amerikai egyetemek rangsorolása vállalkozói képzésekre volt kihegyezve, míg az európaiaké tágabb értelemben vett üzleti képzésekre. Értékes tanulság mindenesetre, hogy vállalkozói képzések tekintetében valószínúleg jobban beválik a tananyagba integrált gyakorlat (amerikai stílus), hiszen a két terület (üzleti tudás [elmélet] + vállalkozói tapasztalat [gyakorlat]) egy időben, kölcsönösen tudja egymást fejleszteni.

Végezetül röviden kísérletet teszünk néhány alapvető fontosságú feltétel megfogalmazására, amelyeket feltétlenül érdemes figyelembe venni, amikor az esetleges adaptációs lehetőségek kidolgozása történik a kelet európai egyetemekre.

A nemzetközi tapasztalatszerzés itt is alapkövetelmény, szerencsére az elmúlt néhány évben ezen a területen is megnőttek a lehetőségek. Sajnos a külföldi tapasztalatszerzés a jelenlegi keleti-nyugati relációban az esetek egy részében csak utazgatás. Praktikus olyan kapcsolatokat létesíteni, ahol a partnerintézmények valóban színvonalas képzést nyújtanak többek között a vállalkozástudomány területén is, így a tudásátadás direktebb formában is megvalósulhat. Ennek még konkrétabb formája, ha a kint tartózkodás egyik alapkövetelménye valamilyen „entrepreneurship” kurzus teljesítése a fogadóintézményben.

A high-tech vállalkozások részére adaptálható speciális képzések kulcsfontosságúak, praktikus minden intézménynek kialakítani a saját portfólióját, amely pontosan a jó nemzetközi gyakorlatból tevődik össze. Emellett nem szabad elfelejtkezni az esetleges Lowtech képzések innovációs képzésekről sem. A kelet európai egyetemekről esetlegesen kipörgő spin-off-ok jelentős része inkább ezen ágazatokból kerül ki.

A modern oktatási módszerek esetében fontos arra figyelni, hogy az adott szerepjátékok szimulációk az adott gazdasági társadalmi kulturális környezethez illeszkedjenek. Ilyen 
értelemben ezen a területen inkább a módszertan adaptálható csak, a konkrét tartalommal történő megtöltés az már inkább saját feladat.

Talán a vállalkozók bevonása az oktatásba az egyik legnagyobb kihívás a kelet európai egyetemek számára. Ennek nincs igazán érdemi hagyománya ebben a térségben, illetve az alumni mozgalmak is messze elmaradnak a nyugati gyakorlattól. Itt a „nulladik lépés” a sikeres bevonási módszerek adaptációja lehetne, mert még ebben is komoly lemaradásaink vannak.

A megfelelően használt esettanulmányok szintén komoly lehetőségeket rejtenek magukban. Itt is kulcsfontosságú azonban észrevenni, hogy a módszertan átvétele lehet az előrelépés, nem pedig az esettanulmányok maradéktalan átvétele. Számos sikertelen próbálkozás során sikerült megtanulni, hogy a vezető amerikai és európai egyetemek esettanulmányainak direkt átvétele nem jelent komoly előrelépést az entrepreneurship oktatásban, pontosan az eltérő makro- és mikrokörnyezet következtében. Ezen a területen is - hasonlóan az oktatási módszereknél említettekhez - a konkrét valóban használható esettanulmányok kidolgozása már saját feladat.

A hallgatói öntevékeny csoportok esetén törekedni kell a minél üzleti jellegü gondolkodásmód elsajátítására, illetve a projektszemlélet előtérbe helyezésére. Ezen a területen is az egymástól tanulás rejti magában a legtöbb lehetőséget.

\section{3. Összegzés}

A továbbiakban a szakirodalmi áttekintés és szekunder kutatásom alapján megfogalmazható téziseimet ismertetem. Az itt bemutatott tézisek egyrészt összegzik az eddigiekben áttekintett ismereteket, másrészt alapot szolgáltatnak a primer kutatásom és az SZTE vállalkozásfejlesztési-vállalkozásoktatási modellem keretrendszerének.

1. Tézis: A vállalkozói attitüd annak ellenére, hogy részben veleszületett tulajdonságokon, részben pedig gyermekkori szocializáción alapul, vállakozásoktatással kialakitható, söt megerösíthetö még a felsőoktatás keretein belül is.

Kutatásomban részletesen elemeztem, hogy számos tényező befolyásolhatja a vállalkozói attitüd kialakulását, vállalkozóvá válást (közvetlen környezetben van-e vállalkozó, veleszületett tulajdonságok, vállalkozói attitüd mikor kezd kialakulni stb.), de az egyik 
legmeghatározóbb tényező: az oktatás. Kísérletet tettem annak igazolására, hogy a vállalkozásoktatás megfelelő eszköznek tekinthető az újonnan létrehozott vállalatok túlélési és sikerességi rátájának növelésében. A felsőoktatás alapvetően két módon járulhat hozzá a vállalkozói attitűd kialakulásához, megerősítéséhez: ismeretátadással és vállalkozói készségek fejlesztésével. .

2. Tézis: A módszertanilag megalapozott üzletviteli, menedzsment ismeretek mind a vállalkozás indításában, de különösen a vállalkozás sikeres müködtetésében nagy jelentöséggel bírnak, ezért ezek is szükséges, de nem elégséges feltételei a vállalkozóvá válásnak.

A szakirodalom hangsúlyozza, hogy a vállalkozói ismeretek és a menedzsment ismeretek nem azonosak egymással, ezzel együtt szorosan kapcsolódnak és mindkettőre szükség van a sikeres vállalkozásoktatás megvalósításához. Annak ellenére, hogy az üzleti, üzletviteli ismeretek elsajátítása nem azonos a vállalkozói kompetencia-fejlesztéssel, kutatásaim meggyőztek arról, hogy általánosságban még az ilyen ismeretek oktatásában is vannak előrelépési lehetőségek, mert a felsőoktatási gyakorlat még ezeknek a kihívásoknak sem tud gyakran megfelelni. Az ilyen jellegü tárgyi tudás ismertetése bevezető lépése lehetne a vállalkozóvá váláshoz szükséges ismeretek átadásának.

3. Tézis: A vállalkozói kompetenciák egy része tanulható, illetve oktatási tevékenységgel fejleszthetö. Ezért a felsöoktatásban a hatékony vállalkozásoktatáshoz elengedhetetlen a vállalkozói készségek, kompetenciák tudatos fejlesztése.

Annak ellenére, hogy a vállalkozásoktatás keretein belül az oktatók nem képesek vállalkozókat „létrehozni”, ahogy nem tudják a vállalkozói siker receptjét sem megalkotni, rámutattam, hogy azért oktathatják az új vállalkozás elindításához, illetve müködtetéséhez szükséges ismereteket. Ehhez azonban elengedhetetlen - megfelelö módszertan alkalmazásával - a hallgatók vállalkozói kompetenciáinak fejlesztése, amelyek olyan módszerekkel alakíthatók mint például workshopok, cselekvés-alapú tanulási módok, problémalapú tevékenységek, szituációs gyakorlatok, vagy akár valódi vállalkozás megalapításában részvétel. Attól függően, hogy ismeretátadás, vagy készségek fejlesztése a cél, eltérő módszertant szükséges alkalmazni a vállalkozásoktatás során. 
4. Tézis: A vállalkozói kompetenciák fejlesztésében egyértelmüen kulcsfontosságú az ismeretátadási-készságfejlesztés megfelelö arányának kialakítása. Az általános gyakorlati túlsúly mellett azért megfelelö figyelmet kell fordítani a tantermi oktatási megoldásokra is.

A vállalkozásoktatás négy alapvető célja a vállalkozói szemléletmód kialakítása, új vállalkozás indításához és müködtetéséhez szükséges ismeretek biztosítása, illetve vállalkozói készségek, képességek fejlesztése. A vállalkozásoktatás során egyaránt figyelmet kell fordítani az új vállalkozás létrehozásának aspektusaira (jellemző problémák áttekintése a kezdeteknél), valamint az üzleti ismeretekre (menedzsment, üzleti terv, kockázati töke bevonás), amelyek meglehetősen fontosak a növekedés későbbi szakaszaiban is. A vállalkozásoktatás alapvetően három, logikailag is egymásra épülő formában valósulhat meg: tantermi oktatási forma, szimulatív vállalkozás, illetve valódi vállalkozás létrehozása.

A tantermi oktatási forma (pl. tanári előadás, meghívott előadók) az ismeretek átadására koncentrál, nem igazán alkalmas a vállalkozói készségek fejlesztésére, azonban azoknak egy megfelelö alapot tud biztosítani a szükséges elméleti háttér átadásával. Emellett az ismertetett esetpéldák és vállalkozó létformákba történő bevezetés a vállalkozói attitüdformálásban nagy szerepet játszik. A szimulatív vállalkozás esetében már vállalkozói képességek, készségek fejlesztéséről is beszélhetünk, hiszen ebben az esetben már gyakorlatban ismerkedhetnek a hallgatók a vállalkozói léttel, anélkül, hogy a valós kockázatokkal számolniuk kellene. Végül, a valódi vállalkozás alapítása során már „kézzelfoghatóvá” válik a vállalkozói létforma, hiszen a hallgatók megtapasztalják, hogy milyen vállalkozónak lenni. A sikeres vállalkozásoktatás egyik meghatározó alappillére a modern oktatási módszerek konzekvens alkalmazása.

5. Tézis: A felsőoktatás keretein belül a vállalkozóvá válás elösegítéséhez megfelelö szervezeti kompetenciákkal és kidolgozott vállalkozásfejlesztési-, vállalkozásoktatási stratégiával bíró szervezeti egységekre van szükség.

A vállalkozó egyetem hármas missziója (oktatás-kutatás-vállalkozás), illetve a nemzeti és uniós célkitüzések (vállalkozói oktatás és képzés, vállalkozói környezet kialakítása, valamint társadalom problémás csoportjainak támogatása) is alátámasztják, hogy az egyetemeknek meghatározó szerepük lehet a vállalkozóvá válás kialakításában. A sikeres felsőoktatási intézményi modellek, példák egyértelmüen rámutattak arra, hogy szükség van megfelelő szervezeti kompetenciákkal és kidolgozott vállalkozásfejlesztési-, vállalkozásoktatási 
stratégiával bíró szervezeti egységekre. Kutatásomban rámutattam arra, hogy a sikeres intézmények az esetek egy jelentős részében több (egy-egy területre specializálódott) központtal rendelkeznek, amelyek különbözö szolgáltatásokat nyújtanak: mentorálás, tanácsadás, képzések, vállalkozói szemléletformáló rendezvények. 


\section{SZTE Vállalkozásfejlesztési-, vállalkozásoktatási modell kereteinek kialakításával kapcsolatos primer kutatások}

A vállalkozásoktatás szerepe hazánkban is egyre inkább előtérbe került és több kezdeményezés is elindult az elmúlt években. A Budapesti Corvinus Egyetemen 2000-ben Kisvállalkozás-kutató Csoport megszűnése után megalakult a Kisvállalkozás-fejlesztési Központ (KFK). A Pécsi Egyetem Közgazdaságtudományi Karán létrejött a Simonyi Üzlet-, és Gazdaságfejlesztési Központ. A Szegedi Tudományegyetemen (továbbiakban: SZTE) belül pedig megkezdte működését a Gazdaság- és Vállalkozásfejlesztési Központ ${ }^{12}$. Bár hazánkban is születtek már külföldi gyakorlatok adaptációjával foglalkozó tanulmányok (Csapó 2007, 2010), illetve történtek már vállalkozásoktatási kutatások is (Mihályi 2001, Szirmai-Csapó 2006), ennek ellenére a téma gyakorlatorientált feldolgozása meglehetősen szerény, a kérdéskör fontosságához képest kevés figyelmet kapott az elmúlt néhány évben. A fejezet célja elsősorban a hazai vállalkozásoktatásnak és a fentebb említett kezdeményezéseknek egyfajta szakmai segítséget nyújtani, amely akár kiindulópontot jelenthet más hazai egyetemek vállalkozásfejlesztési, vállalkozásoktatási gyakorlatának kialakítása során is.

A nemzetközi példák, illetve az adaptálható tényezők áttekintése után a vizsgálódás fókuszában az SZTE-n megvalósítható vállalkozásfejlesztési-, vállalkozásoktatási modell keretének tényezői állnak. Ahhoz, hogy megvizsgáljuk az SZTE és kapcsolódó intézményei (GVK) által nyújtandó szolgáltatásokat, illetve az elvégzendő feladatokat, úgy gondolom, hogy elengedhetetlen a helyi szereplők véleményének megismerése. Éppen ezért primer kutatást végeztem, amely három részre osztható. Egyrészt kérőíves kutatásom során 400 DélAlföld régió megyéiben (Békés, Bács-Kiskun és Csongrád) székhellyel rendelkező tudásintenzív vállalkozást kérdeztem meg arról, hogy milyen tényezők járultak hozzá a vállalkozás elindításához, illetve véleményük szerint az egyetemnek milyen szerepe van a vállalkozás létrehozásában, valamint az egyes kurzusoknak milyen jelentőséget tulajdonítanak a válaszadók.

Másrészt olyan szakértőkkel, illetve vállalkozókkal készítettem szakértői interjúkat, akik nagymértékben hozzájárulhatnak az SZTE vállalkozásfejlesztési-, vállalkozásoktatási modelljének sikerességéhez. Harmadrészt, a kört tovább szűkítve, hallgató korukban

\footnotetext{
${ }^{12}$ A Szegedi Tudományegyetemen működő Gazdaság-és Vállalkozásfejlesztési Központ (GVK) küldetése, hogy közvetlen és közvetett vállalkozásfejlesztési beavatkozásokon keresztül hozzájáruljon a Dél-alföldi régió vállalkozásainak megerősödéséhez és a regionális gazdaság versenyképességének növeléséhez.
} 
vállalkozást indító vállalkozókkal készített mélyinterjúkkal igyekeztem megfelelő alapot biztosítani az SZTE vállalkozásfejlesztési-, vállalkozásoktatási modell keretének.

\subsection{A vállalkozásoktatás és az egyetem lehetséges szerepe a Dél-alföldi régió vállalkozásainak fejlődésében (Kérdőíves kutatás)}

Annak érdekében, hogy megvizsgáljam, hogy a vállalkozások milyen ismereteket tartanak fontosnak a vállalkozásindítás, illetve müködtetés során, valamint hogyan látják az egyetem szerepét, kérdőíves kutatást végeztem. Kutatásom ${ }^{13}$ során elsősorban arra voltam kíváncsi, hogy milyen tényezők járultak hozzá a vállalkozás elindításához, illetve az egyetemnek milyen szerepe van a vállalkozás létrehozásában, az egyes kurzusoknak milyen jelentőséget tulajdonítanak a válaszadók.

A mintát 400 Békés, Csongrád és Bács-Kiskun megyei kis- vagy középvállalkozás alkotta, melynek legalább két foglalkoztatottja van, és legalább két éve müködik. A minta rétegzett minta, nem tekinthető reprezentatívnak, azonban ha kiragadunk egy-egy szempontot, mint például székhely, méret, foglalkoztattak száma, társasági forma, akkor ezen szempontok csoportjai egy-egy véletlen részmintának tekinthetőek, így azok korlátozottan, nagyobb hibahatár mentén összehasonlíthatóak. Az egész mintát egyben kezelve csak leíró statisztikai eljárásokat használhatunk, a részminták mentén próbálok általános következtetéseket is levonni egy adott jelenség különböző csoportok való előfordulásának valószínüségére.

Az első kérdés során azt vizsgáltam, hogy mennyire voltak fontosak az egyes tevékenységek a vállalkozásalapítás során, mekkora fontosságot tulajdonítottak a válaszadók az egyes teendőknek (19. táblázat).

Minden esetben ötfokú Likert-skálán jelölhették meg a válaszadók, hogy mennyire tartották fontosnak az egyes teendőket a vállalkozásuk indítása során (emellett megjelent a „Nem tudom”, „Nem válaszolt kategória”):

1 - Nem használtam a vállalkozásom beindításához.

2 - Kis mértékben használtam a vállalkozásom beindításához.

3 - Részben használtam a vállalkozásom beindításához

4 - Kifejezetten jól jött a vállalkozásom beindításához

\footnotetext{
13 A kutatás a 2012 júniusában zajlott a „Határon átnyúló tanuló régió: egyetemek gazdaságfejlesztési szerepvállalási lehetőségének vizsgálata a magyar-szerb határmenti térségben” címü, HUSRB/1002/213/086 számú Learning Region projekt keretein belül.
} 
19. táblázat: Mennyire voltak fontosak az alábbi teendők a jelenlegi vállalkozás elindításakor?

$(\%)$

\begin{tabular}{|l|l|c|c|c|c|c|c|c|}
\hline & \multicolumn{1}{|c|}{ Tényező } & $\mathbf{1}$ & $\mathbf{2}$ & $\mathbf{3}$ & $\mathbf{4}$ & $\mathbf{5}$ & $\begin{array}{l}\text { Nem } \\
\text { tudja }\end{array}$ & $\begin{array}{c}\text { Nem } \\
\text { válaszolt }\end{array}$ \\
\hline 1. & $\begin{array}{l}\text { Gazdasági, üzleti } \\
\text { képzéseken történő } \\
\text { részvétel }\end{array}$ & 39,75 & 11,50 & 18,25 & 10,25 & 15,75 & 4,50 & 0 \\
\hline 2. & $\begin{array}{l}\text { Szakmai képzéseken } \\
\text { történö részvétel }\end{array}$ & 23,75 & 8,50 & 16,75 & 16,25 & 30,50 & 4,00 & 0,25 \\
\hline 3. & $\begin{array}{l}\text { Szakmai tapasztalatok, } \\
\text { ismeretek begyüjtése }\end{array}$ & 12,00 & 5,25 & 12,00 & 21,00 & 45,50 & 4,00 & 0,25 \\
\hline 4. & $\begin{array}{l}\text { Általánosan elérhető } \\
\text { ismeretek gyüjtése } \\
\text { (könyvek, Internet) }\end{array}$ & 11,75 & 8,25 & 25,50 & 21,00 & 29,00 & 4,25 & 0,25 \\
\hline 5. & $\begin{array}{l}\text { Konzultáció más } \\
\text { vállalkozókkal }\end{array}$ & 22,50 & 10,75 & 21,25 & 19,75 & 21,25 & 4,00 & 0,50 \\
\hline 6. & $\begin{array}{l}\text { Az üzletindítással } \\
\text { kapcsolatos jogi, ügyviteli } \\
\text { ismeretek beszerzése }\end{array}$ & 20,50 & 11,50 & 19,50 & 18,50 & 25,00 & 4,50 & 0,50 \\
\hline 7. & Alaptőke megszerzése & 29,00 & 10,75 & 22,75 & 11,75 & 21,00 & 4,25 & 0,50 \\
\hline 8. & Üzleti terv készítése & 33,00 & 11,25 & 20,50 & 13,25 & 17,00 & 4,25 & 0,75 \\
\hline
\end{tabular}

Forrás: Saját szerkesztés

Ami a leggyakoribb teendőket illeti, a válaszokból kiderült, hogy a vállalkozók kiemelkedő fontosságot tulajdonítanak a szükséges ismeretek, szakmai tapasztalatok összegyüjtésének. A vállalkozásindításhoz elengedhetetlen tevékenységek közül az alábbi három emelkedik ki:

- A megkérdezettek majdnem fele $(45,5 \%)$ a szakmai tapasztalatok, ismeretek összegyüjtését tartják a legfontosabbnak,

- ezt követően a szakmai képzéseken történő részvételt (30,5\%),

- majd az általánosan elérhető ismereteket $(29 \%)$ említik, mint meghatározó tevékenységek.

Ezt követően azt vizsgáltuk, hogy mely tevékenységek azok, amelyeket egyáltalán nem használtak a vállalkozók az indítás során. A visszajelzésekből jól látszik, hogy az alábbi kategóriákat egyáltalán nem tartották fontosnak a megkérdezettek:

- A gazdasági, üzleti képzéseken való részvételt a válaszadók közel 40\%-a egyáltalán nem használta a vállalkozás beindításához

- Az üzleti terv készítését a megkérdezettek 33\%-a nem tartotta fontosnak a vállalkozás alapítása során. 
Összességében a fenti eredmények figyelembevétel a következő alapvető megállapításokat fogalmazhatjuk meg:

- A megkérdezettek egyértelmüen kiemelkedő fontosságot tulajdonítanak a szükséges ismeretek, tapasztalatok megszerzésének a vállalkozásalapítást megelőzően. Ami viszont érdekes, hogy a „Gazdasági, üzleti képzéseken történő részvétel” meglehetősen alacsony szerepet kapott.

- Az eredményekből az is kitünik, hogy alaptőke megszerzése nem jelent érdemi problémát a vállalkozók számára. Emellett az üzleti terv készítésének sem tartottak komolyabb jelentőséget, ami alátámasztja az első kérdésben tapasztalt eredményt, miszerint elsősorban nem új ötletekre épülő vállalkozásokat hoztak létre.

- A vállalkozók programok iránti érdeklődésének hiánya esetlegesen visszavezethető a költségeikre és arra, hogy a vállalkozók nem tudják otthagyni a vállalkozásukat, hogy részt vegyenek az egyes programokon.

A következő kérdéssel az volt a célom, hogy visszajelzést kapjak arról, hogy a vállalkozók hogyan vélekednek az Egyetemröl ${ }^{14}$, illetve az Egyetem vállalkozásindításban betöltött szerepéröl.

A 20. táblázat tartalmazza kérdőívem állításait, valamint a válaszadók értékeléseit. Jól látszik, hogy kiemelkedő értékekkel szinte egyáltalán nem találkozunk, csupán egyetlen esetben (,,Az egyetemen kialakulnak olyan barátságok, személyes kapcsolatok, melyek jelentősen támogatják egy vállalkozás elindítását, üzletmenetének folytatását.”) jelenik meg egy kiugró eredmény. Ebben az esetben a vállalkozók 42,75\%-a gondolja úgy, hogy az egyetemi barátságok, kapcsolatok meghatározó jelentőségűek. Talán még az egyetem kreatív légkörét, illetve vezetői készségek fejlesztésében játszott szerepét ismerik el a vállalkozók, az előbbivel 23,25\%, míg az utóbbival 24,25\%-ban értenek egyet a válaszadók.

A többi esettel kapcsolatosan elmondható, hogy meglehetősen egyenletesen oszlanak el a válaszok az öt kategória között. Érdekes, hogy az utolsó két kategória esetében, ahol az egyetem befektetők megszerzésében betöltött szerepére, illetve új vállalkozások létrehozásának támogatására kérdeztünk rá leginkább „nem tudom” válaszok születtek.

\footnotetext{
14 Az Egyetem itt általánosságban mint felsőoktatási intézmény jelenik meg, nem konkrétan a Szegedi Tudományegyetemről van szó, hiszen a válaszadókat nem szürtem az alapján, hogy hol végezték tanulmányaikat.
} 
20. táblázat: Az egyetem szerepével kapcsolatos megállapításokra adott válaszok megoszlása $(\%)$

\begin{tabular}{|c|c|c|c|c|c|c|c|c|}
\hline & Tényező & $\mathbf{1}$ & 2 & 3 & 4 & 5 & $\begin{array}{l}\text { Nem } \\
\text { tudja }\end{array}$ & $\begin{array}{c}\text { Nem } \\
\text { válaszolt }\end{array}$ \\
\hline 1. & $\begin{array}{l}\text { „A egyetem kreatív légköre } \\
\text { inspirálja az új vállalkozások } \\
\text { ötleteinek kialakítását.” }\end{array}$ & 14,75 & 5,75 & 17,25 & 14,75 & 23,25 & 22,00 & 2,25 \\
\hline 2. & $\begin{array}{l}\text { „A kurzusok fejlesztik a társadalmi } \\
\text { és vezetői készségeket, amelyek } \\
\text { szükségesek a vállalkozók } \\
\text { számára.” }\end{array}$ & 9,25 & 9,75 & 19,00 & 17,25 & 24,25 & 18,25 & 2,25 \\
\hline 3. & $\begin{array}{l}\text { „A kurzusok biztosítják azt a } \\
\text { tudást, amely szükséges egy új cég } \\
\text { elindításához.” }\end{array}$ & 12,75 & 12,75 & 25,5 & 13,25 & 13,50 & 19,75 & 2,50 \\
\hline 4. & $\begin{array}{l}\text { „Az egyetemen kialakulnak olyan } \\
\text { barátságok, személyes kapcsolatok, } \\
\text { melyek jelentősen támogatják egy } \\
\text { vállalkozás elindítását, } \\
\text { üzletmenetének folytatását.” }\end{array}$ & 4.50 & 2,75 & 12,25 & 21,5 & 42,75 & 14,00 & 2,25 \\
\hline 5. & $\begin{array}{l}\text { „Az egyetem segítséget nyújt } \\
\text { befektetők megszerzéséhez.” }\end{array}$ & 21,75 & 16,00 & 18,5 & 5,75 & 5,00 & 30,50 & 2,50 \\
\hline 6. & $\begin{array}{l}\text { „Az egyetem aktívan támogatja az } \\
\text { új cég megalapításának } \\
\text { folyamatát." }\end{array}$ & 24,75 & 15,00 & 13,00 & 6,00 & 5,25 & 37,00 & 2,25 \\
\hline
\end{tabular}

Forrás: Saját szerkesztés

A 20. táblázatból is látszik, hogy a 4. válasznak messze nagyobb fontosságot tulajdonítottak a megkérdezettek, mint a többinek. Emellett a kutatásom szempontjából nem túl kedvező eredmény, hogy az egyetem vállalkozásalapításban játszott szerepét a legutolsó helyre sorolták a vállalkozók. Ezzel a kérdéssel elsősorban azt a feltételezésemet szerettem volna megvizsgálni, miszerint az egyetemnek fontos szerepe van a vállalkozásalapítás elősegítésében, segítséget nyújthat a vállalkozóknak a vállalkozásindításban. Azonban a válaszok elemzése során azt tapasztaltam, hogy egyelöre nem figyelhető meg az ún. vállalkozó egyetem jelensége, hiszen a válaszadók visszajelzései alapján arra a következtetésre jutottunk, hogy az egyetem vállalkozásfejlesztés szerepe a vállalkozók gondolkodásában még nincs jelen. Egyelőre az egyetem csupán a kapcsolatok kiépítésében játszik meghatározó szerepet.

A harmadik kérdés során arra voltam kíváncsi, hogy a vállalkozók mely ismeretek tartják fontosnak a vállalkozásindítás szempontjából. Az előző kérdéshez kapcsolódóan itt is kísérletet tettem arra, hogy elemezzem az egyetem milyen szerepet tölt be a vállalkozásindításban. A vállalkozásoktatás elősegítheti a vállalkozói és innovatív kultúra kialakítását a gondolkodásmód megváltoztatásával és a szükséges készségek biztosításával. 
21. táblázat: Az egyes ismereteknek tulajdonított fontosság megoszlása (\%)

\begin{tabular}{|c|c|c|c|c|c|c|c|c|}
\hline & Ismeret típusok & $\mathbf{1}$ & $\mathbf{2}$ & $\mathbf{3}$ & $\mathbf{4}$ & $\mathbf{5}$ & $\begin{array}{c}\text { Nem } \\
\text { tudja }\end{array}$ & $\begin{array}{c}\text { Nem } \\
\text { válaszolt }\end{array}$ \\
\hline 1. & Vállalkozói ismeretek & 0,75 & 2,50 & 11,25 & 27,25 & 57,75 & 0,50 & 0,00 \\
\hline 2. & Marketing ismeretek & 1,75 & 4,50 & 21,00 & 31,00 & 41,50 & 0,25 & 0,00 \\
\hline 3. & Pénzügyi ismeretek & 0,75 & 3,25 & 14,25 & 30,75 & 51,00 & 0,00 & 0,00 \\
\hline 4. & $\begin{array}{c}\text { Üzleti terv készítésének } \\
\text { ismerete }\end{array}$ & 6,75 & 7,75 & 25,25 & 28,50 & 31,50 & 0,25 & 0,00 \\
\hline 5. & $\begin{array}{c}\text { Innováció menedzsment } \\
\text { ismeretek }\end{array}$ & 4,50 & 8,50 & 28,25 & 33,00 & 23,75 & 2,00 & 0,00 \\
\hline 6. & $\begin{array}{c}\text { Pályázatírás és } \\
\text { projektmenedzsment } \\
\text { ismeretek }\end{array}$ & 11,25 & 10,00 & 29,00 & 24,25 & 24,50 & 1,00 & 0,00 \\
\hline
\end{tabular}

Forrás: Saját szerkesztés

A 21. táblázatból az alábbi eredményeket emelhetjük ki:

- A megkérdezettek 57,75\%-a a várakozásoknak megfelelően a vállalkozói ismereteket tartja a legfontosabbnak.

- Ezt követi a pénzügyi ismeretek 51\%-kal, illetve a marketing ismeretek 41,5\%-kal.

- A maradék három ismeretnek (üzleti terv készítése, innováció menedzsment, illetve pályázatírás) egyaránt kisebb fontosságot tulajdonítanak a vállalkozók.

A negyedik kérdéssel azt szerettem volna megvizsgálni, hogy a vállalkozók az egyes ismeretekre milyen hangsúlyt fektetnek, illetve fektettek a vállalkozás sikeres müködése érdekében.

22. táblázat: Az egyes ismeretekre fektetett hangsúly megoszlása (\%)

\begin{tabular}{|l|c|c|c|c|c|}
\hline \multicolumn{1}{|c|}{ Válaszlehetőségek } & $\begin{array}{c}\text { Múltban } \\
\text { fejlesztettük, de } \\
\text { már nem } \\
\text { fogjuk }\end{array}$ & $\begin{array}{c}\text { Folya- } \\
\text { matosan } \\
\text { fejleszt- } \\
\text { jük }\end{array}$ & $\begin{array}{c}\text { Eddig nem } \\
\text { fejlesz- } \\
\text { tettük, de a } \\
\text { jövöben } \\
\text { fogjuk }\end{array}$ & $\begin{array}{c}\text { Nem } \\
\text { tudja }\end{array}$ & $\begin{array}{c}\text { Nem } \\
\text { válaszolt }\end{array}$ \\
\hline Kereskedelmi jog & 23,75 & 27,25 & 7,25 & 32,00 & 9,75 \\
\hline $\begin{array}{l}\text { Vállalkozásfejlesztési } \\
\text { lehetőségek (kisvállalatok } \\
\text { támogatása) }\end{array}$ & 18,75 & 45,25 & 10,75 & 21,00 & 4,25 \\
\hline Üzleti tervezés & 18,25 & 56,50 & 6,50 & 14,00 & 4,75 \\
\hline $\begin{array}{l}\text { Saját piac (szerkezet, trendek } \\
\text { stb.) ismeretek }\end{array}$ & 10,50 & 75,75 & 3,75 & 8,25 & 1,75 \\
\hline Marketing & 22,50 & 50,75 & 6,50 & 15,25 & 5,00 \\
\hline $\begin{array}{l}\text { Humáneröforrás és } \\
\text { foglalkoztatási ügyek }\end{array}$ & 25,75 & 36,00 & 6,50 & 26,50 & 5,25 \\
\hline Csapatépítés és fejlesztés & 25,50 & 33,25 & 7,00 & 27,00 & 7,25 \\
\hline Pénzügyi menedzsment & 16,25 & 51,50 & 3,75 & 24,00 & 4,50 \\
\hline $\begin{array}{l}\text { Finanszírozási lehetóség } \\
\text { megtalálása és megszerzése }\end{array}$ & 17,75 & 51,75 & 9,25 & 16,50 & 4,75 \\
\hline
\end{tabular}

Forrás: Saját szerkesztés 
Ennél a kérdésnél kiemelném, hogy a válaszadók nagy része $(75,75 \%)$ a várakozásoknak megfelelően a saját piacuk ismeretét folyamatosan fejlesztik, ami nyilván elengedhetetlen egy vállalkozás sikeres müködtetéséhez. Egy érdekesség, hogy az üzleti tervezést szintén ebben a kategóriában szerepel a vállalkozók 56,5\%-nál, miközben a korábbiakban úgy tünt, hogy nem különösebben tartották fontosnak a vállalkozás elindításakor, azonban a müködtetés során az eredmények szerint már igen fontos tényező.

A folyamatosan fejlesztendő kategóriában ezt követően a finanszírozási lehetőségek megtalálása $(51,75 \%)$, a pénzügyi menedzsment $(51,5 \%)$, valamint a marketing $(50,75 \%)$ emelkedik ki. A jövőre vonatkozó kérdésnél érdekes módon egyik kategóriát sem jelölték meg meghatározó mértékben.

Jelen kutatással érzékeltetni szerettem volna, hogy mely tényezők vezetnek, illetve vezettek vállalkozások alapításához, valamint mik járulnak hozzá a sikeres müködéshez. Az eredményekből jól látszik, hogy a válaszadók rendkívül nagy fontosságot tulajdonítanak a vállalkozás előtti felkészülésnek, különösen a megszerzendő ismereteknek. Továbbá kiemelnénk a képzések jelentőségét, amely vélelmezhető, hogy a felsőoktatásban megszerzett vállalkozói és üzletviteli ismeretek egyrészt megalapozottabb és jobban előkészített vállalkozások megindítását segítik elő, másrészt a napi operatív működetést is jelentős mértékben megkönnyíthetik. Azonban az egyetemek vállalkozásalapításban betöltött szerepét meglehetősen vizsgálva az eredmények azt mutatják, hogy a vállalkozók úgy érzik az egyetem egyelőre nem nyújt segítséget a vállalkozások indításában.

Az empirikus vizsgálat eredményei egyértelmüen mutatják azt, hogy a dél-alföldi régióban olyan szűk keresztmetszetek rajzolódnak ki, amelyek nem teszik lehetővé, hogy nemzetközileg sikeres, hatékonyan müködő vállalkozások kritikus tömege legyen jelen a térségben. Ezen kihívásokra tudatos, jól menedzselt választ kell adni, mely jól megfontolt stratégián kell, hogy alapuljon. A továbbiakban ezen stratégia alapköveivel kapcsolatosan kívánjuk két fontos megállapítást lehet tenni az egyetem szerepvállalásával kapcsolatosan.

Egyik a szemléletformálás, melynek fontos tényezője maga a vállalkozásoktatás. Ezen belül fontos a célcsoport elérése, szegmentálása, kiemelt fókusz az innovatív vállalkozások alapítására képes egyetemi polgárokra. A szemléletformáláson belül lenne egyetemen belüli, majd egyetemen kívüli szemléletformálás. Jelen esetben a vállalkozásoktatás két legfontosabb célcsoportja egyértelmüen a hallgatók, illetve a régióban meglévő, avagy potenciális 
vállalkozók. Az első esetet tovább szűkítve a vállalkozói attitüdformálása mellett a vállalkozókészségekkel rendelkező, potenciálisan tudásintenzív vállalkozásalapításban gondolkodó hallgatók segítése kiemelkedő jelentőséggel bír. A helyben megtermelt tudás hasznosításának elősegítése nagyon fontos, hiszen a különböző karokon létrejött tudás megfelelő vállalkozásoktatással lokálisan hasznosulhat. A második célcsoport esetében pedig akár egyetemről kipörgő spin-off vállalkozásokról, akár egyéb tudásintenzív vállalkozásokról legyen szó mindenképpen szükség van a vállalkozás müködtetésében, hovatovább fejlődésében (mint például kockázati tőkések megtalálásában, számukra megfelelő üzleti terv készítésében) segítséget nyújtani ahhoz, hogy kiaknázzák a bennük rejlő lehetőségeket.

Mind a szakirodalom, mind a kutatás eredményei egyértelműen alátámasztják, hogy szükség van magas színvonalú vállalkozásoktatásra a térségben. Mindehhez az SZTE megfelelő infrastruktúrát tud biztosítani. Éppen ezért a következő irány az üzleti infrastruktúra fejlesztés, melynek keretén belül végiggondolásra érdemes egy egyetemi inkubátorház, illetve science park kialakítása. A lokális innovatív vállalkozások számára mindkét esetben minőségi szolgáltatásokat kellene nyújtani. Egy science park térségi innovációs hatása kiemelkedő, amelynek bázisát egyrészt a konkrét fejlesztés, másrészt a Szegedi Tudományegyetem, harmadrészt a térség további kutatóhelyei (SZBK, BayBio) jelentik. Ehhez szervesen kapcsolódnak középtávon a már meglévő, illetve a térségbe jövőben betelepülő innovatív vállalkozások. Azonban ahhoz, hogy ezek a vállalkozások sikeresek legyenek szükség van a jól képzett munkaerőre és megfelelő vállalkozói kompetenciákkal rendelkező vállalkozókra, amiben az SZTE egyértelmüen segítséget tud nyújtani. A vállalkozásoktatás, a vállalkozóvá válás tudatos elősegítésének és inspiratív, müködést segítő üzleti környezet kialakításának keretein belül a science park célja lehet a park kutatói, szakemberei részére magas szintű vállalkozásoktatás biztosítása annak érdekében, hogy a meglévő tudást üzleti alapokra helyezze és nagy növekedési potenciállal rendelkező spin-off vállalkozások jöjjenek létre. Ennek érdekében a Szegedi Tudományegyetem vállalkozói és üzleti oktatást biztosíthatna a gazdasági végzettséggel nem rendelkező szereplők számára.

Ehhez szorosan kapcsolódva egyértelmüen szükséges a spin-off és start-up vállalkozások számára speciális üzletfejlesztési szolgáltatások kialakítása. A vállalkozóvá válást elősegítő vállalkozói és üzleti oktatás mellett kiemelkedő fontossággal bírnak a speciális üzletfejlesztési szolgáltatások (tanácsadás, mentorprogramok, korai növekedés menedzselése), amelyek mind a vállalkozásalapítás, mind a működés során hozzájárulnak a hosszú távú 
sikerességhez. Egy ilyen jellegü koncentráció mellett hosszabb távon érdemes egy tudásintenzív vállalkozásokra specializált tanácsadói háttér kialakítása - pontosan a piaci hasznosítás érdekében.

A fentiekkel kapcsolatban elmondhatjuk, hogy a vállalkozó egyetemen belül a vállalkozásoktatás alapfunkcióvá válik, hiszen ezzel tudják megteremteni a nagy növekedési potenciállal bíró tudásintenzív vállalkozások kritikus tömegét mind a vállalkozásalapítási hajlandóság növelésén keresztül, mind pedig a magasabb vállalkozási fennmaradási rátán keresztül. Ezen túlmenően megfelelő üzleti infrastruktúra és science park kialakítása szorosan kapcsolódik a vállalkozásoktatás outputjához azáltal, hogy az ily módon már felkészített innovatív vállalkozásoknak megfelelő teret biztosít a további fejlödéshez, illetve közvetve hozzájárul a gazdaság versenyképességének növeléséhez.

\subsection{SZTE lehetséges szerepe a hallgatók vállalkozóvá válásának elősegítésében (Szakértői interjúk)}

Az SZTE-n belül 12 karon folyik képzés, az egyetem hallgatóinak létszáma hozzávetőlegesen 30.000 fő. Az SZTE többlépcsős képzési portfoliót tudhat magáénak, melynek elemei: a felsőfokú szakképzés, BA/BSc képzés, MA/Msc képzés, valamint a doktori képzés (19 doktori iskolában). Pontosan ez a multidiszciplinaritás jelent igen komoly bázist a potenciális tudásintenzív spin-off cégek létrejöttéhez, következésképp a színvonalas vállalkozásoktatás gyakorlat kialakítása egy lehetséges kitörési pont. Ezen túlmenően igen reménykeltő az a tény is, hogy az SZTE nappali tagozatos hallgatói körében a korai fázisú vállalkozói aktivitás jelentősen meghaladja a teljes lakosságra vonatkozó hazai átlagot (Imreh-Tóth et al. 2013). Éppen ezért primer kutatásom második részében igyekeztem feltérképezni az SZTE szerepét a hallgatók vállalkozóvá válásának elősegítésében. Továbbá, ahogy Lengyel (2012) is megfogalmazta „az egyetemek által a helyi gazdaságra gyakorolt hatás területileg koncentrált, az agglomerációs externhatások és tudástúlcsordulás hatásai az egyetemi városokra és azok munkaerö-vonzáskörzetére korlátozódnak” (Lengyel 2012, 42. o.). Mindez megerősített abban az elképzelésemben, hogy SZTE közeli szakértőket kérdezzem meg.

Kvalitatív kutatásom folytatásában szakértői interjúk segítségével próbáltam szűkíteni és pontosítani az SZTE vállalkozásfejlesztési-, vállalkozásoktatási modelljének kereteit. Az interjúalanyok számának megválasztásánál azzal a kitétellel éltem, hogy addig vonok be 
újabb alanyokat, ameddig többletinformáció még kinyerhető, így jutottam el 12 föig, mert 10 főtől kezdve már nem kaptam „újabb” információt. Az interjúalanyok kiválasztása során a legfontosabb célom az volt, hogy helyi szinten, a vállalkozóvá válás területén meghatározó szereplőket kérdezzek meg vállalkozásfejlesztéssel, vállalkozásoktatással kapcsolatosan. Ennek megfelelően a következő kérdésekre kerestem a választ:

\section{Vállalkozásfejlesztés}

1. Az SZTE hogyan tudná segíteni hatékonyan és eredményesen a hallgatók vállalkozóvá válását?

2. Ha erre létrejön egy elkülönült szervezeti egység, véleménye szerint milyen feladatai lennének?

3. A fentiek érdekében milyen konkrét szolgáltatásokat nyújtson a GVK és milyen célcsoportoknak?

4. Ismer-e esetleg más felsőfokú intézményeknél olyan jó gyakorlatot, amelyet lehet adaptálni a GVK müködésére?

\section{Vállalkozásoktatás}

5. A vállalkozásoktatáson belül Ön szerint milyen kompetenciákat kellene fejleszteni?

6. A vállalkozásoktatáson belül a tényleges hatékony vállalkozóvá válás érdekében milyen ismereteket érdemes oktatni?

7. Milyen oktatás-módszertani hátteret tartana a legeredményesebbnek a fentiek érdekében?

A szakértői interjúkon alapuló kvalitatív kutatásom kettős céllal készült. Egyrészt a nemzetközi példák megismerése, illetve az általam átvehetőnek, adaptálhatónak vélt gyakorlatok kiszürése után, helyi szinten is megvizsgáljam, hogy a lokális szakértők, tudásintenzív vállalkozók milyen lehetőségeket, illetve milyen esetleges további feladatokat képzelnek el az SZTE vállalkozásfejlesztési-, vállalkozásoktatási modelljével kapcsolatosan.

Másrészt célom volt, hogy a nemzetközi (amerikai, európai) és helyi szinten összegyüjtött eredmények, közös pontok alapján körvonalazzam, valamint (lehetőségeimhez mérten) konkrét tevékenységekkel töltsem fel az SZTE vállalkozásfejlesztési-, vállalkozásoktatási modelljét. 


\subsubsection{Az interjúalanyok bemutatása}

Az interjúalanyok kiválasztása során arra törekedtem, hogy olyan szakértőket és/vagy tudásintenzív vállalkozókat kérdezzek meg, akik

1. a vállalkozásfejlesztés-vállalkozásoktatás valamely aspektusával kapcsolatosan releváns tudással rendelkeznek,

2. valamilyen módon kapcsolódnak az SZTE-hez, illetve

3. valamilyen módon kapcsolódnak a vállalkozásoktatás outputjához.

Az interjúalanyok nevesítése csak a 23. táblázat erejéig történik meg, az elemzés során 1-12ig megjelölt interjúalanyokra hivatkozok, de ez a sorrend nem feleltethető meg a táblázatban megjelenő sorrendnek.

23. táblázat: Az interjúalanyok bemutatása

\begin{tabular}{|c|c|c|}
\hline Interjúalany & Beosztás & Munkahely \\
\hline Balogh Péter & Gazdasági igazgató & Lavina Foundation / Alapítvány \\
\hline Bucsai Kálmán & Operatív igazgató & LC Innoconsult International \\
\hline Dr. Buzás Norbert & $\begin{array}{l}\text { Kutatás-fejlesztés és innovációs } \\
\text { igazgató }\end{array}$ & $\begin{array}{l}\text { Szegedi Tudományegyetem } \\
\text { Kutatás-fejlesztési és } \\
\text { Innovációs Igazgatóság }\end{array}$ \\
\hline Hajdú Szabolcs & $\begin{array}{l}\text { Alapító, senior tanácsadó } \\
\text { Pénzügyi igazgató }\end{array}$ & $\begin{array}{l}\text { Qualinnova Consulting Kft. } \\
\text { SOLVO Biotechnológiai Zrt. }\end{array}$ \\
\hline Dr. Imreh Szabolcs & Egyetemi docens & $\begin{array}{l}\text { Szegedi Tudományegyetem } \\
\text { Gazdaságtudományi Kar }\end{array}$ \\
\hline Dr. Kiss István & Intézetigazgató (BAY-BIO) & $\begin{array}{l}\text { Bay Zoltán Alkalmazott } \\
\text { Kutatási Közhasznú Nonprofit } \\
\text { Kft. }\end{array}$ \\
\hline Dr. Kosztopulosz Andreász & Egyetemi docens & $\begin{array}{l}\text { Szegedi Tudományegyetem } \\
\text { Gazdaságtudományi Kar }\end{array}$ \\
\hline Dr. Lukovics Miklós & $\begin{array}{l}\text { Egyetemi docens } \\
\text { Stratégiai és fejlesztési igazgató }\end{array}$ & $\begin{array}{l}\text { Szegedi Tudományegyetem } \\
\text { Gazdaságtudományi Kar } \\
\text { Szegedi Tudományegyetem } \\
\text { Stratégiai és Fejlesztési } \\
\text { Igazgatóság }\end{array}$ \\
\hline Dr. Makra Zsolt & Ügyvezető igazgató & $\begin{array}{l}\text { Ayudate Holding Tanácsadó } \\
\text { Kft. }\end{array}$ \\
\hline Dr. Mogyorósi Péter & $\begin{array}{l}\text { Ügyvezető igazgató, alapító } \\
\text { tulajdonos }\end{array}$ & LC Innoconsult International \\
\hline Dr. Prónay Szabolcs & Adjunktus & $\begin{array}{l}\text { Szegedi Tudományegyetem } \\
\text { Gazdaságtudományi Kar }\end{array}$ \\
\hline Dr. Vilmányi Márton & Dékán & $\begin{array}{l}\text { Szegedi Tudományegyetem } \\
\text { Gazdaságtudományi Kar }\end{array}$ \\
\hline
\end{tabular}

Forrás: Saját szerkesztés 


\subsubsection{Szakértői interjúkból adódó megállapítások}

Az alábbiakban összefoglalom a kvalitatív kutatásom legfontosabb eredményeit mindvégig az interjú vezérfonala mentén haladva. Az egyes részeknél - ahol lehetőség nyílik rá - kiemelem azon pontokat, amelyeket legtöbben említenek (ismétlődő motívumokat keresve), majd a válaszok alapján a kérdésnek megfelelően rendszerezem és szintetizálom a legfontosabb eredményeket.

\section{Az SZTE hogyan tudná segíteni hatékonyan és eredményesen a hallgatók vállalkozóvá válását?}

Mielőtt a válaszok elemzésébe részletekbe menően belefognék meg kell jegyezzem, hogy a válaszadók döntő többségének az volt az első kérdése/gondolata, hogy „miért van az SZTE 20 évvel elmaradva, és miért nem segít a vállalkozóvá válásban?” Annak ellenére van ez így, hogy az SZTE-n minden szükséges kompetencia rendelkezésre áll, mégsem tesznek lépéseket a vállalkozóvá válás ösztönzésében.

A válaszadók számos területen látják az SZTE „beavatkozási lehetőségeit”, ezek közül a következők minden esetben megjelentek:

- Gyakorlati oktatás

- Vállalkozói klubok, rendezvények

- Versenyek (üzleti terv versenyek, startup weekendek, startup konferenciák szervezése)

- „Vállalkozói”alumni erősítése

A gyakorlati oktatás szükségessége volt az, amit minden válaszadó először kiemelt. Ezzel kapcsolatban a második interjúalany szerint

„az SZTE formális oktatás keretein belül vállalkozásindításhoz kapcsolódó tantárgyakkal tudná segíteni a vállalkozóvá válást. Ilyen tantárgyak már jelenleg is futnak szabadon választható kurzusként, azonban mérsékelt érdeklödéssel. A 3-4 különálló kurzus (marketing, menedzsment, pénzügy, jog) helyett egyetlen kurzusba kellene tömöríteni az anyagot, mely célirányosan csak a vállalkozás megalapításához szükséges gyakorlati lépéseket takarná, heti 2 kontaktórás terjedelemben, több oktató által közösen oktatottan. 2-2 duplaórában az alábbi ismeretek átadásával: Vállalkozásalapítás jogi lépései, technikai lebonyolításának menete az aktuális 
jogszabályok szerint; Üzleti terv készités (célja, fajtái; menete); Környezetelemzés, versenytárselemzés (menete, lépései, szempontjai, technikái); Pénzügyi tervezés, cashflow tervezés (excellel gyakorlati példán át vezetve, minimális matematikai kitérövel); Marketing kommunikációs eszközök megismerése. „A tantárgyat kötelezöen választható tárggyá tenni, kifejezetten magas kreditszám és szigorú követelményrendszer mellett több karon.”

A negyedik interjúalany ennél sokkal élesebben fogalmaz, szerinte a világ vezető egyetemein számtalan olyan eszköz van, amit adaptálhatnánk, azonban forráshiányra hivatkozva mindez nem történik meg.

„Azonban itt nem a forrás hiányzik, hanem a lelkesedés. A képzésekkel az a baj, hogy vak vezet világtalant, nagyrészt olyan emberek tanítanak, akik a vállalkozási ismereteket tankönyvböl sajátították el. Vannak olyanok, akiknek van vállalkozásuk, illetve olyanok is, akik habitusuknál fogva megtanulják tankönyvekböl, de úgy tudják elmondani, mintha valóban müvelnék és nagyon meggyözö.”

Ezek után megfogalmazza, hogy ahhoz, hogy valóban eredményes oktatás valósuljon meg az alábbiakra lenne szükség:

- „Olyan embereknek kell tanítani azt, hogy hogyan kell kezelni a minden napi problémákat, akik ezt meg is élik. Lehetöség szerint nem is egy vállalkozásban, hanem több cégben.

- Olyan struktúrákat kell kialakítani, ahol a hallgatók saját maguk kipróbálhatják, hogy milyen vállalkozóvá válni, aztán esetenként ebbe bele is bukhatnak.

- Elintézni, hogy a hallgatók a vállalkozásoknál valódi munkát végezzenek (szemben a kávékészítéssel). Így például a hallgató elmegy egy klaszterbe, ahol van 10 hasonló vállalkozás és a klaszterben 3 különbözö vállalatnál dolgozik, mindegyiknél 2-3 hónapot.

- Az egyetem feladata, hogy olyan vállalkozások jöjjenek létre, erösödjenek meg, amelyeknek köze van az egyetemhez. A tudásalapú vállalkozások megteremtéséhez és növekedéséhez szükséges inputokat kell átadni.”

A második terület a nemzetközi vizsgálatoknál is kiemelkedő helyet elfoglaló informális klubok és rendezvényeik támogatása, népszerüsítése, ahol gyakorlati vállalkozó szakemberek pozitív példaként állnak a fiatalok elé. 
A tizedik interjúalany szerint:

„az egyik legfontosabb feladat vállalkozó-hallgató kapcsolatok erösítése minden lehetséges területen. Ennek a kluboktól kezdve a különféle informális találkozókon át a „hazatérést elösegíto"” programokig mindenhol meg lehet találni a helyét. Kevés hasznosabb terület van mint az, ha hallgatók minél kötetlenebb módon beszélgethetnek valódi vállalkozóktól. Itt a konkrét ötletektől az üzletviteli kérdésekig bármi elökerülhet. Tehát azon felül,, hogy találkoznak „élő vállalkozókkal”, még közvetlen szakmai hozadékai is lehetnek a dolognak"

A harmadik terület a versenyek, konferenciák szervezése. Az első interjúalany vállalkozói/ötlet versenyek szervezését javasolja, amely keretein belül a hallgatók előállnak az ötleteikkel, egy szakmai bizottság előtt mindezt prezentálják és a legjobb ötletekre - az SZTE mentorálása mellet - alakítanak egy céget.

A negyedik terület, a vállalkozói alumni erősítése, alumni program indítása az egyetemről kikerült sikeres vállalkozók beszervezésével. A második interjúalany szerint

„a Karrier Iroda és az Alma Mater közremüködésével a potenciális munkaerö megtalálásában való közremüködés a már beindult vállalkozás számára szintén nagy fontos tényezö."

Az említett négy „közös”, legtöbb megkérdezett által említett területen túlmenően a következőkben látják a válaszadók az SZTE feladatát:

- hallgatói tanulmányutak szervezése hazai és külföldi vállalkozásokhoz, startup központokba,

- mentorprogram elindítása,

- egy egyetemi inkubátor müködtetése,

- tőkealap létrehozása, mely hallgatói vállalkozásokba fektethet tőkét

- a közvetítés felvállalása a befektetők és a vállalkozók között

- hallgatói pályázatok elkészítéséhez és lebonyolításához nyújtott segítség

- vállalkozóvá válást segítő honlap, kiadványok létrehozása

- vállalkozói központok müködtetése, tanácsadás, esetleg spin-off alapítás

A fentieken túl kiemelném az ötödik interjúalany igen elgondolkodtató felvetését, miszerint „elsö lépésben az SZTE feladata az, hogy a fejekben tisztázza, hogy a vállalkozóknak van felelössége. Önmagában az elméletet a hallgatók nem mindig tudják mihez kötni.” 
Ehhez kapcsolódik a hatodik interjúalany véleménye is, azaz „az SZTE-n oktató szakembereknek kellene egy attitüdöt szolgáltatni a hallgatóknak."

A nyolcadik interjúalany hozzáteszi, hogy a keresletet is generálni kell az ilyen típusú tudásra (hallgatók vállalkozóvá válása) és ehhez kell meghatározni a kínálatot. Azaz (az ötletekkel rendelkező) hallgatókban fel kellene gerjeszteni az igényt arra, hogy vállalkozóvá váljanak. Ebben az esetben mind a keresleti, mind a kínálati oldalon az SZTE-nek nagyon nagy szerepe van.

A kilencedik válaszadó szerint a megfelelő célcsoport elérésével, illetve a szükséges finanszírozás biztosítása mellett nem gazdász (TTIK, ÁOK) és közgazdász hallgatók „összekapcsolásával” lehetne hatékony eredményeket elérni a vállalkozóvá válás terén.

A tizenegyedik interjúalany szerint az SZTE elsődlegesen a megfelelő ismereteket, attitüdformálást, a társas kapcsolati hálót (hallgató-hallgató és hallgató-vállalkozó tekintetében), valamint az infrastruktúrát tudja biztosítani a hallgatók számára. Ez utóbbin belül a rendelkezésre álló irodahelyiségeken túl a Szegedről elérhető hitelek, tőke elérhetőségében történő segítségnyújtás nagyon fontos. Továbbá, az SZTE-nek nagy szerepe van a tapasztalatszerzés lehetőségének megteremtésében.

\section{Ha erre létrejön egy elkülönült szervezeti egység, véleménye szerint milyen feladatai lennének?}

Ebben az esetben számos eltérő feladatot soroltak fel az interjúalanyok, amelyeket általános rendezőelv mentén a következőképpen lehet csoportosítani.

Az egyik lehetséges feladatkör a vállalkozói attitüd formálása, a vállalkozóvá válás mint lehetséges jövőkép bemutatása a hallhatóknak kutatóknak, míg a másik része a lehetséges tevékenységeknek a konkrét szolgáltatások nyújtása. Értelemszerüen a két szerepkör bizonyos feladatok esetében nem válik el mindig markánsan.

Az attitüd kialakításával és megerösítésével kapcsolatos leggyakrabban megjelenö gondolatok az alábbiak:

- Klub jellegü rendezvények szervezése, ahol vállalkozók beszélnek erről az életformáról.

- Workshopok szervezése a vállalkozási sikeresség növekedésére. 
- Vállalkozói létforma és a vállalkozói tudat népszerüsítése a hallgatók körében.

- Későbbiekben akár inkubációs intézménnyé (de nem inkubációs házzá, sokkal inkább open platform jellegü munkaállomássá) való növekedés.

- Nyílt napok szervezése, ahol a hallgatók megismerhetnek pár sikeres és sikertelen (!) vállalkozás történetet.

Vállalkozásalapításhoz, és müködtetéshez kapcsolódó feladatok:

- Mentorálás.

- Legjobb gyakorlatok összegyüjtése és megismertetése a hallgatókkal.

- Tanácsadás, egyablakos módszerrel (pályázati tanácsadástól üzletviteli tanácsadásig).

- Vállalkozás alapításához kapcsolódó segédanyagok, tájékoztató füzetek gyártása.

- Lehetőség biztosítása ahhoz, hogy megvizsgálják, hogy az adott személy mennyire alkalmas arra, hogy vállalkozó legyen.

- Kezdő, innovatív vállalkozások számára forráskeresés, forrásfelhasználás koordinálása.

- Jogi, IPR, marketing stb. szolgáltatás biztosítása.

• „Vállalkozásfejlesztési szervező-koordináló munka a-tól z-ig”.

Érdekes egyéb feladatot fogalmaz meg a tizedik interjúalany:

„a nulladik lépés mindenekelött az eddig már létrejött kezdeményezések szintetizálása, a meglévö aktivitások kataszterének elkészítése lehetne a Központ számára. Nem igazán tudja senki, hogy az elmúlt néhány évben milyen szigetszerü, elkülönült kezdeményezések indultak el, illetve milyen tapasztalatok gyültek fel. Abban biztos vagyok, hogy nem nulláról kell indulni, elegendö csak a GTK-s vonalra gondolni, az Innovációs Igazgatóság tevékenységére, vagy akár az Universitas NKft vállalkozói projektjeire. Elöször ezeket kellene összeszedni, kategorizálni, azaz azt, hogy mit tudunk és mit nem. Csak a fentiek után jönnének a továbbfejlesztési lehetöségek vizsgálata, a legjobb gyakorlatok adaptálási lehetöségeinek feltérképezése. Majd ezt követheti a tényleges szakmai háttér kialakítása”

Ezzel összhangban a harmadik interjúalany úgy látja, hogy

„célszerü lenne erre az elkülönült szervezeti egységre telepíteni az összes olyan funkciót, ami az egyetemi vállalkozásösztönzést szolgálja (centralizált modell).” 
A negyedik interjúalany szerint nagyon fontos, hogy konstans utánpótlást tudjon produkálni az SZTE a startup, spin-off cégek élére, hiszen ez egyelőre nem alakult ki, nincs megfelelő vezetői réteg kiképezve.

A hatodik interjúalany egy nagyon érdekes és fontos megjegyzést tett a vállalkozóknak nyújtott szolgáltatások kialakításával kapcsolatosan:

„...ahhoz, hogy egy ilyen jellegü központ szolgáltatására legyen igény, ahhoz elöször azt kell belátnia annak, aki vállalkozni akar, hogy hol hiányosak az ő kompetenciái, és ez nagyon nehéz feladat."

A vállalkozók sok esetben nem látják be, hogy vannak olyan kompetenciák, amelyben hiányt szenvednek, és ha ebben valaki segítene, akkor növekedni tudnának. A szervezetet egyfajta virtuális inkubátornak képzeli el, ahol segítséget nyújtanak a vállalkozásalapításban, tárgyalót biztosítanak a megbeszélésekhez stb. Szükség van az önismeretre, amely során felszínre kerülnek a hiányosságok, és ezekben a hiányosságokba tudna a szervezet segíteni.

A tizenegyedik interjúalany szerint egyetlen egység nem lenne képes az SZTE-n ezeket a feladatokat megoldani. Ennek az egységnek

„eröteljesen kellene koordinálnia az egyes karokon dolgozó kollégákat... akkor dolgozik jól egy ilyen egység, ha ki tud építeni kapcsolatokat az egyetemen 100-150 kollégával, akik ebben aktívak."

\section{A fentiek érdekében milyen konkrét szolgáltatásokat nyújtson a GVK és milyen célcsoportoknak?}

A megkérdezettek esetében talán ennél a kérdésnél érződött leginkább, hogy a „szakértők”, vagy a „vállalkozók” csoportjába tartoznak. Nyilvánvaló módon minden válaszadó a saját szemüvegén keresztül látja és láttatja a helyzetet (célcsoportokat), ami azért jó, mert így, több oldalról megközelítve, viszonylag teljes képet kaphatunk a GVK lehetséges célcsoportjairól.

Értelemszerüen a „hallgatók célcsoportot” minden válaszadó megjelölte. Az első interjúalany szerint részükre ingyenes szolgáltatást kellene nyújtani (képzés, oktatás, látásmód változtatás, terelgetés formájában). A második interjúalany szerint a hallgatókon belül két célcsoportot lehet beazonosítani:

„egyrészt azok a hallgatók, akik gondolkodnak azon, hogy vállalkozást indítsanak, de nincs ehhez megfelelö üzleti ismeretük. Másrészt azok a hallgatók (volt hallgatók), 
akiknek saját vállalkozásuk van, de segítségre szorulnak üzleti tervezés, pályázat készítés, pénzügyi tervezés szempontjából."

A hatodik interjúalany kiemeli, hogy az ötlettel rendelkező hallgatók esetében nagyon nagy előny (pl.: az elérésük során), hogy már megvan a bizalom az SZTE-vel szemben, hiszen ide jártak, ismerik az egyetemet.

A hetedik és tizenegyedik interjúalany egyaránt a hallgatói célcsoportot jelöli meg első körben. Szerintük nem szabad egyszerre sok célcsoportot megcélozni, hanem egyet (hallgatók) kiválasztani és első lépésként rutint szerezni, ezt követően lehet diverzifikálni.

A hallgatókon túl az alábbi célcsoportok, illetve részükre nyújtandó szolgáltatások jelentek meg:

Életciklus alapján:

- Potenciális vállalkozók.

- Kezdő vállalatok: menedzsment, PMO, marketing, mentorálás, IPR, jogi képviselet, forráskeresés.

- Meglévő vállalatok: menedzsment, PMO, marketing, mentorálás, IPR, jogi képviselet, forráskeresés.

Típus szerint:

- Kutatók által alapított vállalkozások.

- Speciális vállalkozások: fast-growing, exit-orientált vállakozások.

- Low-tech szektor vállalkozásai.

- Klaszterek vállalkozásai.

Egyéb célcsoportok:

- Mentorálásba bevonható egyetemi és külső oktatók, szakértők, vállalkozók.

- Startup ökoszisztéma szervezetei, szereplői (inkubátorok, befektetők, vállalkozások stb.). 


\section{Ismer-e esetleg más felsőfokú intézményeknél olyan jó gyakorlatot, amelyet lehet adaptálni a GVK múködésére?}

Szinte minden interjúalany említett egy példát, amelyek nem feltétlenül adaptálhatók a GVKra, mégis tanulhatunk belölük.

Az első interjúalany konkrét jó gyakorlatot nem ismer, de említést tett Debrecen biotechnológiai spin-offjáról, ahol az egyetem ingyenes infrastruktúrát biztosított a lelkes fiatalok számára, akik erre építettek ki vállalkozásokat. Azonban megegyezi, hogy ezek a bevont infrastruktúrák alapvetően igen alacsony kihasználtsággal müködtek.

A második interjúalany a University of Pittsburgh gyakorlatát említette, ahol az egyetem a természettudományos kutatóknak olyan kézikönyveket ad, melyekben a találmányhasznosítás részletesen le van írva, így többek között a spin-off alapítás menetét is megismerhetik.

A harmadik interjúalany a Corvinus Egyetem által szervezett startup underground konferenciát tartja adaptálhatónak. A versenyre jó ötletekkel lehet jelentkezni, a legjobb projektek bemutatkoznak a döntőben, majd a befektetőkből álló zsűri választja ki a legjobbat.

A negyedik interjúalany több programot is megemlít. Németországban az EXIST program része a német kormány "Hightech Strategy for Germany" c. stratégiájának. A program célja a vállalkozói környezet fejlesztése az egyetemeken és a kutatóintézetekben, valamint tudás-, és technológiaintenzív startupok létrehozása. A Fedlab egy jól felszerelt labor, amely a hallgatók rendelkezésére áll és saját találmányaikat megpróbálhatják kivitelezni. A finn Demola program, amelyet hazánkban átvett a Mủegyetem, keretében egy valós problémára kell kreatív és innovatív megoldást találni. A problémákat olyan projekt partnerek, vállalkozások, intézmények stb. szolgáltatják, mint például Magyar Telekom, Canon, Sanoma stb. Továbbá megemlíti, hogy nagyon sok egyetemen a vállalkozásoktatás együtt van az innovációmenedzsmenttel, hiszen az egyetemek jórészt tudásvállalkozások (spin-off) alapításával foglalkoznak (Technology Transfer and Entrepreneurship), ezt az SZTE-n is hasonlóképpen lehetne megvalósítani.

Több interjúalany említette a Budapesti Müszaki Egyetem gyakorlatát, de nem fejtették ki a konkrét tartalmat.

A hetedik interjúalany a Heidelberg-i és Twente-i jó gyakorlatot emelte ki, mint adaptálható példákat. 


\section{A vállalkozásoktatáson belül Ön szerint milyen kompetenciákat kellene fejleszteni?}

A fejlesztendő kompetenciákat illetően teljes egyetértés van abban, hogy az alábbiak fejlesztése elengedhetetlen:

- problémamegoldás,

- kommunikáció,

- tárgyalástechnika,

- prezentáció,

- együttmüködés.

Az első interjúalany emellett kiemeli a „gondolkodásmódot”, ami alatt azt érti, hogy egy jó projektötletre kell létrehozni vállalkozást, megfelelő szakértők bevonásával és más vállalkozásokkal történő kooperációval.

A harmadik interjúalany az előzőeken túl számos fejlesztendő kompetenciát sorol fel: tervezés, szervezés, irányítás, vezetés, delegálás, az elemzés, a kommunikálás, a tapasztalatok értékelése, kockázatfelmérés és vállalás, egyéni és csapatmunkában történő munkavégzés, üzleti-vállalkozói szakmai kompetenciák.

Az ötödik interjúalany szerint komplex gondolkodásra való törekvésre nevelés a legfontosabb. Emellett a helyzetfelismerés (szituációk felismerése), és a döntéshozatal (tudatos döntések az érzelmi alapú döntések helyett) kompetenciák fejlesztésére kellene hangsúlyt fektetni.

A hatodik interjúalany egy igen érdekes dologra világított rá: úgy tapasztalta, hogy a mostani hallgatóknak (és vállalkozóknak is) rendkívül alacsony az EQ-ja (érzelmi intelligenciája), azaz „nem képesek beülni a tárgyalópartner székébe és az ő szemével ránézni az eseményekre”, pedig ez időt és energiát takarítana meg. Ez tapintatlanságban, türelmetlenségben, vagy olyan elvárások megfogalmazásában jelentkezhet, amire a másik nem képes. A vállalkozó felől közelítve, a vállalkozó nem gondolja végig, hogy kezdőként az adott hallgató nem ért hozzá, „zöldfülü”, még tanulnia kell. A másik oldalról a hallgató sem érzékeli, hogy verseny van, számos elvárással áll szemben, aminek meg kell felelni. Mindkét oldalon megjelenő kompetenciák erősítésére szükség van. Hasonlóan, a tizenegyedik interjúalany szerint a hallgatók nem igazán tudnak több szemszögből, több oldalról ráközelíteni egy adott problémára, ami egy vállalkozás életében nagyon fontos tényező. 
A hetedik interjúalany nagyon fontosnak tartja a kockázatviselést, illetve az erre történő felkészítést, hiszen a vállalkozók sokszor nem gondolják végig, hogy hány emberért felelősek, döntéseik milyen következményekkel járhatnak.

A kilencedik interjúalany szerint a „lehetőségek felismerésének” fejlesztése elengedhetetlen, hiszen a vállalkozói életben rendkívüli jelentősége van ennek a kompetenciának.

\section{A vállalkozásoktatáson belül a tényleges hatékony vállalkozóvá válás érdekében milyen ismereteket érdemes oktatni?}

A második interjúalany nagyon jól összefoglalja a megkérdezettek véleményét az általános ismeretekkel kapcsolatban, miszerint elsősorban a jogi, és számviteli ismereteket,

„ugyanis a legtöbben azért nem fognak vállalkozásba, mert talány nekik, hogy mit kell csinálniuk, hogyan és hova kell elszámolniuk dolgokat, egyáltalán hogyan müködik egy vállalkozás.”

Másodsorban üzleti ismereteket (pénzügyi tervezést, üzleti terv készítést), harmadsorban pedig általános üzleti ismereteket (menedzsment, marketing, HR, informatika) érdemes oktatni.

A negyedik interjúalany ennél jobban specifikál, szerinte az alábbiak oktatására sokkal jobban kellene fókuszálni:

- „üzletépítés, üzleti modellezés, nemzetközi kultúra (hogyan kell üzletelni egy japánnal)

- Az SZTE-nek olyan speciális területeken kell oktatni, amely az ötlettel rendelkezö fiataloknak segít a vállalkozásalapításban és képessé teszi öket arra, hogy befektetőkkel tárgyaljanak.

- A képzéseket szükségleti oldalról kell felépíteni, valós igény alapú oktatásra van szükség és nem kínálati oldalira."

A hatodik interjúalany szerint nagyon fontos, hogy többféle világnézettel találkozzanak a hallgatók a tanulmányaik során, ezáltal kiszakadjanak a közgazdász gondolkodásból és különböző szemszögekből vizsgáljanak egy adott problémát. Emellett a hallgatóknak be kell mutatni mind a multinacionális vállalatokban, mind a kis-és középvállalkozásokban rejlő (karrier) lehetőségeket. 
A tizenegyedik interjúalany az ismeretekkel kapcsolatban nagyon érdekes megjegyzést tesz, amit érdemes megfontolni: vállalkozás-specifikus ismereteket kell nyújtani, strukturálás nélkül:

„...hiszen egy vállalkozó - ha klasszikus formáját nézzük, akkor - innovatív módon kombinál, amihez, hogyha sémákat adunk, akkor pont a kombinálás lehetöségét fogjuk letörni. Ezért ezeket szabadon futó ismeretekként kezelném...keressen gondolati támpontokat, eszközöket, találjon módszereket, amiket - ha valóban vállalkozói attitüddel rendelkezik - akkor el fog kezdeni kombinálni.”

\section{Milyen oktatás-módszertani hátteret tartana a legeredményesebbnek a fentiek érdekében?}

Az interjúalanyok mindegyike egyértelmüen a kiscsoportos, gyakorlati oktatást emelte ki. E nélkül a hatékony, eredményes vállalkozásoktatás elképzelhetetlen.

$\mathrm{Az}$ első interjúalany szerint mindenképpen kiscsoportos, gyakorlati oktatásra lenne szükség, ahol tapasztalt, kiválóan kommunikáló vállalkozókkal történő beszélgetések során érdemi, gyakorlatban felhasználható tudást szerezhetnek a hallgatók. Emellett kiemeli, hogy sok múlik az előadó felkészültségén, illetve előadásmódján. A fentieknek megfelelően mindenképpen interaktív kurzusokat, valamint olyan miniprojekteket javasol, ahol a hallgatóknak 3-6 fős csoportokban kell vállalkozásfejlesztéssel kapcsolatos problémákat megoldaniuk, illetve ezt prezentálni. Az egyes csapatokban meg lennének osztva a feladatok, ki lenne jelölve egy „,projektvezető”, illetve lenne mellettük egy mentor, aki moderálná az egészet.

A második interjúalany kiemeli, hogy fontos, hogy

„olyan oktatók tartsák az órákat, akik ezzel foglalkoznak a mindennapi életben is, azaz van saját vállalkozásuk. Inkább gyengébb elméleti szakemberek (netán gyengébb elöadók), de a folyamatok beható ismerői legyenek."

Emellett a folyamatos, szigorú számonkérés elengedhetetlen, melynek során hétről-hétre kell beadandó dolgozatot készíteniük a hallgatóknak, ami vélhetően kevésbé lenne népszerü, azonban kiemelt kreditmennyiség esetén mégis sok hallgató választaná.

A tizedik interjúalany is hasonló módszertani kérdéseket feszeget:

„szigorúan gyakorlatorientáltat képzéseknek van ilyen területen érdemi hozadéka persze itt is a lehetöségek behatárolnak mindent. Minimum elvárás lenne, hogy minden 
új ismeretet legalább szimulációs játékon, esetpéldán kipróbálhassanak. A minimális arány fele elmélet, fele gyakorlat. Azaz tudásátadás, rögtön utána alkalmazási kísérlet. Ehhez megteremthető az IT háttér is. Számos vállalkozásos szoftver is va a piacon, illetve adaptálni is lehetne ilyet külföldi gyakorlatból. Akár jó értelemben vett „játékvállalkozásokat” is alapíthatnának a hallgatók.

A harmadik interjúalany az elözőeken túl kiemeli, hogy elengedhetetlen a gyakorló vállalkozók bevonása a kurzusokba, a hallgatói prezentációk elkészítése, és különböző játékos feladatok bevezetése. A hatodik interjúalany erre azt javasolja, hogy különböző vállalkozások (low-tech, high-tech, tanácsadó stb.) egy-egy képviselője hozzon be egy problémát az órára (vagy a hallgatóknak kell elmenni a cégekhez és a problémákat „,behozni”), amelyre kis csoportokban (4-6 fö) kell megoldást találniuk a hallgatóknak, ezt prezentálni, majd az oktató-vállalkozó együtt választaná ki a legjobb csapatokat, amelyeket esetlegesen pénzjutalommal díjazna.

A negyedik interjúalany szerint a leghatékonyabb oktatási módszer szintén a kiscsoportos problem-solving alapú oktatás, ahol a problémamegoldás és együttmüködés kompetenciák fejlesztése történik.

A hetedik interjúalany szerint az az alapvető probléma, hogy még mindig a lexikális tudás van túlsúlyban a projektmunkával szemben, ahol a hallgató kipróbálhatná magát: „Nincsenek valós élettapasztalatok.” Emellett azt javasolja, hogy kompetenciavizsgálattal elemezzék, hogy az egyes hallgatók mennyire alkalmasak a vállalkozói létre (vagy inkább alkalmazott típusúak).

A gyakorlati oktatással kapcsolatban a nyolcadik interjúalany egy rendkívül fontos tényezöre hívja fel a figyelmet:

„...lehetöségeket kell biztosítani a hallgatóknak, hogy kudarcokat is átéljenek. Ezáltal az önbizalmuk is nö és felkészülnek a kudarcok kezelésére.”

Továbbá hozzátette, hogy szükség van arra, hogy szembesítsék a hallgatókat az igazi képességeikkel annak érdekében, hogy kiderüljön róluk, hogy igazából miben jók.

„...a hallgató lehet, hogy azt hiszi magáról, hogy jó sales-es és ilyen vállalkozásban gondolkozik, de a tevékenysége során kiderül, hogy ő nem jó sales-es és jön a csöd, a 
kudarc. Azonban ha ez már korábban - egyetem alatt - kiderül, akkor ettöl meg lehet óvni öket.”

A kilencedik interjúalany szerint nagyon fontos az általános attitüdformálás: ne egy kurzust és krediteket lássanak a hallgatók, hanem egy hatalmas lehetőséget, ami az egész életüket megváltoztathatja.

A továbbiakban összefoglalom az egyes kérdésekre adott válaszokból kiszürhető legfontosabb eredményeket (24. táblázat). Az interjúk eredményei nagymértékben egybecsengnek a szakirodalom és szekunder kutatás eremdényeivel. Úgy tünik, hogy az elképzelések, lelkesedés már jelen van a szereplőkben, azonban még nem történtek meg az első lépések, mindenki (egyetem-vállalkozók) várakozó pozícióban van. A gyakorlati oktatás mind az egyetem lehetséges feladatainál, mind az eredményes vállalkozásoktatási módszertan esetén határozottan megjelenik, tehát az egyik legmeghatározóbb kitörési pontként tekinthetünk rá.

Azt, hogy egy elkülönült szervezeti egység jöjjön létre az SZTE-n belül szinte mindenki támogatta és konkrét (lehetséges) szolgáltatásokat társítottak hozzá, amelyeket külön választhatunk attitüd kialakításával és megerősítésével kapcsolatos szolgáltatásokra, illetve vállalkozásalapításhoz, és működtetéshez kapcsolódó szolgáltatásokra. A célcsoportok kialakítása során első körben minden interjúalany a hallgatók megcélzását tartja elsőrendü feladatnak.

Lukovszki (2011) a vállalkozói sikerhez szükséges tulajdonságokat azáltal, hogy megvizsgálta a vállalkozói tulajdonságok egymáshoz és a környezeti tényezőkhöz való kapcsolatát. A kutatási eredményei alapján arra a következtetésre jutott, hogy „egyetemi gazdasági képzések alkalmával is hangsúlyt lehetne helyezni a személyiségjegyek célirányos fejlesztésére" (Lukovszki 2011, 28. o.). Továbbá a legfontosabb tulajdonságok (kockázatkezelés, csoportmunka, lehetőség felismerése, kommunikáció, kockázatvállalás, valamint döntéshozatal) „középpontba állításával a leendő vállalkozók oktatásában lehetöséget teremtene arra, hogy a leendö vállalkozó hatékonyan felkészülhessen az elötte álló kihívásokra” (Lukovszki 2011, 28. o.). Mindez egybecseng a szakértői interjúk eredményeivel, ahol az előbbi eredményekhez hasonlóan a következő kompetenciák fejlesztését említették a leggyakrabban: problémamegoldás, kommunikáció, tárgyalástechnika, prezentáció, együttmüködés. 
24. táblázat: Szakértői interjúk eredményeinek összefoglalása

\begin{tabular}{|c|c|}
\hline Kérdések & Eredmények \\
\hline \multicolumn{2}{|r|}{ Vállalkozásfejlesztés } \\
\hline $\begin{array}{l}\text { Az SZTE hogyan tudná segíteni } \\
\text { hatékonyan és eredményesen a } \\
\text { hallgatók vállalkozóvá válását? }\end{array}$ & $\begin{array}{l}\text { - Gyakorlati oktatás } \\
\text { - Vállalkozói klubok, rendezvények } \\
\text { - Versenyek (üzleti terv versenyek, startup weekendek, } \\
\text { - startup konferenciák szervezése) } \\
\text { - „Vállalkozói”alumni erósítése }\end{array}$ \\
\hline $\begin{array}{l}\text { Ha erre létrejön egy elkülönült } \\
\text { szervezeti egység, véleménye } \\
\text { szerint milyen feladatai lennének? }\end{array}$ & $\begin{array}{l}\text { - Klub jellegü rendezvények szervezése. } \\
\text { - Workshopok szervezése } \\
\text { - Vállalkozói létforma és a vállalkozói tudat népszerüsítése } \\
\text { a hallgatók körében } \\
\text { - Későbbiekben akár inkubációs intézménnyé való } \\
\text { növekedés } \\
\text { - Nyílt napok szervezése } \\
\text { - Mentorálás } \\
\text { - Legjobb gyakorlatok összegyüjtése és megismertetése a } \\
\text { hallgatókkal, } \\
\text { - Tanácsadás, egyablakos módszerrel (pályázati } \\
\text { - tanácsadástól üzletviteli tanácsadásig) } \\
\text { - tájékókoztató füzetek gyártása } \\
\text { - Lehetőség biztosítása ahhoz, hogy megvizsgálják, hogy } \\
\text { az adott személy mennyire alkalmas arra, hogy } \\
\text { vállalkozó legyen } \\
\text { - Kezdő, innovatív vállalkozások számára forráskeresés, } \\
\text { forrásfelhasználás koordinálása } \\
\text { - Jogi, IPR, marketing stb. szolgáltatás biztosítása } \\
\text { - vállalkozásfejlesztési szervező-koordináló munka a-tól } \\
\text { z-ig” }\end{array}$ \\
\hline $\begin{array}{l}\text { A fentiek érdekében milyen } \\
\text { konkrét szolgáltatásokat nyújtson a } \\
\text { GVK és milyen célcsoportoknak? }\end{array}$ & $\begin{array}{l}\text { - Hallgatók } \\
\text { - Vállalkozók (potenciális, kezdő, müködő) }\end{array}$ \\
\hline \multicolumn{2}{|r|}{ Vállalkozásoktatás } \\
\hline $\begin{array}{l}\text { A vállalkozásoktatáson belül Ön } \\
\text { szerint milyen kompetenciákat } \\
\text { kellene fejleszteni? }\end{array}$ & $\begin{array}{l}\text { - } \text { problémamegoldás } \\
\text { - kommunikáció } \\
\text { - tárgyalástechnika } \\
\text { - prezentáció } \\
\text { - együttmüködés }\end{array}$ \\
\hline $\begin{array}{l}\text { A vállalkozásoktatáson belül a } \\
\text { tényleges hatékony vállalkozóvá } \\
\text { válás érdekében milyen ismereteket } \\
\text { érdemes oktatni? }\end{array}$ & $\begin{array}{l}\text { - a jogi, és számviteli ismeretek } \\
\text { - üzleti ismeretek (pénzügyi tervezés, üzleti terv készítés) } \\
\text { - általános üzleti ismeretek (menedzsment, marketing, HR, } \\
\text { informatika) } \\
\text { - } \text { speciális ismeretek }\end{array}$ \\
\hline $\begin{array}{lr}\text { Milyen oktatás-módszertani } \\
\text { hátteret tartana } \\
\text { legeredményesebbnek a fentiek } \\
\text { érdekében? }\end{array}$ & $\begin{array}{l}\text { - a kiscsoportos, gyakorlati oktatás } \\
\text { - a gyakorló vállalkozók bevonása a kurzusokba } \\
\text { - hallgatók szembesítése az igazi képességeikkel } \\
\text { - általános attitüdformálás }\end{array}$ \\
\hline
\end{tabular}

Forrás: saját szerkesztés 
A szükséges ismeretekkel kapcsolatban itt is megjelenik az alapvető jogi-, pénzügy-számviteli ismeretek fontossága, emellett olyan tudásra van szükség, amely a vállalkozásalapítás és müködtetés során segíti a vállalkozókat abban, hogy felismerjék a problémákat és tudják, hogy hol keressék a választ. Mindez tovább is vezet az eredményes oktatásmódszertani lehetőségekre, ahol az említett gyakorlati oktatás mellett a gyakorló vállalkozók bevonása, hallgatók szembesítése az igazi képességeikkel, illetve az általános attitüdformálás jelent meg legtöbb esetben.

\subsection{Vállalkozó hallgatók a Szegedi Tudományegyetemen, egy kutatás tapasztalatai - mélyinterjúk}

A szakértők - többségében - jövőre vonatkozó véleményének megismerése mellett további érdekes eredményeket kaphatunk, amennyiben megvizsgáljuk, vajon milyen specialitásokkal bírnak azon vállalkozók, akik már hallgatóként - a közelmúltban - belevágtak egy vállalkozás elindításába. Ennek a célnak az elérése érdekében a kutatásunk során húsz olyan vállalkozót kérdeztünk meg ${ }^{15}$, akik már hallgató korukban elindították vállalkozásukat, függetlenül attól, hogy jelenleg is abban a vállalkozásban tevékenykednek, avagy már egy újabb vállalkozásba kezdtek. Az interjúk tanulmányozása során tartalomelemzés segítségével ismétlődő motívumokat kerestünk a megkérdezettek válaszaiban annak érdekében, hogy megvizsgáljuk milyen közös pontok fedezhetőek fel, illetve milyen következtetéseket lehet levonni belölük.

Az első modulban az interjúalany azonosítására került sor, a második részben általános kérdéseket vizsgáltunk (pl.: vállalkozóvá válás története, tanulmányok és vállalkozás kapcsolata stb.), végül olyan speciális kérdésekkel zártuk az interjút mint például az alapításkor tapasztalt nehézségek, vagy vállalkozással szemben támasztott elvárások felidézése.

Ahogy a 25. táblázatból is látszik, sikerült különböző területeken tevékenykedő vállalkozókat elérni, így meg tudjuk vizsgálni, hogy vajon hasonló tapasztalatokkal rendelkeznek-e a vállalkozásalapítás és működtetés szempontjából.

\footnotetext{
1515 A kutatás a TÁMOP-4.2.1-08/1-2008-0002 számú „Tudáshasznosulást, tudástranszfert szolgáló eszköz- és feltételrendszer kialakítása, fejlesztése a Szegedi Tudományegyetemen és a Dél-alföldi Régióban” c. pályázat keretein belül valósult meg.
} 
25. táblázat: Az interjúalanyok beazonosítása

\begin{tabular}{|c|l|}
\hline Interjúalany & \multicolumn{1}{|c|}{ Szakterület } \\
\hline 1. & online marketing \\
\hline 2. & tanácsadás \\
\hline 3. & pályázatírás \\
\hline 4. & online marketing \\
\hline 5. & keresőmarketing \\
\hline 6. & MNS egyéb szórakoztatás, szabadidős tevékenység \\
\hline 7. & $\begin{array}{l}\text { humánkutatás és fejlesztés, gyógyszerkutatás és } \\
\text { fejlesztés }\end{array}$ \\
\hline 8. & festékkazetta javítás, festékszalagok cseréje \\
\hline 9. & bolti vegyes kiskereskedelem \\
\hline 10. & orvosi szoftverek gyártása \\
\hline 11. & $\begin{array}{l}\text { weboldalak készítése, tárhelyszolgáltatás, informatikai } \\
\text { szolgáltatások }\end{array}$ \\
\hline 12. & saját készítésú ékszerek, föként gyöngyékszerek \\
\hline 13. & $\begin{array}{l}\text { online internetes aukción keresztül régégek } \\
\text { értékesítése }\end{array}$ \\
\hline 14. & marketing és reklám \\
\hline 15. & textilkereskedelem \\
\hline 16. & szakfordítás \\
\hline 17. & esküvői weboldal \\
\hline 18. & horgászboltos \\
\hline 20. & vendéglátós \\
\hline & pályázatírás \\
\hline
\end{tabular}

Forrás: Saját szerkesztés

A továbbiakban a disszertációm szempontjából releváns területet vizsgálom, így a következő kérdésekre adott válaszokat összegzem:

1. Mennyiben befolyásolták az egyetemi tanulmányai a vállalkozásának alapítását, müködtetését?

2. Mennyiben befolyásolta a vállalkozás, a vállalkozó tevékenység a tanulmányait?

3. Milyen tényezőknek tudja be a vállalkozói/ a vállalkozás sikerességét?

4. Utólag visszatekintve, mennyiben rendelkezett a szükséges készségekkel, képességekkel a vállalkozás beindítása során?

5. Utólag visszatekintve, újra belefogna-e a vállalkozásba, továbbá ha újra belefogna hallgatóként fogna-e bele?

6. Szerinte mennyiben más egy hallgató által alapított vállalkozás, mint általában egy vállalkozás?

Az első két kérdés egyértelműen a vállalkozásoktatás, illetve a vállalkozás és tanulmányok egymás mellett meglétérének vizsgálatára vonatkozik. A következő két kérdés a szükséges kompetenciákat, illetve ezen belül a sikerhez szükséges kompetenciákat próbálja 
feltérképezni. Végül, az utolsó két kérdés a hallgatói vállalkozásokból leszűrhető tapasztalatokat veszi számba.

Ami a tanulmányok és vállalkozás kapcsolatát illeti a dél-alföldi vállalkozókhoz hasonlóan a megkérdezettek túlnyomó része ebben az esetben sem gondolta úgy, hogy az egyetemi tanulmányai segítettek volna a vállalkozásalapításban. Ahogy az első interjúalany fogalmaz „gyakorlatilag semmi értelme egyetemre járni ahhoz, hogy valaki az iparban elhelyezkedjen, hiszen nem a piaci igényekhez igazodik a jelenlegi oktatás." Hasonlóan a harmadik interjúalany úgy fogalmaz, hogy „nem az egyetemen fogja megtanulni az ember az üzleti élet alapvető téziseit." A második intejrúalany megjegyezte, hogy a vállalkozás beindításához szükséges tudás megszerzésére az idő előrehaladtával került sor a müködtetés során, továbbá „,nem a vállalkozás tevékenységének elvégzésével volt nehézség, hanem a jogi, adminisztratív teendök maradéktalan, biztos kézzel való elvégzésével." A 6. interjúalany úgy érezte, hogy pozitívan befolyásolták az egyetemi tanulmányai a vállalkozásának alapítását, müködtetését (azonban itt nem az üzleti, gazdasági területre gondolt. mivel a Bölcsészettudományi Karon erősítették a kreativitást, emellett széles látókört kapott, ami segített a vállalkozás beindításában, profiljának megalkotásában. Emellett a vállalkozó eldöntötte el, hogy jelentkezik a Gazdaságtudományi Kar (GTK) egyik üzleti képzésére, mert szeretné vállalkozói, üzleti ismereteit elmélyíteni, hogy még sikeresebb legyen a vállalkozása. Ugyanígy a 15. interjúalany az eredeti végzettsége mellett a későbbiekben beiratkozott a GTK mesterszakára, amelyet egyértelműen hasznosnak talált, tehát körvonalazódni látszik egyfajta törekvés arra vonatkozóan, hogy a sikeres vállalkozásalapítás érdekében a voltSZTE hallgatók visszatérnek az alma materükhöz. A 19. interjúalany esetében a tanulmányok egyértelmúen segítséget nyújtottak a cég müködtetésében kezdve a humánerőforrás-menedzsmenttől egészen a számviteli konzultációkig. A megkérdezettek tanulmányainak folytatását általában véve nem befolyásolta, zavarta a vállalkozóságuk.

A kompetenciák és sikeresség tényezőinek számbavételével kapcsolatban az első interjúalany sikeresség legfőbb tényezőjeként az „eszméletlen jó ötletek”-et emeli ki, azaz olyan üzleti konstrukció kialakítását, amelyet a konkurencia vagy nem mer alkalmazni, vagy nem is ismer. Ez együtt jár a kockázatvállalással, lehetőségek keresésével, továbbá kiemeli az ügyfélközpontúság fontosságát. Alapjaiban véve a legfontosabb kompetenciákként a következőket azonosították: lehetőség keresése, együttmüködés, kapcsolatok kialakítása, valamint rugalmasság. 
Ezek a kompetenciák azonban csak a vállalkozás müködtetése során alakultak ki, fejlődtek, a a megkérdezettek szinte egybehangzóan állították, hogy a vállalkozásalapítás előtt nem rendelkeztek a megfelelő képességekkel, készségekkel, legtöbb esetben a könyvelő(i)ket kérdezték meg a vállalkozók az aktuális problémákkal kapcsolatosan.

A sikertényezők esetében pedig az előzőeken túl a következők azonosíthatók be: szakterület kiváló ismerete, kitartó munka, minőségi kapcsolatrendszer, színvonalas szolgáltatás. Emellett érdekes eredmény, hogy a sikertényezőként többen említették a jó weboldalt és könnyü internetes elérési lehetőségeket, mint bármi más tényezőt.

Az utolsó két kérdéssel kapcsolatban két interjúalanyt leszámítva utólag visszatekintve mindenki belevágott volna újra a cégalapításba. Az első interjúalany szerint hallgatóként kevesebb ideje volt a vállalkozásra, nem volt annyira szervezett, egyszerübb, ha nincsen hallgatói státusz közben. A második interjúalany szerint „,hallgatóként elszántabbak az. emberek, sokkal jobban bíznak abban, amit csinálnak. Tulajdonképpen nem is a hallgató voltuk, hanem a koruk befolyásolhatja azt, hogy mennyire rendelkeznek a megfelelö vezetési képességekkel." Hasonlóan, a negyedik interjúalany szerint a hallgatók sokkal jobban bírják a stresszt, saját magukért küzdenek, agilisabbak és természetesen több időt tudnak a vállalkozásra szánni.

Összességében a különböző képzéseken megszerzett tudással kapcsolatosan alapjaiban véve elmondható, hogy függetlenül attól, hogy mely szakon végzett a megkérdezett, a tanulmányok nem igazán járultak hozzá sem a vállalkozóvá váláshoz, sem a vállalkozás működtetéséhez. Ez alól kivételt jelent néhány üzleti kurzus (pl. menedzsment, e-business), amelyeket kifejezetten hasznosnak ítéltek meg. Mindez arra enged következtetni, hogy a vállalkozás alapításához szükséges elméleti és gyakorlati oktatás iránt igény mutatkozik, hiszen jelenleg szerény az üzleti kurzusok kínálata. Ebből következően az egyetemek megfelelő képzések segítségével hozzájárulhatnak a sikeres vállalkozásalapításhoz.

Ami a megkérdezettek vállalkozásalapítás idején meglévő készségeit, képességeit illeti, elmondható, hogy a megkérdezettek magával a tevékenységgel kapcsolatos tudással rendelkeztek, azonban a vállalkozás alapításával, múködtetésével kapcsolatos ismereteknek nem voltak birtokában. Problémás esetekben a könyvelőhöz, ügyvédhez fordultak segítségért. Ilyen értelemben egyértelmüen jogosultsága van az egyetem által biztosított különböző vállalkozói és üzleti kurzusoknak (sőt, az esetek egy részében a szó 
szoros értelmében hiánypótlóak lennének). A sikerességgel kapcsolatban összességében megállapítható, hogy a hallgatók által alapított vállalkozások jelentős hányada „sikeresnek érzi magát”. A siker okaival kapcsolatos magyarázatoknál a várakozásoknak megfelelően alakultak az ismétlődő motívumok, egyrészt a konkrét ötlet minőségét és életképességét emelték ki kulcs sikerfaktorként, másrészt a kemény munkát, illetve a színvonalas szakmai tevékenységet.

Feltétlenül kiemelném, hogy a megkérdezettek túlnyomó része kellemes tapasztalatokkal rendelkezik a vállalkozói létformával kapcsolatban, és újra belefogna a vállalkozásba, akár hallgatóként is.

\subsection{A Szegedi Tudományegyetem vállalkozásoktatásával kapcsolatos megállapítások}

A primer kutatások bemutatása után - a kutatások eredményeihez kapcsolódóan megfogalmazom legfontosabb megállapításaimat.

6. Tézis: A hazai egyetemek szerepvállalása még nem megfelelöen erös a vállalkozóvá válás elösegítésében.

A 400 vállalkozást vizsgáló kutatás eredményei rávilágítottak arra, hogy a fogadói oldalon is eltérő elvárások jelennek meg az egyetem szerepvállalásával kapcsolatban. A dél-alföldi régióban a vállalkozók egyszerűen nem úgy tekintenek az egyetemre, mint vállalkozásalapításban és müködtetésben segítséget nyújtó intézmény. Egyelőre még az egyetem csupán a kapcsolatok kiépítésében játszik meghatározó szerepet a visszajelzések alapján.

7. Tézis: A sikeres vállalkozásoktatási tevékenység egyik legfontosabb kockázati tényezője pontosan a hallgatók által elképzelt jövőkép.

Az SZTE (volt) hallgatói körében végzett kutatásom során arról is meggyőződtem, hogy a jelenlegi hallgatók meghatározó hányada számára nem reális jövőkép a vállalkozóvá válás. A hallgatók túlnyomó része végzést követően alkalmazotti pozícióban képzeli el magát, elenyésző hányaduk gondolkozik vállalkozásalapításon. Hosszabb távon ez a kép kissé átalakul, azonban még mindig komoly lemaradások tapasztalhatók ezen a területen. Pontosan ezért bír kiemelt jelentőséggel a vállalkozói attitüd formálását szolgáló tevékenység, amely ilyen értelemben a vállalkozóvá válás „nulladik lépésének” tekinthető. Hiába építünk 
módszertanilag megalapozott, szakmailag tökéletességre törekvő vállalkozásoktatási rendszereket, ha hallgatói oldalról erre nincs érdemi igény.

8. Tézis: A Szegedi Tudományegyetemen belül - a szakirodalom és nemzetközi tapasztalatok alapján - szükség van egyetlen elkülönült szervezeti egységre, amely koordinálja a rendelkezésre álló szükös eröforrásokat, valamint az egyes karok vállalkozásfejlesztési-, vállalkozásoktatási tevékenységeit.

Az ötödik tézisből kiderült, hogy szükség van egyetemtől elkülönült szervezeti egységekre a vállalkozásfejlesztési, vállalkozásoktatási tevékenységekre, azonban az SZTE esetében elegendő egyetlen elkülönült szervezeti egység létrehozása az SZTE-n belül. Ezen egység meglehetősen sokszínű tevékenységet kell, hogy folytasson elkülöníthetők a vállalkozói attitűd kialakításával és megerősítésével kapcsolatos szolgáltatások, illetve a vállalkozásalapításhoz, és müködtetéshez kapcsolódó szolgáltatások. Az organikus fejlődés elvének megfelelően a célcsoportok kialakítása során első körben mindenképp a hallgatók megcélzását tartom elsőrendű feladatnak.

9. Tézis: Önmagában a sikeres vállalkozásoktatási tevékenység egyszerüen kevés. A gazdaságfejlesztés, és vállalkozásfejlesztés nem választható el egymástól, számos ponton kapcsolódnak egymáshoz.

Ahhoz, hogy az egyetemi ilyen irányú tevékenysége valóban hozzájáruljon az adott térség versenyképességének növeléséhez elengedhetetlen a párhuzamosan zajló tudatos gazdaságfejlesztési tevékenység. Annak érdekében, hogy az egyetemi oktatás (így a vállalkozásoktatás) keretein belül felkészített friss diplomások a régióban maradjanak, továbbá lokális vállalkozásokat alapítsanak, meg kell teremteni a megfelelő helyi üzleti környezetet, hálózatokat a vállalkozók számára, mindehhez azonban már egyértelmüen tudatos gazdaságfejlesztési beavatkozásokra is szükség van.

\subsection{SZTE vállalkozásfejlesztési-, vállalkozásoktatási modell kereteinek bemutatása}

Kutatásom lezárásaként a szakirodalmi áttekintés tapasztalatai, a megismert jó gyakorlatok, illetve a szakértői interjúk legfontosabb üzenetei alapján kísérletet teszek a SZTE vállalkozásfejlesztési-, vállalkozásoktatási modell keretrendszerével kapcsolatos javaslatok megfogalmazására. 
A konkrét javaslatok előtt, elöljáróban rávilágítnék a modell neuralgikus pontjaira, számos kockázati tényező jelenik meg egy ilyen jellegü tevékenység esetén (19. ábra).

19. ábra: Vállalkozásfejlesztés - vállalkozásoktatás kritikus pontjai

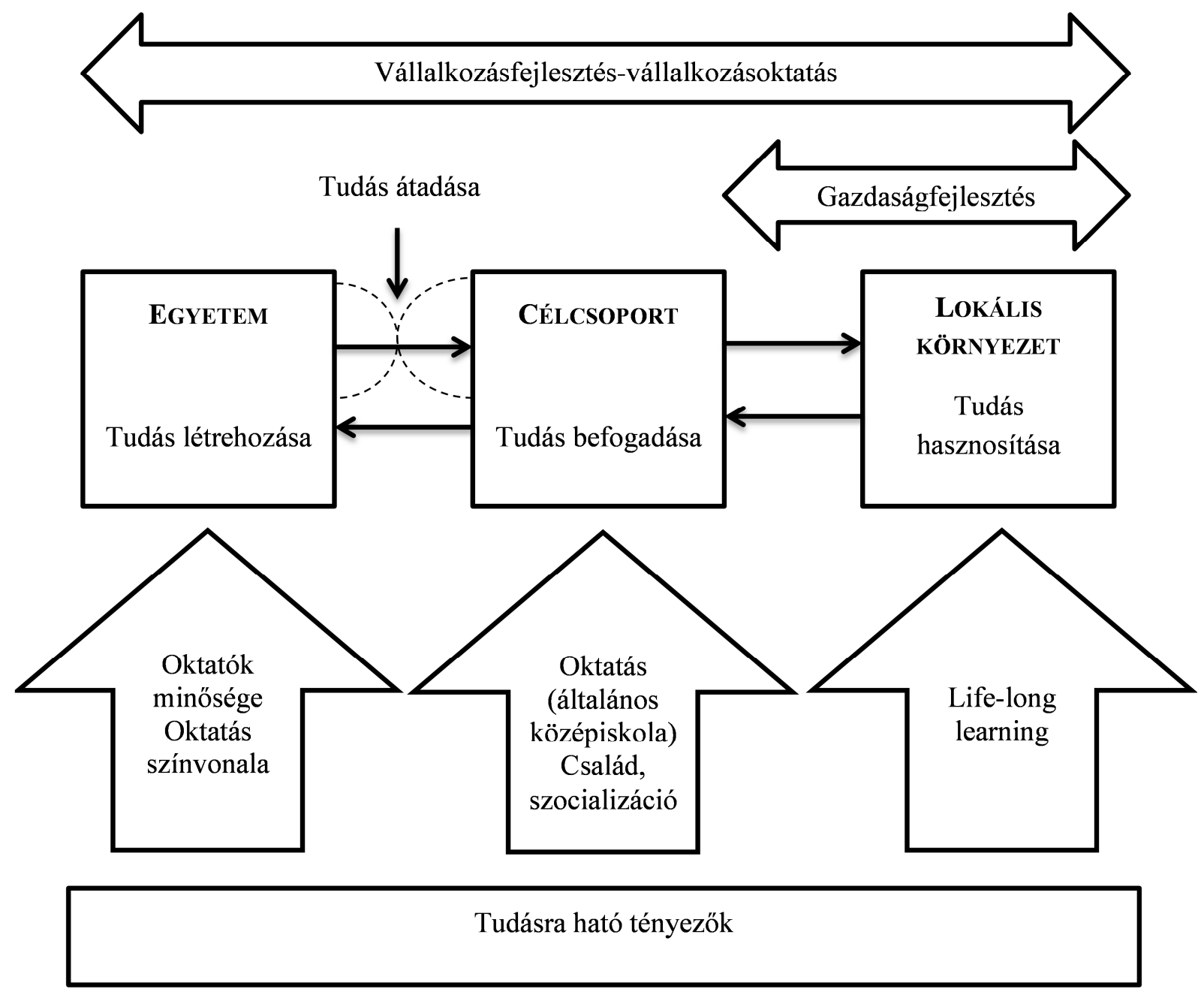

Forrás: saját szerkesztés

Amennyiben az egyetemet vizsgáljuk a „tudás” szempontjából, akkor az első problematikus terület a konkrét, átadandó tudás (képzéssel kapcsolatos és vállalkozói tudás) tartalma, mennyisége, minősége lehet. Szükséges feltétel az, hogy érdemi tudásbázis álljon rendelkezésre. A minőségi tudás létrehozásához elengedhetetlen a minőségi oktatói bázis. A tapasztalatok rámutattak, hogy érdemi vállalkozói kompetenciákkal rendelkező, hiteles személyiségekkel lehet eredményes vállalkozásoktatási tevékenységet folytatni. A 
vállalkozásoktatás szempontjából ez azt jelenti, hogy olyan oktatókra (is) szükség van, akik vállalkozói tapasztalattal és kompetenciákkal rendelkező gyakorló vállalkozók.

A következő neuralgikus pont a tudás átadásának mikéntje, azaz a lehető legjobb módszertani háttér. Meggyőződtem arról, hogy a tudás rendelkezésre állása csak szükséges, de nem elégséges feltétele a sikeres vállalkozásoktatásnak. Ehhez szorosan kapcsolódik a következő feltétel: az átadás során meglévő fogadó oldali aktivitás. Hiába állnak rendelkezésre a megfelelő módszertani eszközök, ha a fogadó oldal nem partner ezeknek az alkalmazásában (ábrán szaggatott vonal), emellett szükség van a folyamatos visszajelzésekre annak érdekében, hogy az egyetem felmérje a célcsoportok (hallgatók, kutatók, vállalkozók, általános-középiskolai tanárok) igényeit, illetve oktatás minőségét, megfelelőségét. Nem csupán arra kell helyezni a hangsúlyt, hogy mit nyújt, vagy nyújthat egy egyetem, hanem arra is, hogy az egyetemet látogató hallgatók milyen ,szolgáltatáscsomagokat” várnak el a felsőoktatástól. Éppen ezért meg kell vizsgálni a fogadó oldal általános motiváltságát, ha nem igénylik az ilyen jellegü kompetenciák bővítését, akkor gyakorlatilag irreleváns, hogy milyen ismeretek, milyen módszertannal történő átadására törekszünk. Ebben az esetben két kérdést kell megvizsgálni: szükség van-e a vállakozói tudásra, illetve képes-e befogadni a célcsoport ezen ismereteket. A vállalkozásoktatást illetően számos tényező befolyásolhatja mind a tudás átadás, mind a tudás befogadás folyamatát, így például a korábbi (általános- és középiskolai) oktatásban végzett vállalkozói attitüdformálás (vagy annak hiánya), közvetlen környezetben (család, barátok) fellelhető vállalkozói minták, szocializáció.

Végül, az utolsó kérdéskör a tudás hasznosítása, hiszen a tudás létrehozása, átadása, befogadása csak akkor eredményes, ha végül megfelelően hasznosul. A vállalkozásoktatás esetén a vállalkozói ismeretek megszerzése, kompetenciák kialakulása csak akkor fejt ki érdemi gazdaságfejlesztési hatást, ha a célcsoportok a régióban maradnak és itt hoznak létre vállalkozásokat (és nem külföldre viszik a tudást). Ellenkező esetben felléphet az „agyelszívás”, amikoris a képzett munkaerő elhagyja a régiót (Lengyel 2010). Ehhez azonban egyértelműen és határozottan szükség van a megfelelö üzleti környezetre, infrastruktúrára, hálózatokra (vállalati, egyetemi, $\mathrm{K}+\mathrm{F}$ ), helyi vállalkozások támogatására, mindehhez azonban már tudatos gazdaságfejlesztési beavatkozásokra van szükség.

A továbbiakban az SZTE vállalkozásfejlesztésével és vállalkozásoktatásával kapcsolatosan bemutatásra kerülnek a konkrét javaslataim. A javaslatok eső logikai egysége a sikeres szervezeti háttér kialakítására és múködtetésére vonatkozó javaslatok, amelyeket „elvek” 
szintjén fogalmazok meg. A második logikai egység az összességében a vállalkozói attitüd fokozásával kapcsolatos javaslatok halmaza. Az általános megállapítások mellett ezen a területen már konkrét lehetőségek, akciók is bemutatásra kerülnek. A harmadik logikai egység az összességében a szervezet által nyújtott konkrét vállalkozásfejlesztési-, különösen vállalkozásoktatási szolgáltatásokkal kapcsolatos javaslatok halmaza (20. ábra).

20. ábra: Javaslatok felépítése

\begin{tabular}{|l|l} 
Szervezeti & $\begin{array}{l}\text { Sikeres szervezeti háttér kialakítására és müködtetésére vonatkozó } \\
\text { javaslatok }\end{array}$ \\
\hline
\end{tabular}

- Elkülönült szervezeti egység elve

- Organikus fejlődés elve

- Egyetem „entrepreneurship tudásvagyonának” kezelésének elve

- Belső partnerség elve

- Külső partnerség elve

\section{Vállalkozói attitüd}

- Klub jellegü, informális rendezvények

- Workshopok

- Különböző versenyek szervezése

- Meglévő kezdeményezések továbbgondolása

\section{Konkrét VF, VO szolgáltatások}

- Kiscsoportos gyakorlati oktatás

- Vállalkozók bevonása az oktatásba

- Formális klubok, rendezvények

Forrás: Saját szerkesztés

\subsubsection{Szervezeti javaslatok}

A javaslatok első szintje a szervezeti javaslatok, amelyek az alábbi elvek mentén rendszerezi a Központ szervezetével kapcsolatos elképzeléseimet:

- Elkülönült szervezeti egység elve.

- Organikus fejlődés elve.

- Egyetem „entrepreneurship tudásvagyonának” kezelésének elve. 
- Belső partnerség elve.

- Külsőpartnerség elve.

\section{Elkülönült szervezeti egység elve}

A nemzetközi jó gyakorlatok és az áttekintett egyetemi példák világosan rámutattak, hogy az egyetemen egy elkülönült, relatíve önállóan müködő vállalkozásfejlesztési központot kell kialakítani, amely koordinációs feladatokat lát el, valamint szolgáltatásokat nyújt mind az egyetem egésze számára, mind pedig a külső stakeholderek irányába. Értelemszerüen egy ilyen szervezeti egység müködtetésére és fenntartására csak abban az esetben van szükség, ha valóban sikerül megtölteni érdemi tartalommal. Ezzel összhangban rendkívül érdekes kérdés a szervezet finanszírozása. Az ilyen jellegü beavatkozásoknál egy viszonylag járható útnak tünik egy három szinten megvalósuló finanszírozási lépcső, amely megteremti a minimálisan szükséges hátteret.

- Induló finanszírozás. Ez főszabályként az SZTE feladata. Mérlegelésre érdemes, hogy a Központ által Egyetemre befelé nyújtható potenciális szolgáltatások, illetve a későbbiekben esetleg bekövetkező jövedelemtermelő képesség lehetősége „,mennyit ér meg”. Értelemszerüen ez a tényleges indulási fázis valamilyen időtávon történő finanszírozása.

- Pályázati forrásokból történő bevételszerzés. Amennyiben a minimálisan szükséges humán és tárgyi infrastruktúra rendelkezésre áll kézenfekvő forrásszerzési lehetőség, áttekintve a következő programozási periódusra vonatkozó elképzeléseket az „entrepreneurship” az egyik kiemelt fókusza a fejlesztéseknek. Gyakorlatilag kizárt eset, hogy - amennyiben erre valóban van közös egyetemi akarat - ne lennének beleilleszthetőek a Központ bizonyos aktivitásai különböző H2020-as, illetve hazai operatív programok pályázataiba, illetve ne tudna akár a Központ önálló pályázatokat benyújtani. Jelenleg is pályázati forrásból üzemel ezen kezdeményezés.

- Saját szolgáltatási bevételek. A sikeres nemzetközi példák világosan rámutattak, hogy egy színvonalas szolgáltatási portfólióval rendelkező vállalkozásfejlesztési központ érdemi jövedelemtermelő képességgel bírhat. Ez a lehető legtágabban értelmezendő, ebbe a körbe besorolhatók a különféle képzésekből, tanácsadásokból realizálható direkt bevételektől egészen a mentorált vállalkozások jövőbeni bevételeinek központra eső részéig minden - ami jelen szervezet esetén saját „üzleti” tevékenységének bevételének tekinthető. 
Ezzel kapcsolatban feltétlenül megjegyezném, hogy a finanszírozás kérdése fontos, de egyértelmủen nem elsődleges kérdés. Mind a személyes véleményem, mind a szakértői interjúk alapján kijelenthető, hogy az akarat (mind egyetemi vezetői szinten, mind a Központ munkatársainak szintjén), elkötelezettség, motiváció számottevően fontosabb, mint a finanszírozás problematikája. Ráadásul - amennyiben érdemi eredményeket sikerülne felmutatni - meggyőződésem, hogy a szükséges finanszírozási háttér is megteremtődne mind egyetemi, mind vállalati oldalról.

Másik oldalról hosszabb távon egy Központtal szemben teljesen reális elvárás, hogy biztosítsa fenntartását, azaz a müködési önfenntartás elérése alapkövetelmény ${ }^{16}$. Meggyőződésem, hogy a pályázati és üzleti bevételek - megfelelően színvonalas müködtetés mellett - már rövidtávon belül is biztosítani tudják a Központ fennmaradását, illetve szükséges fejlődését.

\section{Organikus fejlödés elve}

Általánosságban azért az interjúalanyok jelentős hányada egyetértett abban, hogy a Központnak egy „organikus fejlődésen” kell keresztülmennie, mind a célcsoportok, mind a nyújtott szolgáltatások tekintetében. Kiindulásként érdemes átgondolni azt az alapvető kérdéskört, hogy pontosan milyen célcsoportnak milyen szolgáltatásokat kell nyújtani (Ezzel a kérdéskörrel a konkrét aktivitásoknál részletesen foglalkozom). Föszabályként első az egyetemen belüli célcsoportoknak (hallgatók, kutatók) lehetne elöször a szemléletformáló rendezvényeket, partnerség építéseket nyújtani, illetve az egyszerübb szolgáltatásokat biztosítani (különös tekintettel a vállalkozói képzésekre). Ahogy az interjúk is rámutattak minden szervezetnek folyamatosan kell felépülnie, így a Központnak is első lépésben a hallgatókat, kutatókat kell megcéloznia egyrészt azért, mert könnyen elérhetőek, másrészt azért is, mert már létezik egyfajta bizalom a szereplők között. Majd a szervezet tanulásával és erősödésével párhuzamosan kellene bővíteni mind a célcsoportot, mind a nyújtott szolgáltatások körét. Bármely célcsoportot is nézzük, nagyon fontos az egyes csoportok szükségleteinek felmérése, illetve a kereslet megteremtése.

\footnotetext{
${ }^{16}$ Már csak azért is, mert a Központ - többek között - a vállalkozóvá váláshoz, illetve sikeres müködéshez nyújtana segítséget, így igen visszás képet mutatna, ha önfenntartásra képtelen egy ilyen jellegű szolgáltatásokat nyújtó intézmény.
} 


\section{Egyetem „,entrepreneurship tudásvagyonának” kezelésének elve}

Különösen fontos (kiemelt) feladat lehetne egy ilyen Központ számára az „entrepreneurship tudásvagyon" kezelése. Jelenleg nincs egy áttekintő összegzés arról, hogy milyen vállalkozástámogatási projektek zajlottak, zajlanak jelenleg is az SZTE-n, nincsenek ezekkel kapcsolatban összegezve a tapasztalatok, jó gyakorlatok. Számos sikeres és kevésbé sikeres kezdeményezés volt az elmúlt néhány évben, érdemi megalapozó tanulmányok születtek, tényleges primer kutatások zajlottak. A Központ egyik alapfeladata ennek a közös tudásnak, tapasztalathalmaznak a naprakészen tartása, szintetizálása lenne, amely hosszabb távon kiegészülhetne ezen tudás megosztásával is, első körben egyetem belül, második körben akár egyetemen kívül is. Ennek a feladatnak a megvalósítása biztos alapot jelenthetne a lehetséges fejlődési lehetőségek feltérképezéséhez, illetve a további koordinált vállalkozástudományi kutatások folytatásához. Ezen felül egy érdemben karbantartott tudásvagyon ezen a területen számos területen kézzelfogható előnyöket jelenthet kezdve a vállalkozói attitűdformáló rendezvényektől egészen a jövőben benyújtandó pályázatok megalapozásáig. Összességében érdemes létrehozni egy „entrepreneurship tudástár”-at, amely összegyűjti az eddigi jó gyakorlatokat, tapasztalatokat és mindezt elérhetővé kell tenni az egyetemi polgárok részére.

\section{Belső partnerség elve}

A SZTE-n belüli együttmüködés (Innovációs Igazgatóság + Központ), együtt gondolkodás jelentős mértékben növelné az egyes kezdeményezések, programok sikerességét. A tudásintenzív gazdaságban az innováció és a vállalkozás szorosan összekapcsolódó fogalmak. Éppen ezért a megfelelő intézmények együttműködése elengedhetetlen a sikeres és hatékony működés eléréséhez.

Bármilyen tevékenység esetén kulcstényező az egyes karokkal történő szoros együttmüködés. Több interjúalany is rámutatott, hogy a Központ egyik legfontosabb feladata a koordináció, illetve a Karokon tevékenykedő lelkes emberek munkájának támogatása lehet. Ehhez viszont alapfeltétel a szoros partneri kapcsolat.

A formalizált, SZTE-n belüli intézmények közötti kapcsolatok mellett nagyon fontos az az alumni kapcsolatok ápolása. Az SZTE-n végzett sikeres vállalkozók oktatásba, informális rendezvényekbe történő bevonása, vagy akár különböző versenyek - szakértői, pénzügyi támogatására történő felkérése szintén egy fejlesztendő terület. 


\section{Külső partnerség elve}

Az amerikai és európai példák tapasztalatainak megfelelően az alábbiak létrehozását érdemes végiggondolni:

- Lokális és globális stratégiai partnerek hálózata

- „Business lab” létrehozása

A lokális és globális stratégiai partnereken belül az alábbi hálózatok kiépítésére lenne szükség a hatékony vállalkozásoktatás és vállalkozásfejlesztés érdekében:

- Kis-és középvállalkozások összegyüjtése, amelyek biztosítják a mentorokat a hallgatók számára, valamint az egyetemi kurzusokba integrálásukkal nagymértékben hozzájárulnak a vállalkozásoktatás hatékonyságának növeléséhez. Kis-és középvállalkozók bevonása a képzésbe és saját példájukon keresztül a hallgatók megismerkedhetnek ezzel a létformával.

- Amerikai és európai egyetemek hálózata, amelyek biztosítják a hallgatói mobilitást, hallgatócserét, amely a nemzetközi példák szerint egyik meghatározó részét képezik a vállalkozásoktatásnak.

- Nemzetközi kapcsolatok erősítése a régióban: nyitni Szerbia, Románia felé. Ki kell használni, hogy egy lépéssel előrébb járunk, ki kell használni az ebben rejlő lehetőségeket.

A „Business lab” egy olyan teret és alkalmat teremt a hallgatóknak, ahol megoszthatják ötleteiket, vállalkozásalapítással kapcsolatban támogatást kaphatnak, illetve hasonló elképzeléssel, motivációval rendelkezők egyfajta gyüjtőhelyet hoz létre.

\subsubsection{Vállalkozói attitűd fokozásával kapcsolatos javaslatok}

Jelenleg a vállalkozóvá válás még mindig nem reális jövőkép, bár a startupok előtérbe kerülésével már a hallgatókorban is többen elgondolkoznak a vállalkozásalapításon. Azonban általában véve a hallgatókban nincs még meg az a vállalkozói attitüd, ami vállalkozásalapításra késztetné őket. Mindez visszavezethető arra, hogy a középiskolában nem találkoznak vállalkozói attitüdformáló tanórákkal, előadásokkal, így azoknál, akik a családjukban nem találkoznak vállalkozókkal nem alakul ki, nem tud kialakulni a vállalkozói attitüd. Mindez tovagyürüzik az egyetemen, ahol a hallgatók másod-harmadéves korukra jutnak el arra a szintre, ahol elkezd formálódni az egyetem oktatói, közege által a vállalkozói 
attitűd, ami már majdhogynem késő. Éppen ezért szükség van olyan lehetőségekre, amelyek akár informális kereteken belül - elősegítik az attitüdformálást.

Az alábbiakban néhány, konkrét akciót fogalmazok meg, amelyek megvalósítása viszonylag kis ráfordítással a közeljövőben megvalósíthatók:

- Klub jellegü, informális rendezvények szervezése, ahol vállalkozók-hallgatók kötetlenül beszélgethetnek a vállalkozói létformáról, tapasztalataikról.

- Workshopok szervezése a vállalkozási sikeresség növekedése érdekében.

- Különböző versenyek szervezése (üzleti terv, startup stb.).

- Az SZTE-n jelenleg is múködő „Használhatóbb tudást - hasznosabb munkaerőt!” hallgatói gyakornoki program több klaszterre történő kiterjesztése, valamint több gyakornoki hely megteremtése nagymértékben hozzájárulna a valós gyakorlati tapasztalatok és tudás megszerzéséhez.

\subsubsection{Konkrét vállalkozásfejlesztési-, különösen vállalkozásoktatási szolgáltatásokkal kapcsolatos javaslatok}

A konkrét szolgáltatások megnevezéséhez elsősorban a megfelelő célcsoportok kiválasztására van szükség. Első körben a megcélzott célcsoport a hallgatók lennének, hiszen az SZTE őket tudja legkönnyebben és leghatékonyabban elérni. Emellett a Központnak is egyfajta rutint kell szerezni ahhoz, hogy sikeresen múködjön és „beletanuljon” a folyamatokba. A későbbiekben ez a kör kibővülhet a potenciális vállalkozókra, meglévő vállalkozókra stb. Ennek megfelelően a szolgáltatások is fejlődnének és bővülnének az egyes célcsoportok igényeinek megismerésével és a szükséges gyakorlat megszerzésével.

Amennyiben a hallgatókat nézzük, akkor az szakirodalom, az amerikai, nyugat-európai, valamint szakértői interjúk alapján a következő pontok mentén szükséges vizsgálódnunk (14. táblázat):

1. Kiscsoportos gyakorlati oktatás

2. Vállalkozók bevonása az oktatásba

3. Formális rendezvények, fórumok

\section{Kiscsoportos gyakorlati oktatás}

Mind a nemzetközi gyakorlat, mind a szakértői interjúk egyértelmüen alátámasztják, hogy az egyik legfontosabb, ha nem a legfontosabb vállalkozásoktatási szolgáltatás a kiscsoportos, 
gyakorlati oktatás. A gyakorlati oktatáson belül a következő kompetenciák fejlesztésére kiemelten kellene koncentrálni: problémamegoldás, kommunikáció, tárgyalástechnika, prezentáció, együttműködés.

\section{Vállalkozók bevonása az oktatásba}

A vállalkozók oktatásba történő bevonása többféleképpen képzelhető el. Egyrészt, mint meghívott előadók számos élettapasztalatot, esettanulmányt hozhatnak be a vállalkozói létformát illetően. Mindez leginkább BA szinten, vállalkozói attitüd formálásként lehet érdekes (ld. előző alfejezet). Másrészt - ami a vállalkozásoktatás eredményességét tekintve számottevően hatékonyabb - az egyes vállalkozók konkrét, valós problémákat hozhatnak be a kurzusokra, amelyeket kis csoportokban kell feldolgozniuk a hallgatóknak, és amelyekre megoldást kell keresniük. A „díjazás” ebben az esetben lehet érdemjegy, pénzjutalom stb., ami függhet a vállalkozótól, a problémától, de összességében az érdemi hatása nem ebben mutatkozik meg. A vállalkozók szempontjából szintén előnyös lehet az oktatásban történő részvétel, hiszen lehetőséget teremt a potenciális jövőbeni munkavállalóikkal történő együttmüködésre, megismerkedésre.

\section{Formális klubok, rendezvények}

Az előző fejezetben bemutatott informális klubok mellett formális, hallgató-vállalkozó találkozókra is szükség van. Ebben az esetben is nagyon fontos tényező az interaktivitás. A vállalkozó ne csak elmondja a „saját történetét”, hanem gondolkodásra, együttmüködésre ösztönözze a hallgatókat egy-egy probléma, nehézség, tipikus buktatók stb. átbeszélésével.

A hallgatói célcsoport elemzése során figyelembe kell venni azt is, hogy az elmúlt években a hallgatók „minőségében” és jövőképükben is megfigyelhető egyfajta változás:

- A hallgatók egy részéről elmondható, hogy nem olyan felkészült, mint 2-3 évtizeddel ezelőtt. Éppen ezért biztosítani kell az értelmesebb rétegnek egy olyan lehetőséget, ahol kihasználhatja, kipróbálhatja a képességeit, illetve fejlesztheti azokat. Ehhez megfelelő hátteret és infrastruktúrát biztosíthatna a Központ.

- Az intelligens hallgatók egy része külföldre megy dolgozni. Ezáltal egyrészt pont az értelmes, szakképzett munkaerőt veszítjük, másrészt az oktatás, a megszerzett tudás sem itthon hasznosul. A korábban említett hallgatói mobilitás megteremtése mellett ösztönözni kell a hallgatókat az itthon maradásra, de ehhez meg kell teremteni azokat 
a lehetőségeket, amelyek ezt elősegítik. Így például segítségnyújtás az ötleteik piacosításában, finanszírozás megtalálásában, stb.

- Hazánk elhagyása mellett megfigyelhető egy országon belüli mobilitás is, hiszen a hallgatók egy másik része nagyvállalatokhoz szegődik a fővárosba. A vállalkozásoktatás egyik nagyon fontos eleme megmutatni, hogy lokális szinten, kkvékhoz elszegődve, avagy saját ötletre épülő vállalkozásalapítással is lehet karriert építeni. A hallgatóknak meg kell mutatni azokat a lehetőségeket, amelyeket a diplomájuk biztosít részükre. Mindez a kurzusokra, (vagy informálisabban) fórumokra meghívott, különböző vállalkozások (helyi kkv-k, nagyvállalkozások részlegének stb.) képviselőinek beszámolóival sikeresen megvalósítható. 


\section{7. Összegzés}

Értekezésem elkészítése során célként az SZTE vállalkozásfejlesztési-vállalkozásoktatási modell kereteinek kidolgozását jelöltem meg az amerikai és nyugat-európai jó gyakorlatokból adaptálható módszerek felhasználásával. Reményeim szerint sikerült feltérképeznem az adaptálható módszereket, illetve igen komoly terjedelemben vizsgáltam a vezető egyetemek gyakorlatát.

Úgy vélem az elméleti megalapozás során sikerült szintetizálnom a vállalkozásoktatással kapcsolatos legfontosabb ismereteket, számos oldalról megközelítettem, hogy mennyiben segíthető elő a vállalkozóvá válás. Áttekintettem, hogy egyes elméletek szerint tanítható-e az „entrepreneurship”, illetve legalább valamilyen körülhatárolható része. Ezt követően a vállalkozásoktatás fogalmát, céljait tekintettem át annak érdekében, hogy kijelöljek egyfajta határt, amelyen belül tovább vizsgálódok. Bízom benne, hogy ezen áttekintésem hozzájárul a hazai vállalkozástudomány, de különösen a vállalkozásoktatás elméleti megalapozottságához.

Véleményem szerint az SZTE vállalkozásfejlesztési-vállalkozásoktatási modell kereteinek kidolgozásához szükséges mind az elméleti modellek áttekintése, mind a gyakorlati példák elemzése. Éppen ezért kísérletet tettem az elméleti modellekből, valamint az amerikai és nyugat-európai gyakorlatokból adaptálható módszerek összegyüjtésére, szintetizálására, illetve a leggyakrabban megjelenő jó gyakorlatok adaptációs lehetőségeinek feltérképezésére. Ennek érdekében a különböző rangsorok alapján kiválasztottam a legjobb vállalkozói képzéssel bíró európai és amerikai egyetemeket, majd egy előre meghatározott szempontrendszer alapján részletesen elemeztem 10 európai és 9 amerikai vezető egyetem vállalkozásoktatási gyakorlatát.

Kutatásom következő részében tizenegy strukturált szakértői interjút készítettem az egyetem vállalkozástámogatási tevékenységével kapcsolatban. A szakértői interjúkon alapuló kvalitatív kutatásom kettős céllal készült. Egyrészt a nemzetközi példák megismerése, illetve az általam átvehetőnek, adaptálhatónak vélt gyakorlatok kiszürése után, helyi szinten is megvizsgáljam, hogy a lokális szakértők, tudásintenzív vállalkozók milyen lehetőségeket, illetve milyen esetleges további feladatokat képzelnek el az SZTE vállalkozásfejlesztési-, vállalkozásoktatási modell keretrendszerével kapcsolatosan. Másrészt célul tủztem ki, hogy a nemzetközi (amerikai, európai) és helyi szinten összegyüjtött eredmények, közös pontok alapján körvonalazzam, valamint (lehetőségeimhez mérten) konkrét tevékenységekkel töltsem 
fel az SZTE vállalkozásfejlesztési-, vállalkozásoktatási modell keretét. Az elkészített szakértői interjúkat az ismétlődő témák rendszerezése alapján elemeztem, igyekezve kiemelni a gyakran megjelenő véleményeket, nézőpontokat az egyes felvetett kérdésekkel kapcsolatban.

Értekezésem zárásaként kísérletet tettem konkrét javaslatok megfogalmazására az SZTE vállalkozástámogatási aktivitásaival kapcsolatban, különös tekintettel a vállalkozásoktatásban rejlő lehetőségekre. Az áttekintett és szintetizált amerikai és európai jó gyakorlatok, illetve a szakértői interjúk következtetései alapján kijelöltem a legfontosabb lehetséges beavatkozási területeket, illetve néhány programot is felvázoltam. A lehetséges aktivitásokat tipizáltam.

A javaslatok eső logikai egysége a sikeres szervezeti háttér kialakítására és müködtetésére vonatkozó javaslatok, amelyeket „elvek” szintjén fogalmaztam meg, ezek általában határozták meg az SZTE vállalkozástámogatásával kapcsolatos legfontosabb elvárásokat. A második logikai egység az összességében a vállalkozói attitüd fokozásával kapcsolatos javaslatok halmaza. Az általános megállapítások mellett ezen a területen már konkrét lehetőségek, akciók is bemutatásra kerülnek. A harmadik logikai egység az összességében a vállalkozásfejlesztési szervezet által nyújtható konkrét vállalkozásfejlesztési-, különösen vállalkozásoktatási szolgáltatásokkal kapcsolatos javaslatok halmaza.

Bízom benne, hogy kutatómunkámmal egyrészt sikerült hozzájárulnom a hazai vállalkozásoktatás elméleti megalapozásához, mert kutatómunkám során észleltem, hogy ez a terület a fontosságához képest meglehetősen alacsonyan kutatott. Másrészt remélem, hogy az általam megfogalmazott javaslatok valamilyen mértékben hozzájárulnak az egyetemi vállalkozásoktatási gyakorlat javulásához és ezáltal a vállalkozóvá válás elősegítéséhez.

Végezetül néhány szubjektív megjegyzés, amely az elmúlt néhány év vizsgálatai során fogalmazódott meg bennem.

Kutatásaim közben egy rendkívül érdekes kettősséggel szembesültem. Annak ellenére, hogy gyakorlatilag minden uniós és hazai dokumentum kulcsfontosságú területként kezeli a vállalkozókészség fokozását, a vállalkozóvá válás elősegítését, illetve a vállalkozásoktatást szinte évek óta nem történik semmi. Az elmélet és a gyakorlat rendkívül messze van egymástól ezen a területen is. 
Vizsgálódásaim során egy mellékes területként kísérletet tettem a hazai felsőoktatási gyakorlat áttekintésére is. Természetesen a tájékozatlanság is szerepet játszhat a véleményem megfogalmazásában, de mind a saját vizsgálataim, mind az elolvasott publikációk, mind a szakértők véleménye alapján egyrészt kijelenthető, hogy elképesztő lemaradásaink vannak mind az európai mind az amerikai gyakorlattól. Másrészt a hazai aktivitások is rendkívül szigetszerüek és szerények: Szegeden kívül szorosan értelmezett érdemi és komplexebb vállalkozástámogatási tevékenység ismereteim szerint Budapesti Corvinus Egyetemen, a Budapesti Müszaki és Gazdaságtudományi Egyetem, illetve a Pécsi Tudományegyetemen folyik.

Zárásként - és az előző negatívumok árnyalásaként - két pozitív gondolat.

Az egyik egy rendkívül kedvező visszajelzés, amely egyben jó indikátor is. A megkérdezett interjúalanyok meghatározó hányada egyértelmủen pozitívumként értékelte, hogy egyáltalán gondolati szinten felmerült egy számottevően markánsabb egyetemi szerepvállalás ezen a területen. Ami lehet, hogy még fontosabb: a pozitív visszajelzések mellett többen jelezték, hogy szívesen bekapcsolódnának a Vállalkozásfejlesztési Központ tényleges munkájába is...

Másrészt az elmúlt néhány évben meggyőződésemmé vált (és ebben is többen megerősítettek), hogy a hazai egyetemek általános vállalkozástámogatási elmaradottsága egy igen jó lehetőség is számunkra. Egy európai színvonalhoz közelítő, tényleges eredményeket produkáló vállalkozástámogatási és vállalkozásoktatási portfólió kialakításával az SZTE egy olyan magkompetenciát alakíthatna ki, amely megfelelő marketingtevékenységgel párosulva komoly versenyelőnyt jelenthetne az egyre élesedő felsőoktatási versenyben... 


\section{Irodalomjegyzék}

Alberti, A - Sciascia, B. - Poli (2004): Entrepreneurship Education: Notes on an Ongoing Debate. 14th Annual IntEnt Conference. University of Napoli Federico II, Italy.

Andrijevskaja, J. - Mets, T. (2007): Entrepreneurial Challenge for University and its Region in a Transition Country: Case of Tartu, Estonia. In: Braun, G. - Diensberg, C. (eds): Cultivating Entrepreneurial Regions - Cases and Studies from the Network Project 'Baltic Entrepreneurship Partners',(BEPART). Universität Rostock, 273-297.o

Audretsch, D. B. - Thurik, R. (2001): Linking Entrepreneurship to Growth. OECD Science, Technology and Industry Working Papers, 2, OECD Publishing, Paris.

Barakonyi K. (2004): Egyetemi kormányzás: Merre tart Európa? Közgazdasági Szemle, (51) 6, 584-599. o.

Barakonyi K. (2009): A business schoolok szerepváltozásai - Kihívások és változások a menedzserképzésben és az MBA-oktatásban. Vezetéstudomány, (40) 1, 2-15. o.

Barakonyi K. (2010): A felsőoktatás versenyképességéről. Vezetéstudomány, (41) 12, 4-19. o.

Béchard, J-P. - Grégoire, D. (2005): Understanding Teaching Models in Entrepreneurship for Higher Education. In Kÿro, P. - Carrier, C. (eds.): The Dynamics of Learning Entrepreneurship in a Cross-Cultural University Context. Entrepreneurship Education Series 2, University of Tampere Research Center for Vocational and Professional Center, 104-134. o.

Braun, G. - Diensberg, C. (2007): Cultivating Entrepreneurial Regions - Cases and Studies from the Network Project 'Baltic Entrepreneurship Partners'. (BEPART), Universität Rostock.

Brown, R. (1990): Encouraging enterprise: Britain's graduate enterprise program. Journal of Small Business Management, 10, 71-77. o.

Brush, C. (1992): Research on women business owners: Past trends, new perspective and future directions. Entrepreneurship Theory and Practice, 4, 5-30. o.

Buzás N. (2004): A vállalkozói szellem szerepe a spin-off cégek alapításában. In Czagány L. - Garai L. (szerk.): A szociális identitás, az információ és a piac. JATEPress, Szeged, 257266. 0. 
Carayannis, E. G. - Barth, T. D. - Campbell, D. F. (2012): The Quintuple Helix innovation model: global warming as a challenge and driver for innovation. Journal of Innovation and Entrepreneurship, (1) 1, 1-12. o.

Carayannis, E. G. - Campbell, D. F. (2012): Mode 3 knowledge production in quadruple helix innovation systems. Springer, Berlin, 1-63. o.

Chamard, J. (1989): Public Education: Its Effect on Entrepreneurial Characteristics. Journal of Small Business and Entrepreneurship, 2, 23-30. o.

Chiesa, V. - Piccaluga, A. (2000): Exploitation and diffusion of public research: the case of academic spin-off companies in Italy. $R \& D$ Management, 30, 329-340. o.

Clark, B. (2001): The entrepreneurial university: New foundation for collegiality, autonomy, and achievement. Higher Education Management, 13, 9-24. o.

Crayford, J. - Fearon, C. - McLaughlin, H. - van Vuuren, W. (2012): Affirming entrepreneurial education: learning, employability and personal development. Industrial and Commercial Training, (44) 4, 187-193.o.

Csapó K. (2007): Vállalkozásoktatás diákvállalkozásokon keresztül - tapasztalatok a Budapesti Corvinus Egyetemről. Vezetéstudomány, (38) 4, 30-42. o.

Csapó K. (2010): Vállalkozásoktatás korszerű hazai kísérletei a Budapesti Corvinus Egyetemen. Vállalkozás és Innováció, (4) 1, 33-51. o.

Cuervo, Á. - Ribeiro, D. - Roig, S. (2007): Entrepreneurship: Concepts, Theory and Perspective. Introduction. In Cuervo, Á. - Ribeiro, D. - Roig, S. (eds.): Entrepreneurship: Concepts, Theory and Perspective. Springer. Berlin, 1-22. o.

Davidsson, P. - Delmar, F. - Wiklund, J. (2006): Entrepreneurship as Growth; Growth as Entrepreneurship". In Davidsson, P. - Delmar, F. - Wiklund, J. (eds): Entrepreneurship and the Growth of Firms. Edward Elgar, Cheltenham, 21-38. o.

Debackere, K. - Veugelers, R. (2005): The role of academic technology transfer organizations in improving industry science links. Research Policy, (34) 3, 321-342. o.

Donckels, R. (1991): Education and Entrepreneurship Experience from Secondary and University Education in Belgium. Journal of Small Business and Enterprise, 1, 35-42. o.

Draycott, M. - Rae, D. - Vause, K. (2011): The assessment of enterprise education in the secondary education sector: A new approach? Education + Training, 53, 673 - 691. o.

Dreisler, P. (2007): The Role of University Education in the Aarhus Region, Denmark In Braun, G. - Diensberg, C. (eds.): Cultivating Entrepreneurial Regions - Cases and Studies 
from the Network Project 'Baltic Entrepreneurship Partners', (BEPART). Universität Rostock

EC (1999): Sixth Periodic Report on the Social and Economic Situation and Development of Regions in the European Union. European Commission, Luxembourg.

EC (2003): Green Paper. Entrepreneurship in Europe. European Commission, Brussels.

EC (2013): 2013. évi éves növekedési jelentés. European Commission, Brüsszel.

Etzkowitz, H - Zhou, C. (2007): Regional innovation initiator: the entrepreneurial university in various triple helix models. Singapore Triple Helix VI Conference Theme Paper.

Etzkowitz, H (2004): The triple helix and the rise of the entrepreneurial university. In Grandin, K. - Wormbs, N. - Widmalm, S. (eds.): The science-industry nexus: History, policy, implications. Science History Publications, Sagamore Beach, 69-91.o.

Etzkowitz, H. - Dzisah, J. - Zhou, C (2007): The triple helix model of innovation. Universityindustry-government interaction. Asia Pacific Tech Monitor, 24, 14-23. o.

Etzkowitz, H. - Zhou, C. (2006): Triple Helix twins: innovation and sustainability. Science and Public Policy, 33, 77-83. o.

Fayolle, A. - Gailly, B. (2008): From craft to science: Teaching models and learning processes in entrepreneurship education. Journal of European Industrial Training, (32) 7, 569-593. o.

Fayolle, A. (2007): Essay on the nature of entrepreneurship education. In International Conference Entrepreneurship in United Europe-Challenges and Opportunities. 1-18.o.

Fayolle, A. (2009): Entrepreneurship Education in Europe: Trends and Challenges. Universities, innovation and entrepreneurship: good practice workshop.

Friedman, J. - Silberman J. (2003): University technology transfer: do incentives, management, and location matter? Technology Transfer, (28) 1, 17-30. o.

Gál Z. (2005): Az egyetemek szerepe a regionális innovációs hálózatokban. In Buzás N. (szerk.): Tudásmenedzsment és tudásalapú gazdaságfejlesztés. JATEPress, Szeged, 269292. o.

Gartner, W. (1988): „Who is an entrepreneur?” Is the wrong question. University of Illinois at Urbana-Champaign's Academy for Entrepreneurial Leadership Historical Research Reference in Entrepreneurship.

Gibb, A. (2011): Concepts into practice: meeting the challenge of development of entrepreneurship educators around an innovative paradigm: The case of the International 
Entrepreneurship Educators' Programme (IEEP). International Journal of Entrepreneurial Behaviour \& Research, (17) 2, 146-165.o.

Gibb, A. A. - Haskins, G. - Robertson, I. (2013): Leading the Entrepreneurial University: Meeting the Entrepreneurial Development Needs of Higher Education Institutions In: Altmann, A. - Ebersberger, B. (eds.): Universities in Change, Innovation, Technology, and Knowledge Management, Springer, New York, 9-45. o.

Gibb, A.A. - Haskins, G. - Robertson, I. (2009): Leading the entrepreneurial university. NCGE Policy Paper, October, Birmingham.

Gibb, A.A. (2002): In pursuit of a new entrepreneurship paradigm for learning: creative destruction, new values, new ways of doing things and new combinations of knowledge. International Journal of Management Reviews, (4) 3, 233-69. o.

Gjerding, A.N. - Cameron, S. - Wilderom, C. - Taylor, A. - Scheunert, K-J (2006): Twenty practices of an entrepreneurial university. High Education Management Policy, (18) 3, 128. 0 .

Gordon, I. - Hamilton, E. - Jack, S. (2012): A study of a university-led entrepreneurship education programme for small business owner/managers. Entrepreneurship \& Regional Development, (24) 9-10, 767-805. o.

Gorman, G. - Hanlon, D. - King, W. (1997): Some research perspectives on entrepreneurship education, enterprise education and education for small business management: a ten-year literature review. International Small Business Journal, 15, 56-77. o.

Gubik A. (2013) A magyar hallgatók vállalkozásindítási szándékát befolyásoló tényezők modellje. Vezetéstudomány, (44) 7-8, 19-29. o.

Guerrero, M., - Urbano, D. (2012): The development of an entrepreneurial university. The Journal of Technology Transfer, (37) 1, 43-74. o.

Henry, C. - Hill, F. - Leitch, C. (2005): Entrepreneurship education and training: can entrepreneurship be taught? Part II. Education and Training, 47, 158-169. o.

Hoskisson, R. E. - Covin, J. - Volberda, H. W. - Johnson, R. A. (2011): Revitalizing entrepreneurship: the search for new research opportunities. Journal of Management Studies. (48) 6, 1141-1168. o.

Imreh Sz. - Kosztopulosz A. - Imreh-Tóth M. (2013): Az akadémiai spin-off vállalkozások „akadálytérképe”. In Inzelt A. - Bajmócy Z. (szerk.): Innovációs rendszerek: Szereplők, kapcsolatok és intézmények. JATEPress, Szeged, 71-91. o. 
Imreh Sz. - Lukovics M. (2011): Vállalkozás alapítás és vállalkozóvá válás. Kutatási jelentés a „Tudáshasznosulást, tudástranszfert szolgáló eszköz- és feltételrendszer kialakítása, fejlesztése a Szegedi Tudományegyetemen és a Dél-alföldi Régióban” c. projekt keretein belül. SZTE GTK, Szeged.

Imreh-Tóth M- Imreh Sz. - Prónay Sz. - Vilmányi M. - Lukovics M. - Kovács P. (2012): Vállalkozásoktatás a felsőoktatásban: lehetőségek és remények. In Bajmócy Z. - Lengyel I. - Málovics Gy. (szerk.): Regionális innovációs képesség, versenyképesség és fenntarthatóság. JATEPress, Szeged, 239-250. o.

Imreh-Tóth M. - Bajmócy Z. - Imreh Sz. (2013): Vállalkozó hallgatók - Valóban reális jövőkép a vállalkozóvá válás? Vezetéstudomány, 7-8., 51-63.o

Inzelt A. (2010): Külföldi részvétel a hazai egyetemek és az ipar közötti együttműködésben. Közgazdasági Szemle, (57) 5, 431-456. o.

Jacob M. (2003): Entrepreneurial transformations in the Swedish university system: the case of Chalmers university of technology. Research Policy, (32) 9, 1555-1568. o.

Johnson, D. (2001): What is innovation and entrepreneurship? Lessons for larger organisations. Industrial and Commercial Training, 33, 135 - 140. o.

Jones, B. - Iredale, N. (2010): Enterprise education as pedagogy. Education+ Training, (52) 1, 7-19. o.

Kállay L. - Imreh Sz. (2004): A kis- és középvállalkozás-fejlesztés gazdaságtana. Aula, Budapest.

Kickul, J. - Fayolle, A. (2007): Cornerstones of change: revisiting and challenging new perspectives on research in entrepreneurship education. In Fayolle, A. (ed.): Handbook of Research in Entrepreneurship Education, Edward Elgar, Cheltenham, o.

Kim, .Y - Kim, W. - Yang, T. (2012): The effect of the triple helix system and habitat on regional entrepreneurship: Empirical evidence from the U.S. Research Policy, 41, 154-165. o.

Klein, P. G. - Bullock, J. B. (2006): Can entrepreneurship be taught? Journal of Agricultural and Applied Economics, (38) 2, 429-448.o.

Klofsten, M. (2000): Training entrepreneurship at universities: a Swedish case. Journal of European Industrial Training, 24, 337-44. o.

Krueger, N. F. (1993): The impact of prior entrepreneurial exposure on perceptions of new venture feasibility and desirability. Entrepreneurship Theory and Practice, 1, 5-21. o. 
Krueger, N. F. (2009): The microfoundations of entrepreneurial learning and education: the experiental essence of entrepreneurial cognition. In West, P.G. - Gatewood, E. J. - Shaver, K. G. (eds.): Handbook of University-wide Entrepreneurship Education. Edward Elgar, Cheltenham-Northampton, 35-59. o.

Kuratko, D. (2003): Entrepreneurship education: emerging trends and challenges for the 21st century. Coleman Foundation White Paper Series, Coleman Foundation, Chicago, IL.

Lange, J. E. - Marram, E. - Jawahar, A.S - Yong, W. - Bygrave, W. (2011): Does an entrepreneurship education have lasting value? A study of careers of 4,000 alumni. Frontiers of Entrepreneurship Research, 31, 210 - 224. o.

Lee, L., - Wong, P. K. (2007): Entrepreneurship Education-A Compendium of Related. Springer, New York, 79-105.o.

Lengyel B. (2005): Triple Helix kapcsolatok a tudásmenedzsment szemszögéből. In Buzás N. (szerk.) 2005: Tudásmenedzsment és tudásalapú gazdaságfejlesztés. SZTE Gazdaságtudományi Kar Közleményei. JATEPress, Szeged, 293-311. o.

Lengyel B. (2012): Tudásalapú regionális fejlödés. l'Harmattan. Budapest.

Lengyel I. (2000): A regionális versenyképességről. Közgazdasági Szemle, 12, 962-987. o.

Lengyel I. (2003): Verseny és területi fejlődés: térségek versenyképessége Magyarországon. JATEPress, Szeged.

Lengyel I. (2006): A Szegedi Tudományegyetem lehetőségei a tudásalapú helyi gazdaságfejlesztésben. In Máder B. - Rácz B. (szerk.): 85 éves a szegedi felsőoktatás. Szegedi Tudományegyetem, Szeged, 45-52. o.

Lengyel I. (2010): Regionális gazdaságfejlesztés. Akadémiai Kiadó, Budapest.

Leydesdorff, L. - Etzkowitz, H. (1998): The Triple Helix as a Model for Innovation Studies. Science and Public Policy, 25, 195-203. o.

Leydesdorff, L. (2000): The triple helix: an evolutionary model of innovations. Research Policy, 29, 243-255. o.

Lourenco, F. - Jayawarna, D. (2011): The effect of creativity on post-training outcomes in enterprise education. International Journal of Entrepreneurial Behaviour \& Research, 17, 224-244. o.

Lourenco, F. - Taylor, T. G. - Taylor, D. W. (2013): Integrating "education for entrepreneurship" in multiple faculties in "half-the-time" to enhance graduate entrepreneurship. Journal of Small Business and Enterprise Development, 20, 503-525. o. 
Lukovszki L. (2011): Vállalkozói személyiségjegyek - avagy mi teszi a vállalkozót? Vezetéstudomány, (42) 11, 16-30. o.

Lüthje, C. - Franke, N. (2002): Fostering entrepreneurship through university education and training: Lessons from Massachusetts Institute of Technology. European Academy of Management, 2nd Annual Conference on Innovative Research in Management, május 911., Stockholm.

Martin, B. - Etzkowitz, H. (2000): The origin and evolution of the university species. VEST, 13, 9-34. o

Matlay, H. (2005): Entrepreneurship education in UK business schools: Conceptual, contextual and policy considerations. Journal of Small Business and Enterprise Development, 12, 627 - 643. o.

Matlay, H. (2006): Researching entrepreneurship and education: Part 2: what is entrepreneurship education and does it matter? Education + Training, 48, 704 - 718. o.

Matlay, H. (2008): The impact of entrepreneurship education on entrepreneurial outcomes. Journal of Small Business and Enterprise Development, (15) 2, 382-396. o.

McCarthy, A. - Morris, P.J. - Winn, L. (1997): A new look at undergraduate entrepreneurship education mimeo, College of Business, Colorado State University, Fort Collins.

McMullan, W. - Long, W.A. (1985): Entrepreneurship education in the nineties. Journal of Business Venturing, (2) 3, 261-275. o.

Mendes, A. - Kehoe, C. (2009): Academic entrepreneurship: possibilities and pitfalls. In West, P.G. - Gatewood, E. J. - Shaver, K. G. (eds.): Handbook of University-wide Entrepreneurship Education. Edward Elgar, Cheltenham-Northampton, 73-94. o.

Mihályi I. (2001): Vállalkozási ismeretek oktatása Európában. Új Pedagógiai Szemle, (5) 12: 81-89. o.

Mitra, J. - Manimala, M. J. (2008): Higher education's role in entrepreneurship and economic development. In Potter, J. (ed.): Entrepreneurship and Higher Education. OECD, Paris, 45-64. o.

Mwasalwiba, E. S. (2010): Entrepreneurship education: a review of its objectives, education methods, and impact indicators. Education+ Training, 52, 20-47.o.

Nicolaou, N., - Shane, S. (2009): Can genetic factors influence the likelihood of engaging in entrepreneurial activity? Journal of Business Venturing, (24) 1, 1-22. o. 
Novotny Á. (2011): Egyetemi kutatók tudományos vállalkozói attitüdje - egy empirikus kutatás háttere, kérdései, módszere és néhány eredménye. Marketing \& Menedzsment, 45, 44-54. o.

OECD (2003): Entrepreneurship and Local Economic Development. OECD, Paris.

OECD (2012): A Guiding Framework for Entrepreneurial Universities. OECD, Paris.

Parker (2007): The Life Cycle of Entrepreneurial Ventures. Springer, Berlin.

Peńa, V. - Transue, M. - Riggieri, A. - Shipp, S. - Van Atta, R. (2010): A Survey of Entrepreneurship Education Initiatives. Science\&technology Policy Institute, Washigton.

Pfeiffer, E. (1997): What MIT learned from Stanford, Forbes, August 25, New York. 59.

Pittaway, L. - Hannon, P. - Gibb, A. - Thompson, J. (2009): Assessment practice in enterprise education. International Journal of Entrepreneurial Behaviour and Research, 15, 71-93. o

Potter, J. (2008): Entrepreneurship and Higher Education. OECD, Paris.

Propis, L. (2002): Types of Innovation and Interfirm Co-operation. Entrepreneurship \& Regional Development, 14, 337-353. o.

Román Z. (2006): A vállalkozás oktatása a felsőoktatatásban. Vezetéstudomány, 37, 2-9. o.

Saks, N.T. - Gaglio, C.M. (2002): Can Opportunity Identification Be Taught? Journal of Enterprising Culture, 4, 313-347. o.

Shane, S. - Venkataraman, S. (2000): The promise of entrepreneurship as a field of research. Academy of Management Review, (25) 1, 217 - 226. o.

Shepherd, D. A., - Douglas, E. J. (1997): Is management education developing, or killing, the entrepreneurial spirit. In Proceedings of the 1997 USASBE Annual National Conference Entrepreneurship: The Engine of Global Economic Development, San Francisco, California.

Solomon, G. (2007): An examination of entrepreneurship education in the United States. Journal of Small Business and Enterprise Development, 14, 168-182. o.

Stel, van A. (2006): Empirical Analysis of Entrepreneurship and Economic Growth. Springer, Berlin.

Stenberg, R. (2000): Innovation Networks and Regional Development - Evidence from European Regional Survey (ERIS). European Planning Studies, (8) 4, 389-407. o.

Sternberg, R. - Wennekers, S. (2005): Determinants and effects of new business creation using global entrepreneurship monitor data. Small Business Economics, (24) 3, 193-203. o.

Stevenson, H. - Jarillo, J. (1990): A paradigm of entrepreneurship: entrepreneurial management. Strategic Management Journal, 11, 17-27.o. 
Szerb L. - Lukovszki L. (2013): A magyar egyetemi hallgatók vállalkozási attitüdjei és az attitüdöket befolyásoló tényezők elemzése a GUESSS felmérés alapján. Vezetéstudomány, (44) 7-8, 30-40. o.

Szerb L. - Márkus G. (2007a): Vállalkozói környezet és vállalkozásoktatás nyolc magyar egyetemen, nemzetközi összehasonlításban, hallgatói vélemények alapján. Vezetéstudomány, (37) 6, 29-41. o.

Szerb L. - Márkus G. (2007b): A felsőoktatási környezet hatása a vállalkozói életpálya választására (nemzetközi összehasonlító elemzés). Közgazdasági Szemle, 3, 248-273. o.

Szirmai P. - Csapó K. (2006): Gyakorlati vállalkozásoktatás - Diákvállalkozások támogatása a Budapesti Corvinus Egyetemen. Új Pedagógiai Szemle, 10, 72-83. o.

Todorovic, Z. W. (2004): The framework of static and dynamic components: an examination of entrepreneurial orientation and university ability to teach entrepreneurship. Journal of Small Business and Entrepreneurship, 17-45. o.

Vas Zs. (2012): Tudásalapú gazdaság és társadalom kiteljesedése: A Triple Helix továbbgondolása - a Quadruple és Quintuple Helix. In Rechnitzer J. - Rácz Sz. (szerk.): Dialógus a regionális tudományról. SZIE Regionális- és Gazdaságtudományi Doktori Iskola, Györ, 198-206. o.

Vesper, K. - McMullan, E.W. (1997): New venture scholarship versus practice: When entrepreneurship academics try the real things as applied research. Technovation, 7, 349358. o.

Vesper, K.H. - Gartner,W.B. (1997): Measuring progress in entrepreneurship education. Journal of Business Venturing, 12, 403-21. o.

Vilmányi M. - Kovács P. (2008): Egyetemi - ipari együttmüködések teljesítménye és lehetséges vizsgálati módszere. In Lengyel I. - Lukovics, M. (szerk.): Kérdőjelek a régiók gazdasági fejlődésében. JATEPress, Szeged, 62-90. o.

Vilmányi M. (2011): Egyetemi-ipari együttmüködések a kapcsolatmarketing nézőpontjából. Vezetéstudomány, (42) 1, 52-63. o.

Wennekers, S., - Thurik, R. (1999): Linking entrepreneurship and economic growth. Small Business Economics, (13) 1, 27-56.o.

Wilson, K. (2008): Entrepreneurship education in Europe. In Potter, J. (ed.) Entrepreneurship and higher education. OECD, Paris, 119-137. o.

Wissema, J. G. (2009): Towards the third generation university. Managing the university in transition. Edward Elgar, Northampton. 
Wong, P.K. - Ho, Y.P. - Autio, E. (2005): Entrepreneurship, Innovation and Economic Growth: Evidence from GEM data. Small Business Economics, 3, 335 -350. o.

Youtie J. - Shapira P (2008): Building an innovation hub: a case study of the transformation of university roles in regional technological and economic development. Research Policy, 37, 1188-1204. o.

Zahra, S. - Welter, F. (2008): Entrepreneurship Education for Central, Eastern and Southeastern Europe. In Potter, J. (ed.) Entrepreneurship and higher education. OECD, Paris, 165-192.o.

Zeithamil, C.P. - Rice, G.H. (1987): Entrepreneurship/Small Business Education in American Universities. Journal of Small Business Management, 1, 44-50. o. 


\section{Mellékletek}

\section{1. sz. melléklet: Vizsgált intézmények az USA-ban}

\section{Babson College}

Az 1919-ben alapított, üzleti képzéseket kínáló magánegyetem, székhelye Massachusetts államban Wellesleyben található. A vállalkozásoktatás terén kiemelkedő helyen rangsorolják (legjobb MBA programok: 20 egymást követő éven át I. hely, legjobb alapfokú programok: 17 éve I. helyen). Évről évre szintén előkelő helyet szerez a legjobban megfizetett végzett hallgatók kategóriájában (megelőzve ezzel több „Ivy League” egyetemet is: pl. Stanford, MIT, Harvard, Columbia).

Vezérelvüknek („A tapasztalat a legjobb tanár”) megfelelően a tantestület többségét egyetemi oktatók helyett üzletemberek, vállalkozók alkotják.

\section{MóDSZEREK:}

- Interdiszciplináris oktatás

- Tapasztalat alapú tanítás

- Analitikus gondolkodásmód, kreativitás, üzleti gyakorlat fejlesztése

- Önállóság, kapcsolatépítés, tervezés-szervezés fejlesztése: hallgatókkal szerveztetnek konferenciákat, fórumokat, versenyeket

- eTanulás, távoktatás alkalmazása

- Az egyetem együttmüködések keretében, valamint önállóan is folyamatosan kutatja, fejleszti a vállalkozás oktatás metodikáját (pedagógia, tantervek, tudásátadási csatornák).

\section{SzAKоK:}

- Alap: Sokféle, saját igény szerint bejárható ösvény van, emiatt nem olyan egyértelmü különálló szakokat definiálni, mint a hazai bolognai rendszerben (erről árulkodik a 27 féle specializáció is). Pl. Számvitel, Közgazdaságtan, Pénzügy, IT menedzsment, Nemzetközi üzleti környezet, Vezetés, Jogi tanulmányok, Ingatlanügyek, Üzleti tervezés, elemzés, irányítás, stb. 
- Mester:

○ MBA (Master of Business Administration): Hagyományos MBA program. Egyaránt biztosítanak egy és két éves, valamint levelező tagozatot is.

○ MSM (Master of Science in Management in Entrepreneurial Leadership): Vállalkozói képzés, de nagyobb hangsúlyt kap a közgazdaságtan, menedzsment, nemzetközi gyakorlatok területe. Nem üzleti végzettségüek is jelentkezhetnek rá.

○ MSA (Master of Science in Accounting): Könyvelésre specializálódott üzleti képzés.

- Igazgatói/Felsővezetői képzések: Néhány napos, egy-két hetes időtartamú, specializált, intenzív programok. Témakörök például: BioFarma, IT, Belső vezetés, Női vállalkozói tréning, Tőkebevonás, Üzleti analitika, stb.

FONTOSABB KURZUSOK (Vállalkozás specializációban):

- A menedzsment és vállalkozás alapjai (Foundations of Management and Entrepreneurship)

- Lehetőség és vállalkozás (Entrepreneurship and Opportunity)

- Marketing vállalkozóknak (Marketing for Entrepreneurs)

- Növekedési stratégiák (Venture Growth Strategies)

- Technológiai vállalkozások (New Technology Ventures)

- Tőkebevonás: kockázati tőke, üzleti angyalok, inkubátorok (Raising Money: VC, Angels \& Incubators)

- Kisvállalkozások felvásárlása (Buying a Small Business)

- Vállalkozások az egészségügyi technológia területén (Entrepreneurship in Healthcare Technology)

- Jogi alapismeretek vállalkozóknak (Law for Entrepreneurs)

- Fúzió és felvásárlás a vállalkozók szemével (M \& A for Entrepreneurs)

- Nagyvállalati vállalkozástan (Corporate Entrepreneurship)

- Családi vállalkozások jellegzetességei (Essential Practices in Family Entrepreneurship) 


\section{STRATÉGIA:}

1. Entrepreneurial Thought and Action / Vállalkozói Gondolkodás és Cselekvés A hallgatókkal bizonyos szinten megismertetik, ezen túlmenően pedig megtanítják nekik megismerni a társadalom és gazdaság mélyebb összefüggéseit. Ezzel olyan kölcsönhatásokra épülő integrált környezetként ismerik meg a világot, melyben könnyedén azonosíthatnak problémákat, és lehetőségeket teremthetnek annak kihívásaiból.

Emellett felkészítik őket arra, miként reagáljanak a különféle bizonytalanságokra és viszontagságokra, melyek egy dinamikusan változó piacnak mindig sajátjai.

\section{Entrepreneurship of All Kinds / Vállalkozó Bárki Lehet}

Vállalkozókról gyakran StartUp-okra, kockázati tőkére, üzleti inkubátorokra asszociálunk.

A Babson College tolmácsolásában sokkal szélesebb körben kell tekinteni a vállalkozókra. Függetlenül tehát attól, hogy ki milyen iparágban dolgozik, mekkora a vállalkozása, globális, vagy helyi jelentőségü üzletről van-e szó, fontos megérteni, hogy a vállalkozó az vállalkozó. Ugyanolyan általános, belső motivációkkal mindannyian: úgy használják tudásukat és erőforrásaikat, hogy fejlődjenek, és elérjék kitüzött céljaikat.

Ebből fakadóan ezen egyetem képzései nagyon népszerủek, hiszen potenciálisan mindenkinek kínálják őket (nemcsak high-tech vállalkozóknak).

3. Több szem többet lát

Igyekeznek lehetőleg minél több országból, minél változatosabb háttérrel rendelkező vállalkozókat bevonni az oktatásba. illetve a gyakorlatba, így olyan kollektív tudásbázist teremtenek, mely tovább növeli versenyelőnyüket.

4. Vállalkozás-oktatási szolgáltatások biztosítása

Különféle igényeket kielégítő, a megrendelő szükségleteire szabott programokat biztosítanak akár távoli országokba is. Az így szolgáltatásként értékesített tanfolyamok, projektek bevételét az egyetemi oktatásba, fejlesztésbe forgatják vissza. 


\section{University of Houston - Bauer College of Business}

1927-ben alapított állami egyetem, legnépszerübb képzései üzleti és biológiai tudományokhoz köthetők. Székhelye Texas államban, Houstonban található. Rangsorolását tekintve alapfokú vállalkozói képzések terén 2007 óta a három legjobb amerikai egyetem között szerepel. Ezen felül az elmúlt években rendre első helyen végez nemzeti szintü üzleti terv készítő versenyeken.

A Babsonhoz hasonlóan a tantestület többségét itt is üzletemberek, vállalkozók alkotják, valamivel több pedagógiai, egyetemi háttérismerettel.

\section{MóDSZEREK:}

- Intenzív, minőségi oktatás (35-45 hallgató évente egy szakon)

- Logikus, funkció-központú tantervi felépítés (lásd: BBA)

- Cross-functional teaching: akadémiai elmélet - üzleti gyakorlat összehozása oly módon, hogy mindkettőt egy közös cél vezérli: a jövő vállalkozóinak kinevelése

- Enrichment programs: campuson kívüli kötetlenebb, közösségi programok

\section{SZAKOK:}

- Alap:

○ BBA (Bachelor of Business Administration) in Entrepreneurship: Vállalkozástan központú, funkció alapon lépcsőzetesen egymásra épített modulokból álló képzés. A képzés egy, az egész vállalkozói folyamatot áttekintő kurzussal indul, ezután következik az alegységek kibontása: Bevételek, Kiadások, Tőke, Üzleti terv, Kivitelezés kurzusok.

○ Certificate in Corporate Entrepreneurship: Célja nagyvállalati vállalkozástan oktatása. A képzés a BBA-hoz hasonló áttekintő kurzussal indul, melyet nagyvállalati vállalkozástan követ (milyen szempontok/irányelvek mentén érdemes haladni egy már létező, müködő nagyvállalkozás esetében), majd meghívott sikeres vállalkozók által tartott szemináriumok (Distinguished Entrepreneur Speaker Series) zárják le. 
- Mester:

○ MBA (Master of Business Administration): Hagyományos MBA képzés, elérhető 18 és 24 hónapos formában. Egyik MBA programjuk sajátja, hogy egy választott iparág igényeihez igazodva folytatnak szakirányú képzést (pl.:energia szektor).

○ EMBA (Global Leadership Executive MBA): Végzett hallgatóknak, felsővezetőknek szóló, 18 és 22 hónapos „levelező” tagozatos, specializált képzés. Kiemelt hangsúly a menedzseri készségek fejlesztésén. Szintén lehetséges energiaipari szakosodás.

○ MS Finance: Pénzügy mesterképzés

○ MS Accountancy: Számvitel mesterképzés

FONTOSABB KuRZUSOK:

- Vállalkozástan: áttekintő kurzus (Entrepreneurship Overview)

- Intrapreneurship/Nagyvállalati vállalkozástan (Corporate Entrepreneurship)

- Vállalkozói stratégiák és szempontok (Entrepreneurial Strategy \& Perspectives)

- Üzleti tervezés, vezetés (Business planning, leadership)

- Tárgyalástechnika (Negotiation)

- Vállalkozói gondolkodás, ötletgenerálás (Entrepreneurial thinking, idea generation)

- Szervezeti magatartás és menedzsment (Organizational Behavior and Management)

- Üzleti etika (Business Ethics)

- Termelés és múködés menedzsment (Production and Operations Management)

- Információs rendszerek a menedzsment szolgálatában (Management Information Systems)

- Üzleti kommunikáció és etikus érvelés (Business Communication and Ethical Reasoning)

\section{STRATÉGIA:}

1. Enrichment Programs / „Élményjavító” és informális programok Javarészt a következők alkotják az üzleti, gyakorlati részt: 
- Meghívott előadók (vállalkozók) által tartott prezentációk (az iskolapad helyett példa a való világból)

- „Ebédelj egy vállalkozóval!” = kiscsoportos kötetlen beszélgetés ebéd, vacsora keretében

- Kerekasztal mühelymunkák

- Mentoráló programok

- Próbaszituációk, „challengelés” (kockázati tőkéssel/magas rangú vezetőkkel történö tárgyalás)

- Üzleti terv készítő verseny

- Egy hétvégés csoportos elvonulások diákoknak, otthoni környezetbe ${ }^{17}$

- 12-14 hetes szakmai gyakorlati lehetőség egy vezérigazgató mellett

- Egy-két napos céglátogatások

2. Részvétel „outreach” tevékenységekben

Az egyetem ilyen jellegü müködése közösségi szolgálaton keresztül tanítja meg: a hallgatókat a társadalmi felelősségvállalásra; az érintetteket: a vállalkozások fontosságára, gazdaságban betöltött kiemelkedő szerepére. Nem utolsó sorban pedig az egyetemnek is jó reklám.

\section{Versenyeztetés}

Különféle versenyeken (pl.: Wolffest, 3 Day Startup, Cougar pitch ${ }^{18}$ ) való részvétellel motiválják hallgatóikat a jobb teljesítményre. Ezzel az egyetem hírnevét is növelik.

Összességében a Houstoni Egyetem a Babsonhoz képest jobban törekszik kötetlenebb, informális, élmény alapú kapcsolatok kialakítására a hallgatók között.

\footnotetext{
17 A hallgatók kötetlenül beszélhetik meg álmaikat, karrierterveiket egymással, emellett tudatosítják a hallgatókban, hogy a vállalkozó életforma azzal jár, hogy haza kell vinni a munkát.

${ }^{18}$ Wolff Center for Entrepreneurship által hirdetett verseny, amelynek lényege, hogy aki képes 2 perc alatt meggyőzni a zsürit az ötletével, 1000 dollárt nyer.
} 


\section{University of Michigan - Ross School of Business}

1817-ben alapított állami kutatóegyetem, székhelye Ann Arborban, Michigan államban található. Ez az egyetem igazi nagypályás. Hozzávetőlegesen 45000 hallgatóval, 6500 egyetemi oktatóval, 3000 kurzussal büszkélkedhet. 95 olyan mesterképzést ajánl, mely az amerikai nemzeti listán az első tíz között szerepel. Ezen felül állami egyetemek közül ők költik a legnagyobb összeget kutatásra (1,3 Mrd dollár 2012-ben).

Üzleti képzéseiért a „Ross School of Business” felel. Az Iskola az elmúlt 4 évben az első öt között szerepelt, majd a 2013-ban 1. helyet nyert el a legjobb vállalkozói mesterképzések kategóriában. Az oktatás fókuszában az üzletfejlesztés áll: Hogyan csinálj egy ötletből vagy találmányból életképes céget?

A vállalkozóra erőforrás-allokálóként tekintenek, aki tőkéből és ötletből, megfelelő kombinálással erős céget hoz létre. Ezek szerint a siker záloga az allokálás technikája, a know-how.

\section{MóDSZEREK:}

- Cselekvés alapú tanítás (Action-based learning) ${ }^{19}$

- Magas szintü testreszabott képzések felsővezetők részére.

- Ipar-egyetem erős, és tudatos összekötése

\section{SzAKOK:}

- Alap:

○ BBA (Bachelor of Business Administration): Magas szintü BBA képzés, de elsősorban nem erről híresek.

\section{- Mester:}

○ MBA (Master of Business Administration): 2 éves MBA képzés, nappali és esti tagozaton egyaránt elérhető.

\footnotetext{
19 "Action-based learning is based on the premise that there is no learning without action and no sober and deliberate action without learning." (Pedler, 1991).
} 
○ EMBA (Executive MBA): Felsővezetőknek szóló, speciális MBA képzés. Hangsúly a menedzseri készségek fejlesztésén van, ezen belül is kiemelt terület a stratégiai tervezés. Ezen kívül a résztvevőket megtanítják, hogyan tárgyaljanak befektetőkkel, hogyan kommunikálják magukat az egyes testületek vagy a média felé.

○ Global MBA: Célzott program olyan menedzserek részére, akiket az öket foglalkoztató vállalat küld továbbképzésre. Ennek keretében nemcsak pénzüggyel, marketinggel, vállalati stratégiával és vállalkozói tudományokkal kapcsolatos ismereteiket bővítik, de lehetőségük van egyetemi és ipari szereplőkkel is kapcsolatok kialakítására.

○ MM (Master of Management): 10 hónapos menedzsment program, mely üzleti alapképzéssel nem rendelkezőknek ad alapozó, üzleti ismereteket.

- MACC (Master of Accounting): Szintén 10 hónapos képzés. Fő eleme a könyvelés, de választható kurzusokon keresztül a hallgató egyéni karriertervei szerint kiegészítheti alaptantervét. Így olyan sokoldalú képesítést szerezhet, mely túllép a pénzügy, számvitel, menedzsment hagyományos - elkülönült értelmezésén; és egy integráltabb, munkaerő piaci igényeknek jobban megfelelö, alkalmazott tudásra tehet szert.

○ MSCM (Master of Supply Chain Management): 1 éves képzés, ellátásiláncmenedzsmentre specializálódva.M

○ MsE (Master of Entrepreneurship): Az egyetem Üzleti és Mérnöki Iskolájának közös, 1 éves programja. A képzés célja olyan vállalkozók kinevelése, akik magas technológiai szektorba tartozó vállalkozásokat hoznak létre.

\section{FONTOSABB KURZUSOK:}

- MAP (Multidisciplinary Action Projects): 2 hónapos intenzív projektmunka, mely során a hallgatók 4-6 fős csapatokban együtt dolgozva, egy közremüködő szponzor szervezet üzleti kihívásaira keresnek megoldást. A kurzus párhuzamba állítható a Babson College „Foundations of Management and Entrepreneurship” és a University of Houston „Wolffest” nevü programjaival. 
- ExecMAP (Executive Multidisciplinary Action Projects): Az előbb említett programhoz hasonló, kiemelt hangsúlyt fektetve a nemzetközi tapasztalatszerzésre.

- A jog vállalkozásban betöltött szerepe (Legal Environment of Business)

- Növekedési stratégiák (Strategies for Growth)

- Stratégiai gondolkodás és elemzés (Strategic Thinking and Competitive Analysis)

- A makroökonómia hatása a vállalkozásokra (Macroeconomics Environment of Business)

- Innováció menedzsment (New Product and Innovation Management)

- Kockázati tőke (Venture Capital)

- Magántőke (Private Equity)

- Betekintés különböző befektetői alapkezelők müködése (Wolverine Venture Fund, Zell Lurie Commercialization Fund, Social Venture Fund)

- Biotechnológiai eredetü gyógyszerek az üzlet világában (Commercialization of Biomedicine)

- Társadalmi felelősségvállalás (Corporate Social Responsibility)

\section{STRATÉGIA:}

1. Az egytem, mint a gazdasági fejlődés katalizátora

Az egyetem fontos szerepet játszott/játszik Michigan állam high-tech és üzleti szférába emelésén. Így a korábbi „rozsdaövezet” egyik nagy központja mára már vállalkozók és kockázati tőke kezelő cégek közkedvelt célpontjává vált. Tudatos képzésfejlesztéssel, alapítványok, inkubátorok létrehozásával, valamint az ipari szereplők bevonásával olyan támogató, vállalkozói közeget teremtettek, mely nagyban segíti a fiatalok törekvéseit, gyorsabb, könnyebb utat biztosítva cégek indításának és müködtetésének.

Mellékesen a korai fellendülés annak is volt köszönhető, hogy a recesszióval járó foglalkoztatás-visszaesés következtében a nagy mennyiségü képzett, de nem lekötött munkaerő - a szükségtől vezérleve - elkezdett új vállalkozásokban gondolkozni, melyekben meglehetősen jól helytálltak.

2. A kulturális berögződést megfelelő pedagógiával lehet fejleszteni

Már az iskolapadban megtanítják a hallgatókat arra, hogy ne féljenek kísérletezni, ne féljenek újat alkotni, mert bizony a „,bukás is a siker része.” Az ilyen jellegü kulturális 
támogatás már akkor nagyon sokat tud adni a jövőbeli vállalkozónak, mikor vállalkozása még csak elképzelésként létezik.

3. „The school gave us a laboratory to practice entrepreneurship safely.” /Grace Hsia/ Az iskola életszerü - de viszonylag kockázatoktól mentes - teret biztosít a vállalkozás gyakorlásához. Úgy tünik ez a gyakorlat mindegyik üzleti iskola sajátja. Mivel a vállalkozás mikéntjét leginkább gyakorlással lehet elsajátítani, kiemelten fontos, hogy az oktatás ne csak elméletet és esettanulmányokat; de valós, tapasztalaton alapuló lehetőségeket is kínáljon.

4. Kapcsolatok: az emberi erőforrás óriási jelentősége egy vállalkozói környezetben

Befutott vállalkozók interjúztatása során többen is kiemelték a kapcsolatok fontosságát. Legyenek azok formálisak, vagy informálisak, a hasonló gondolkodású emberekkel (vállalkozókkal) való kapcsolattartás és kommunikáció a siker lényegi eleme. E láthatatlan hálózat olyan táptalajként viselkedik, mely olyan erőforrásokkal képes ellátni egy vállalkozót, amilyenekre vállalkozása elején még nem is gondolt. Kölcsönösen előnyös kapcsolatokra épülve így olyan szimbiotikus rendszer alakul ki, mely egyszerre teremti a lehetőségeket és használja is őket; miközben újabb lehetőségeket teremt, melyeket ismét valamelyik szereplő hasznosít. Ilyen módon az egyéni tudás és tapasztalat kollektív értékké válik, mely egy gravitációs erőtérhez hasonlóan annál erösebb lesz, minél nagyobb tömeg alkotja. Ha sikerül egy-egy ilyen vállalkozói gócpontot kialakítani, az hosszú távon egyre erősebben fogja vonzani mindazt, ami egy támogató vállalkozói környezethez kell: tőke, tudás, ipar, ingatlan, egyéb szolgáltatások.

5. Helyben megtermelt tudás hasznosítása

Lévén, hogy az üzleti iskola egy kutatóegyetemhez tartozik, igyekeznek az itt generált tudást minél nagyobb mértékben kommerciálisan is hasznosítani. Ehhez egyetemen belüli kooperáció szükséges, mely magában foglalja kutatók vállalkozói hajlandóságának növelését, illetve üzleti végzettségüek oktatását a tudományos vívmányokban rejlő lehetőségek hasznosításáról. 
6. Intrapreneurship erősítése

Intrapreneur-ökön olyan vállalkozói attitüddel rendelkező egyéneket értünk, akik maguk is foglalkozatásban vannak egy nagyvállalaton belül. Sok vállalkozó innen alapít új céget, míg mások a nagyvállalat ranglétráját járják be. Kreatív, újító hozzáállásuk miatt egyre keresettebbek az ilyen emberek, mely azt is jelenti, hogy a nem kifejezetten vállalkozónak készülő egyének is igényt tarthatnak magas szintű vállalkozói képzésekre. Ezáltal az egyetem a toborzás idején nem csupán a hagyományosan vállalkozni vágyók réteget célozhatja meg, hanem egy olyan átmeneti csoportot is, akik fél úton vannak munkavállalók és munkaadók között.

\section{Harvard University Harvard Business School}

1636-ban alapított magán kutatóegyetem, székhelye Cambridge-ben, Massachusetts államban található és 1908-ban jött létre az Üzleti Iskoláj. A University of Michigan és a Babson College után rangsorban ők kínálják a 3. legnívósabb vállalkozói mesterképzéseket. Esetükben a tantestület többsége azonban nem kifejezetten vállalati szektorban tevékenykedik.

\section{MóDSZEREK:}

- Felelősségtudat, tettlegesség, önmegvalósítás: „Te leszel az, aki megcsinálja, nem más!”

- Globális fókusz: kurzusok 30-40\%-a nemzetközi trendekből merít

- Sokoldalú, gyakorlatias tanítás: Case Method, FIELD (Field Immersion Experiences for Leadership Development)

- Innovation Lab: hallgatóknak nyújt segítséget vállalkozói alapok oktatásától kezdve egészen üzleti inkubálásig.

- Információ; oktatási- és egyéb szolgáltatások biztosítása: pl. publikációk, folyóiratok elérhetősége, szakvélemények készítése igény szerint, vállalati ügyfeleknek még toborzó szolgáltatás is: munkaerőt kereső cégek és diákok, alumni (munkaerő) összekötése

- Kapcsolati tőke generálása (jelen hallgatók) és aktivizálása (alumni) 


\section{SzAKOK:}

- Mester: MBA (Master of Business Administration): 2 éves MBA képzés. A hallgatók az első évben teljesítik a háromelemü FIELD kurzust; a második év jobbára a szabadon választhatókról szól.

- Igazgatói/Felsővezetői képzések: Néhány napos, egy-két hetes időtartamú, specializált, intenzív programok.

\section{FonTOSABB KuRZUSOK:}

- Pénzügy és ellenőrzés (Financial Reporting and Control)

- Vezetés és szervezeti magatartás (Leadership \& Organizational Behavior)

- Vállalkozás, kormányzat, nemzetközi közgazdaságtan (Business, Government, and the International Economy)

- A vállalatvezetés jogi, etikai és gazdasági vonatkozásai (Leadership and Corporate Accountability)

- Energiaszektor és geopolitika (The Energy Business and Geopolitics)

- Élettudományi vállalkozások indítása (Building Life Science Businesses)

- A vállalati szektor múltja és jövője az Egyesült Államokban (The Coming of Managerial Capitalism: The United States)

- Vállalkozók, akik megváltoztatták a Világot (Creative High-Impact Ventures: Entrepreneurs Who Changed The World)

- Az alapító dilemmái (Founders' Dilemmas)

\section{STRATÉGIA:}

1. Az egész több mint a részek összessége

Jó példa erre a szinergiára az Orvosi és az Üzleti Iskola együttműködése. A két intézet erősségeit ötvözve kialakították a tökéletes élettudományi vállalkozás receptjét: magas szintủ alkalmazott kutatás + üzleti know-how = transzformatív, sikeres, globális hatású biotechnológiai vállalkozás. pl.: Vaxess Technologies: hőstabil vakcina-technológia. 
2. Globális fókusz

Az oktatás egészét áthatja a nemzetközi légkör, a sokoldalú szempontok figyelembe vétele. Alapelv, hogy a Harvard nem csak az amerikai piacra neveli a hallgatóit.

3. Egyetemi kapcsolatrendszer erőteljes használata

Az egyetem valósággal megél a nevéböl, pontosabban a Harvard köré épült brandből. Az intézmény egész módszertana és stratégiája tükrözi azt a magas szintű minőséget, amit a Harvard név fémjelez. E közösségbe tartoznak a jelenlegi oktatók, hallgatók, és a már végzett 80000 alumni. Élve ezzel a potenciállal ahol csak lehet, hangsúlyozzák az egyetem által nyerhető kapcsolati tőke felbecsülhetetlen értékét.

4. Soknézőpontos, gyakorlati oktatás

- Case Method: A hallgatók e kurzuson mindannyian döntéshozó személyként vesznek részt.

Mire a hallgatók elvégzik a két éves MBA programot, több mint 500 ilyen esettanulmányon vesznek részt. A csapattársi viszonyból eredően pedig potenciális 200 vezető beosztású kollégájuk lesz majd világszerte, akik bármikor segíthetnek nekik jobb döntéseket hozni, jobb vezetőnek lenni. A felbecsülhetetlen értékü kapcsolati tőke mellett, e módszerben a hallgatók valójában a tudás, a nézőpontok, a szakértelem magas koncentrációját fizetik meg.

- FIELD (Field Immersion Experiences for Leadership Development): Három részból álló gyakorlati kurzus.

Az első szakasz az egyéni képességek feltárásáról szól. Kisebb csoportokban szituációs feladatokkal fedik fel az egyes hallgatók erősségeit, gyengeségeit.

A második szakaszban egy nagyvállalat piaci terjeszkedéssel kapcsolatos törekvéseibe segítenek be (termék/szolgáltatásfejlesztés). Ez csereprogramokon keresztül, potenciális ügyfelekkel való kapcsolatfelvétel útján zajlik. Itt betekintést nyernek abba, milyen információkra lehet szert tenni személyes interjún alapuló piackutatással, és hogy ezen információk birtokában mennyire más következtetésre jutnak, mint ha csak fejben játszották volna le a fejlesztési koncepciót. Ezen felül kiemelt jelentősége van a kulturális beágyazottságnak is. 
A harmadik, lezáró szakaszban a korábbi egyetemek példájához hasonlóan mikrovállalkozást kell indítaniuk (esetükben két hónap áll rendelkezésre). E szakasz végén kiemelik a legsikeresebb vállalkozásokat, tehát egyfajta versenyként is felfogható.

Horizontálisan pedig a University of Michigan módszeréhez hasonlóan végig jelen van a ciklikusan iterált kísérletezés: learning-doig-reflecting

\section{University of Southern California Marshall School of Business}

1880-ban alapított magán, de nonprofit egyetem. Székhelye Los Angelesben, Kaliforniában található. Az üzleti képzések oktatásáért a Marshall Üzleti Iskola felelős, mely 1920 óta müködik.Vállalkozói alapképzések oktatásában a Princeton Review 3. helyre rangsorolja, a Babson College és a University of Houston után. Mesterképzések oktatásában 10. helyen szerepel.

A tantestület legnagyobb hányadát itt is vállalkozók alkotják. Úgy tünik a rangsorolt egyetemek között megfigyelhető egy általános tendencia, miszerint az alapképzések oktatásában főként vállalkozók vesznek részt, míg a mesterképzések terén a vállalkozók mellett nagy arányban találhatók meg egyetemi oktatók, professzorok is.

\section{MóDSZEREK:}

- Kis létszámú osztályok (átlag: 23 fö)

- Networking szervezetek, fórumok (EVMA, e-Club)

- Kétirányú kapcsolatok létrehozása ipari, vállalati szereplőkkel

- Kombinálható tanulmányi ösvények

- Tapasztalati tanulás; játékosan modellezve: Experential Learning Center

- WBB: World Bachelor in Business

- Summer Business Program

- Certificate Programs: kiegészítő, oklevelet adó tanulmányok

\section{SZAKOK:}

- Alap:

○ BSBA (Bachelor of Science in Business Administration): A viszonylag hosszú (4 éves) üzleti képzés alatt lehetőség van a tudományterületek kombinálására 
(major, minor), sőt kettős major (és egy minor) végzettség is szerezhető. Így akár interdiszciplináris irányba is történhet a specializáció.

○ BSA (Bachelor of Science in Accounting): Számvitelre specializálódott, szintén 4 éves üzleti képzés. E két programban horizontálisan szerepel a globális fókusz: 7-10 napos tanulmányutak, kirándulások, melyek során külföldi vállalatvezetőket látogatnak meg.

○ WBB (World Bachelor in Business): Egészen különleges kialakítású, szintén 4 éves üzleti képzés. Az első évfolyam 2013 őszén indult. A technika lényege, hogy a hallgatók évről évre más egyetemre járva kapnak oktatást. Az első évet Los Angelesben, az USA-ban, a második évet Hong Kongban, Kínában, a harmadik évet Milánóban, Olaszországban töltik. A negyedik évről a hallgatók saját maguk rendelkeznek, a résztvevő három egyetem bármelyikét választhatják. Ez a kialakítás lehetővé teszi, hogy ténylegesen multikulturális környezetben, különböző oktatási módszerekkel tanuljanak vállalkozástant.

○ Summer Business Program: 4 hetes, oklevelet adó, nyári gyorstalpaló program, elsősorban nem üzleti végzettségüeknek.

\section{- Mester:}

○ MBA (Master of Business Administration): Hagyományos 2 éves MBA képzés. Elvégezhető még 3 éves levelező formában is.

○ IBEAR MBA (International Business Education and Research MBA): egy éves, gyorsított MBA program 8-10 éves munkatapasztalattal rendelkező, de még nem szeniori státuszú menedzsereknek.

○ EMBA (Executive MBA): Nagyobb tapasztalattal rendelkező szakembereknek, szenior menedzsereknek szánt 2 éves MBA program.

○ GEMBA (Global Executive MBA): 2 éves EMBA program, középpontban azonban a nemzetközi gyakorlatok állnak.

○ MAcc (Master of Accounting): Számviteli mesterképzés. 
○ MBT (Master of Business Taxation): Vállalati adózásra specializálódott képzés, amelynek céla olyan adózási szakértők kinevelése, akik potenciálisan magánvállalkozásoknál helyezkedhetnek majd el.

\section{- Igazgatói/Felsővezetői képzések:}

- Az egyetemen a Harvardhoz és a Babsonhoz hasonlóan elérhetőek néhány napos, egy-két hetes időtartamú, specializált programok.

○ Ezen felül ténylegesen személyre szabott képzéseket is biztosítanak (egyetemi szolgáltatás). Ennek során felmérik az ügyfél igényeit, és - folyamatos együttmüködés mellett - szakértők bevonásával összeállítanak, majd „leszállítanak” (előadás, tárgyalás, csapatmunka, esettanulmány, stb.) egy fejlesztési anyagot. A cél ez esetben a kérelmező vállalat müködésébe azonnal beépíthető gyakorlat megszerzése, megvalósítása.

○ Specializált tréningek: élelmiszeripari szereplőknek (FIM), veteránoknak (MBV: hadseregben megszerzett vezetői készségek mellé üzleti tudást is ad), orvosoknak (MMM: kórházak, klinikák vezetése)

○ Egyéb: Certificate in Technology Commercialization: A Summer Business Programhoz hasonló, de annál nagyobb horderejü. Elsősorban az orvostudomány, mérnökség természettudományok, területén tevékenykedő kutatók a célpont, de MB tanulmányaikat végző hallgatók is jelentkezhetnek rá. E képzés során a résztvevők megtanulják, milyen üzleti szempontokat érdemes figyelembe venni magas technológiai szektorba tartozó vállalkozások esetén. A képzés célja nem direktben „mindentudó high-tech vállalkozók” kinevelése, hanem kutatók üzleti rálátásának, vállalkozói hajlandóságának növelése. Ennek megfelelően ilyen területeket érintenek: technológia-kommercializáció, megvalósíthatóság, befektetések típusai, találmányból termékfejlesztés, stb.

\section{FONTOSABB KURZUSOK:}

- Alkalmazott Üzleti Statisztika (Applied Business Statistics)

- Adatelemzés és döntéshozás (Data Analysis for Decision Making)

- Megvalósíthatósági elemzés (Feasibility Analysis) 
- Vállalkozói beállítódás: bele kell ugrani! (The Entrepreneurial Mindset - Taking the Leap)

- IT Startupok indítása (The Digital Startup Launchpad)

- Vállalatok felvásárlása (Acquiring Your Own Business or Opportunity)

- Társadalmi célú vállalkozások (Social Entrepreneurship)

\section{STRATÉGIA:}

1. Social Entrepreneurship előmozdítása

Social Entrepreneurship: A vállalkozások egy olyan megközelítése, mely egy befektetés pénzbeli megtérülése helyett annak társadalmi megtérülésére (jólét) koncentrál. Ezzel a szemlélettel helyi és globális viszonylatban olyan nonprofit vagy forprofit vállalkozások jelennek meg, melyek az egészségügy, környezetvédelem, szegénység, oktatás területén igyekeznek pozitív hatást kifejteni. E vállalkozások modelljei némileg hasonlóak, de lényegükben eltérőek a hagyományos vállalkozásokétól. Az egyetem üzleti iskolájának egyik missziója az ilyen típusú vállalkozók és vállalkozások támogatása.

2. Networking szervezetek, fórumok

$\mathrm{Az}$ egyetem olyan szervezeteket müködtet $(\mathrm{EVMA}=$ Entrepreneur and Venture Management Association; e-Club=Entrepreneur $\mathrm{Club}$ ), melyek különféle szolgáltatásokat nyújtanak a hallgatóknak: fórumok, előadások, műhelymunkák, kerekasztal beszélgetések, befektetői hálózat (VC, üzleti angyalok), vállalkozói hálózat (tanácsadás, challengelés tapasztaltaktól).

3. Corporate connections - Kapcsolatalakítás vállalati szereplőkkel

Az egyetem lehetőséget biztosít külsős ipari, vállalati szereplőknek, hogy rész vegyenek a képzés formálásában, bekapcsolódhassanak bizonyos projektekbe, kapcsolatba kerülhessenek a hallgatókkal. Ez vendégelőadókon, tantervfejlesztésen, karriertanácsadáson, kutatási projekteken keresztül valósul meg. Cserébe az egyetem a Harvardhoz hasonlóan - toborzó szolgáltatásokat biztosít a cégek számára (pl.: megvehető a 2013-ban végzett USC-s hallgatók életrajzait összegyüjtő könyv). 
4. Kombinálható tanulmányi ösvények

Az egyetem nagy szabadságot biztosít a hallgatóknak, hogy tanulmányaikat igény szerint alakítsák. Ezáltal mindenki egyéni karrier aspirációi mentén tud haladni. Az Üzleti Iskola például 80 féle minor képzést ajánl. Ennek megfelelően - az egyetem más intézményeivel együttmüködve - üzleti majorral rendelkezőknek biotechnológiai, vegyészeti, információtechnológiai, mérnöki, illetve egyéb, bölcsészettudományi minorokat biztosít; míg másik esetben a természettudományos, mérnöki vagy bölcsészettudományi majorral rendelkező hallgatóknak lehetőségük van vállalkozástani, könyvelési, közgazdaságtani, stb. minorokat végezni.

\section{Syracuse University - Martin J. Whitman School of Management}

1870-ben alapított magán kutatóegyetem, székhelye Syracuseban, New York államban található. Az üzleti képzések oktatásáért a Martin J. Whitman Menedzseri Iskola felelős, mely 1919 óta müködik.A Princeton Review vállalkozói alapképzések oktatásában 3. helyre rangsorolja az Iskolát. A tantestület döntő többsége itt is vállalkozó.

\section{MÓDSZEREK:}

- Globális fókusz (,amerikai erasmus”: külföldi tanulmányok)

- Több szakmai gyakorlat is elvégezhető egy képzés alatt

- Entrepreneurship Field Experience: üzleti terv készítése, validálása

- „Karrierkutatás” (céglátogatások formájában: konkrétan milyen munkakörben lehet az egyes végzettségekkel elhelyezkedni)

- Meghívott felsővezetők előadásai (Google, IBM, Pepsi, Macy’s, stb.)

- Munkaerő toborzó szolgáltatás biztosítása vállalati ügyfeleknek (inkább állásbörzék, interjúk formájában)

\section{SZAKOK}

- Alap: A Babsonhoz hasonlóan sokféle, saját igény szerint bejárható ösvény van, emiatt nem olyan egyértelmü különálló szakokat definiálni. Példa majorokra: számvitel, vállalkozástan, pénzügy, menedzsment, marketing menedzsment, ingatlanbiznisz, kiskereskedelmi menedzsment, ellátásilánc-menedzsment. Az USC-hez hasonlóan itt is lehetséges kettős majorok, kettős programok végzése. 
- Mester:

○ MBA (Master of Business Administration): Hagyományos 2 éves MBA. A képzésen belül a következő szakosodások érhetők el: könyvelés, pénzügy, vállalkozástan, marketing menedzsment, ellátásilánc-menedzsment. Az oktatás fontos részét képezi a tapasztalat alapú tanulás (gyakorlati kurzusok, szakmai gyakorlatok, versenyek).

○ MSE (Master of Science in Entrepreneurship): 1 éves vállalkozói képzés, mely három fő karrierpályát támogat: új vállalkozás indítása; meglévő vállalkozás menedzselése; társadalmi célú vállalkozások indítása, működtetése.

\section{FONTOSABB KURZUSOK:}

- Felfedezni a vállalkozót: önmagunkban (Discovering the Entrepreneur Within)

- Születő vállalatok jogi kérdései: szellemi tulajdon, tőke, vezetés (Emerging Enterprise Law)

- Kisvállalkozások fejlesztése: gyakorlat (Emerging Enterprise Consulting): Hasonló a University of Michigan MAP kurzusához (valós üzleti problémák kollektív megoldása hallgatók által), de annál kisebb volumenü.

- Vita, mint gondolatébresztő (Dilemmas and Debates): Meghívott vállalkozók tartanak olyan interaktív foglalkozást, mely során érvelések hangzanak el pro- és kontra egy-egy több oldalról megközelíthető témában. A lényeg, hogy nincsen csak egyféle válasz (vállalkozói szemlélet erősítése).

- D’Aniello vállalkozói szakmai gyakorlat (D'Aniello Entrepreneurial Internship): Hasonlatos a University of Houston egyik Enrichment programjához: megpályázható szakmai gyakorlat, mely során a hallgató egy felsővezetővel dolgozhat együtt egy nagy növekedési potenciállal rendelkező, innovatív vállalkozásban.

- IT eszközök a döntéshozatalban (IT for Decision Support)

- A tôkepiac és intézményei (Financial Markets and Institutions)

- Ügyfélközpontú értékteremtés (Creating Customer Value)

- Vállalkozói gyakorlat: üzleti terv készítése, validálása (Entrepreneurship Field Experience) 


\section{STRATÉGIA:}

1. „Amerikai erasmus”

A nemzetközi gyakorlatban való megmerítkezést ez az egyetem hosszabb ideig tartó külföldi tanulmányokon keresztül éri el (1-2 szemeszter). Ennek megfelelően a hallgatók csaknem fele vesz részt például Olaszországba, Törökországba, az Egyesült Királyságba, Spanyolországba, Franciaországba, Lengyelországba, Kínába vagy éppen Chilébe szóló programokban. A hosszabb külföldi tanulmányokon kívül az egyetem biztosít rövidtávú, valamint nyári gyakorlati programokat is.

2. Entrepreneurship Field Experience

A kurzus során a leendő vállalkozóknak egy eredeti és megvalósítható üzleti ötlettel és az azt leíró üzleti tervvel kell előállniuk, melyet szemeszter végén egy befektetőknek tartott pitchben prezentálnak.

3. „Karrierkutatás”

Ez a módszer céglátogatások formájában ad betekintést a hallgatóknak arról, hogy az egyes végzettségekkel konkrétan milyen tevékenységet lehet végezni. Jóllehet felülről szerveződően az egyetem képzéskialakítása tükrözi egy adott ország munkaerő szükségleteit, ezt azonban nem árt a hallgatókkal is megismertetni. Tapasztalati úton tehát a hallgatók tisztább képet kapnak a végzettségüknek megfelelő karrierlehetőségeikről.

Ennek köszönhetően az egyetem - indirekt módon - nagyban hozzájárul a munkaerő kereslet és kínálat összeegyeztetéséhez. Magyarország esetében hasznos lenne ehhez hasonló tevékenységet már a felsőoktatási pályaválasztás előtt implementálni.

\section{Rice University - Jesse H. Jones Graduate School of Business}

1912-ben alapított magán kutatóegyetem, székhelye Houstonban, Texas államban található. Az üzleti képzések oktatásáért a Jesse H. Jones Üzleti Iskola felelős, mely 1974 óta működik.

Rangsorolását tekintve a Princeton Review vállalkozói mesterképzések oktatásában 4. helyre sorolja a University of Michigan, a Babson College, és a Harvard után. A Princeton Review alapján a tantestület döntő többségét vállalkozók alkotják, de honlapjuk szerint inkább 
magasan kvalifikált akadémiai oktatóikkal büszkélkednek. Az egyetem emellett kiemelkedik még nanotechnológiában, ürkutatásban, biotechnológiában és információtechnológiában is.

\section{MÓDSZEREK:}

- Kis csoportos oktatás (átlagosan minden 9 hallgatóra jut 1 oktató)

- Szimulációs gyakorlatok: üzleti érdekek ütközése, ennek „feloldása”

- Action Learning Project: 13 hetes gyakorlati kurzus, MAP-hoz hasonló

- Specializált képzések, kettős diplomák (üzlet-tudomány összeházasítása)

- Business Bridge Program: nyári gyakorlat, nem üzleti végzettségúeknek

\section{SZAKOK:}

\section{- Mester:}

○ MBA (Master of Business Administration): 2 éves MBA képzés. Az első évben a képzés magját alkotó kurzusok (Action Learning Project tavaszi szemeszterben) kerülnek átadásra, míg a második évről teljes egészében a hallgató rendelkezhet (szabadon választható kurzusok). A következő szakirányok érhetők el a programon belül: könyvelés, vállalkozástan, pénzügy, egészségügy, információtechnológia, nemzetközi üzlet, marketing, operatív müködés, szervezeti magatartás, stratégia.

○ EMBA (Executive MBA): Nagyobb (átlag 14 éves) tapasztalattal rendelkező vezetőknek szánt 2 éves levelező MBA program. A képzés során kiemelt szerepet kapnak a nemzetközi tanulmányutak, networking lehetőségek (üzleti kapcsolatok kialakítása). Az erős akadémiai oktatás mellett a résztvevők teljesítenek egy „sarokkő projektet” (Community Capstone Project) is. Ez talán a Harvard Case Methodjához hasonlít leginkább. Csoportos brainstorming, komolyabb kihívást jelentö üzleti problémákkal kapcsolatban.

○ MBA for Professionals: 2 éves levező MBA program. A képzés célja, hogy olyan gyakorlati oktatást adjon már dolgozó egyéneknek, melyet könnyen átültethetnek munkájukba, ezáltal növelve versenyképességüket, karrier lehetőségeiket. Ennek megfelelően inkább szektorspecifikus szakosodásokat biztosítanak: (pl.: ingatlan, egészségügy, energiaszektor, pénzügy). 
○ REEP (Rice University Education Entrepreneurship Program): Speciális 2 éves levező MBA program, kifejezetten általános- és középiskolai (K-12) tanárok, igazgatók üzleti aspirációinak kielégítésére. Fókuszban az oktatás.

\section{KETTŐS DIPLOMA PROGRAMOK:}

Olyan programok, mely során a hallgatók interdiszciplináris jelleggel két Iskolától két képesítést szereznek. Ez képessé teszi öket, hogy üzleti törekvéseiket az általuk választott tudományterületen belül valósítsák meg.

- MBA/ME (Master of Business Administration/Master of Engineering): biomérnöki, vegyészmérnöki, környezetmérnöki, anyagmérnöki, gépészmérnöki, építőmérnöki specializációk

- MBA/MD (Master of Business Administration/Doctor of Medicine)_ Pl.: $\quad$ orvosi iskolák, kórházak, klinikák, gondozók vezetői

- MBA/MS (Master of Business Administration/Master of Science) Pl.: környezettudományi, geológiai, fizikai területek

\section{- Igazgatói/Felsővezetői képzések:}

○ Az egyetemen a Harvardhoz, a Babsonhoz és az USC-hez hasonlóan elérhetőek néhány napos, egy-két hetes időtartamú specializált programok.

○ Az USC mintájára a Rice is ajánl vállalati igényekre szabott képzéseket. A folyamat az USC módszerével szinte teljesen megegyező, annyi különbséggel, hogy a Rice egyetem a program zárásával elvégez még egy minőségbiztosítási felmérést is, aminek keretében lemérik, hogy az oktatás mekkora hozzáadott értéket jelentett a vállalatnak. Ezen felül az éppen nem érintett, de potenciálisan lényeges fejlesztési lehetőségekről is informálják az ügyfelet.

\section{- Egyéb:}

○ Certificate Programs: Szintén az USC példáján a Rice is kínál rövid (egy-két hetes), oklevelet adó üzleti képzéseket. Ezek Pénzügy és könyvelés, Egészségügy, Ügyfélközpontú stratégia és Vezetés témakörökben érhetők el. A célcsoport itt is a nem üzleti végzettségűek köre.

○ Executive Development Programs: Menedzseri pozícióban lévő, üzleti háttérrel rendelkező egyénekre szabott rövid (két hetes) programok. Elérhetők egy $H R$ és 
egy általános fejlesztés specializációban. A programok célja a résztvevők karrierlehetőségeinek bővítése.

\section{FONTOSABB KURZUSOK:}

- Költség menedzsment (Cost Management)

- Változtatások implementálása (Leading Change)

- A magán és állami szektor kapcsolata (Business-Government Relations)

- Stratégiák tervezése és kivitelezése (Strategy Formulation and Implementation)

- Action Learning Project: gyakorlati kurzus (University of Michigan: MAP gyakorlatához, ill. Syracuse University: Emerging Enterprise Consulting kurzusához hasonló)

- Gazdasági érdekütköztetés (International Energy Simulation): két napos szimuláció, ahol a hallgatóknak egy képzeletbeli - de realitással bíró - érdekütközési problémát kell megoldani. Például egy fejlődő országban olajat találtak, amire igényt tart egy tőzsdén jegyzett olajipari vállalat (jelentős érdek kötődik hozzá). Milyen konfliktusok alakulnak ki, ha ipari versenytársak, környezetvédelmi és emberjogi szervezetek, állami intézmények, média és egyéb magánjellegű érdekek adódnak? Hogyan lehet ezeket a konfliktusokat megoldani?

- Energiaátállás kivitelezése (Managing Energy Transitions): szerepe, mint versenyelőny

- Vállalkozás a biotechnológia területén (Entrepreneurship in Biotechnology)

- Az alapítók és a kockázati tőke szerepe high-tech startupoknál (Roles of Founders \& Venture Capital in High-Tech Startups)

\section{STRATÉGIA:}

1. Kis csoportos osztályok

Intenzív; hallgató központú oktatást tesz lehetővé.

2. Action Learning Project

A University of Michigan MAP (Multidisciplinary Action Projects) kurzusához hasonló, 13 hetes csapatmunka. Ennek megfelelően külső magánvállalkozások üzletfejlesztési, probléma megoldási, konzultációs célzattal részvételi szándékot 
nyújtanak be az egyetemhez. Az Iskola MBA hallgatói csoportokban dolgoznak az egyes eseteken, akadémiai oktatók által vezetve, szorosan együttmüködve a céges kapcsolattartókkal is. Az Action Learning Project végére a hallgatók gyakorlatot szereznek, a résztvevő cégek pedig egy neves üzleti egyetem konzultációs szolgálatával lesznek többek, versenyképesebbek.

3. Specializált képzések

A metodika érdekessége, hogy nem tisztán csak üzleti specializációkra fektet hangsúlyt (REEP), hanem interdiszciplináris módon - kettős diplomák révén lehetőséget ad a tudományos szakmai önmegvalósításra egy magasabb - vállalati szinten. E stratégia kisebb formában (Business Bridge: 3 hetes gyorstalpaló üzleti képzés, nem üzleti végzettségüeknek) is megjelenik az egyetem tevékenységi körében.

\section{MIT Sloan - School of Management}

1914-ben alapított magán üzleti iskola. Az MIT (Massachusetts Institute of Technology) tagintézménye. Székhelye Cambridge-ben, Massachusetts államban, az Egyesült Államokban található. Az MBA50.com Premiership 2013 összesített amerikai ranglistáján 6. helyet ért el. Ezt felbontva: 4. helyezést szerzett a U.S. News \& World, 5. helyet a Financial Times, 9. helyet a Bloomberg Businessweek és a The Economist, valamint 12. helyet a Forbes listáján.

\section{MÓDSZEREK:}

- Központban a vállalkozás! - egyetemi kezdeményezések

- Egyetemi - Ipari interfész összeolvasztása

- Sokoldalú képességfejlesztés (hard/soft skills, gyakorlati megmerítkezések, aktív kikapcsolódás)

\section{SZAKOK}

- Mesterfok:

○ MBA: 2 éves MBA képzés. Az első szemeszter alapozó kurzusokról szól. Ezt követően lehetséges szakosodni (Enterprise Management; Finance; Entrepreneurship and Innovation). A tapasztalati tanulás intraszemeszter SIP- 
eken ${ }^{20}$ keresztül valósul meg, a gyakorlati megmerítkezés Action Learning Lab-ek segítségével történik. Ezeket egészítik ki a felfrissülést, pihenést szolgáló IAP (Independent Activities Period) időszakok.

○ Egyéb mesterképzések:

○ Leaders for Global Operations (2 éves mérnök-menedzser)

○ Master of Finance (1 éves pénzügyi)

○ MS in Management Studies (1 éves menedzsment)

○ System Design and Management (1 éves, mid-career mérnök-menedzser képzés)

○ Executive MBA (EMBA): 20 hónapos levelező képzés. Az egyes modulok fenntarthatóság, innováció, globális piacok és stratégia, komplex vállalatok vezetése témák köré csoportosulnak.

○ MIT Sloan Fellows Program in Innovation and Global Leadership: Egy éves nappali EMBA képzés (a munka eddig szünetel). A tempót jól jellemzi egy elhíresült hallgatói mondás: "drink-from-the-fire hose”. Végezni lehet diplomamunka megírásával (ez esetben az oklevél MS in the Management of Science), valamint hagyományosan is (MBA).

- Igazgatói/Felsővezetői képzések: A többi egyetemhez hasonlóan itt is megtalálhatók a nyílt és személyre szabott programok.

- Ezen felül szerezhetők felsővezetői oklevelek (MIT Sloan Executive Certificate) is. Ez voltaképpen a nyílt képzésekre kialakított „hüségprogram”. (Négy éven belül, 25 napnyi nyíltprogramon való részvétellel a következő oklevelek szerezhetők: Management and Leadership, Strategy and Innovation, Technology, Operations, and Value Chain Management).

FONTOSABB KURZUSOK:

- Mikroökonómia a menedzseri döntéshozásban (Economic Analysis for Business Decisions)

\footnotetext{
${ }^{20}$ SIP (Sloan Innovation Period): szimulációk, vezetők tartotta előadások, készségfejlesztő műhelymunkák, önértékelő és reflexiós gyakorlatok.
} 
- Induló vállalkozások felfuttatása (Designing and Leading the Entrepreneurial Organization)

- Változtatások tervezése és kivitelezése (Planning and Managing Change)

- Stratégiai döntéshozatal az orvosi biotechnológia területén (Strategic Decision Making in the Biomedical Business)

- Innovációmenedzsment: születő trendek (Managing Innovation: Emerging Trends)

- Hogyan hozzunk létre áttörő terméket, szolgáltatást? (How to Develop "Breakthrough" Products and Services)

- Vállalkozói tájkép az USA-n kívül (Entrepreneurship Without Borders)

- Innovatív területek vállalkozói: Információ- és kommunikációtechnológia, Energiaszektor, Biotechnológia (Entrepreneurs in Innovation: Information Technology, Energy, Biotechnology and Communications)

- „Megbontó” technológiák: ragadozó, vagy zsákmány? (Disruptive Technologies: Predator or Prey?)

- Innovációs versenyelőny (Innovation-driven Advantage)

\section{StratéGia}

1. Extrém kompetitív szelekció

Az egyetem legnagyobb erőssége a kiválóság. Ennek megfelelően csak a legkitűnőbb képességekkel rendelkező hallgatók kerülhetnek be a programokba. Ezt támasztja alá, hogy a 2013-2014-es évben a 4529 MBA-re pályázó hallgató közül csak 406-ot vettek fel. Ezek az arányok PhD programok esetében még élesebbek: 639 jelentkezőből 17 került be ${ }^{21}$.

2. Egyetemi kezdeményezések: toljuk a vállalkozói törekvéseket!

Az egyetem a lehető legkülönfélébb eszközökkel igyekszik elősegíteni a vállalkozói aspirációk megvalósulását.

- Tudást biztosít:

- LearningEdge (ingyenesen hozzáférhető menedzsment anyagok oktatók és hallgatók részére)

\footnotetext{
${ }^{21} \mathrm{http}: / /$ mitsloan.mit.edu/about/facts-and-figures.php
} 
○ MIT OpenCourseWare (ingyenesen hozzáférhetö oktatási anyagok: 2150 MIT-s kurzus)

- Támogatást biztosít: Organizations $(9$ egyetemi szervezet a vállalkozásfejlesztés jegyében -> pénzbeli, jogi, networking, soft készségeket fejlesztö, mentoráló támogatás)

- Közösséget biztosít: Student Clubs (20 hallgatói klub és kezdeményezés, kizárólag vállalkozói fókusszal!)

3. Egyetemi - Ipari interfész összeolvasztása

Mindkét fél részére - a leghatékonyabb együttműködését segítendő - az egyetem olyan központot müködtet, mely átmenet nélküli (seamless) kapcsolatot jelent az akadémiai kutatás és ipari alkalmazás között. Ez a központ (MIT Center for Digital Business) kifejezetten információtechnológiai specializációjú, de a modell járható útnak tünik egyéb iparágak tekintetében is.

4. Innovation Teams

Olyan gyakorlati kurzus, mely során egy, az egyetemről kijövő kutatási eredmény kommercializálását kell kidolgozni. A csapatmunka kimenetele: IP stratégia, versenytárselemzés, piackutatás, üzleti modell, piaci bevezetési módszer, értékesítési technika.

Az MIT Sloan sokoldalú képességfejlesztést biztosít. Az MBA programban a következők szerint történik képességfejlesztés:

- Hard skills (Általános - Alapozó kurzusok, Speciális- Szakirányú kurzusok, Alapozó, valamint szakirányos (Enterprise Management; Entrepreneurship and Innovation; Finance) tananyag átadása kurzusok formájában).

- Soft skills: SIP (Sloan Innovation Period), amely keretein belül üzleti szimulációk, vezetők által tartott előadások, készségfejlesztő mühelymunkák, önértékelő és reflexiós gyakorlatok találhatók meg

- Gyakorlati megmerítkezés: Action Learning Labs, ahol Kisebb elméleti felkészítő után a hallgatók szakmai gyakorlat jellegü projektekben vesznek részt. Ezeket a világon bárhol, bármilyen szervezetnél végezhetik (SMEs, MNCs, GOs, NGOs, Non-profits, stb.). 
- Aktív kikapcsolódás: IAP (Independent Activities Period), amely esetén négy hetes időszak alatt a hallgatók utazhatnak, kikapcsolódhatnak, vagy általánosan mủvelő előadásokat hallgatnak. A periódus célja: pihenés, networking, illetve egyéni érdeklődési körök bővítése.

5. Egyetemi kutatások, hasznosítható eredmények kommercializálása

Az egyetem indulása óta a 125000 MIT-s alumni (ebböl 22000 a Sloanról) összesen 25800 céget alapított, melyek 3,3 millió embert foglalkoztatnak ${ }^{22}$. Ha ők egy ország lennének, éves bevételük (2000 Mrd. USD) alapján, legrosszabb esetben is a 11. helyen végeznének a GDP világranglistán. Ezen kívül nem mellékesen 77 Nobel-díjast nevelt ki az intézmény.

E megállapítások együttesen egy olyan eredő tendenciára utalnak, miszerint a jövő vezetőinek fő szakmai erőssége nem annyira a specializáltság sokkal inkább az interdiszciplinaritás lesz.

Természetesen nem tủnnek el a koncentrált, egy adott szakmára felkészítő tréningek (ezek inkább alkalmazotti státuszú munkaerő képzésénél válnak be), de vezetői státuszú emberek esetében (lévén hogy erőforrás-allokálókról van szó), sokkal hatásosabbnak bizonyulnak az új típusú „eklektikus” képzések. Noha egyre több az átmenet (intrapreneur vállalkozók az egyik oldalról; proaktív, újító, vállalkozói attitüddel rendelkező alkalmazottak a másik oldalról), nagy adatsokaságot figyelembe véve, a súlypontok eloszlása még mindig tiszta képet rajzol ki: a vezetők többnyire sokoldalúak, az alkalmazottak jobbára specializáltak.

\section{Lehigh University - Baker Institute}

Az amerikai vezető egyetemek közül a Princeton Review 20. helyén álló Lehigh University-n működő Baker Institute vezetőjével, Todd A. Watkins-al sikerült írásban interjút készíteni. Todd elmondta, hogy a Lehigh University nagy lépéseket tett a vállalkozói környezet és a hallgatói startup folyamat kiépítésében egyetem szerte a Baker Institute for Entrepreneurship, Creativity and Innovation és a Lehigh vállalkozást elősegítő programjainak ösztönzésével.

2012-13-ban több mint 65 valódi startup (nem osztálytermi projektek) állt az indítás különböző fázisaiban az egyetemen. A Baker Institute programjai, workshopjai, kapcsolódó eseményei több mint 3500 részvevőt számláltak 2012-2013-ban. Két, egyetemisták által

\footnotetext{
${ }^{22}$ http://mitsloan.mit.edu/mba/mit-sloan-community/entrepreneurial-ecosystem/
} 
elindított startup elismerést vívott ki a közelmúltban: az EcoTech Marine bekerült az Inc500 leggyorsabban növekvő vállalatainak listájába az USA-ban; valamint a LifeServe Innovation társalapítói felkerültek a BusinessWeek Amerika Legjobb Fiatal Vállalkozóinak Top 25-ös listájára.

A Lehigh ezen folyamatában a hallgatói vállalkozókat segítő legfőbb partnerségek és erőforrások között szerepelnek a következők:

Ben Franklin Technology Partners of Eastern Pennsylvania (BFTP):

A Lehigh University teljes tulajdonú leányvállalata, amely a Lehigh kampuszán található, valamint a Ben Franklin TechVentures, high-tech inkubátor a korai szakaszban lévő vállalatok részére, szintén a kampuszon. A Lehigh legfejlődőbb hallgatói technológiai startup vállalatainak a TechVentures2 ad otthont, amely egy új szakmai inkubátor, melyet a BFTP nyitott meg 2011 őszén az első inkubátor közvetlen szomszédságában, és amely részt tud venni a nemzeti díjakat nyerő inkubátor valamennyi szakmai inkubációs tevékenységében és szolgáltatásában. A National Business Incubation Association (NBIA) a Ben Franklin TechVentures intézményét 2012-ben az Év Nemzeti Inkubátorává választotta. A Ben Franklin TechVentures a NBIA 2012-es Dinah Adkins Év Inkubátora, Technológiai Fókusz címét is elnyerte. Valójában 1983 óta a BFTP gazdaságfejlesztési modellként szolgál hasonló szervezetek számára országszerte. A BFTP 420 új vállalatot indított el, 1.017 új terméket és folyamatot fejlesztett ki, 14.922 új munkahelyet teremtett, és fenntartott 21.358 létező munkahelyet. A BFTP TechVentures egyedül több mint 408 millió dollár bruttó éves bevételt és 4.500 munkahelyet hozott létre.

A hallgatói startup folyamatához kapcsolódó partnerség a Southside Bethlehem Keystone Innovation Zone (KIZ), a Lehigh Valley Economic Development Corporation (LVEDC) irányításával.

A KIZ egy PPP együttmüködés, amely a Lehigh University körüli 4 négyzetmérföldes területen ösztönzi a vállalkozói lehetőségeket. Ez a környék adott korábban otthont a Bethlehem Steel számára, amely most a legnagyobb privát barnamező átépítés az USA-ban. A KIZ a közelmúltban lépett partnerségbe Bethlehem városával egy régi selyemfonoda felújítása és a Pi megnyitásának céljából, amely egy technológiai központ a kezdő technológiai vállalkozások elszállásolására csupán három tömbre a Lehigh kampusztól. A Pi- 
ben található vállalatok majdnem mindegyike a Lehigh-ból gyürüzött ki a hallgatók illetve az oktatói kar jóvoltából, beleértve a legnagyobb lakót, a Viddler-t, amely egy Lehigh hallgatói startup jelenleg több mint 20 foglalkoztatottal. A Lehigh személyzete vezetői szerepet tölt be a LVEDC és a KIZ testületeiben és számos bizottságában egyaránt. A projekt előmozdít egy olyan körforgást, melyben a vállalatok a Lehigh hallgatói startup akcelerátor programjai keretében létrejönnek, pénzügyi és mentori segítséget kapnak a KIZ-től és a BFTP TechVentures inkubátortól, majd a Pi új létesítményén belül fejlődnek, és végül, ahogy növekednek, átteszik székhelyüket a Lehigh Valley Ipari Parkokba vagy egyéb elérhető iparterületre a régióban. Mivel a Pi-ben túljelentkezés van indulása óta, Bethlehem városa egy hasonló létesítmény, a Tau létrehozását tervezi egy régi ipari Bethlehem Steel épületben, szintén csak pár tömbre a Lehigh-tól, 30 millió dolláros felújítási program kertében, 2014-es megnyitással.

\section{A hallgatói startup-ok további forrása a Manufacturers Resource Center(MRC)}

A Lehigh non-profit társulása, amely a kampuszon található, az MRC egy gazdaságfejlesztési program, mely specifikusan a gyártásra fókuszál, segítve a kis- és középméretủ gyártókat. A MRC partnerségben áll a Lehigh Iacocca Institute intézményével a Manufacturing Leadership Institute kialakításának és múködtetésének céljából, melyben a hallgatói és más startup-ok vehetnek részt. A MRC rendszeresen együtt dolgozik a Lehigh hallgatói startupokkal és más KIZ és BFTP vállalatokkal, valamint IPD hallgatói csapatokkal, összekapcsolva őket a MRC gyártói és erőforrási hálózatával. A MRC több mint 700 kis- és középméretű gyártó céggel működött együtt közép-kelet Pennsylvaniában. Az MRC mentoring és támogatói tevékenysége számos közelmúltbeli gyártáshoz kapcsolódó hallgatói startup kereskedelmi sikerének központi eleme, mint pl. EcoTech Marine és hField, valamint IPD hallgatói vállalatindítási projektek.

\section{Small Business Development Center (SBDC)}

Az SBCD tanácsadást, exporttámogatást és oktatási programokat biztosít kisvállalkozásukat elindítani vagy növelni kívánó vállalkozók számára. Évente több mint 1000 kisvállalkozást támogat. A Lehigh hallgatói startup-ok rendszeresen igénybe veszik a SBDC mentoring szolgáltatását, különösen az üzleti tervezés korai szakaszaiban. Továbbá, a SBDC oktatói kara kisvállalkozási és vállalkozástudományi kurzusokat oktat, többek között olyat is, amelynek keretében hallgatói csapatok dolgoznak valódi projekteken, mint pl. marketing 
tervek, számviteli rendszerek vagy web design, így segítve a SBDC kisvállalkozási ügyfeleit. A SBDC igazgatója a Baker Institute belső tanácsadó testületének is tagja.

\section{Integrated Product Development Program (IPD)}

Az IPD egy országosan elismert program, melyben különböző tudományágak, csakúgy mint üzleti, mérnöki, tervezési, művészeti és egyéb szakok, hallgatóiból álló csapatok dolgoznak együtt ügyfél vállalatokkal a kliens vállalatok által meghatározott, valós termékfejlesztésen, piacosításon és gyártásfejlesztési lehetőségeken. Az egyes csapatok együtt dolgoznak egy ipari mentorral, és olyan bizonyított folyamatot követnek, amely felismeri a problémát, üzleti lehetőséggé dolgozza ki, vad ötletekre ösztönöz innovatív megoldások létrehozásában, valamint biztosítja az erőforrásokat, a teljesen felszerelt workshopokat és a prototípus előállításának feltételeit az előállításhoz és a teszteléshez. Az IPD csapatok rendszeresen kapnak segítséget a MRC és SBDC központoktól, valamint és az IPD ügyfél vállalatok állandó jelleggel válnak KIZ és BFTP befektetésekké.

Összefoglalva, a Lehigh University, annak leányvállalatai, a BFTP, MRC és SBDC, valamint regionális partnerei a vállalkozásoktatás és startup létrehozásának új folyamatmodelljét alkották meg. Számos közelmúltbeli sikeres hallgatói start-up, pl. EcoTech Marine, GigMax, hField Technologies, Lehigh Valley Grand Prix, Viddler, tette székhelyét Bethlehem vagy Allentown szegényebb városrészeibe, több tíz millió dollárt generálva a gazdasági tevékenységben. Ezen startupok Lehigh programokból indultak és jelentős mértékben támogatták olyan partner szervezetek, mint a KIZ, BFTP, SBDC, MRC és LVEDC.

A LehighSiliconValley program 2012 januárjában indult és 2014 januárjában már harmadjára futott. LehighSiliconValley egyedi az egyetemi vállalkozási programok között. A Baker Institute 40-50 egyetemistát és 10-15 diplomást visz el a vállalkozás központjába, a Szilíciumvölgybe. Kihasználva a Lehigh 80 mérföldes távolságát New Yorktól, 2013-ban ezt kiegészítették a hivatalos LehighSiliconValley programot a „New York Experience” programmal, lehetőséget nyújtva a hallgatóknak, hogy két napig elmerüljenek New York vállalkozási színterében. Így a hallgatók össze tudták hasonlítani mindkét partvidék vállalkozói környezetét.

Az „élő esetek” felhasználása izgalmas tanulási környezetet eredményez, mely valódi vállalatokra, valódi szereplőkre és valós időben játszódó valódi helyzetekre koncentrál. az 
„élő eset” során az alapító ügyvezető igazgatók bemutatják vállalatukat a csoportnak, hasonlóan ahhoz, amikor befektetőknek prezentálják. Jellemzik a vállalkozást, megosztják az elképzeléseiket és előremutató stratégiákat közölnek. Előre kiosztanak anyagokat a cégről és az iparágról, hogy a hallgatók rákészüljenek. A hallgatók csapatokban együttmüködve elemzik és értékelik a látottakat és hallottakat; megvitatják a problémákat és megegyezésre jutnak; majd formálisan bemutatják megállapításaikat, következtetéseiket és javaslataikat közvetlenül az alapító ügyvezető igazgatónak.

A program népszerüségének köszönhetően 2013 áprilisában a keleti parton tovább terjeszkedtek egy új kísérleti programmal, a LehighBostonStartup programmal. A Szilíciumvölgyi program egyetemi közfigyelme elvezetett egy csoport elkötelezett végzett hallgatóhoz és más vállalkozókhoz, kockázati tőkésekhez és inkubátor szakemberekhez Boston területén, akik hajlandóak megosztani új vállalkozási tapasztalataikat és kapcsolataikat 40 hallgató számára gyakorlati, New England stílusú tapasztalatszerzés keretében. A LehighBostonStartup egy rövidebb, három napos terepgyakorlat volt, mely a LehighSiliconValley programhoz hasonlóan élő eset módszerre épült.

Todd A. Watkins szerint a vállalkozásoktatás (egyetemi vállalkozásösztönzés) sikere a következő stakeholdereken múlik:

- Alumni vállalkozók mint mentorok és potenciális befektetők, valamint az egyetemi müködés támogatói.

- Vállalkozók és üzleti vezetők helyi és regionális közössége.

- Regionális, nemzeti startup és üzleti támogatói szervezetek. 
2. sz. melléklet: Vizsgált nyugat-európai intézmények

\section{London Business School}

A Londoni Üzleti Iskola a University of London kollegiátusi kutatóegyetem egyik meglehetősen elitista - szakiskolája. 1964-ben alapították, székhelye Londonban, az Egyesült Királyságban van.

Nemcsak Európa, de világ szinten is elismert egyetemről van szó. Európai kategóriában a Financial Times és a Bloomberg Businessweek rangsorolásában is első helyet ért el. Ebből is látszik, hogy nevének igazi presztizse van (az itt végzettek nagyon magas fizetésre számíthatnak karrierjük során). A The Economist 3. és a Forbes 4. helye valószínűleg a magas tandíjból, illetve a túlzottan nagymértékü specializációból eredhet.

\section{MóDSZEREK:}

- Kapcsolatok ápolása nagyvállalati szereplőkkel

- Különböző nyári gyakorlatok biztosítása

- Kiterjedt nemzetközi csereprogramok

- Élvonalbeli akadémiai oktatók, vezető kutatás, szakértelem

- Networking: Interakciók erősítése hallgatói és alumni klubok, rendezvények által (konferenciák, műhelymunkák, fórumok, előadások).

- Csapatszellem erősítése: MBA-nél a hallgatók elsőéves értékelése 30\%-ban a csapat összteljesítményéből tevődik ki

- Egy hetes áthallgatások USA-ba, Dél-Afrikába, Indiába, Kínába vagy Törökországba (Global Business Experience)

\section{SzAKоK:}

- Mester:

○ MM (Masters in Management): 1 éves menedzsment mesterképzés.

○ MBA (Master of Business Administration): MBA képzés 15, 18 vagy 21 hónapos formában. Az egész (kb. 410 fős) szakot hozzávetőlegesen 75 fös 
csoportokra bontják (elöadások), aminek tagjai gyakorlati feladatoknál 6-7fös tanulócsoportokban dolgoznak együtt.

○ EMBA (Executive MBA): 20 hónapos, vezetőknek, menedzsereknek szóló levelező MBA képzés. Célja hogy az üzleti gyakorlatba gyorsan átültethető tudást adjon.

○ EMBA-Global Americas and Europe: 20 hónapos képzés a LBS és a Columbia Business School közös szervezésében. Tömbösített kurzusok Londonban és New Yorkban, választhatók Londonban, New Yorkban, Hong Kongban és Shanghaiban. Ez a képzés inkább a nyugati üzleti környezet, módszerek áttekintését nyújtja.

○ EMBA-Global Asia: 21 hónapos képzés a LBS, a Columbia Business School és a University of Hong Kong szervezésében. Tömbösített kurzusok mindhárom egyetemen, választhatók Londonban, New Yorkban, Hong Kongban és Shanghaiban hallgathatók. Itt a nyugatról inkább a keleti üzleti környezetre, módszerekre van helyezve a hangsúly.

○ Masters in Finance: Pénzügyi mesterképzés. Elérhető 18 és 22 hónapos (nappali és levelező) kivitelben.

○ Sloan Masters in Leadership and Strategy: 12 hónapos, vezetőknek, menedzsereknek szánt, vezetői készségeket fejlesztő képzés. Cél a karrierelőmenetel segítése (felsővezetésbe kerülés, szintentartás). Ilyen mesterképzés található még a Stanfordon és az MIT-n is.

\section{- Igazgatói/Felsővezetői képzések:}

○ Néhány napos, egy-két hetes időtartamú, specializált, intenzív programok.

- A fentieken kívül az amerikai USC-hez és Rice-hoz hasonlóan a LBS is ajánl egyéni, vállalati igényekre szabott programokat.

\section{FONTOSABB KURZUSOK:}

- Adatok, modellek, döntéshozás (Data, Models and Decisions)

- Müködésmenedzsment (Operations Management) 
- Magánszektor, kormányzat, társadalom (Business, Government and Society)

- Vállalkozási lehetőségek azonosítása (Discovering Entrepreneurial Opportunities)

- Helyi üzleti látogatások (London Business Experiences): Fél napos látogatások helyi vállalkozások körében, melyet prezentáció, elemzés zár.

- Üzleti lehetőségek élettudományi vállalkozásokban (Evaluation and Planning of Business Opportunities in Bioprocessing and Life Sciences)

- Posztkommunista országok a globalizációban (The Globalisation of Transition Economies)

- Vállalkozás feltörekvő gazdaságokban: BRICS, MIKT (Entrepreneurship in Emerging Markets)

- Vállalati átállások kezelése, kivitelezése (Managing Corporate Turnarounds)

- Vállalkozásindítás (New Venture Development): Üzleti lehetőség felismerése; meggyőző üzleti terv írása; hogyan bánjunk a befektetőkkel?

- Stratégiai innováció (Strategic Innovation): Miként újíthatják meg üzleti modelljüket régóta müködő vállalatok (established companies)?

- Társadalmi célú vállalkozások a XXI. században (The New Revolution: Social Entrepreneurship in the 21st Century): E kurzus felhívja a figyelmet egy olyan globális trendre, miszerint kizárólag állami tettlegességgel már nem lehet kielégíteni egy társadalom egészségügyi, oktatási, lakhatással kapcsolatos igényeit. E kihívásra korunk „társadalmi célú vállalkozóinak” (social entrepreneur) kell válaszolnia.

\section{STRATÉGIA:}

1. Kapcsolatok ápolása nagyvállalati szereplőkkel

Éves díj ellenében a nagyvállalati partnerek értékes, mindkét fél számára előnyös, szolgáltatásokat kapnak az egyetemtől:

- Hallgatók (munkaerő) rendelkezésre bocsátása

- Üzleti elemzések, módszerek, legfrissebb kutatás

- Globális kapcsolati háló: az egyetem konferenciáin, networking eseményein az előfizető cégek is kiállíthatnak (kihasználják a nagy reputáció oldalvízét)

- Kedvezmények az executive education programokra 
- Könyvtári hozzáférés (Európa egyik legteljeskörübb üzleti témájú gyüjteménye)

- Beszédek, előadások tartása (részt vehetnek a hallgatók szemléletformálásában)

2. Nyári gyakorlati lehetőségek

A hallgatók karrier aspirációik szerint 3 csoportba sorolható (alkalmazotti; konzultációs; vállalkozói) szakmai gyakorlatok közül választhatnak az MBA első- és másodéve között.

\section{- Nyári szakmai gyakorlat (Summer Internship)}

8-12 hetes, fizetett szakmai gyakorlat belföldön vagy külföldön. A résztvevők igény szerint maradhatnak saját iparágukban, de kipróbálhatják magukat más területen is.

\section{- Nyári konzultációs program (Summer Consulting Programme)}

A program során 6-8 hallgató alkotja a LBS konzultációs csapatát. Ennek során az iskola rendelkezésükre bocsát mindennemü forrást, amit használva magas szintü konzultációs szolgáltatásokat nyújtanak vállalati ügyfeleknek.

\section{- Nyári vállalkozói iskola (Entrepreneurship Summer School)}

E gyakorlat lehetőséget ad vállalkozó szellemü hallgatóknak, hogy teszteljék üzleti ötletüket. Ennek során piackutatást végeznek, majd mentorok, meghívott vállalkozók segítségével feltárják, hogy az ötletnek van-e valós relevanciája, érdemes-e a megvalósításába belekezdeni.

3. Kiterjedt nemzetközi csereprogramok

Erasmushoz hasonló, egy szemeszteres csereprogramok a résztvevő egyetemek között. A hallgatóknak lehetőségük van 32 intézet közül választani Európában, Ázsiában, Ausztráliában, Észak- és Dél-Amerikában. 


\section{INSEAD}

1957-ben alapított üzleti magániskola, székhelye eredetileg Fontainebleau-ben, Franciaországban található. 2000-ben nyitották meg szingapúri, 2007-ben abu dhabi (Egyesült Arab Emírségek) központját.

A The Economist kivételével (7. hely) minden szerkesztőség 2. helyre sorolta a LBS után. Ez a kiugró érték valószínüleg az egyetem elmarasztalt karrierszolgáltatásait tükrözi. (A Telegraph listája például 1. helyen szerepelteti, megelőzve ezzel a 2. helyen befutó LBS-t.)

\section{MóDSZEREK:}

- Interaktív, Harvardi típusú oktatás (lásd: Case Method)

- Multikulturális oktatói és hallgatói gárda (a világ 84 különböző országából):

- Campus Exchange (8 hetes áthallgatások az egyetem különböző kampuszain)

- Vállalkozói inspiráció (az itt végzettek 50\%-a vállalkozó lesz az élete folyamán)

\section{SZAKOK:}

- Mester:

○ MBA (Master of Business Administration): 10 hónapos MBA képzés. A rövid képzési időnek köszönhetően a hallgatók még jobban rá vannak szorítva az aktív órai munkára, valamint az egymással való kapcsolatépítésre.

○ GEMBA (Global Executive MBA): 14-17 hónapos levelező EMBA program, tapasztalattal rendelkező menedzsereknek. A leadott tananyagon kívül a képzés két sarkalatos pontja egy a - vezetői készségeket fejlesztő (Leadership Development Programme) - beágyazott program, valamint az otthon elkészítendő, írásos beadandók (Implementation Essays, Reflection Papers).

○ Master in Finance: 20 hónapos, levelező pénzügyi mesterképzés.

○ Executive Master in Consulting and Coaching for Change: 18 hónapos levelező képzés, mely pszichológiai megközelítésbe helyezi a vezetést. 
- Igazgatói/Felsővezetői képzések:

○ A LBS-hoz; USC-hez, Rice-hoz hasonlóan az INSEAD is ajánl sajátos vállalati igényekre szabott programokat.

○ Az egyetem ezen kívül sokféle; vezetőknek, menedzsereknek szóló specializált képzést kínál, melyek évente 2-5 alkalommal kerülnek megrendezésre. Időtartamuk 1-4 hét.

\section{FONTOSABB KURZUSOK:}

- Szervezeti magatartás (Organisational Behaviour): Az emberi viselkedés szerepe egy vállalaton belül, tárgyalás, vezetés, vállalati kultúra.

- Piacok és árazás (Prices and Markets)

- Bizonytalanság, adatelemzés, döntéshozatal (Uncertainty, Data and Judgement)

- A politika nemzeti és nemzetközi hatása a magánszektorra (International Political Analysis)

- Makroökonómia világgazdasági szinten (Macroeconomics in the Global Economy)

- Vállalatindítás a Szilícium-völgyben (Building Businesses in Silicon Valley): egy hetes tanulmányút az USA-ba

- Vállalkozás élesben (Entrepreneurship in Action): szimulációs gyakorlat, melynek célja, hogy a hallgatók szűk határidővel, nagy nyomás alatt dolgozzanak

- A hatékony tőkebevonás gyakorlata (Effective Fundraising for Entrepreneurs)

- Technológiai vállalkozások gyakorlata (Technology Venturing Practicum): Hogyan jut el egy innovatív koncepció a piaci bevetésig? - IP, licenszing, technológia transzfer, termék-életciklus; az innováció jellemzői felfutó-érett-hanyatló pályaszakaszokban, stb.

- Az első 100 nap (Your First Hundred Days): vállalati valóságshow

- Kék Óceán Stratégia (Blue Ocean Strategy): Több hús van a piacon, mint amennyin a versenytársak marakodnak. Hinni kell benne, meg kell találni, meg kell teremteni!

- A társadalmi felelősségvállalás a stratégia lényegi eleme (Strategic Corporate Social Responsibility)

- Értékteremtés és „Blue Line” menedzsment (Value Creation and Blue Line Management): Kurzus a „Blue Line”, vagy értékközpontú, értékteremtő menedzsment elméletéről szól. Ellentétben az úgynevezett „Red Line” menedzsmenttel, ami a 
hangoztatott értékteremtés helyett, valójában értékfüggetlen indikátoroknak való megfelelésről szól.

\section{STRATÉGIA:}

1. Harvardi típusú oktatás

A Harvard 'Case Method' kurzusához hasonlóan itt is megjelenik a szerepjáték, valamint az előadás interaktív levezénylése (az oktató részben, mint „,provokatív müsorvezető" funkcionál).

2. Nemzetközi csapatmunka

A tanulmányi felelősök a képzés kezdetén irányítottan állítják össze az együtt dolgozó tanulói csoportokat. A cél minden esetben a diverzitás. Nemcsak nemzetiségben, de korban, nemben; oktatási háttér, szakmai tapasztalat, ipari érdekeltség terén egyaránt. Ez a megközelítés szintén hasonlít a Harvard-féle sokoldalú problémaelemzéséhez.

Ezen túlmenően pedig felbecsülhetetlen értékeket ad: tanulási lehetőséget egymástól és tapasztalatot a nemzetközi csapatmunkáról.

3. Campus Exchange

Az INSEAD-nál az egyetemi tanév 5 darab, egyenként 8 hetes periódusra van osztva. E periódusokból a hallgatók az első kettőt az induló kampuszukon töltik, a maradék hármat pedig igény szerint máshol (akár a két nem választott INSEAD kampuszon, vagy partneri viszony keretében az USA, vagy Kína más üzleti egyetemein).

E technika hasonlatos az USC WBB (World Bachelor in Business) programjához (az alapképzés minden évét más országban, más egyetemen töltik). Az előnyük ezzel szemben az, hogy míg a legtöbb egyetem túl rövid (1-2 hetes), az USC talán túl hosszú (1 éves), addig az INSEAD optimális időtartamú (8 hetes) csereprogramokat biztosít. Ez az elosztás már kellő időt ad a hallgatónak a nemzetközi megmerítkezésben, ugyanakkor nem löki hosszasan egy esetleges kényszerpályára. A kötelező kurzusok mindegyike, a szabadon választhatók többsége mindhárom kampuszon hallgatható. 
4. Nagyon jó egyetemi marketing és üzletfejlesztés!

Az INSEAD kivételesen figyelemre méltó módon fejlesztette ki képzését és épített brandet magának.

Valószínüleg igen mélyreható kutatás előzte meg, és jellemzi mind a mai napig tantervi, didaktikai, szervezeti felépítését. Nagyon sok Harvardos eszközt használ, miközben nem nehezült el, hanem megörizte fiatalos dinamizmusát. Ez egyfajta Babsonos lendületet és potenciált kölcsönöz neki. Emellett kiemelt figyelmet fordítanak egy pezsgő, de ugyanakkor dolgos hallgatói légkörre ('Work hard, play hard, go far!'), ami leginkább a University of Houstonra és a University of Southern California-ra emlékeztet.

\section{IMD}

Az IMD (International Institute for Management Development) két üzleti iskola (IMI+IMEDE) egyesülésével jött létre 1990-ben. Székhelye Lausanne-ban, Svájcban található.

Ez az egyetem végzett a Forbes ranglistájának 1. helyén. Ez valószínűleg az MBA képzés rövidségének (11 hónap: mellesleg ez a leghosszabb képzésük), illetve a végzés utáni nagyon magas várható fizetéseknek köszönhető.

\section{MóDSZEREK:}

- Az intézet sokkal inkább nemzetközi business hub, mint egyetemi oktatási intézmény.

- Globálisan pozícionáltak (nincs kitüntetett ország, a cél nemzetközi üzleti vezetők képzése).

- Nincs hierarchia, nehézkes egyetemi gépezet.

- Közvetlen, személyes képzések (résztvevők-oktatók aránya 2:1).

- Interaktív, online támogató felület, hogy a résztevők könnyedén eligazodhassanak a programok dzsungelében, és a szükségleteiknek leginkább megfelelö(ke)t választhassák ki. E képzések éves naptári bontásban is hozzáférhetők. 


\section{SZAKOK}

- Mester:

○ MBA (Master of Business Administration): 11 hónapos menedzsment mesterképzés. Nagy hangsúlyt fektetnek a vezetői és személyes képességek fejlesztésére, valamint különféle projekteken keresztül lehetőséget nyújtanakgyakorlati tapasztalatszerzésre.

○ EMBA (Executive MBA): 15 hónapos, vezetőknek, menedzsereknek szóló levelező MBA képzés. Célja hogy valós, üzleti gyakorlatba hatékonyan átültethető tudást adjon (az átültetést ténylegesen végigasszisztálják). A programnak van egy alapozó és egy erre épülő megvalósító szakasza. Újítás, hogy a szakaszok egyes moduljai nagyrészt távoktatásban (e-learning) is végezhetők.

\section{- Igazgatói/Felsővezetői képzések:}

○ Az egyetem sokféle; vezetőknek, menedzsereknek szóló specializált programot kínál.

- Az amerikai mintától kissé eltérőn az európai gyakorlat, iparági specializációk (pl. Babson, Harvard: BioPharma; IT Leader Development Program; Emerging Issues in Health Care; IP Strategy; stb.) helyett inkább vezetői készségek fejlesztésére helyezi a hangsúlyt (pl. LBS, INSEAD, IMD: Negotiating and Influencing for Senior Managers; Leading the Effective Sales Force; Strategic Finance; Program for Executive Development). E képzések évente több alkalommal kerülnek megrendezésre. Időtartamuk néhány naptól néhány hétig terjed.

- A korábban említett egyetemekhez (LBS, INSEAD, USC, Rice) hasonlóan az IMD is kínál sajátos, vállalati igényeket kielégítő programokat.

\section{FONTOSABB KURZUSOK:}

- B2B Marketing

- A vállalkozás története: mit tanultunk a múltból? (Business History: Lesson from the Past)

- IT Stratégia (IT strategy)

- Partnering, mint stratégiai versenyelőny (Leveraging Partnerships for Strategic Advantage) 
- A nemzetközi növekedés kezelése pénzügyi, stratégiai szempontból (Managing International Growth: A Strategic Finance View)

- A közösségi média stratégiai alkalmazása (Social Media Strategy)

\section{STRATÉGIA:}

1. Vállalati szereplők bevonása

Az IMD szintén lehetőséget biztosít vállalati szereplőknek, hogy együttmüködjenek az egyetemmel, illetve éljenek annak szellemi tőkéjével. Ennek megfelelően a következő szolgáltatásokat biztosítják az ügyfeleknek:

- Toborzás (a cégek MBA hallgatókból válogathatnak)

- Startup projektek: a hallgatók besegítenek technológiai startupok felpörgetésébe (ez egyúttal üzleti gyakorlati lehetőség is számukra)

- Konzultációs szolgáltatás (érettebb vállalkozások üzleti kihívásaira egy erre kinevezett hallgatói csapat végez elemzést, majd kínál megoldást)

2. Az intézet sokkal inkább nemzetközi business hub, mint egyetemi oktatási intézmény

Ezt nevezhetjük stratégiának, de sokkal inkább ügyes pozícionálásról van szó. Ebben az értelemben az IMD, mint általános értelemben vett egyetem kissé túlértékelt; azonban mint üzleti szakképzéseket, szolgáltatásokat adó intézmény, igenis elismerésre méltó.

\section{IESE Business School}

Az IESE Üzleti Iskola a Navarrai Egyetemhez tartozik, 1958-ban kezdte meg működését. Székhelye eredetileg Barcelonában volt, de kampuszai megtalálhatók már Madridban, New Yorkban, Münchenben és Sao Pauloban is.

1964-ben a Harvard támogatásával ez az Iskola indított el elsőként két éves MBA képzést Európában. 2010-es New York-i kampuszuk megnyitása pedig Európa első olyan üzleti iskolájává tette őket, akik állandó központot hozott létre az USA-ban.

Az Iskola a The Economist rangsorolásában 1. helyet ért el az európai egyetemek között. Ez egyrészt a végzett hallgatók éves kereseti növekményének, másrészt a végzetteket foglalkoztató cégek nagy diverzitásának köszönhető. Az IESE-n végzettek 30\%-a fog vállalkozásba élete folyamán. 


\section{MóDSZEREK:}

- Interaktív oktatás (egy az egyben átvett Case Method)

- Globális szemlélet (interkulturalitás, nemzetköziesedés)

- Aktív vállalkozásfejlesztés (EIC - Entrepreneurship an Innovation Center)

- Pénzbeli támogatás StartUp-oknak: FINAVES, Business Angel Network

- 9 hetes nyári szakmai gyakorlat

- Kampuszközi áthallgatások

- Nemzetközi csereprogramok

- Mind az oktatásban, mind az üzletben: Központban az emberi értékek

- Könnyedén megközelíthető, nyitott oktatók, egyetemi személyzet (,open-door policy”)

- Saját üzleti portál és elektronikus folyóirat müködtetése: IESE Insight

\section{SzAKOK}

- Mester:

○ MBA (Master of Business Administration): 19 hónapos MBA képzés. Az első év az alapozó kurzusokról szól; ezt követi egy nyári szakmai gyakorlat; majd másodévben a hallgatóknak el kell készíteni saját üzleti tervüket, melyet kiválasztás esetén még befektetők elé is vihetnek.

○ EMBA (Executive MBA): 5 évnél több szakmai tapasztalattal rendelkező, végzett hallgatóknak szóló, 19 hónapos, levelező EMBA program. Az első alapozó év után - másodévben - a menedzsment készségek és a vállalati stratégia fejlesztésére tevődik a hangsúly.

○ GEMBA (Global Executive MBA): 16 hónapos, levelező EMBA program, ahol kiemelt szerepet kapnak a nemzetközi piacok, és globális gyakorlat. A képzés 9 modulból épül fel, melyek mindegyike három részből áll: egy alapozó, előkészítő; egy elméleti oktatásból és csoportfeladatokból álló; valamint egy önálló, otthoni munkára épülő, a munkahelyi gyakorlatba történő átültetést célzó szakaszból.

\section{- Igazgatói/Felsővezetői képzések:}


○ Az egyetem a legkülönfélébb; vezetőknek, menedzsereknek szóló programokat kínálja.

○ Találhatók közöttük kifejezetten vezetői, menedzseri képességeket fejlesztők; iparág- specifikusak; az egyes vállalati müködésekre specializálódók; illetve globális trendeket feltárók is. Ezen kívül biztosítanak teljesen személyre szabott programokat; és szerveznek iparág-specifikus konferenciákat is. E képzések időtartama változatos: néhány héttől, néhány napig terjedők is megtalálhatók a kínálatban.

- Egyéb: Érdekességként meg kell említeni, hogy az IESE olyan egyetem, ahol a külföldi üzleti iskolák oktatóit is oktatják (International Faculty Program).

\section{FONTOSABB KURZUSOK:}

- Üzleti problémák elemzése (Analysis of Business Problems)

- Humánmenedzsment (Managing People in Organizations)

- Kvantitatív elemző módszerek a menedzsment szolgálatában (Quantitative Methods for Management)

- Vállalatvezetés: rendszerek, értékek, etika (Leading Organizations: Systems, Values \& Ethics)

- Az információ- és kommunikációtechnológia beszivárgása szervezetekbe, piacokba (Transforming Organizations and Markets with ICTs)

- Hogyan hozhatjuk elő a bennünk rejlő kreativitást? (Creativity for Managers)

- Tárgyalástechnika (Negotiation)

- Különböző kultúrájú munkaerő menedzselése (Cross Cultural Management)

\section{STRATÉGIA:}

1. Emberközpontúság az oktatásban és vállalkozásban

Az Iskola olyan, szofisztikált menedzsment technikákat tanít, melyek hatékony interakciós (szűkebb értelemben: kommunikációs) képességgel ruházzák fel a vezetőket, hogy azok a lehető legtöbbet hozzák ki alkalmazottaikból, ügyfeleikből, beszállítóikból, valamint a pénzügyi és állami szereplőkből.

2. Segítségnyújtás más országok vállalkozásoktatási intézményeinek 
Az egyetem számos alakalommal nyújtott már segítséget egyéb külföldi egyetemeknek, hogy vállalkozásoktatási programjukat felfejlesszék.

3. Aktív vállalkozásfejlesztés: partnering rendezvények, befektetői hálózat biztosítása

Az EIC (Entrepreneurship and Innovation Center) célja, hogy felkutatassa a felek közötti különféle kooperációs lehetőségeket, valamint teret biztosítson megvalósulásukhoz: Partnering eseményeket szerveznek, ahol befektetők, vállalkozók, kutatók, az egyetemi tantestület léphet kapcsolatba.

Másik oldalról létrehoztak két befektetői szervezetet (FINAVES: Financing New Ventures; és Business Angel Network), melyek aktívan járulnak hozzá az egyetemről kikerülő projektek/kutatások üzleti megvalósításához (nagy növekedési potenciálú vállalkozások).

4. Public-Private Sector Research Center (PPSRC)

E központ egészen érdekes megközelítésbe helyezi az állami és magánszektor kapcsolatát:

Az egyetemen folyó kutatásokat, a magánszektorban bevált gyakorlatokat igyekeznek minél nagyobb mértékben átültetni az állami szektor müködésébe. Céljuk ezzel, hogy egy sokkal hatékonyabban - a magánszektor mintáján - müködő állami gépezetet alakítsanak ki.

5. Nemzetközi áthallgatások, csereprogramok, gyakorlatok

Az egyetem lehetőséget biztosít: néhány hetes áthallgatásokra különböző országbeli kampuszain; fél éves csereprogramokra 26 partnerintézménynél, a világ számos országába; valamint 8-11 hetes szakmai gyakorlatokra vállalati ügyfeleknél.

\section{IE Business School}

1973-ban alapított magán üzleti iskola. Székhelye Madridban, Spanyolországban található. Kiemelt figyelmet fordítanak az induló vállalkozások egyetemi oldalról történő támogatására. A rangsorolás tekintetében 3. helyet ért el a Bloomberg Businessweek, 4. helyet a Financial Times, 5. helyet a Forbes listáján. 


\section{MóDSZEREK:}

- Funkcionális területekre specializálódott, MBA-t kiegészítő programok.

- Innovatív tanrend: a hagyományos modulokat (core); rövid, alternatív (change) periódusokkal gazdagítják (kitekintés más iparágakra, meghívott előadók, műhelymunkák).

- Távoktatás erőteljes alkalmazása (főleg levelezőknél).

- Nemzetközi hallgatói környezet

\section{SZAKOK}

- Mester:

○ Masters in Management: 10 hónapos menedzsmentképzés. Hallgatók átlagos munkatapasztalata: 1 év.

○ International MBA: 13 hónapos, nappali MBA képzés. A hallgatók átlagos munkatapasztalata 5 év. A LBS-hoz hasonlóan az IE is biztosít egy képzés előtti „állapotfelmérést”, pótló kurzusokat. Ezt követően, még mindig az első periódus előtt a hallgatók részt vesznek egy önfejlesztő-csapatépítő programon, melynek célja a versenyszellem növelése, illetve együttmüködési készségeik fejlesztése. Ezután kezdődnek a fentebb már említett 3 hónapos hagyományos modulok (core), 1 hetes alternatív (change) periódusokkal elválasztva. Ennek az elrendezésnek az a célja, hogy a hagyományos „katedrális” oktatást kiegészítsék pihentetőbb, „epizód” jellegű tevékenységekkel (iparági kitekintés, esettanulmányok, mühelymunkák) A befejező (Elective period) szakaszban (utolsó 3 hónapos modul) a hallgatók önmaguk dönthetik el, mivel szeretnék kitölteni ezt az időszakot. Vehetnek fel szabadon választható kurzusokat; szakmai gyakorlatokon, nemzetközi csereprogramokon (az egyik legszélesebb paletta), konzultációs gyakorlaton vehetnek részt; társadalmi célú projektekben dolgozhatnak, illetve üzleti inkubációs praktikumot (Venture Lab) is teljesíthetnek.

○ Global MBA: 12-15 hónapos levelező GMBA. A képzés kevés személyes jelenlétet követel, főleg távoktatáson keresztül valósul meg. Az központi tananyag 
után a hallgatók a lentebb említett - MBA-t kiegészítő - funkcionális képzések valamelyikére szakosodhatnak.

○ EMBA (Executive MBA): 12-16 hónapos levelező EMBA. A résztvevők tízéves átlagos munkatapasztalattal rendelkeznek. A tananyag az MBA képzéshez hasonló, ám annál valamivel professzionálisabb. Tapasztaltabb menedzsereknek, vezetőknek szól. Szakosodás szintén a lentebb említésre kerülő funkcionális modulok irányába lehetséges.

○ GEMBA (Global Executive MBA): 13 hónapos levelező GEMBA. A résztvevők átlagos munkatapasztalata 14 év. A tananyag távoktatáson, illetve 1-2 hetes tömbösített üléseken kerül átadásra (alkalomról-alkalomra a világ más-más országaiban). A képzés négy fontos területre fektet hangsúlyt: MBA (biznisz szélesebb kontextusban); MGT (menedzsment, stratégia); Lead (vezetés); Endeavor (üzleti stratégiánk prezentálása egy tapasztalt vállalkozókból, szakértőkből álló testület előtt -> értékelés, potenciális fejlesztési lehetőség).

- IE Brown EMBA: 15 hónapos, az IE és a Brown University által közösen szervezett, levelező EMBA program. Ez a vezetőknek, menedzsereknek szóló képzés, a Brown által merít a társadalomtudományok, mérnöki tudományok és élettudományok területéröl is.

○ Egyéb pénzügyi mesterképzések.

- MBA-t kiegészítő, funkcionális képzések: 6 hónapos, modulokból álló programok. Választható területek: Vállalati pénzügyek, Marketing, Vállalkozástan, Információtechnológia, Egészségügy

- Igazgatói/Felsővezetői képzések: Az egyetem egyaránt biztosít nyílt, és személyre szabott programokat is. Ezek időtartama néhány naptól akár 3 hónapig is tarthat.

\section{FONTOSABB KURZUSOK:}

- Kommunikációs készségek (Communication Skills)

- Technológia és innováció menedzsment (Technology and Innovation Management)

- Vállalkozás és kockázati tőke (Entrepreneurship and Venture Capital) 
- Üzleti lehetőségek a megújuló energiaforrások területén (Renewable Energy Business)

- Társadalmi célú vállalkozások (Social Entrepreneurship)

- Pénzügy vállalkozóknak (Entrepreneurial Finance)

- Kreativitás és ötletgyártás (Creativity and Ideation)

- Vállalkozás a gyakorlatban (The Entrepreneurial experience. Do it yourself!): Hasonlatos a Babson féle cégépítős gyakorlathoz (Foundations of Management and Entrepreneurship).

- Befektetések értékelése (Investment Analysis)

\section{STRATÉGIA:}

1. Áttekinthető weboldal, programportfolió és képzésszerkezet

Bár apróságnak tűnhet, az egyetem vonzóvá tételét nagyban befolyásolja honlapjuk letisztult formája, logikus elrendezése. A személyes találkozásokon és látogatásokon kívül elvégre ez az első számú színtér, ahol az Iskoláról a leendő hallgatók véleményt alkotnak.

A helyes elrendezés azt eredményezi, hogy az egyes felhasználók a lehető leggyorsabban tudják megtalálni a számukra releváns információt. Az egyetem ezzel is sugall egyfajta szakértelmet, lényegre törő jellemvonást. Erre ellenpélda a University of Oxford honlapja.

2. Venture Lab

Hallgatók és alumnik vállalkozási törekvéseinek (kifejezetten nagy növekedési potenciállal rendelkező, innovatív ötlettel lehet nevezni) teret adó kezdeményezés. A folyamat két szakaszból épül fel. A hosszabb elökészítő (Venture Lab Accelerator) fázisban a résztvevők egy inkubációs procedúrán mennek keresztül. Ennek során egy 8 hónapon át tartó, 10 alkalmas oktatást is magában foglaló gyakorlati felkészítés történik. Minden projekthez (csapathoz) biztosítanak egy mentort (vállalkozó/befektető/üzletember), aki szektorspecifikus tapasztalatával segíti a leendő vállalkozókat. Ez a felkészítő szakasz egyben egy verseny és szelekció is a második fázisra: Venture Days (befektetői fórum). Itt a legjobb 5 projekt kerülhet bemutatásra 
helyi és nemzetközi befektetők előtt, ami jó eséllyel a vállalkozás tényleges elindulásához és felfuttatásához vezet.

3. MBA-t kiegészítő funkcionális modulok

Ezek az GMBA és EMBA programokat kiegészítő speciális modulok (Vállalati pénzügyek, Marketing, Vállalkozástan, Információtechnológia, Egészségügy) olyan 6 hónapos képzések, melyek voltaképpen szakirányokat jelképeznek, ugyanakkor külön képzésekként vannak feltüntetve. Ennek köszönhetően (moduláris jellegükből adódóan) esetlegesen hozzákapcsolhatók más végzettségekhez, így több „papírt” (szakirányú tudásról szóló bizonyítványt) tudnak nyújtani. Ez versenyelöny lehet a többi egyetemmel szemben.

\section{University of Cambridge Judge Business School}

1954-ben alapított, főként menedzsment képzéseket kínáló állami üzleti iskola. Szervezetileg a University of Cambridgehez tartozik, székhelye Cambridgeben található. Rangsorolásban 5. helyet ért el a Financial Times, 8. helyet a Forbes, és 9. helyet a The Economist listáján.

\section{MóDSZEREK:}

- Belső, egyetemi üzleti képzések kutatóknak, mérnököknek.

- MPhil üzleti programok, PhD-soknak, MSc-n végzetteknek.

- Belső, egyetemi üzleti képzések kutatóknak, mérnököknek,

- egyéb területek hallgatóinak.

- 'Up-to-date' kurzusok az üzleti világ legújabb trendjeiről, kihívásairól.

- Soft skill-ek fejlesztése

\section{SzAKOK:}

\section{- Mester:}

○ MBA: 12 hónapos nappali MBA képzés, 8 választható szakiránnyal (pl.: vállalkozástan, pénzügy, nemzetközi üzleti gyakorlat, stratégia és marketing, egészségügy, társadalmi innováció, energiaszektor és környezetvédelem, stb.). A központi tananyagon kívül a hallgatók saját igényeikre formálhatják programjukat. Ennek megfelelően tehát a szakirányok és szabadon választható kurzusok mellett több gyakorlati lehetőség közül is választhatnak (részvétel 
konzultációs tevékenységben, „capstone”projektben, változatos nyári programokban).Az MBA további erőssége a képzésbe integrált, vállalkozók által tartott előadások (ezek célja az inspiráció és a vezetői kvalitások felébresztése a hallgatókban)

○ Master of Finance: 12 hónapos pénzügyi mesterképzés.

○ Executive MBA (EMBA): Szenior szintű vezetőknek szóló, 20 hónapos levelező EMBA képzés. A program egyik érdekessége az International Business kurzus, mely egy tanulmányút keretében, céglátogatások formájában vizsgálja, hogy miért és hogyan léptek nemzetközi piacra az egyes szereplök?).

- Igazgatói/Felsővezetői képzések: Az egyetem egyéni (nyílt és személyre szabott programok) és céges szinten (vállalati igényekre szabott programok) biztosít képzéseket.

\section{- Egyéb:}

○ MPhil programok: 9-12 hónapos; oktatási szintjük alapján MSc és PhD Az egyetem, célcsoport szerint kétféle MPhil képzést különít el. Az első kategória olyan, nem üzleti MSc-n végzetteknek szól, akik szakterületükhöz kapcsolódó vállalkozást szeretnének indítani, vagy menedzseri/vezetői pozíciót szeretnének egy tudásintenzív vállalatnál betölteni (Professional Practice MPhils: Management; Technology Policy). A második kategória olyan, eredetileg is üzleti orientációjú hallgatóknak szól, akik akadémiai keretek között szeretnének kutatói pályát befutni az üzleti tudományok területén. Ennek megfelelően a $\mathrm{PhD}$ első évét képezi a szakirányú MPhil képzés, és ezt követően kezdődik el a tényleges doktori program (Research MPhils: Finance; Innovation, strategy and organisation; Management science and operations; Economics Research).

○ Postgraduate Diploma in Entrepreneurship: 12 hónapos, távoktatáson alapuló vállalkozói képzés, mely szaktudással és némi gyakorlattal ruházza fel a résztvevőket. Valójában a Professional Practice MPhil képzések alternatívája, kifejezetten vállalkozásindításra kihegyezve. A program a következő nagyobb területekre koncentrál: Entrepreneurial Awareness \& Skills; Opportunity 
Recognition \& Idea Evaluation; Preparing \& Implementing the Business Case; Managing the Early Stage Venture

○ Management of Technology \& Innovation (MoTI): Belső képzés egyetemi kutatóknak, mérnököknek. Segít nekik megszerezni a technológiaikommercializációhoz szükséges készségeket és tapasztalatot.

○ Management Studies Tripos: Szintén belső képzés olyan harmad- és negyedéves Cambridge-es hallgatóknak, akiknek végzésüket követően szakmájuk mellett valószínüsíthetően menedzseri feladatokat is el kell majd látniuk leendő munkaadójuknál. Kiegészítő jelleggel az ilyen irányú szaktudás megszerzését szolgálja ez a program.

\section{FONTOSABB KURZUSOK:}

- A menedzsment tudománya (Management Science)

- A menedzsment gyakorlata (Management Practice)

- Stratégiai Innovációmenedzsment (Managing Innovation Strategically)

- Vállalatvezetés és etika (Corporate Governance \& Ethics)

- Az ügyfelek viselkedése és magatartása (Consumer Behaviour)

- Hedge funds

- Gyógyszerek és biotechnológia (Pharmaceuticals \& Biotechnology)

- Technológiai cégek indítása (Entrepreneurship: How to Start a Technology Company)

- Modern üzleti stratégia (Advanced Strategy)

- Gyors vállalati reakció, nagyvállalati vállalkozástan, üzleti érzék (Fast Strategy, Intrapreneurship and Business Instinct)

- Filozófia az üzlet életben (Philosophy in Business)

\section{STRATÉGIA:}

1. Vállalkozói szellemiség terjesztése, kibontakoztatása (,Spreading the Spirit of Enterprise.”)

Az Üzleti Iskolának egy külön, erre a célra létrehozott központja (Centre for Entrepreneurial Learning) foglalkozik az egyénekben rejlő vállalkozó felébresztésével. 
E misszióval összhangban a központ különféle kurzusokat, képzéseket, konferenciákat, rendezvényeket szervez, hogy elösegítse e képességek kibontakoztatását. Ezek között szerepelnek hetente megrendezésre kerülő networking események; technológiai kutatásokból innovatív vállalkozások létrehozását célzó kezdeményezések; vállalkozói készségeket feltáró és fejlesztő képzések; valamint meghívott előadók, vállalkozók révén inspiráció, know-how, átadása; tanácsadás, mentorálás.

2. Egyetemi kutatások kommercializálása

Az egyetemnek van egy dedikált szervezete (University of Cambridge Enterprise), mely az egyetemről kijövő kutatások üzleti realizálódását segíti elő. Ami érdekessége ennek a cégnek, hogy konzultációs és technológia transzferrel kapcsolatos szolgáltatásokon kívül pénzbeli támogatást is képes nyújtani (erre a célra elkülönített magvető alap). Az egyetemi vállalat ezen túlmenően egyfajta kétirányú közvetítő funkciót is ellát az egyetem (IP ügyek, tanácsadás, finanszírozás) és az ipar (licenszing, tanácsadás, befektetési lehetőségek, egyetem által fejlesztett reagensek, labor termékek értékesítése) között.

3. MPhil programok és belső képzések

A Judge Business School által kínált üzleti MPhil programok olyan MSc-s szint utáni, de még PhD-s szint előtti programok, melyek áthidalják az „ez még kevés, az meg már túl sok" problémakörét. Így olyan átmeneti képzést nyújtanak, mely időben kellően rövid, ugyanakkor megfelelően gyakorlatias és specializált.

Professional Practice MPhil kategóriában a nem üzleti végzettségüeknek nyújtanak üzleti/vállalkozásindítási know-how-t, míg Research MPhil kategóriában leendő üzleti $\mathrm{PhD}$-soknak adnak szakirányú továbbképzést, gyakorlatot. Ez egyúttal része egy igen erös szelekciós folyamatnak is, mely a PhD képzésben való bennmaradáshoz szükséges (a PhD elsö éve csak próbaidö).

Az Iskola ezzel igen jól ráérzett arra a jelenségre, hogy az egyetemről frissen kikerülő hallgatók nagy részének még szüksége van olyan interdiszciplináris vagy - PhD esetében - átmeneti képzésre, mely segít nekik eligazodni, és hatékony karrierépítési stratégiát követni mind szakmai, mind doktori előmenetelükben. 
Az egyetem által kínált belső képzések pedig afféle tudományterületek közötti továbbképző programok (mérnöki, tudományos, részben üzleti pálya). Ezek nagyban segítik, hogy az egyetemi képzések a lehető legjobban idomulnak az ipar által támasztott munkaerőpiaci elvárásokhoz. A mai világban már nem csak az jelenti a versenyelőnyt, hogy ki mennyire jeleskedik szakmailag; hanem az is, hogy hogyan tudja az illető hivatását gazdasági, üzleti keretek között újragondolni, vállalati kontextusba építeni.

4. Soft skill-ek erösítése

Nem csak ennek az egyetemnek a sajátja, inkább afféle tendencia a vállalkozói oktatásban az úgynevezett soft skill-ek fejlesztése. E kifejezés alatt föleg az érzelmi intelligenciához köthető kvalitásokat értjük: kommunikációs készség; stílus (közvetlenség, megnyerő fellépés); optimizmus; segítőkészség; kooperációs hajlam; stb. E készségek nemcsak kiegészítik, de „tálalják és el is adják” a hard skill-eket (szaktudás, tapasztalat, végzettség - mindazok a formai követelmények, amelyek egy pozíció betöltéséhez szükségesek).

Tekintve, hogy jelen világunkban egy hard felől soft irányú gazdasági és társadalmi átalakulás megy végbe, e képességek a későbbiekben valószínűleg még nagyobb szerepet kapnak.

\section{ESADE Business School}

1958-ban alapított magántulajdonú üzleti és jogi egyetem ${ }^{23}$. Székhelye eredetileg Barcelonában, Spanyolországban található, de vannak kampuszai Madridban és Buenos Airesben is. Rangsorolását tekintve 8. helyet ért el a Financial Times, 5. helyet a Bloomberg Businessweek, szintén 5. helyet a The Economist és 14. helyet a Forbes listáján.

\section{MÓDSZEREK:}

- Tantermen kívüli, szakkör jellegü MBA specializációk

- Nemzetközi hallgatói környezet

\footnotetext{
${ }^{23}$ Az IE Business School és az ESADE Business School ugyanazt a hirdetés elhelyezési stratégiát követi, azaz a honlapjukon történő vizsgálódás után más honlapok bannerjein a legtöbb esetben az említett iskolák hirdetései jelennek meg.
} 
- 3-4 hónapos csereprogramok (partneri viszony a világ legnevesebb üzleti egyetemeivel)

- Leadership Assessment and Development Programme (LEAD): Azon túl, hogy megtanítják, hogyan kell létrehozni és müködtetni egy vállalkozást (hard skills), kiemelt figyelmet fordítanak a vállalkozó kulcsfontosságú, személyes kvalitásaira is (soft skills).

- Action Learning Consulting Programme (ALCP): Konzultációs gyakorlat az egyetem inkubátorházával együttmüködve (tanácsadás a portfolió cégeknek).

- Saját elektronikus tudásközpont üzemeltetése (ESADE Knowledge)

\section{SZAKOK:}

- Alap: BBA (Bachelor of Business Administration): 4 éves BBA képzés. A tanterv fő elemei: esettanulmányok, üzleti szimulációk, kötelező szakmai gyakorlat.

\section{- Mester:}

○ MBA: 12-15-18 hónapos MBA képzés. Az első szemeszter alapozó gazdasági, politikai ismereteket ad; a második a menedzsment hatáskörébe tartozó döntéseket tekinti át; a harmadikban a hallgatók megismerkednek a stratégia-kivitelezéssel és növekedés-menedzsmenttel; míg a negyedikben tetszés szerint választhatnak specializációt. Nevezetesen: International Management (marketing, pénzügy, operatív müködés, HR, stb.); Global Strategy (vállalati stratégia, üzleti modellek, globális kontextus); Leadership (interkulturális menedzsment, komplexitás és adaptáció, tárgyalás, kommunikáció) Zárásként az MBA-t három módon lehet befejezni: Üzleti terv írásával, Diplomamunka készítésével, illetve egy Konzultációs projekten keresztül.

○ Executive MBA (EMBA): 16 hónapos levelező képzés, elsősorban nagyobb tapasztalttal rendelkező menedzsereknek, vezetőknek. Az IE Business School gyakorlatához hasonlóan a résztvevők elvégezhetnek egy Üzletfejlesztési projektet, ahol lehetőségük van, hogy kockázat nélkül kísérletezzenek ki egy a cégükre releváns stratégiát, vagy megvizsgálják egy üzleti ötletük életképességét

○ Global Executive MBA (GEMBA): A Georgetown University és az ESADE közös, 14 hónapos levelező képzése. A 6 darab 2-hetes modul keretében a világ 4 kontinensén, 5 országában történik az oktatás. (Majd 150000 \$-os tandijával az egyik legdrágább program a tanulmányban.) 
○ Master in Innovation and Entrepreneurship: 1 éves, kifejezetten high-tech vállalkozások indítására felkészítő képzés. Tanterve nem annyira az általános üzleti specialitásokra megy rá (mint egy MBA), sokkal inkább az eszközök, erőforrások gyakorlati felhasználására. Igen funkcióközpontú képzés.

- Igazgatói/Felsővezetői képzések: A többi egyetemhez hasonlóan az ESADE is ajánl nyílt és személyre szabott képzéseket is.

\section{FONTOSABB KURZUSOK:}

- Kvantitatív módszerek a menedzsment szolgálatában (Quantitative Methods)

- Professzionális vezetés (Professional Coaching)

- Milyen növekedési stratégia illik a vállalkozásomhoz? (Managing Business Opportunities)

- Marketing StratUpoknak (Marketing for start-ups)

- A szellemi tulajdonvédelem kérdései (Dealing with IPR)

- Hogyan mérhető az innováció? (Measuring Innovation)

- A lehetőség felfedezése: technológia és piacok (Exploring the Opportunity: Technology \& Markets)

- Nyílt innováció és nagyvállalati vállalkozástan (Open Innovation and Corporate Entrepreneurship)

- Üzleti stratégiák: a $\mathbf{K}+\mathbf{F}$ rés áthidalása (Business strategies to bridge the gap between R\&D and successful business)

\section{STRATÉGIA:}

1. EsadeCreapolis: Innovációs inkubátor üzemeltetése

Az egyetem helyi pénzintézetekkel, az állami és magánszféra szereplöivel karöltve olyan Open Innovation ${ }^{24}$ alapokra épülő inkubátorházat hozott létre, mely egyesíti az egyetemről származó kutatásokat és know-how-t a kívülröl érkező tudással és tapasztalattal. Így olyan támogató környezetet hozva létre, mely előnyöket jelent a belülről és kívülről érkező résztvevőknek egyaránt.

\footnotetext{
${ }^{24}$ Az innováció olyan megközelítése, mely egyaránt él a vállalkozáson belülről, illetve a vállalkozáson kívülről származó újító ötletekkel, módszerekkel. Így egy innovációs közösség tagjai kölcsönösen járulnak hozzá és élnek is a megosztott, kollektív tudás lehetőségeivel. Lásd például Procter \& Gamble.
} 


\section{ESADE Knowledge}

Saját elektronikus tudásközpont üzemeltetése. Ez áttekinthetővé és könnyen hozzáférhetővé tesz az egyetemről származó publikációkat, tanulmányokat. Ezzel is növelve az Üzleti Iskola reputációját, médiavisszhangját.

3. Tantermen kívüli, szakkör jellegű MBA specializációk

Ezek a tulajdonképpeni specializációk nem hagyományos tanrendbe épített kurzusokként, hanem afféle egyesületekként/közösségekként fejtik ki hatásukat. Öt ilyen specializációból választhatnak az MBA-s hallgatók (Entrepreneurship \& Innovation; Finance; International Family Business; Latin America; Marketing). Ezek mindegyike a külön kis végzettségnek megfelelö, igazoló dokumentumot is ad.

Ez az oktatási módszer szemináriumok, műhelymunkák, kerekasztal beszélgetések, mentorálás, áthallgatások, szakmai gyakorlatok formájában gazdagítja a diákok tudását, tapasztalatát. Ami igazán lényeges és újító ebben a gyakorlatban az az, hogy a hallgatók egyfajta kötetlenebb közösség tagjaiként értelmezhetik magukat. Ez a megközelítés hasonlít az amerikai egyetemek „fraternity \& sorority” közösségeihez, azonban annál sokkal professzionálisabbak, kifejezetten karrierépítési célokat szolgálnak.

\section{HEC Paris}

1881-ben alapított üzleti elitiskola. Székhelye Párizsban, Franciaországban található. Rangsorolásban 2. helyet ért el a The Economist, 7. helyet a Financial Times, 9. helyet a Bloomberg Businessweek és 15. helyet a Forbes listáján.

\section{MódSZEREK:}

- Képzéstől független, kiegészítő, iparági oklevelek

- Vezetői kvalitások (soft skills) fejlesztése

- Rugalmasan formálható képzéskialakítás.

- Extrák a közép- és felsővezetőknek nyújtott képzések terén.

- Számítógépes üzleti szimuláció

\section{SzAKOK:}


○ Master in Management (MiM): 3 éves menedzsment képzés. A program érdekessége, hogy az első és a harmadik év között (tényleges oktatás), a második évet a hallgatóknak kötelező jelleggel, szakmai gyakorlattal kell tölteniük. Ez segíti a gyakorlati megmerítkezést, és szofisztikáltabb karrieraspirációk kialakulását.

○ MSc-k: Sokféle, változatos program, főként menedzsment, pénzügy, marketing területekről.

○ MBA: 16 hónapos MBA képzés, elérhető nappali és levelező változatban is.Az első év alapozásról szól, a második egy nagyon rugalmas önálló képzéskialakításról. Ennek keretében a hallgató nemcsak szakirányáról és szabadon választható kurzusairól dönt, de dönthet úgyis, hogy szabadon választhatók helyett inkább részt vesz egy nemzetközi csereprogramban, vagy érdeklödésének megfelelö évközi szakmai gyakorlaton egy vállalatnál. A második év innovatív képzési ösvényei: szabadon választhatók/szakmai gyakorlat/nemzetközi csereprogram + szakosodás/nemzetközi csereprogram. Érdemes megemlíteni még, hogy vállalkozás szakirányon (specializáció) a szakosodás nemcsak kurzusok formájában nyilvánul meg; hanem csoportos tevékenységek, mühelymunkák, mentoráló projektek által a hallgatók ténylegesen is bekerülnek egy vállalkozói „tanulókörbe”. Itt a tanulást „learning by doing” tapasztalatként kell értelmezni.

○ Executive MBA (EMBA): 13-16 hónapos EMBA képzés, a Babsonnal közösen fejlesztve. Ahogyan alább, az iparági okleveleket részletező szakaszban látni fogjuk, az egyetemnek igen szoros összefonódás van az iparral. Ennek köszönhetően az ott említésre kerülő ipari know-how-t az EMBA esetében is kamatoztatja az Iskola: hasonló „résspecializációk” (Luxus szektor, Repülés, Feltörekvő gazdaságok üzleti lehetőségei, stb.). Az IE és az ESADE Üzleti Iskolákhoz hasonlóan ezt a képzést is egy Capstone projekt zárja. Lényegében egy üzleti kihívás elemzéséről, majd egy szakértőkből álló zsűri előtt a diplomamunka megvédéséről van szó. A képzés érdekessége még, ahogy az innovációt megközelíti: az innováció nem a cég briliáns elméi által, heroikusan kivívott 
végső diadal, mely egyszer s mindenkorra megoldja a versenyképesség problémáját (bár meglehet, hogy ilyennek látszik). Valójában az innovációnak mint a növekedés fő motorjának - ugyanúgy kellene működnie, mint bármely más üzleti funkciónak (termelés, marketing, pénzügy, adminisztráció, stb.). Egyfelől itt az időbeni folyamatosságra gondolunk (nem lehet leülni és sokáig veregetni a vállunk). Másik oldalról (és ezt kicsit nehezebb kezelni) - diffúz jelenlétéből adódóan (értsd: minden egyes funkciónak, folyamatnak része, nem lehet elkülönült osztályként tekinteni) - az innovációnak a többi funkcióhoz képest komplexebb erőforrásokra van szüksége (kreativitás, szabadság, rugalmasság, születő technológiák és módszerek, rutin, optimalizálás). E források akár vezetői, akár beosztotti oldalról érkeznek, esszenciájuk közös: vállalkozói gondolkodásmód és innovációs képesség. Ezeket igyekszik fejleszteni a program vállalkozói és innovációs specializációja.

○ TRIUM Global EMBA: 17 hónapos GEMBA program. Az oktatás Londonban, New Yorkban, Párizsban, valamint egy-két feltörekvő gazdaságú országban (pl.: Kína, India) történik.

- Igazgatói/Felsővezetői képzések: A korábbi példákhoz hasonlóan itt is megtalálhatók a nyílt és személyre szabott programok.

\section{FONTOSABB KURZUSOK:}

- Növekedési stratégia korai fejlődési fázisú cégeknek (Development Strategy for Early Stage Companies)

- A szellemi tulajdon jogi kérdései (Intellectual Property Law)

- Befektetés tudományos és technológiai újításokba (Investing in Science \& Technology)

- Technológiai fejlődés: Hogyan és milyen irányba változtatja a piaci lehetőségeket? Miként gyakorolhat erre hatást egy vállalkozás? (Technology Evolution)

- Jó ember a jó helyen. Hogyan? (People and Business Performance)

- A stratégiatervezés új dimenziója: mit várhatunk a jövőben? (Futures Analysis)

- Szolgáltatások kiszervezése (Issues in Services Offshoring)

- A befolyásolás fegyvertára (Weapons of Influence) 


\section{STRATÉGIA:}

1. Képzésfüggetlen, kiegészítő, iparági oklevelek

E szakirányú képzéseket 2009-től kezdte bevezetni az egyetem. Voltaképpen azoknak a hallgatóknak szól, akik MiM, MSc, vagy MBA programjuk vége felé haladva igényt tartanak valamilyen iparági specializációra. Ami korábban csak iparspecifikus, szabadon választott kurzusok felvételét és teljesítését jelentette, mára már oklevelet adó képesítéssé vált.

Az ilyen típusú oklevelek létrejötte elsősorban ipari (munkáltatói) nyomáshoz köthető. Megjelent az ipar felől egy igény, amire az egyetem válaszolt. Így bottom-up megközelítéssel, keresleti oldalról történt képzésfejlesztés. Ezt támasztja alá az is, hogy a - 100 óra munkát: üzleti projekteket, „terepi munkát” magukba foglaló szakirányú képesítések elsősorban cégek által szponzoráltak. Ha kicsit beleolvasunk az egyes oklevelek programszerkezetébe, láthatóvá válik, hogy ez egy nagyon erős, és meglehetősen hatásos ipari-egyetemi összefonódás (Digital Innovation for Business, Energy and Finance, Innovation Management in Aviation \& Aerospace, Luxury, Social Business).

2. Vezetői kvalitások (soft skills) fejlesztése

Az egyetem képzéseibe horizontális pillérként van beépítve a soft skill-ek fejlesztése. Ez olyan tantermen kívüli rendezvényeken kerül átadásra, mint:

- $\quad$ CEO series (vezérigazgatói beszédek)

- $\quad$ MBA Tournament (15 nemzetközi iskola MBA hallgatóinak sporttornája)

- Off-Campus Leadership Seminar (katonai csapatépítés terepen)

- $\quad$ Student-Run Conferences (hallgatók által szervezett és tartott konferencia)

- $\quad$ TEC on Campus (karrierfejlesztési, életvezetési kiscsoportos beszélgetés vezetőkkel, igazgatókkal) 


\section{University of Oxford - Saïd Business School}

Egy igen fiatal, 1996-ban alapított Üzleti Iskoláról van szó. Az Iskola a University of Oxford tagintézménye, székhelye Oxfordban, az Egyesült Királyságban található. Fiatal kora ellenére 4. helyet ért el a Bloomberg Businessweek, 6. helyet a Forbes, 9. helyet a Financial Times és 17. helyet a The Economist és listáján.

\section{MóDSZEREK:}

- Támogató vállalkozói környezet (lásd: Startégia)

- Gyakorlatias, vállalkozóközpontú képzés (lásd: Startégia)

- Területre fókuszált képzések: Oxford Diplomas

- Érdeklődési területre szűkíthető programportfolió: pl. ha vállalkozástannal kapcsolatos képzést keresünk, erre szűkítve csak azok a programok jelennek meg, amelyek ilyen tartalommal bírnak.

- Tanterven kívüli interdiszciplináris; vállalkozói előadássorozatok: Building a Business, Lean LaunchPad, Oxford at Saïd, Science Innovation Plus

\section{SzAKOK:}

- Mester:

○ MSc in Major Programme Management: 2 éves levelező menedzsment képzés.

○ MBA: 1 éves nappali képzés, sok esettanulmány, csapatmunka és szimuláció jellemzi. Az elméleti oktatás mellett kiemelt szerepet kap a gyakorlat: vállalkozói, konzultációs és GOTO (Global Opportunities and Threats Oxford) projektek.

○ Executive MBA (EMBA): 21 hónapos, levelező EMBA képzés. Kiemelt figyelem a személyes vezetői készségek (soft skills) fejlesztésén. A vállalkozói, GOTO projektek, ahogy az MBA esetében, itt is jelen vannak; ezen túl - mivel az egyes modulok különböző országokban vannak megtartva - szerepet kap a globális kontextus.

○ Oxford Diplomas: Olyan 1 éves képzések ezek, melyek az egyetem általánosMBA programjának speciális területeire fókuszálnak. (Darabokra szedték az MBA-t, majd annak bizonyos részeiből egyedi, levelezőn végezhető képzéseket hoztak létre.) Ez azért jó, mert ha valaki karrierje folytán már specializálva van 
egy irányba, nem kell végighallgatnia az egész MBA-s tantervet, viszont sokkal jobban elmerülhet saját szakterületében. Ennek megfelelően 4 ilyen diplomát ajánl az egyetem: Financial Strategy, Strategy \& Innovation, Organisational Leadership, Global Business.

- Igazgatói/Felsővezetői képzések: Hasonlóan a korábbi egyetemekhez, a Said-nél is megtalálhatók mind a nyílt, mind a személyre szabott programok.

\section{FONTOSABB KURZUSOK:}

- Adatelemzés, döntéshozatal (Decision and data analytics)

- Viselkedési pénzügy: az objektív racionalitáson túl (Behavioural finance)

- Eszközgazdálkodás (Asset management)

- Befektetési esettanulmányok (Cases in Finance \& Investment)

- A kultúra globális piacokra gyakorolt hatása (Culture \& global markets)

- A dizájn innovációs szerepe (Design for innovation \& change)

- Hogyan építsünk ki erős, pozitív reputációt? (Reputation \& leadership)

- Magánszféra - újragondolva (Rethinking business)

- Társadalmi célú vállalkozások (Social entrepreneurship)

- Stratégiai kivitelezés (Strategy implementation)

- A komplexitás kezelése (Managing complexity)

\section{STRATÉGIA:}

1. Gyakorlatias, vállalkozóközpontú képzés (MBA)

E megközelítés alatt olyan elméleti oktatáson kívüli, egyéni és csapatmunkára építő projekteket értünk, melyek segítenek a hallgatóknak vállalkozói készségek, tapasztalatok megszerzésben. Ezek a következők:

- Vállalkozói projektek: Egyéni feladat, amelynek célja üzleti terv írása és bemutatása befektetők, tantestületi tagok előtt. Kitűnő lehetőséget nyújt saját üzleti ötlet megvalósítására.

- Konzultációs projektek: Csapatmunka. Tanácsadói szolgáltatás külsős cégeknek, alapítványoknak, amely két szempontból is előnyös: egyfelől ha régóta szeretnénk bekerülni egy álommunkahelyre, ez remek alkalom, hogy 
választott cégünkhöz dolgozzunk be tanácsadóként; másfelől amennyiben a vállalkozói projekt során saját ötletet dolgoztunk ki, a konzultációs projekt jól használható a megvalósítás következő fázisaként.

- GOTO projektek: A Global Opportunities and Threats Oxford olyan kezdeményezés, mely harmadik világbeli, valamint globálisan az egész társadalmat érintő problémákra kíván alternatívákat találni. Ezt egy olyan online felületen valósítják meg, mely lehetővé teszi a közösségi szintü problémamegoldást (anyagokat lehet feltölteni, hivatkozni egymásra, kommentálni, társalgást folytatni). A GOTO valójában egyfajta „idea pool”, mely a jövőben induló, társadalmi célú vállalkozásokat fog kiszolgálni.

2. Támogató vállalkozói környezet megteremtése

Az egyetem számos olyan lépést tett, mely elősegítette, hogy Oxfordban pezsgő vállalkozói légkör alakuljon ki. Egyik ilyen volt a Vállalkozói központ létrehozása, mely szemináriumokat, networking rendezvényeket tart; versenyeket szervez; különféle vállalkozói képzéseket, támogatást nyújt. E sikerekben (indulástól számítva több mint 150 megalapított cég; 22000 résztvevö a kurzusokon, rendezvényeken; 2,5 millió letöltés - szabadon hozzáférhetö elöadások, hanganyagok) valószínüleg az is közrejátszik, hogy az egyetem megfelelően tudja tolmácsolni a menedzsmenti és vállalkozói létforma közti különbséget. Így - talán a nagyobb társadalmi elfogadottság következtében - több emberhez tudnak eljutni az inspiráló sikertörténetek.

A másik ilyen szervezet az Oxford Entrepreneurs. Ez egy a hallgatókat, az alumnit és külső szereplöket is tömörítő fórum, mely 10000 tagjával valószínűleg méltán nevezheti magát Európa legnagyobb hallgatói vállalkozói közösségének. Kapnak támogatást az egyetem Vállalkozói központjától, de formálisan függetlenek tőle. Ők hallgatói oldalról közelítik meg a fiatal vállalkozók szükségleteit, és ennek megfelelően támogatják őket: inspiráció, oktatás, networking, versenyek, tanácsadás.

Végül, de nem utolsó sorban pedig mindkét szervezet szoros kapcsolatot ápol az egyetem technológia transzfer társaságával (Isis Innovation). 


\section{SDA Bocconi School of Management}

1971-ben alapított Üzleti Iskola, a Bocconi University tagszervezete. Székhelye Milánóban, Olaszországban található. Rangsorolásban 3. helyet ért el a Forbes, 10. helyet a Bloomberg Businessweek és 14. helyet a The Economist valamint a Financial Times listáján.

\section{MÓDSZEREK:}

- Kutatással is fejleszthetők a vállalkozói ismeretek: irodalmazás, cikkírás Research papers. Ezt követően a tanulság levonása, a hasznosítható tudás beépítése a vállalkozói repertoárba.

- Széles képzésportfolió (főleg menedzsment mesterképzések, és vállalati ügyfelekre szabott programok tekintetében).

- Széles kurzusválaszték.

\section{SzAKOK:}

- Mester:

○ MBA: 12 hónapos képzés. A program néhány, szorgalmi időszak előtti ismétlő kurzussal kezdődik (ezek nem mindenkinek kötelezők). A képzés alapozó tárgyai a közgazdaságtan, pénzügy és vezetés köré szerveződnek. Ezt követik a nyári projektek (egyéni szakmai gyakorlat egy cégnél/konzultációs csapatmunka/üzleti terv készítése vállalkozási céllal/irodalmazás, kutatás). Végül pedig, a képzés lezárásaként a hallgatók többsége specializációt választ (pénzügy, marketing, vállalkozástan ösvények), míg a szerencsés keveseknek lehetősége nyílik nemzetközi csereprogramban részt venni.

○ Executive MBA (EMBA): 21 hónapos, levelező EMBA képzés.

○ Global Executive MBA (GEMBA): 20 hónapos, levelező GEMBA képzés. Az egyes modulok Európában, az USA-ban, Brazíliában, Kínában hallgathatók. Felépítése az MBA-hez hasonló: előzetes kurzusok, alapozó tárgyak, haladó szintü tárgyak, szabadon választhatók.

- Egyéb: Iparág- és területspecifikus menedzsmentképzések (pl. Divat, Élelmiszeripar, Egészségügy; Public management, Értékesítés és marketing).

- Igazgatói/Felsővezetői képzések: A korábbi egyetemekhez hasonlóan az SDA-nál is megtalálhatók a nyílt, valamint vállalati igényekre szabott képzések. Nyílt képzések 
esetén kiemelendő a területek figyelemfelkeltő témája (pl.: Structured Products: Risks, Rewards, Valuation; New Technologies in Retail; Internet, Social Media and Mobile for Corporate and Marketing Communication; The Marketing in You). Míg vállalati igényekre szabott képzések esetén a nagy specializációérdemel említést (külön kategóriába sorolják a vállalati, a pénzintézeti és non-profit szervezeteket). Ennek megfelelően az egyes csoportok különböző szolgáltatásokhoz juthatnak.

FONTOSABB KURZUSOK:

- Közgazdaságtan menedzsereknek (Managerial Economics)

- Állami és magánszektorbeli kapcsolatok (Business Government Relationship)

- Marketing kvantitatív megközelítésben (Search \& Mine: a Quantitative Approach to Marketing)

- Vállalkozás és üzleti tervezés (Entrepreneurship and Business Planning)

- Brand menedzsment (Brand Management)

- Változás: szervezeti megújulási stratégiák (Change and Organizational Renewal Strategies)

- Fúzió és felvásárlás pénzügyi szempontból (M\&A Financial Perspective)

- Fúzió és felvásárlás a vezetés szempontjából (M\&A Management Perspective)

- Értékesítés-menedzsment (Sales Force Management)

- Szervezetépítés, csoportdinamika: hogyan tegyük hatékonyabbá a csoportfolyamatokat? (Managing People and Designing Organizations)

\section{STRATÉGIA:}

A Bocconi erősségeként leginkább didaktikus felépítésű képzései, valamint széles kurzuskínálata említhető. A többi egyetemtől eltérően úgy tűnik, nem arra pozícionálták magukat, hogy általános képzéseiket „színes-szagos” kurzusokkal tüzdeljék meg (mint a Judge Business School). Ehelyett sok és változatos programot kínálnak, melyeket ugyancsak sokféle kurzussal töltöttek fel. E kurzusok mindegyike egyedi (szak/szektorspecifikus), ugyanakkor mindben megvan az eredendő, alkalmazott üzleti szemlélet. 